\title{
A UNIVERSIDADE PÚBLICA EM CONTEXTO DE URBANIZAÇÃO PERIFÉRICA: AÇÕES DO CAMPUS DIADEMA SOBRE DESENVOLVIMENTO URBANO E REGIONAL
}

Dissertação apresentada ao Programa de PósGraduação em Arquitetura e Urbanismo da Universidade de São Paulo para obtenção do título de Mestre em Ciências.

Nível: Mestrado

Área de Concentração:

Planejamento urbano e regional

Linha de Pesquisa: Políticas públicas urbanas

Orientadora:

Prof $^{\mathrm{a}}$. Dra ${ }^{\mathrm{a}}$. Maria de Lourdes Zuquim 
Autorizo a reprodução e divulgação total ou parcial deste trabalho, por qualquer meio convencional ou eletrônico, para fins de estudo e pesquisa, desde que citada a fonte.

Catalogação na Publicação

Serviço Técnico de Biblioteca

Faculdade de Arquitetura e Urbanismo da Universidade de São Paulo

Sartori, Alex de Oliveira

Universidade pública em contexto de urbanização

periférica: ações do campus Diadema para o desenvolvimento urbano e regional. / Alex de Oliveira Sartori; orientadora Maria de Lourdes Zuquim. - São Paulo, 2019.

$159 \mathrm{f}$.

Dissertação (Mestrado) - Faculdade de Arquitetura e Urbanismo da Universidade de São Paulo. Área de

concentração: Planejamento Urbano e Regional.

1. Universidade Pública. 2. Desenvolvimento Urbano. 3. Diadema $(\mathrm{sp})$. 4. Políticas Públicas. I. Zuquim, Maria de Lourdes, orient. II. Título.

Elaborada eletronicamente através do formulário disponível em: $<$ http://www.fau.usp.br/fichacatalografica/> 
Nome: SARTORI, Alex de Oliveira

Título: A universidade pública em contexto de urbanização periférica: ações do campusDiadema sobre desenvolvimento urbano e regional

Dissertação apresentada à Faculdade de Arquitetura e Urbanismo da Universidade de São Paulo para a obtenção do título de Mestre em Ciências.

Aprovado em:

Banca Examinadora

$\operatorname{Prof}(a) . \operatorname{Dr}(a)$.

Instituição:

Julgamento:

Prof(a). Dr(a).

Instituição:

Julgamento:

$\operatorname{Prof}(\mathrm{a}) . \operatorname{Dr}(\mathrm{a})$.

Instituição:

Julgamento: 


\section{AGRADECIMENTOS}

Antes de tudo, agradeço à minha orientadora, Maria de Lourdes Zuquim, por ter acreditado e apostado nesta pesquisa. Por ter me orientado nesse percurso e ter possibilitado que o projeto amadurecesse até se tornar esta dissertação. Por ter me acompanhado durante todos esses anos, desde a graduação.

Agradeço à Universidade de São Paulo e à Faculdade de Arquitetura e Urbanismo por mais esta oportunidade que sei tratar-se de um imenso privilégio e, por isso, uma enorme responsabilidade e profundo compromisso.

À Universidade Federal de São Paulo e, em especial, ao campus Diadema por ter me dado todas as condições, enquanto técnico administrativo, que me permitissem realizar esta pesquisa. Também por todo a ajuda que recebi enquanto pesquisador.

Aos colegas técnicos administrativos e docentes do campus por toda a colaboração que prestaram para a realização desta pesquisa.

Um carinhoso agradecimento à Sacha Senger, pela motivação e companhia no início dessa jornada.

Agradeço também à minha família, sobretudo aos meus pais, por tudo o que fizeram, fazem e abdicaram para que eu pudesse trilhar este caminho.

Por fim, um especial agradecimento a Felippe Rodrigues e a Melina Sternberg, por todo o carinho e apoio ao longo do processo. 


\section{RESUMO}

A pesquisa analisa as ações do campus Diadema da Unifesp que se enquadram sob a ótica do desenvolvimento urbano e regional. A pesquisa destaca a importância histórica conferida às universidades para os processos de desenvolvimento urbano e regional que ainda foi pouco avaliada quanto à expansão universitária entre 2003 e 2010, e menos ainda no campo da arquitetura e do urbanismo. O ponto de partida foi as pesquisas correlatas em diversas áreas do conhecimento que avaliam e defendem as universidades como motrizes de desenvolvimento urbano e regional, sobretudo do ponto de vista do impacto econômico e urbano que a instalação de uma universidade ou campus pode causar sobre o espaço urbano. Procurou-se realizar um diálogo direto entre esta pesquisa e as demais consultadas a fim de que se pudesse levantar semelhanças e diferenças entre os estudos de casos realizados em diversas situações por todo o território brasileiro. Para isso, se examinou as políticas públicas de expansão do ensino superior e sua relação com outras políticas, como de desenvolvimento regional, de desenvolvimento urbano e de ciência, tecnologia e inovação. No mesmo sentido, optou-se por um breve debate sobre os conceitos de desenvolvimento, desenvolvimento urbano e desenvolvimento regional que pudessem ampliar a compreensão dos processos e indicar de que formas as universidades são parte deles. Na sequência, procurou-se elencar dados históricos e sociais que caracterizam o município de Diadema, considerando sua inserção regional, a fim de lançar luz sobre o contexto sobre o qual o campus Diadema foi inserido e de indicar quais importâncias ele pode ter sobre diversos aspectos do desenvolvimento urbano e regional. Para descrever as ações do campus que se relacionam com o desenvolvimento urbano e regional, se fez o levantamento histórico do campus que trouxe à tona as circunstâncias e arranjos sociais e políticos que o tornaram possível. Também se levantou e interpretou as parcerias que o campus estabelece com a comunidade externa, além da própria descrição do campus e das suas atividades de ensino. Outra forma de levantamento de dados foram enquetes aplicadas com docentes e técnicos que apontaram para a relação deles com o espaço urbano. De forma geral, confirmou-se que os impactos urbanos são de pouca relevância, sobretudo comparado a outros estudos realizados em municípios de pequeno e médio portes. Por outro lado, se questionou a real capacidade de incidência das ações do campus sobre o desenvolvimento urbano e regional dadas as condições e características da política pública de desenvolvimento regional, da relação da indústria com a pesquisa e a inovação e da organização política do país.

Palavras-chave: Universidade pública; Desenvolvimento urbano, Diadema (SP); Políticas públicas. 


\section{ABSTRACT}

This research analises the acting of de Diadema's campus of the Federal University of São Paulo - Unifesp - under the urban and regional development point of view. It's underlined de historical importance that was given to the universities for the urban and regional development, wich has not been enough evaluated about the expansion of the federal universities between 2003 and 2010, and still less in architectural sciencies. This study start point were some related researchs of variated standpoints, wich believes that universities are motives of the urban and regional development, especially from angle of economic and urban impacts the settlement of the universities may cause in urban space. There was a intention of establishing a dialog between this and other consulted studies for making possible to define similarities and differences among some situations in Brazil. For that, it had been examinated the public policies of expansion of federal universities and its relation to others policies, as the one of regional development, urban development, and those of sciencies, tecnology and inovation. In the same meaning, it has been chosen a shot debate abou the concepts of development, urban development and regional development that could make bigger the comprehension of those processes and show in wich ways universities can be part of. In sequence, the historical and social data were listed for characterizing Diadema, including it's regional context towards lightening the situation in wich Diadema's campus was stablished and indicate wich importances it can have over lots aspects of urban and regional development. It also was done the campus historical research, wich brought to light the circumstances and social arrangements that made it possible. Besides that, were found and interpretated the partnerships the campus settle with companies, industries, governments and public agencies, and was done the description of the campus and its teaching activities. An important data source were surveys done with professor and educational technicians, about their relation to the urban space. In general, it has been confirmed that the urban impacts are low relevant, mainly in comparision to other studies realized in small and médium cities. In another sense, it had been questionated the real capacity and interes of incidence of the campus actions over the urban and regional development, the relation of companies and industry to research and inovation and brazilian political organization.

Key-words: public university; Urban development, Diadema; public policy. 


\section{LISTA DE IMAGENS}

Figura 1 - Vagas na graduação presencial em universidades federais (2003 a 2012). ............22

Figura 2 - Universidades federais criadas por período. .......................................................22

Figura 3 - Total de universidades federais por ano (2003 a 2010). ......................................22

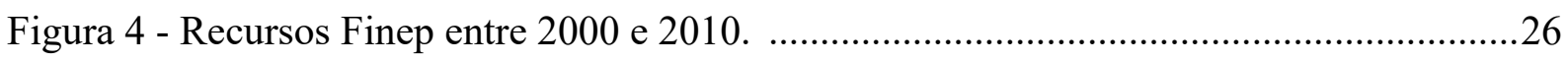

Figura 5 - Número de bolsas por ano do CNPq, Capes e total. ...........................................26

Figura 6 - Evolução das matrículas dos cursos de graduação presenciais e a distância no Brasil,

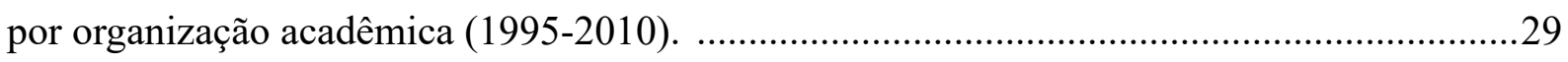

Figura 7 - Localização dos campi das universidades federais em 2002 . ...............................31

Figura 8 - Localização dos campi das universidades federais em 2002. ................................32

Figura 9 - Capitais relacionados às universidades para a promoção do desenvolvimento regional. 53

Figura 10 - Região Metropolitana de São Paulo, divisão municipal. . ....................................59

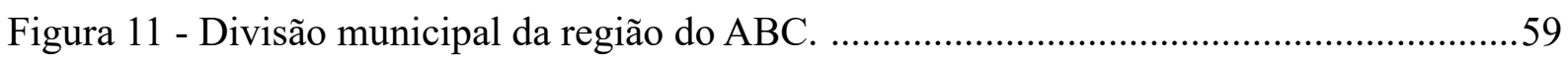

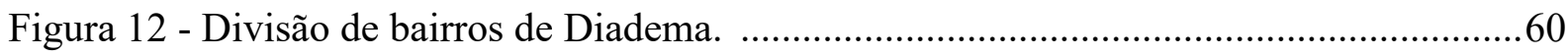

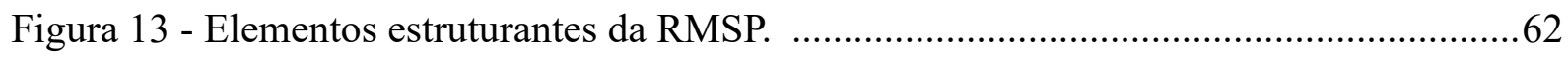

Figura 14 - Porção norte do município de Diadema e arredores em 1958. …….....................63

Figura 15 - Porção norte do município de Diadema e arredores em 2018. ............................64

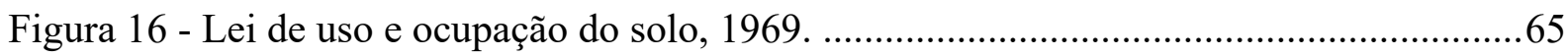

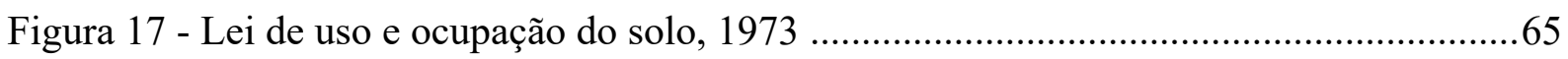

Figura 18 - Percentual dos domicílios particulares permanentes por classes de rendimento nominal mensal docimiliar per capita em 2010 - Dados do universo. ...................................66

Figura 19 - Taxa de homicídios dolosos por 100 mil habitantes em Diadema .......................68

Figura 20 - Óbitos totais e por natureza do óbito em Diadema, por lugar de registro .............68

Figura 21 - Percentual de domicílios particulares ligados à rede regal de esgoto ou pluvial. .69

Figura 22 - Percentual dos domicílios particulares permanentes não ligados à rede geral de esgoto ou pluvial em 2010.

Figura 23 - Percentual dos domicílios particulares permanentes abastecidos pela rede geral de água. $\quad 69$

Figura 24 - Percentual dos domicílios particulares permanentes que tinham energia elétrica por companhia distribuidora em 2010.

Figura 25 - Número e percentual de domicílios permanentes em áreas urbanas com ordenamento regular em relação ao total de domicílios particulares permanentes em Diadema. 
Figura 26 - Percentual dos domicílios particulares permanentes em áreas urbanas com ordenamento regular de Diadema, por características do entorno em 2010.

Figura 27 - Percentual dos domicílios particulares permanentes ligados à rede geral de esgoto ou pluvial nos bairros de Diadema.

Figura 28 - Percentual dos domicílios particulares permanentes abastecidos pela rede geral de água nos bairros de Diadema.

Figura 29 - Evolução do emprego na indústria, comércio e serviços (2002 a abril de 2017). 74

Figura 30 - Valor adicionado bruto por atividade econômica no PIB. .75

Figura 31 - Participação das atividades econômicas no PIB. .75

Figura 32 - Balança comercial de Diadema - 2000 a 2016. 76

Figura 33 - Composição do IDHM de Diadema por Censo. 1991 a 2010. .83

Figura 34 - População de crianças e adolescentes de Diadema que frequentava escola ou creche e percentual em relação à faixa etária, em 2010.

Figura 35 - Percentual da população com quatro ou mais anos que nunca frequentou a escola ou creche, por faixa etária, 2010. 84

Figura 36 - Percentual da população por frequência à escolha ou creche em 2010.

Figura 37 - População de Diadema com 15 anos ou mais sem instrução ou com fundamental incompleto, por faixa etária, 2010.

Figura 38 - Percentual de pessoas com 10 anos ou mais não alfabetizadas por faixa etária, com relação ao total da população.

Figura 39 - Percentual de pessoas de 10 anos ou mais não-alfabetizadas. 86

Figura 40 - Percentual de pessoas de 25 anos ou mais sem instrução ou com fundamental incompleto. 2000 e 2010.

Figura 41 - Figura 40 - Percentual de pessoas de 25 anos ou mais com nível superior. 2000 e 2010. 86

Figura 42 - Percentual da população com 25 anos ou mais por grau de instrução em 2010. ..87

Figura 43 - Porcentagem de estudantes da rede pública com desempenho considerado "aprendizado adequado" na Prova Brasil - Português, 5º ano. 2011, 2013 e 2015. 89

Figura 44 - Porcentagem de estudantes da rede pública com desempenho considerado "aprendizado adequado" na Prova Brasil - Portugues $9^{\circ}$ ano.

Figura 45 - Porcentagem de estudantes da rede pública com desempenho considerado "aprendizado adequado" na Prova Brasil - Matemática $5^{\circ}$ ano.

Figura 46 - Porcentagem de estudantes da rede pública com desempenho considerado "aprendizado adequado" na Prova Brasil - Matemática $9^{\circ}$ ano. 90

Figura 47 - Localização das unidades do campus Diadema.

Figura 48 - Inserção urbana da unidade José de Filippi. 
Figura 49 - Inserção urbana das unidades Florestan Fernandes e Manoel da Nóbrega (oficina mecânica).

Figura 50 - Inserção urbana das unidades Florestan Fernandes e Manoel da Nóbrega (oficina mecânica).

Figura 51 - Unidade José Alencar da Unifesp e divisas com a Uniforja. .95

Figura 52 - Plano de expansão do Campus Diadema. 96

Figura 53 - Municípios de residência dos docentes do campus Diadema. 132

Figura 54 - Opção de docentes por mudarem ou não a residência para trabalhar no campus Diadema, motivos para não terem mudado e, entre os que se mudaram, se optaram por Diadema ou outros municípios.

Figura 55 - Municípios de residência dos docentes do campus Diadema. 133

Figura 56 - Distribuição das residências dos docentes do campus Diadema. 134

Figura 57 - Distribuição das residências dos técnicos do campus Diadema. 134

Figura 58 - Opção de técnicos por mudarem ou não a residência para trabalhar no campus Diadema, motivos para não terem mudado e, entre os que se mudaram, se optaram por Diadema ou outros municípios.

Figura 59 - Meios de transporte de docentes, técnicos e total para deslocamentos entre a residência e o campus Diadema. 136

Figura 60 - Percepção das mudanças no entorno das unidades do campus Diadema por Docentes, Técnicos e Totais 139

Figura 61 - Percepção de docentes quanto a alterações no entorno e fechamento de comércios por unidades agrupadas. 


\section{LISTA DE TABELAS}

Tabela 1 - Vagas no ensino superior público e privado entre 2001 e 2010 e vacância de vagas. Elaboração própria a partir de dados do Censos da Educação Superior (INEP, 2001-2010). .28

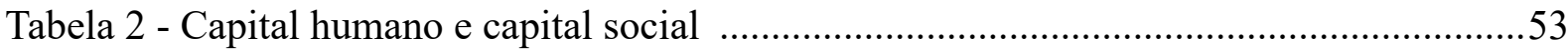

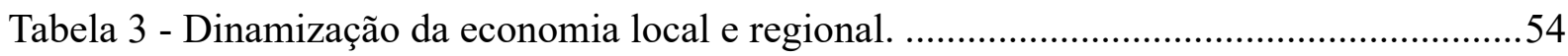

Tabela 4 - Fonte: BRÜNE, 2015a. Elaboração própria de acordo com o original. ...................54

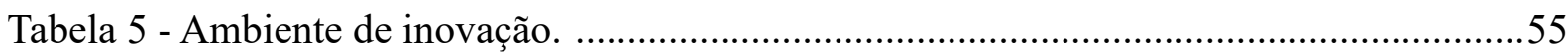

Tabela 6 - Principais empresas que colaboraram com publicações científicas no Brasil de 2011 a 2016, por volume de publicações. .78

Tabela 7 - Universidades brasileiras com maiores volumes de publicações científicas entre 2011 e 2016. 79

Tabela 8 - Serviços e produtos consumidos pelo campus e origem das empresas fornecedoras. 142 


\section{LISTA DE ABREVIATURAS E SIGLAS}

CT\&I - Ciência, Tecnologia e Inovação

CEFET-RJ - Centro Federal de Educação Tecnológica do Rio de Janeiro

CEMIB - Centro Multidisciplinar para Investigação Biológica

CIESP - Centro das Indústrias do Estado de São Paulo

CNPq - Conselho Nacional de Desenvolvimento Científico e Tecnológico

Capes - Coordenação de Aperfeiçoamento de Pessoal de Nível Superior

Emplasa - Empresa Paulista de Planejamento Metropolitano S.A

Enem - Exame Nacional do Ensino Médio

Etec - Escola Técnica Estadual de São Paulo

Fatec - Faculdade de Tecnologia

FHC - Fernando Henrique Cardoso

Finep - Empresa Federal Financiadora de Estudos e Projetos

IBGE - Instituto Brasileiro de Geografia e Estatística

LPC - Licenciatura Plena em Ciências

MPF - Ministério Público Federal

PACTI - Plano de Ação de Ciência, Tecnologia e Inovação para o Desenvolvimento Nacional PDE - Plano de Desenvolvimento da Educação

PNE 2001 - Plano Nacional de Educação (elaborado em 2001)

ProUni- Programa Universidade para Todos

Região do ABC - Região compreendida pelos municípios de Santo André, São Bernardo e São

Caetano, que engloba também Diadema, Mauá, Ribeirão Pires e Rio Grande da Serra

RMSP - Região Metropolitana de São Paulo

Reuni - Programa de Apoio a Planos de Reestruturação e Expansão das Universidades Federais

Sebrae - Serviço Brasileiro de Apoio às Micro e Pequenas Empresas

Senac - Serviço Nacional de Aprendizagem Comercial

Senai - Serviço Nacional de Aprendizagem Industrial

Sesi - Serviço Social da Indústria

Sisu - Sistema de Seleção Unificada

UFABC - Universidade Federal do ABC

UFRGS - Universidade Federal do Rio Grande do Sul

Unifesp - Universidade Federal de São Paulo

Unicamp - Universidade Estadual de Campinas

USP - Universidade de São Paulo 


\section{SUMÁRIO}

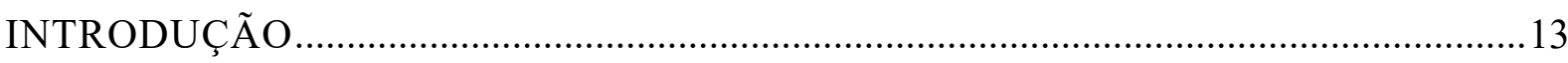

1. POLÍTICAS DE EXPANSÃO DO ENSINO SUPERIOR E O DESENVOLVIMENTO

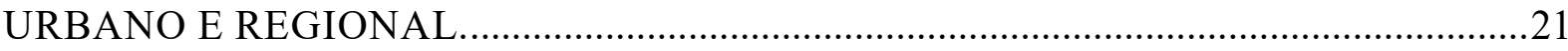

1.1 As políticas de expansão do ensino superior no Brasil entre 2001 e 2010 ..............21

1.2 A relação entre desenvolvimento urbano e regional e universidades ..........................33

1.3 Pesquisas sobre a relação entre expansão das universidades federais e desenvolvimento

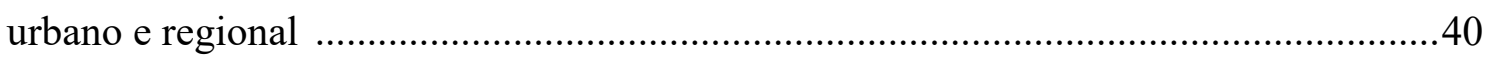

1.4 Elementos e descritores para a análise do campus Diadema …………………….....58

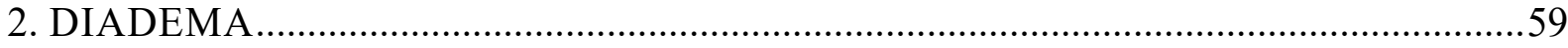

2.1 - A formação do espaço urbano em Diadema. ............................................................60

2.2 - Transformações urbanas recentes em Diadema ……………………………….......73

2.3 - Caracterização social e educacional de Diadema ……………………………........82

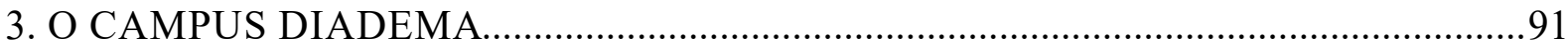

3.1 Histórico do Campus Diadema: ...............................................................................97

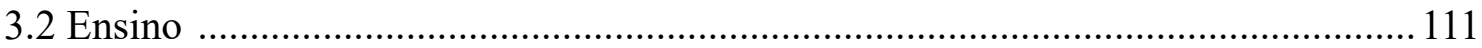

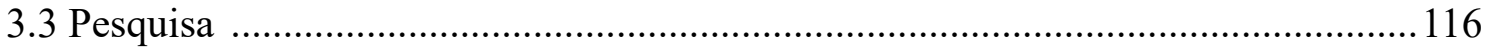

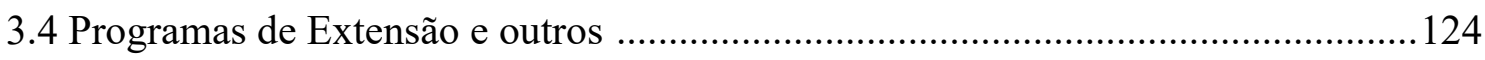

3.5 - As relações com o espaço urbano ......................................................................130

CONSIDERAÇÕES FINAIS ....................................................................................145

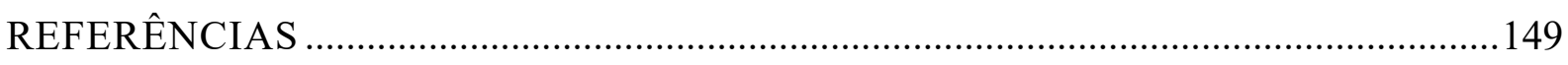

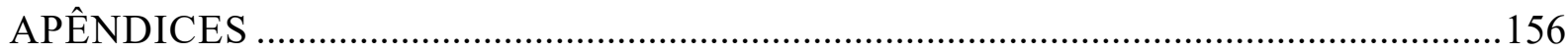




\section{INTRODUÇÃO}

Esta dissertação consiste em um estudo de caso acerca das ações do campus Diadema da Universidade Federal de São Paulo - Unifesp - que podem influenciar o desenvolvimento urbano e regional. Esse campus, cujas atividades iniciaram em 2007, é fruto de políticas de expansão universitária que vigoraram no Brasil a partir de 2003, sendo que um dos objetivos era induzir o desenvolvimento das diversas regiões do país.

Dentre estas políticas houve duas principais, conhecidas por "Expansão I" e "Reuni", que nortearam os investimentos públicos e garantiram um aumento significativo do número de universidades e de campi. A expansão teve como destaque a localização dos campi, sobretudo, no interior do país e nas bordas de metrópoles, áreas historicamente desassistidas por estas instituições.

A expansão em questão suscitou uma série de estudos tanto em relação às políticas públicas que lhe deram origem, principalmente no campo da educação e da sociologia, quanto em outras áreas do conhecimento, como a economia e a geografia, que abordaram a relação entre a expansão das universidades e o processo de desenvolvimento urbano e regional. Nesse caso, foram avaliados, sobretudo, os impactos que a instalação de novos campi produziu sobre cidades pequenas e médias, além de resgatarem este tema a partir de abordagens práticas.

A relação entre universidades e o desenvolvimento urbano e regional, no Brasil, data da década de 1960, entretanto, a primeira política pública que se tomou conhecimento e que versava objetivamente sobre as universidades como ferramenta para a promoção do desenvolvimento regional é o I Plano Nacional de Desenvolvimento, de 1971. Desde então, o Brasil tem acompanhado o discurso internacional de utilizar suas universidades, sobretudo as públicas, como ferramenta importante para o desenvolvimento regional.

De maneira geral, esse discurso se fundamenta na importância que as pesquisas produzidas pelas e com as universidades têm na chamada economia do conhecimento, aquela baseada na inovação, na transformação da produção e na criação de novos produtos e de novas demandas. Nesse sentido, a realização de pesquisas relacionadas às indústrias é condicionante para o desenvolvimento das atividades produtivas. 
Já o "desenvolvimento regional", para as economias capitalistas e os conceitos mais utilizados, é fruto da industrialização, ou seja, quanto mais as indústrias produzissem, melhores seriam os índices sociais e econômicos da população, uma vez que tais mudanças elevariam o PIB, os níveis de emprego, os salários dos empregados, o padrão de consumo e, consequentemente, haveria rebatimentos para o espaço urbano, portanto desenvolvimento urbano, uma vez que mais pessoas teriam mais acesso à moradia, ao comércio e ao serviço.

Todavia, sabe-se que os níveis de produção industrial não guardam relação direta e proporcional com a elevação dos níveis de vida da população, uma vez que os produtos da industrialização de uma região ou país são apropriados de formas desiguais. Isso pode ser explicado por uma noção de economia que compreende a sociedade como um todo e seu modo de produção, ao qual corresponde uma ordem social e uma organização do território.

Assim, definiu-se como principal questão de pesquisa compreender de que forma o campus Diadema é parte do processo de desenvolvimento urbano e regional. Interessa saber como pode incidir sobre a produção industrial, sobre as condições de vida da população e sobre o espaço urbano.

De forma ampla, o campus e suas atividades acadêmicas e administrativas podem provocar transformações do espaço urbano, assim como incidir sobre políticas públicas, e firmar parcerias com os setores privado e público. Em outras palavras, o campus e sua comunidade são agentes que atuam com outros agentes locais e regionais.

No entanto, ao longo da pesquisa, verificou-se que não houve transformações do espaço urbano em Diadema motivadas pela instalação do campus, como ocorreu em municípios menores, como apresentado no estudo de BRÜNE (2015a), por exemplo. Entretanto, o campus possui parcerias com órgãos públicos, empresas privadas e oportunidades de projetos de pesquisa em conjunto com a comunidade externa, além de participar da elaboração de políticas públicas setoriais. Essas ações incidem sobre o desenvolvimento urbano e regional. Isso não significa que o campus produziu alterações nos índices econômicos, sociais, urbanos e regionais, entre outros, uma vez que isto é produto de um complexo arranjo social.

A escolha do campus Diadema aconteceu por dois fatores. Em primeiro lugar porque é local de trabalho do pesquisador desde 2015, período posterior à primeira fase de implantação e consolidação do campus, que foi ênfase da avaliação. Em segundo lugar porque trata-se de um 
campus em situação diversa à maioria de outros estudos semelhantes, que se debruçaram sobre cidades pequenas e médias.

Além disso, o campus tem uma especificidade programática que o diferencia dos demais campi da própria Unifesp e estabelece um contraste com o contexto urbano e regional, como o fato de haver cursos de química, química industrial, engenharia química, farmácia, ciências ambientais, ciências biológicas e licenciatura em ciências. A partir disso é possível observar duas questões: a primeira é que os cursos guardam estreita relação com as maiores indústrias da região (metalurgia, química e farmácia); a segunda é que se tratam de áreas do conhecimento com intensa aplicação de tecnologia, o que implica a necessidade de laboratórios altamente equipados, relativos não apenas à disponibilidade de infraestrutura, mas também à sua qualidade.

Em contrapartida, o campus situa-se em um município cujo espaço urbano foi formado nos últimos 70 anos, marcado pela urbanização incompleta, irregular, partido entre grandes áreas industriais e de moradia, com predomínio de autoconstruções e socialmente frágil, principalmente por conta de baixos salários e baixos níveis históricos de escolaridade. Por outro lado, por ser local de trabalho do pesquisador, foi definida uma metodologia de pesquisa que pudesse reunir a vivência, o estudo in loco e entrevistas ${ }^{1}$, à luz da densa teoria existente, assim como o levantamento de dados primários e secundários.

Assim, parte importante das perguntas de pesquisa levantadas e das respostas encontradas, devem-se à presença do pesquisador, que permitiu o conhecimento de fatos e problemáticas que envolvem o campus, no tocante às questões sobre desenvolvimento urbano e regional, assim como o conhecimento de informações não registradas ${ }^{2}$. Essas informações permitiram o direcionamento das enquetes e entrevistas elaboradas, a fim de verificá-las ou de ampliar o conhecimento que se tinha.

Dessa forma, optou-se pela aplicação de enquetes, no modelo disponível anexo, que tinham por objetivo mapear o local de moradia, as relações e percepções do espaço urbano, assim como procurar por pistas que encaminhariam para entrevistas. Foram respondidas 42 enquetes entre os docentes, de um total aproximado de 250 que trabalham no campus (esse número é

1 As entrevistas foram realizadas de acordo com os protocolos de ética. Todos os entrevistados assinaram o "Termo de Consentimento Livre e Esclarecido".

2 Algumas informações tornaram-se de conhecimento do pesquisador através da vivência no dia a dia do campus, em conversas informais ou a partir das entrevistas, muito embora não estejam registradas nos documentos oficiais da universidade. 
flexível porque há docentes em trânsito), o que corresponde a 16,8\%. Entre os técnicos, que somam 110, foram respondidas 21 enquetes (19\%).

As perguntas foram abertas para permitir respostas amplas, de forma que se poderia encontrar indicações de aspectos que não haviam sido elaborados pelo pesquisador e, além disso, permitiram aos docentes e técnicos indicar trabalhos que realizavam com a comunidade externa. As respostas foram organizadas, agrupadas e cruzadas para fim de análise.

Procurou-se fazer um trabalho semelhante entre os estudantes, exceto pela visão de médio e longo prazo, já que eles permanecem por poucos anos na universidade (comparado aos técnicos e docentes). Entretanto, não se obteve uma participação significativa, sobretudo porque não há um canal de comunicação eficiente com eles ${ }^{3}$. Em substituição à enquete, procurou-se por estudos da própria universidade que permitissem, ao menos, mapear a origem dos estudantes.

Foram localizadas três publicações da universidade sobre o perfil dos ingressantes, de $2011^{4}, 2015^{5}$ e $2016^{6}$. Apenas o estudo de 2011 indica que 52\% dos estudantes residia em São Paulo no momento da matrícula, os demais municípios foram agrupados como "outros municípios da RMSP”. Nos estudos de 2015 e 2016 não há dados sobre município de origem, mas apontam que $67,8 \%$ e 70\%, respectivamente, dos ingressantes não pretendiam residir em Diadema.

Ademais, não há dados públicos que permitam definir a origem dos estudantes por município e onde eles residiram durante o curso. Há apenas um estudo realizado para o projeto de moradia estudantil, apresentado em congregação de 12 de maio de 2016, que contém as informações do local de moradia prévio e durante o curso por município, mas não foi concedida a

3 A comunicação com os estudantes é uma dificuldade que o próprio campus enfrenta. Não existe uma plataforma que facilite a comunicação; e-mail ou redes sociais são ineficazes. As representações estudantis são frágeis e não há um diretório acadêmico encorpado. Também não foi possível formalizar contatos com os estudantes das empresas juniores a tempo.

4 UNIVERSIDADE FEDERAL DE SÃO PAULO. O perfil socieconômico e cultural dos estudantes da Universidade Federal de São Paulo (sic). 2011. Disponível em: <http://www.unifesp.br/reitoria/prae/institucional/ prae/comissoes/cepeg/documentos/perfil-geral?download=78:estudo-do-perfil-socioeconomico-e-cultural-dos-estudantes-da-unifesp-ingressantes-2011>. Acesso em 22/01/2019.

5 UNIVERSIDADE FEDERAL DE SÃO PAULO. Análise do perfil de estudantes ingressantes da Universidade Federal de São Paulo. 2015. Disponível em: <http://www.unifesp.br/reitoria/prae/institucional/prae/comissoes/cepeg/documentos/perfil-geral?download=347:analise-perfil-ingressantes-2015> . Acesso em 22/01/2019.

6 UNIVERSIDADE FEDERAL DE SÃO PAULO. Análise do perfil de estudantes ingressantes da Universidade Federal de São Paulo - 2016. 2016. Disponível em: <http://www.unifesp.br/reitoria/prae/institucional/prae/ comissoes/cepeg/documentos/perfil-geral?download=460:relatorio-cepeg-2016>. Acesso em 22/01/2016 
permissão de uso. Portanto, não se realizou com os estudantes a mesma análise que se fez como com técnicos e docentes.

Também se cogitou a realização de enquetes com os funcionários das empresas terceirizadas que prestam serviços de limpeza, manutenção predial, vigilância, entre outros, afim de identificar se são empregados moradores das proximidades do campus. Todavia há uma grande rotatividade porque não há vínculos entre eles e a universidade, de forma que o panorama varia muito rapidamente. Eles podem ser substituídos a cada renovação contratual, por decisão das empresas ou por solicitações justificadas do campus.

As entrevistas, por sua vez, foram semiestruturadas e tinham como objetivo verificar informações, aprofundar questões, assim como levantar outras para serem avaliadas. Foram realizadas 8 entrevistas presenciais, sendo 5 com docentes e 3 externas ao campus, com gravação de áudio, e cujas transcrições integrais estão nos anexos. Na impossibilidade de se agendar entrevistas presenciais, também foram coletadas informações através de e-mails.

Foram enviados 32 e-mails diretamente aos docentes. A diretoria acadêmica auxiliou encaminhando-os a todos os demais, em duas oportunidades. O projeto de pesquisa também foi resumidamente apresentado em congregação do campus. Foram recebidas 21 respostas, sendo que 3 resultaram em entrevistas presenciais. Além disso, alguns docentes foram convidados presencialmente a realizar a entrevista. Todos foram abordados com quatro perguntas principais, a saber:

1. Qual o foco da sua pesquisa na universidade?

2. Há empresas ou indústrias que já manifestaram interesse nas pesquisas do seu laboratório? Alguma parceria chegou a ser firmada?

3. Caso haja ou tenha havido parceria com empresas ou indústrias, você pode detalhar quais os objetivos da parceria? Qual a responsabilidade da empresa? E da universidade?

4. Houve interesse ou envolvimento com algum órgão ou repartição pública? Em que sentido?

Além dessas, foi acrescentada uma quinta, que solicitava ao docente indicar um colega que tivesse parcerias com empresas ou órgãos públicos, uma vez que foram recebidas apenas 21 respostas e 8 delas eram negativas para a existência presente ou passada de parcerias. As res- 
postas positivas foram filtradas de acordo com o recorte da pesquisa, apresentadas e analisadas no capítulo 3.

As entrevistas realizadas presencialmente eram iniciadas com um espaço para o docente contextualizar sua presença no campus e contar um pouco da sua história, quando emergiam opiniões pessoais sobre a consolidação do campus, ou sobre Diadema. Em seguida, foram indagados sobre seus projetos de pesquisa e extensão, que já se sabia anteriormente que guardavam relações com empresas ou com a prefeitura. No fim, foram feitas questões elaboradas no momento, de acordo com o que era levantado durante a entrevista, para detalhar pontos específicos.

Entre os docentes, uma entrevista em especial foi realizada com o então diretor acadêmico do campus, João Alexandrino, que detinha uma posição de pivô, capaz de indicar diversos trabalhos e posturas que o campus tinha sobre o seu entorno, físico e social, além de parcerias realizadas e em andamento.

Já entre os membros externos à comunidade foram feitas entrevistas com membros ligados ao Centro das Indústrias de São Paulo - Ciesp Diadema - e um industrial da área de mecânica e eletrônica ${ }^{7}$, que também já foi ligado ao Ciesp. Nestas entrevistas procurou-se levantar questões relativas à condição da indústria de Diadema e região do $\mathrm{ABC}$, assim como as perspectivas em relação ao trabalho em parceria com as universidades e, em especial, com o campus Diadema.

Uma última entrevista realizada foi com o ex-prefeito de Diadema, José de Filippi Junior, que atuou diretamente na implementação do campus no município. Esta teve como objetivo levantar dados históricos externos ao campus e, também, os atores e arranjos políticos que permitiram a instalação do campus. Além disso, procurou-se saber algumas expectativas que se tinha quando a prefeitura decidiu trabalhar para viabilizar o campus em seu município.

Com relação à estrutura da dissertação, optou-se por uma divisão em 3 capítulos, além da introdução e das considerações finais., conforme segue. O capítulo 1 aborda as políticas de expansão do ensino superior entre 2001 e 2010, bem como a relação que tinham com o desenvolvimento urbano e regional. Em seguida, há uma apresentação e discussão sobre os conceitos de "desenvolvimento urbano e regional", de forma que se pudesse fundamentar as escolhas e perguntas que foram formuladas para a realização da pesquisa.

7 O contato prévio com esses três entrevistados se fez através da participação do autor deste estudo na revisão do Plano Diretor de Diadema, como membro da sociedade civil. 
De forma geral se apontou que há conceitos muito variados e que o apresentado por FURTADO (1980) somado a outros de VILLAÇA (1998) seriam mais adequados à perspectiva do autor. Sumariamente, FURTADO (1980) define o "desenvolvimento" como as transformações que passa uma sociedade, sendo que "economia" é o seu modo de produção, relativo a uma estrutura social. Já para VILLAÇA, a uma estrutura social corresponde uma estrutura espacial. Logo, passou-se a compreender o desenvolvimento urbano e regional como as transformações da estrutura produtiva, social e espacial, de uma região e da cidade.

Por fim, conclui-se o capítulo 1 com uma apresentação sobre outras pesquisas semelhantes que realizaram estudos de caso em outras cidades. São apresentadas as formas de abordagem de cada uma delas ao tema, assim como destacados elementos importantes para a análise da relação das universidades com o desenvolvimento urbano e regional. Foi a partir desse conjunto de elementos, somados às questões apresentadas na sessão 1.1 e dos conceitos da 1.2, que se estruturou a pesquisa.

O capítulo 2 trata especificamente sobre o município de Diadema. Embora a pesquisa considere desenvolvimento regional, as respostas encontradas apontam para relações limitadas pela divisão municipal. Ainda assim, o item 2.1, que trata sobre a formação do espaço urbano em Diadema, procurou proceder a uma análise do espaço, considerando o contexto em que aconteceu, sobretudo com São Paulo, Santo André e São Bernardo. Esse item procura levantar da história as qualidades do espaço e as razões que possam explicar a relação do campus com a cidade, assim como de quais formas seria possível o campus incidir sobre ela.

Já o item 2.2 procura trazer aspectos mais atuais sobre a condição de Diadema, com foco sobre a questão das indústrias e a importância da instalação do campus para potencializar ou modificar o cenário. Neste ponto se destaca a discussão que entrelaça a condição da indústria de Diadema, o processo de desindustrialização (se vigente ou não) e as relações entre as indústrias e a pesquisa. Para isso, foram levantados dados bibliográficos e, principalmente, parte das entrevistas realizadas para esta pesquisa.

Por fim, o item 2.3 desenvolve a noção de que há um déficit educacional em Diadema, que é histórico e está presente, em partes, na formação do espaço urbano. Faz-se uma análise qualitativa que tem por objetivo dar um panorama geral do estado da formação escolar dos cidadãos de Diadema, para indicar de quais maneiras isso impacta no acesso à universidade pública e, no sentido contrário, como a universidade pode transformar esse panorama. 
Por sua vez, no capítulo 3 apresentam-se as ações do campus que se relacionam com o processo de desenvolvimento urbano e regional. No item 3.1 isto é mostrado a partir do ponto de vista histórico, com os fatos mais relevantes que demonstram o arranjo político e alguns atores que participaram da implementação do campus. Além disso, são expostas as dificuldades que foram atravessadas ao longo dos anos e, sobretudo, a relação estabelecida com a cidade, tanto em relação ao espaço urbano quanto em relação aos âmbitos social e político. Ademais, compõe esse item as informações levantadas nas entrevistas, as conversas informais e a pesquisa documental que se procedeu sobre as atas de congregações de campus, conselho universitário - CONSU - e legislações diversas.

Já nos itens 3.2 a 3.4 estão relatados os trabalhos que o campus realizou ou realiza que possam ser importantes para o desenvolvimento urbano e regional, separados de acordo com o tripé universitário: ensino, pesquisa e extensão. Desta forma, procurou-se destacar não apenas o que o campus realiza, mas também como suas ações e posturas estão intimamente ligadas ao contexto urbano e regional, o que se relaciona com o que foi apresentado nos capítulos anterio-

res. É, inclusive, nesta parte do trabalho que se apresentam os resultados levantados a partir das entrevistas com os docentes.

O item 3.5 tem duas partes principais. A primeira é uma relação direta com a bibliografia consultada, que concentrou grande parte da sua atenção para os impactos urbanos que a instalação de uma universidade ou campus pode produzir sobre o espaço urbano. Imaginava-se, a priori, que haveria poucos impactos produzidos pelo campus Diadema, mas, ainda assim, acreditava-se que era importante confirmar isso e explicar por que difere dos outros estudos. Para isso, foram apresentadas e discutidas as informações e dados obtidos através das enquetes com docentes e técnicos, além da própria observação do entorno das unidades do campus.

A segunda parte desse item é uma análise de outros aspectos da relação do campus com o espaço urbano, sobretudo de que forma a urbanização afetou a instalação e consolidação do campus, assim como de quais formas o campus interfere sobre o espaço construído.

Já nas considerações finais procurou-se fazer a análise das informações levantadas no decorrer do capítulo 3 , à luz da bibliografia consultada assim como do cruzamento de informações separadas ao longo dos capítulos. A análise foi feita, também, com informações e dados abordados durante as entrevistas, que não abordam posturas e trabalhos do campus Diadema, propriamente ditos, mas questões mais gerais que importam na interpretação dos resultados obtidos. 


\section{POLÍTICAS DE EXPANSÃO DO ENSINO SUPERIOR E O DESEN- VOLVIMENTO URBANO E REGIONAL.}

As políticas de expansão das universidades federais da primeira década dos anos 2000 tiveram como importante elemento a intenção de promover o desenvolvimento regional a partir da instalação de novos campi universitários espalhados pelo país. A relação entre desenvolvimento regional e universidades está longe de ser uma novidade trazida por essas políticas, afinal, isso se preconiza no Brasil desde a década de 1950 e, ainda antes, na Europa e nos Estados Unidos.

Dentre outros aspectos das políticas de expansão do ensino superior, o que as diferencia das anteriores é que elas não fizeram apenas crescer o número de universidades, campi e vagas no ensino superior, mas também conduziram a criação de universidades públicas em áreas interioranas do país e periferias de metrópoles, que não eram dotadas deste equipamento.

Sendo assim, a seguir, serão apresentadas as políticas de expansão do ensino superior entre os anos 2001 e 2010, bem como a relação dessas políticas com o processo de desenvolvimento urbano e regional para destacar de que formas as universidades podem colaborar com esta questão.

\subsection{As políticas de expansão do ensino superior no Brasil entre 2001 e 2010}

A expansão das universidades federais é uma das marcas mais expressivas do governo de Luís Inácio Lula da Silva. Entre 2003 e 2010 foram criadas 14 novas universidades, que foram somadas às 45 existentes em 2002, totalizando, assim, 59. O número de municípios atendidos pela rede federal passou de 114, em 2003, para 237 em 2011 (MEC, 2012), fruto não só da criação de novas universidades, mas também da expansão das existentes.

Essa expansão pode ser verificada através da figura 1, que demonstra a evolução nas vagas de graduação presencial entre 2003 e 2011, assim como na figura 2, que aponta a quantidade de universidades federais criadas por períodos, e também na figura 3, que contém as quantidades totais de universidades federais ao longo do tempo. 
Figura 1 - Vagas na graduação presencial em universidades federais (2003 a 2012).

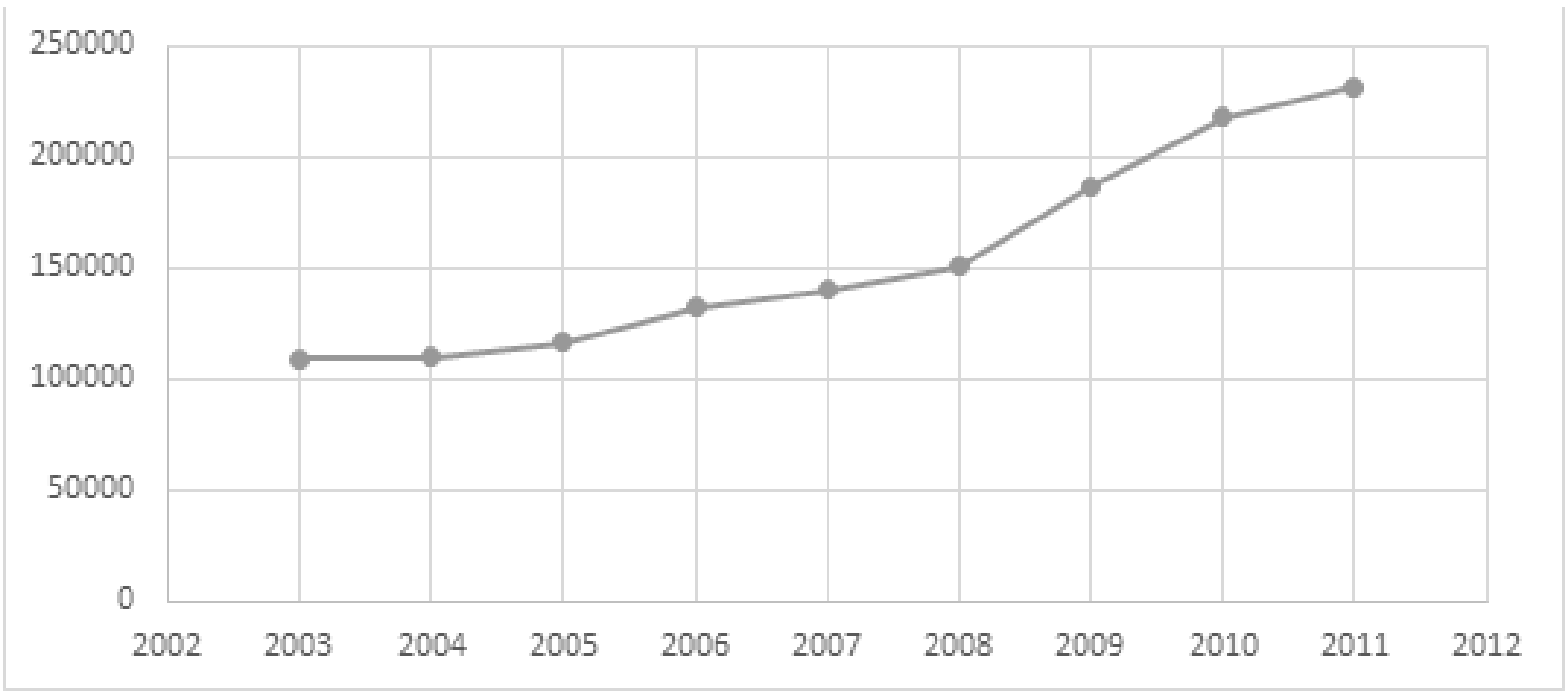

Fonte: Censo/INEP - Elaboração própria.

Figura 2 - Universidades federais criadas por período.

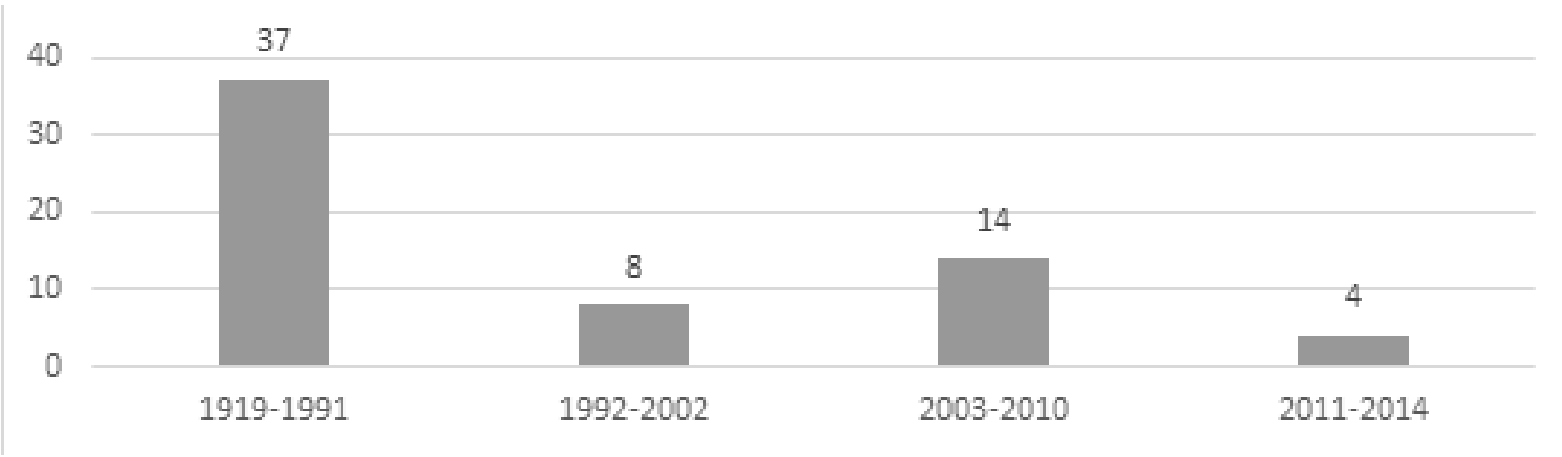

Fonte: Capes/MEC - Elaboração própria.

Figura 3 - Total de universidades federais por ano (2003 a 2010).

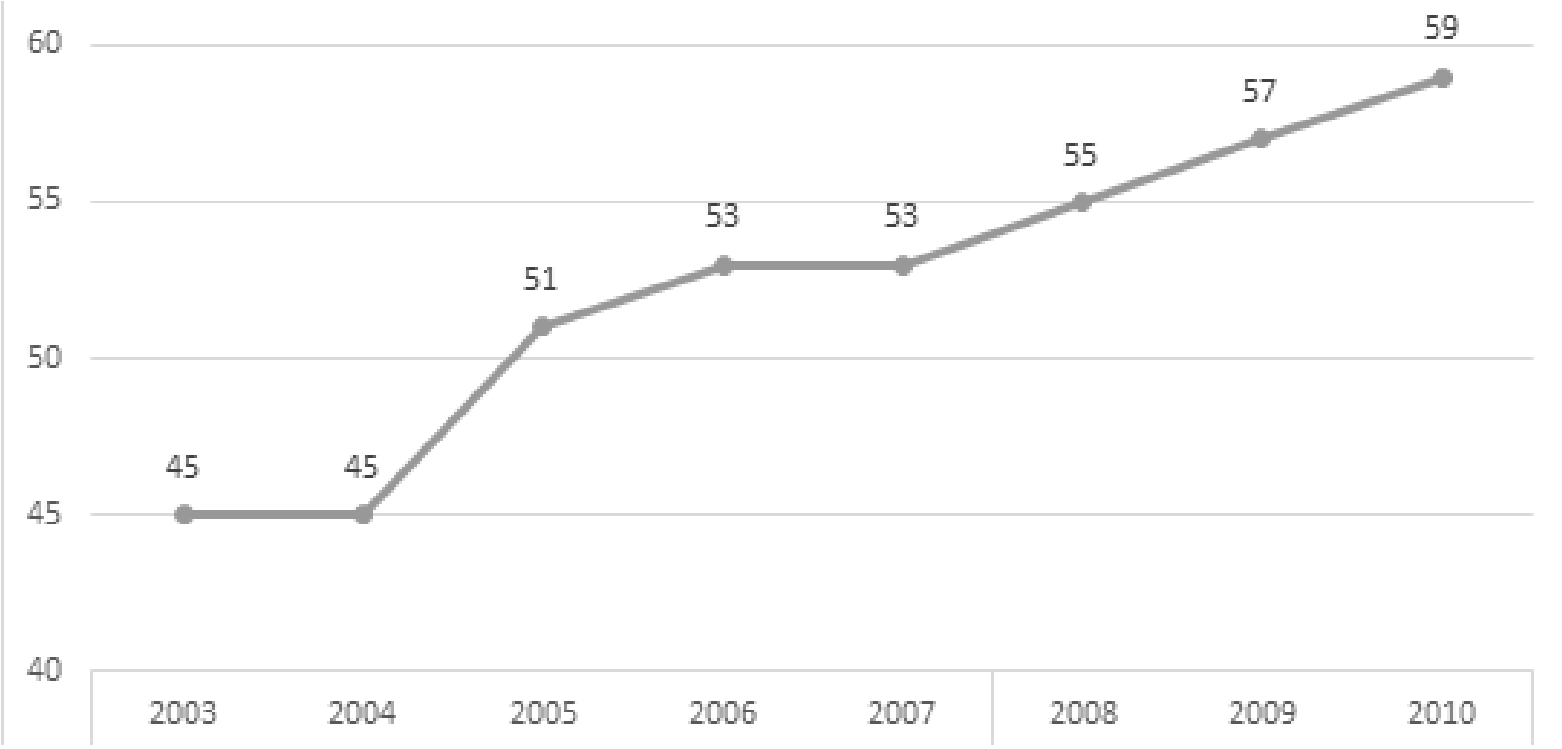

Fonte: Capes/MEC - Elaboração própria. 
Esse crescimento, somado a uma alteração no padrão de acesso à universidade, motivou Gentili e Oliveira (2013) a defenderem que as políticas de expansão do governo Lula democratizaram as universidades federais, diferentemente do período de seu antecessor, Fernando Henrique Cardoso, quando houve um baixo crescimento dessas universidades:

\footnotetext{
[Lula e Haddad optaram por] fazer uso de todos os meios ao seu alcance para promover a democratização da educação como instância iniludível no processo de democratização da sociedade brasileira. Com essa ação, o governo Lula optou por disciplinar e regular a educação superior privada no país ao mesmo tempo que possibilitou que mais de 1 milhão de jovens pobres se tornassem a primeira geração de estudantes nas suas respectivas biografias familiares. O que o governo Fernando Henrique privatizou no campo universitário o governo Lula tentou dotar de conteúdo social e potencial democratizador (GENTILI e OLIVEIRA, 2013, p. 257).
}

Uma opinião diferente desta pode ser encontrada no trabalho de Barros (2015), que avalia que o governo Lula foi, em amplo sentido, uma continuação do governo antecessor:

[o PROUNI representa] "a adesão do governo Lula às concepções neoliberais e às orientações do Banco Mundial9 à medida que intensifica o processo de estati zação das vagas nas instituições privadas por meio da transferência de recursos públicos. Nesse sentido, tal medida foi bastante criticada por promover uma democratização 'às avessas"” (BARROS, 2015, p. 371).

Todavia, a revisão dos planos que fundamentaram a expansão das universidades demonstra que, em alguns aspectos, houve continuidade das políticas de FHC e em outros uma ruptura. Por isso, se analisou desde o Plano Nacional de Educação, de 2001 (PNE-2001) até sua revisão em 2010 (PDE-2010), passando pelo Plano de Desenvolvimento da Educação e o Reuni (2007), além do Plano de Ação em Ciência, Tecnologia e Inovação para o Desenvolvimento Nacional (PACTI - 2007). Essa revisão é importante porque através dela se buscará compreender a questão da territorialização destas políticas para, posteriormente, compreender qual conceito continham sobre o desenvolvimento regional, e quais aspectos da relação universidade-desenvolvimento regional devem ser observados.

O ponto de partida para a expansão das universidades públicas federais foi dado ainda em 2001, quando Fernando Henrique Cardoso sancionou o Plano Nacional de Educação (PNE 2001) que tinha como objetivo garantir a matrícula, no ensino superior, de $30 \%$ dos jovens entre 18 e 24 anos. Apesar disso, este plano não contém diretrizes e não aponta quais seriam as estratégias e as ferramentas necessárias para atingir a meta.

Outra questão importante do PNE 2001 é a previsão de cenários futuros, dentre os quais está o aumento do ingresso das classes mais baixas no ensino superior como tendência para a 
década que se iniciava. Segundo o documento anexo à lei 10.172/2001, “A matrícula no ensino médio deverá crescer nas redes estaduais, sendo provável que o crescimento seja oriundo de alunos das camadas mais pobres da população. Isto é, haverá uma demanda crescente de alunos carentes por educação superior.” (BRASIL, 2001). E, por isso, prevê no objetivo 19 do item 4.3 - Metas e objetivos:

Criar políticas que facilitem às minorias, vítimas de discriminação, o acesso à educação superior, através de programas de compensação de deficiências de sua formação escolar anterior, permitindo-lhes, desta forma, competir em igualdade de condições nos processos de seleção e admissão a esse nível de ensino. (BRASIL, 2001)

Destaca-se, também que, quanto à desigualdade regional, o PNE 2001 considerava que havia "uma distribuição de vagas muito desigual" (BRASIL, 2001) no ensino superior, que deveria ser corrigida e que "esta desigualdade resulta da concentração das matrículas em instituições particulares das regiões mais desenvolvidas. O setor público, por outro lado, está mais bem distribuído e cumpre assim uma função importante de diminuição das desigualdades regionais" (BRASIL, 2001 ), função esta que deveria ser preservada. Neste ponto temos a primeira menção à universidade pública federal como uma importante ferramenta para o desenvolvimento regional.

Logo no início do governo Lula, em 2003, foi lançado o programa "Expansão” que, apesar de comentado em diversos trabalhos não contém documento público nem foi possível obter informações mais detalhadas. Segundo Nascimento e Helal (2015), diferentemente dos demais programas lançados na sequência, não houve uma legislação específica que implementasse o programa "Expansão". Este programa também é encontrado com os nomes de "Expansão I", em Barros (2015), Padim (2014), e (PADIM, 2014), “Expandir” ou “Expansão para o interior” em Nascimento e Helal (2015) e Jesus (2016).

Entretanto, é possível observar que esta foi uma política que resultou em uma forte expansão da rede federal, como posto nas figuras 1, 2 e 3, acima. De acordo com Nascimento e Helal (2015), foram criadas quatro novas universidades, 50 novos campi e atendidos 68 novos municípios, com o uso de aproximadamente R\$ 592 milhões.

Quatro anos mais tarde, já em 2007, o ex-presidente Lula lançou uma nova política para o ensino em substituição ao PNE de 2001, o Plano de Desenvolvimento da Educação - PDE - que, segundo a sua apresentação na cartilha "O Plano de Desenvolvimento da Educação: 
princípios, razões e programas" ${ }^{\prime}$, considerava inaceitável que, naquela época, apenas $11 \%$ dos jovens entre 18 e 24 anos estivessem matriculados no ensino superior, ainda mais levando em consideração que a meta do PNE de 2001 era chegar ao fim da década com 30\% desses jovens matriculados.

O PDE sustenta-se em seis pilares: “i) visão sistêmica da educação, ii) territorialidade, iii) desenvolvimento, iv) regime de colaboração, v) responsabilização e vi) mobilização social" (BRASIL, 2007, p. 11), e funciona como articulador entre diversas políticas públicas não apenas para expandir o ensino superior, mas, principalmente, para dotá-lo de sentido.

É o PDE que faz a articulação entre a expansão das universidades e o incremento das pesquisas, junto ao Plano de Ação em Ciência, Tecnologia e Inovação para o Desenvolvimento Nacional - PACTI. Neste caso, apesar de terem sido elaborados em ministérios distintos, da Educação e Cultura (MEC) e da Ciência, Tecnologia e Inovação (MCTI), respectivamente, houve diálogo entre as políticas e os planos, de tal forma que o PDE menciona o PACTI e viceversa.

O PACTI parte de três premissas:

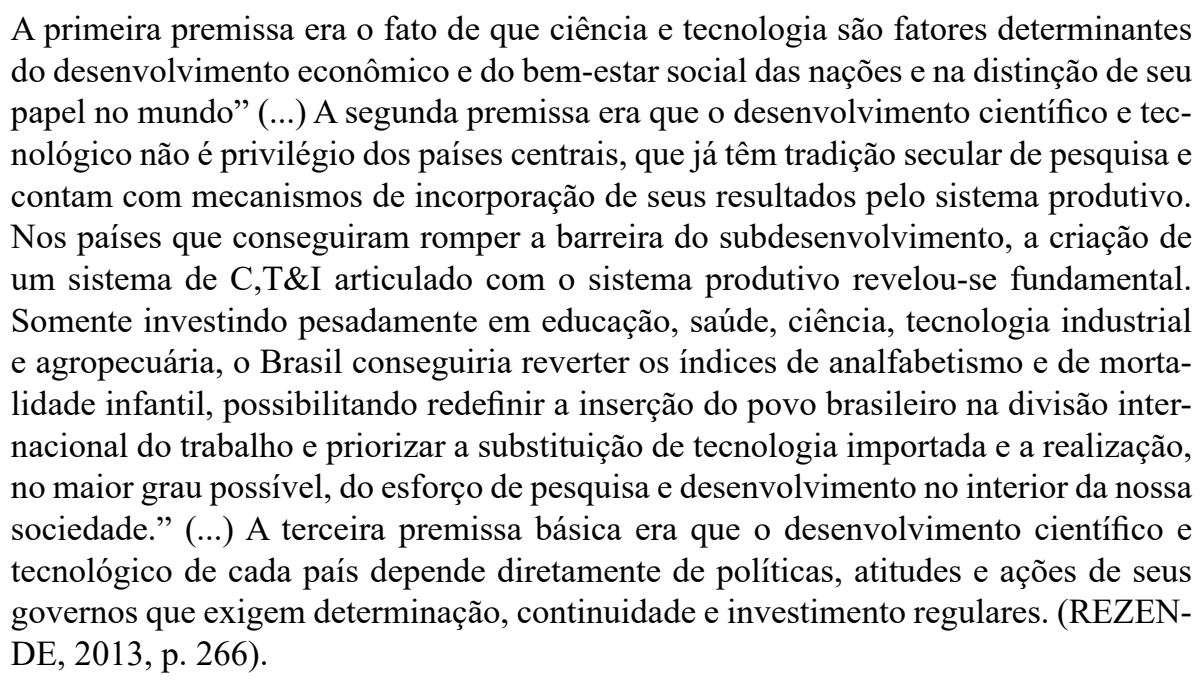

Foi a partir deste plano que se obteve uma expressiva expansão de ciência, tecnologia e inovação - CT\&I - a partir de 2007, tanto por um incremento importante de universidades públicas quanto pelo aumento da disponibilidade de financiamentos à pesquisa. O gráfico a seguir (figura 4) demonstra a evolução dos recursos disponíveis via Empresa Federal Financiadora de Estudos e Projetos - Finep - e, em seguida, a figura 5 ilustra o número de bolsas CNPq e Capes. 
Figura 4 - Recursos Finep entre 2000 e 2010.

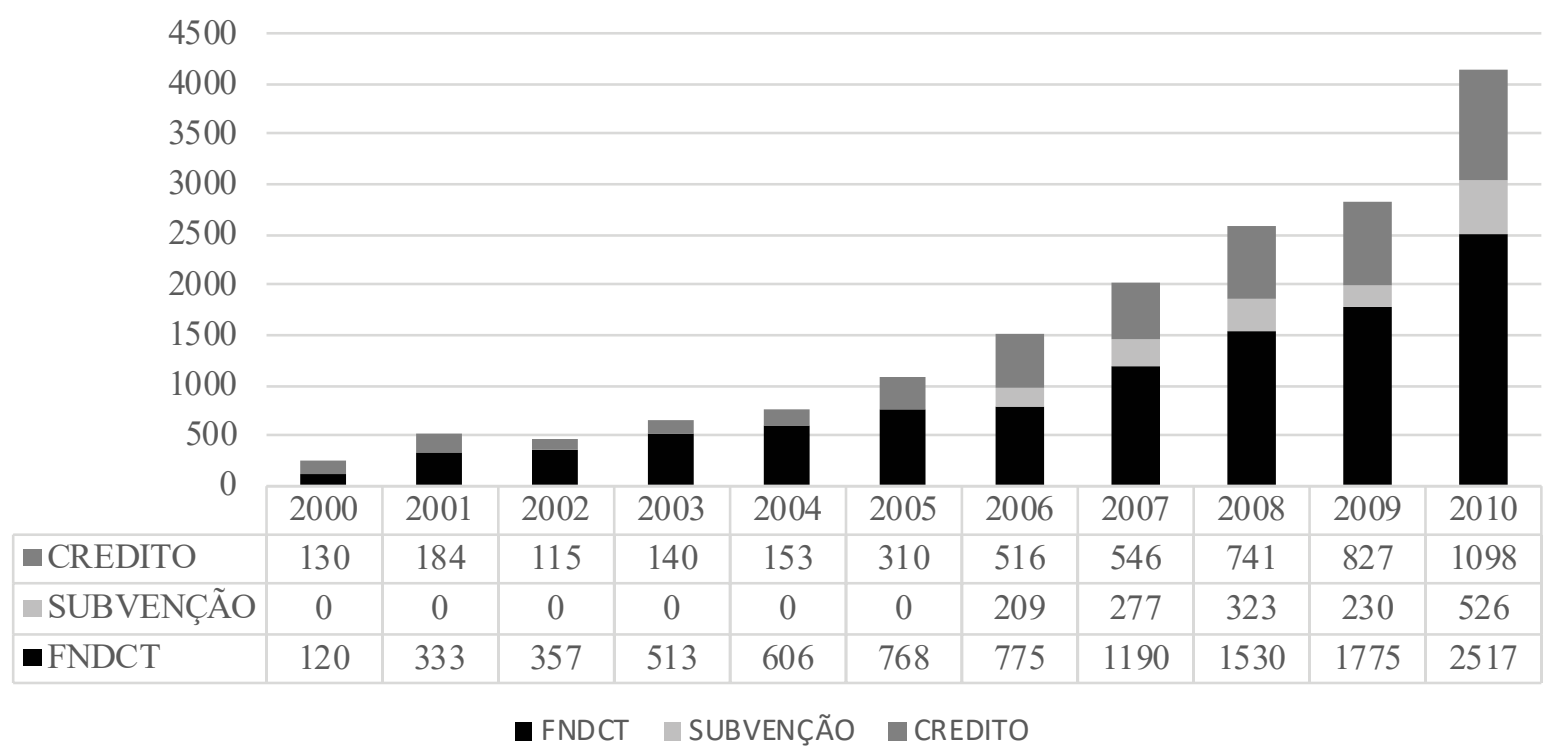

Fonte: Finep. Elaboração própria.

Figura 5 - Número de bolsas por ano do CNPq, Capes e total.

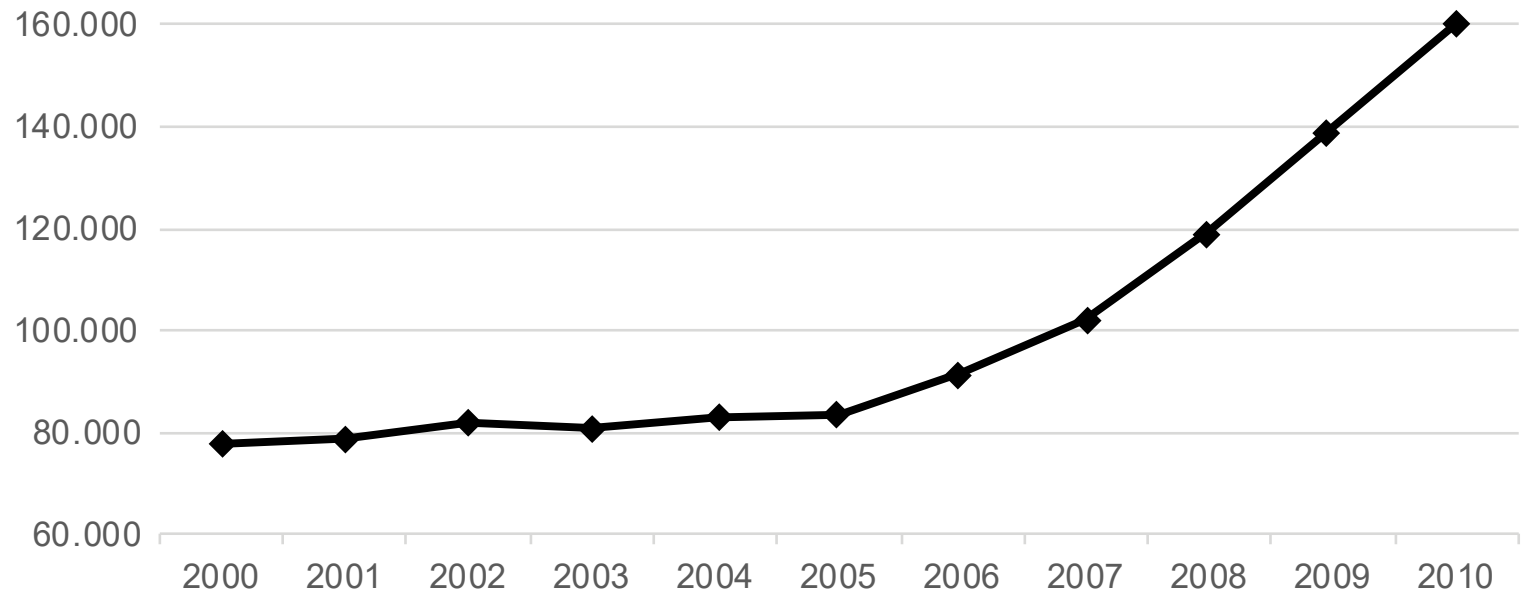

Fonte: MCTI. Elaboração própria.

De acordo com Rezende (2013), foi em grande parte devido ao PACTI que o Brasil aumentou sua produção científica a ponto de, em 2010, ter atingido a marca de 2,7\% da produção mundial, sendo que sua participação dobrou em relação ao ano 2000. Neste período, as publicações sofreram aumento de $205 \%$ e em 2008 o país já ocupava a $13^{\mathrm{a}}$ posição no ranking mundial, à frente de países como a Holanda e a Rússia. A expansão da pesquisa no Brasil só foi possível graças a um alinhamento entre os Ministérios da Educação e da Ciência e Tecnologia, sobretudo nos volumes de recursos aportados para a expansão das universidades e das pesquisas.

Ainda de acordo com Rezende, estes dados somados

ao nosso desenvolvimento econômico acelerado, tem contribuído para atrair a instalação de centros de pesquisa e desenvolvimento de empresas multinacionais no país. 
Somente em 2010 anunciaram suas decisões de instalar centros mundiais de pesquisa as americanas General Electric e IBM e a sueca SAAB. (2013, p. 277)

Nesse contexto, cabe ressaltar que, segundo o relatório "Reserach in Brazil" (Pesquisa no Brasil, em tradução livre), elaborado pelo Clarivate Analytics para a Capes entre 2011 e 2016, a produção científica brasileira está concentrada nas universidades públicas. Indústrias e empresas privadas colaboraram com menos de $1 \%$ de toda a publicação científica do período. Em consonância com a ponderação de Rezende (2013), as empresas privadas que mais contribuíram com publicações de pesquisas no Brasil são estrangeiras, do ramo farmacêutico, ultrapassadas apenas pela Petrobras.

Dentro do PDE encontra-se o Reuni - Programa de Apoio a Planos de Reestruturação e Expansão das Universidades Federais - que foi a política responsável pela expansão das universidades federais a partir de 2007. É nesse programa que se definem as estratégias e ferramentas para tal. Seus objetivos foram tratar da reorganização e da reestruturação das universidades federais para melhor aproveitarem o seus recursos humanos e infraestrutura, a fim de reduzir os custos relativos de operação e aumentar o ingresso de estudantes, assim como manter o projeto expansionista com criação de diversos novos campi nas universidades existentes.

De acordo com a cartilha de apresentação do PDE, o Reuni

é o instrumento que permite expandir e defender a universidade pública" [e tem]
"como fim imediato o aumento das vagas de ingresso e a redução das taxas de evasão
nos cursos presenciais de graduação. (...) O Reuni permite uma expansão democráti-
ca do acesso ao ensino superior, o que aumentará expressivamente o contingente de
estudantes de camadas sociais de menor renda na universidade pública. (BRASIL,
2007, p. 27).

A adesão das universidades ao Reuni se deu de forma voluntária, e a participação estava combinada com a obrigação da elaboração de planos tanto da expansão quanto da reorganização e da reestruturação física e educacional que permitissem o melhor aproveitamento das estruturas existentes. As universidades federais que aderiram ao programa receberam um aporte de recursos que permitiu uma segunda leva de crescimento, agora já não mais focado na expansão do número de universidades, mas sim no número de campi, o que fez com que muitas universidades aumentassem significativamente o seu raio de abrangência, passando a regionalizar-se.

A Unifesp - Universidade Federal de São Paulo - caso específico que interessa a este trabalho - aderiu ao programa e viu crescer seu número de campi de 2 (São Paulo e Baixada 
Santista), em 2006, para 6 em 2007, com a criação dos campi Osasco, Guarulhos, Diadema e São José dos Campos.

O resultado prático destas políticas para as universidades federais e o entendimento de que houve uma regulação do setor privado bastam para Gentili e Oliveira (2013) considerarem Lula em oposição a FHC. Todavia, Mancebo et al (2015) e Barros (2015) concordam que o governo Lula manteve a privatização do ensino superior, não através da retração da universidade pública, mas de um crescimento muito superior do privado e, principalmente, porque a regulação do ensino particular é contestável, para as autoras. Para elas, isso fica evidente pelo número crescente de vagas não preenchidas no ensino superior privado, conforme tabela 1 abaixo:

Tabela 1 - Vagas no ensino superior público e privado entre 2001 e 2010 e vacância de vagas. Elaboração própria a partir de dados do Censos da Educação Superior (INEP, 2001-2010).

\begin{tabular}{|c|c|c|c|c|}
\hline \multirow{2}{*}{ ano } & \multirow{2}{*}{ total de vagas } & \multicolumn{3}{|c|}{ vagas ociosas } \\
\cline { 3 - 5 } & 1.408 .492 & pública & privada & total \\
\hline 2001 & 11.877 & 359.925 & 371.802 \\
\hline 2002 & 1.773 .087 & 14.863 & 553.084 & 567.947 \\
\hline 2003 & 2.002 .733 & 14.132 & 725.647 & 739.779 \\
\hline 2004 & 2.320 .421 & 21.250 & 996.061 & 1.017 .311 \\
\hline 2005 & 2.435 .987 & 24.687 & 1.014 .019 & 1.038 .706 \\
\hline 2006 & 2.629 .598 & 33.698 & 1.147 .391 & 1.181 .089 \\
\hline 2007 & 2.832 .942 & 30.769 & 1.311 .218 & 1.341 .987 \\
\hline 2008 & 2.985 .137 & 36.725 & 1.442 .593 & 1.479 .318 \\
\hline 2009 & 3.164 .679 & 39.551 & 1.613 .740 & 1.653 .291 \\
\hline 2010 & 3.120 .192 & 36.775 & 1.493 .205 & 1.529 .980 \\
\hline
\end{tabular}

Fonte: INEP, 2001-2010

Entretanto, é preciso considerar que a formulação da política definia como um dos critérios para destinação de recursos para as universidades privadas o número absoluto de vagas sem, necessariamente, as ter preenchido. Portanto, não se trata de uma falha de regulação, mas sim da própria estrutura da política.

Tanto Mancebo et al (2015) quanto Barros (2015) enfatizam que o crescimento do ensino superior privado é um movimento a nível internacional que se relaciona diretamente com o processo de financeirização das economias nacional e global, que fomenta o lobby privatista que, de acordo com Mancebo, 
é poderoso e organizado. Faz-se representar no Conselho Nacional de Educação (CNE), e, graças a um sistema político dominado pelos interesses do capital, inclusive por meio do controle do financiamento eleitoral, o setor privatista é majoritário no Congresso Nacional, onde não se envergonha de apresentar propostas que respondem apenas aos interesses mercantis das instituições que representam. (MANCEBO et al, 2015, p. 37)

Este sentido privatizante pode ser observado na figura 6, que demonstra que a expansão das matrículas no ensino público foi muito inferior ao particular, chegando a 2010 com uma distribuição da ordem de $75 \%$ privado para $25 \%$ público. Também é possível perceber que o crescimento foi linear para as duas categorias, com uma variação entre 2007 e 2008 para o ensino público, fruto do PDE.

Figura 6 - Evolução das matrículas dos cursos de graduação presenciais e a distância no Brasil, por organização acadêmica (1995-2010).

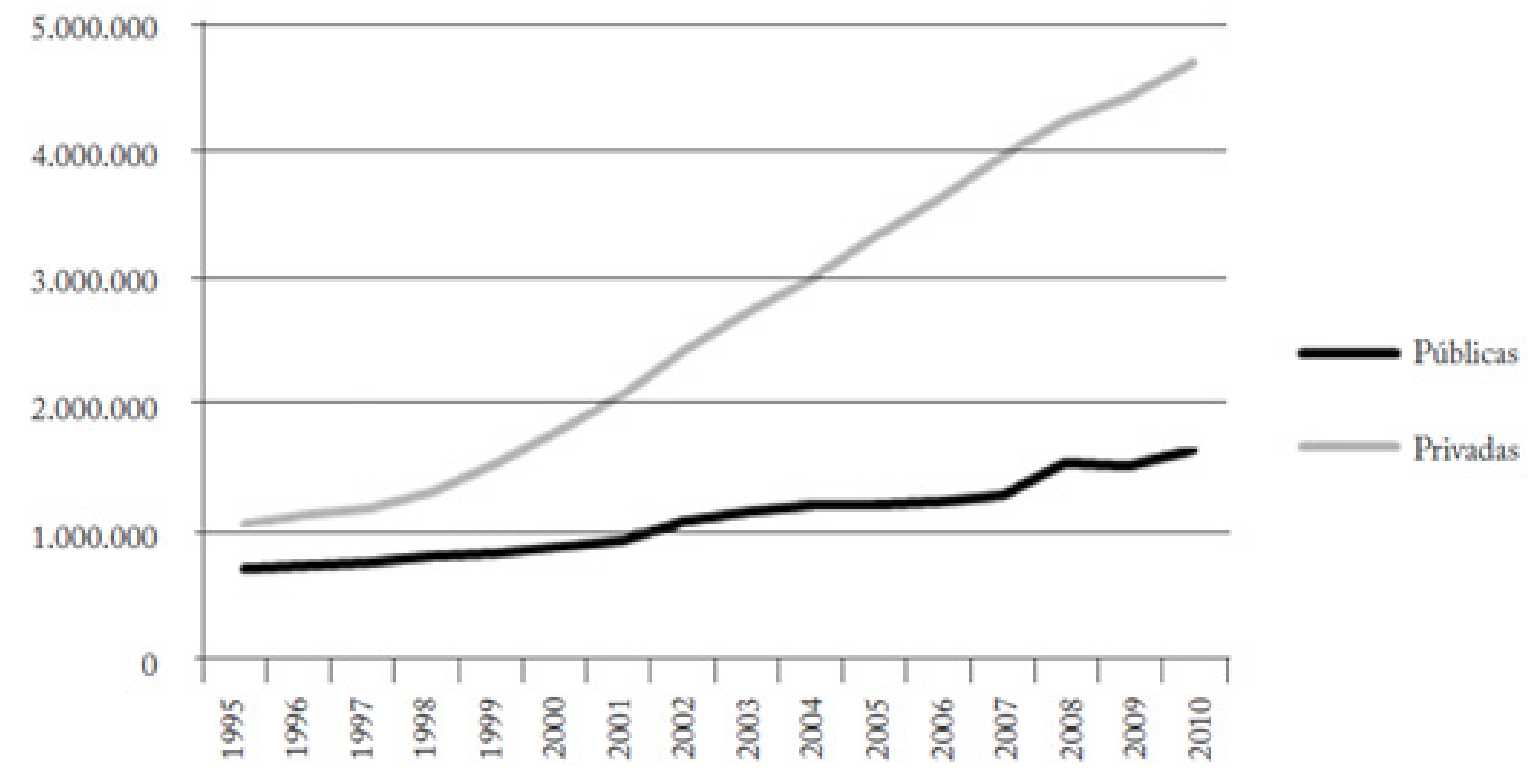

Fonte: MEC; INEP

Além disso, ao observarem-se as ações concretas do governo Lula, é possível inferir que parte delas estava prevista na PNE 2001, como o incremento do ensino à distância, redução das desigualdades regionais (em termos de oferta de vagas em universidades públicas) e a adoção de políticas de inclusão e permanência 9 .

Essas políticas são formas de garantir o acesso dos mais pobres à universidade, (seja por cotas ou por financiamento), e também meios para que estes estudantes tenham condições mínimas de seguir os estudos até o fim. Entre essas políticas estão o auxílio à moradia, subsídios

9 A PNE 2001 previu que haveria aumento do acesso de estudantes de baixa renda ao ensino superior público e que isso demandaria políticas que garantissem a conclusão dos seus estudos. 
para o funcionamento de restaurantes universitários, e bolsas de auxílio. O conjunto de políticas de expansão, de inclusão e de permanência possibilitou a alteração do perfil do estudante do ensino superior no país, que viu crescer o número de matriculados provenientes das classes $\mathrm{C}$ e D.

Apesar disso, e de não ter atingido a meta prevista pelo PNE 2001, as universidades públicas federais expandiram-se e tomaram o rumo de interiorização que se previa para elas. Os mapas das figuras 7 e 8, a seguir, demonstram que o processo fez com que muitas regiões desassistidas ou que participavam de forma desigual da totalidade das universidades federais passassem a ver reduzido o fosso que as separava das regiões mais privilegiadas.

Passando da escala nacional para a estadual, pode-se ver que também houve um espraiamento das universidades no território, sobretudo no sul do país. No caso específico aqui estudado, houve expansão na RMSP: a criação da UFABC e os novos campi da Unifesp (Diadema, Osasco, Guarulhos e, posteriormente, Zona Leste), que foram chamados por Fernando Haddad, então ministro da educação, de “Anel Universitário” (HADDAD, 2018).

Portanto, pode-se inferir que a expansão das universidades federais é resultado de uma série de políticas públicas que vinham sendo criadas e aplicadas desde 2001, que se tornou consubstancial porque foi acompanhada pelo aumento de verbas para inovação e pesquisa, além da definição de diretrizes e de ferramentais claros e objetivos. Em outras palavras: a política para inovação e pesquisa, bem como a sua disponibilidade orçamentária, deu sentido à expansão universitária. 
Figura 7 - Localização dos campi das universidades federais em 2002.

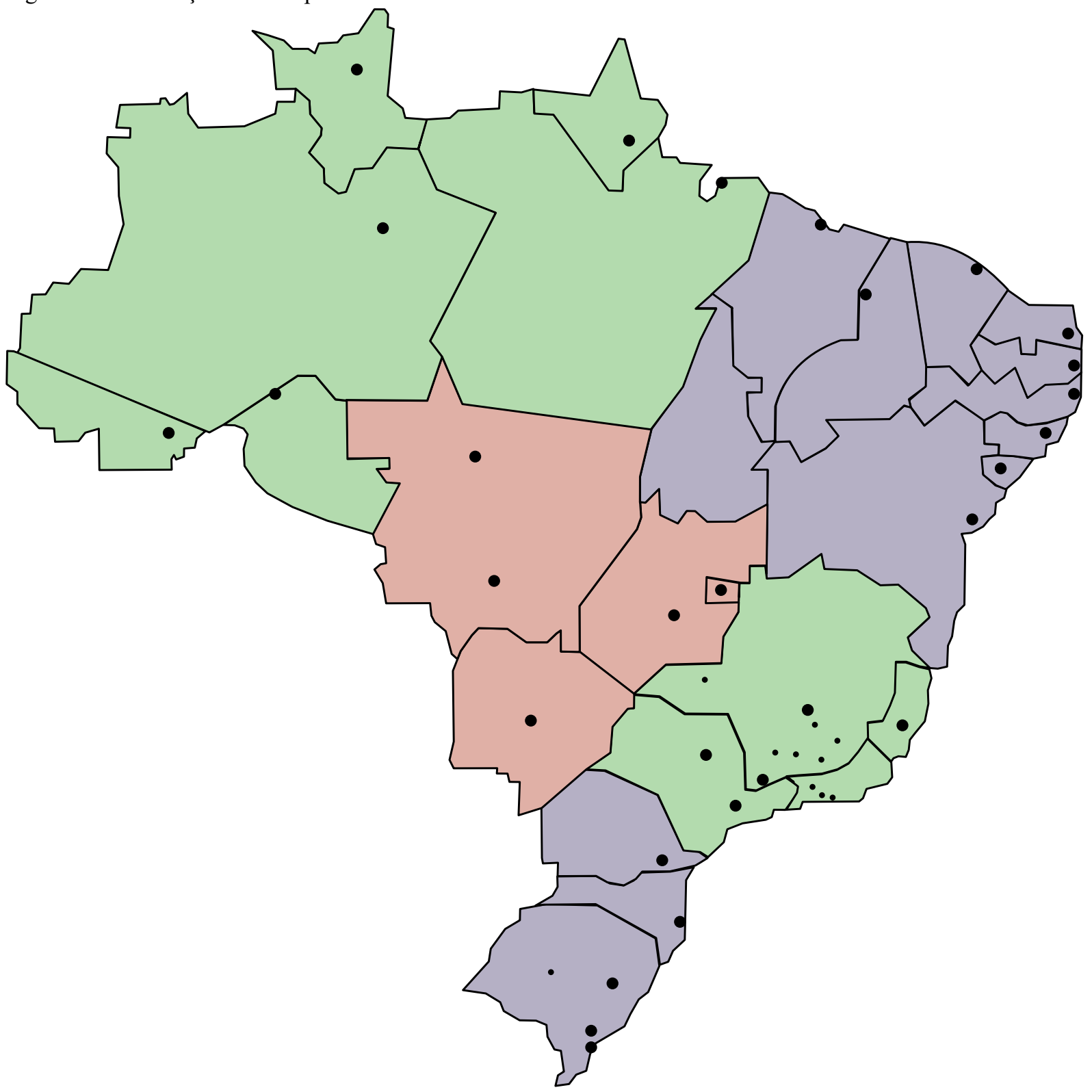

Fonte: BRITO, 2014 . Elaboração própria. 
Figura 8 - Localização dos campi das universidades federais em 2010.

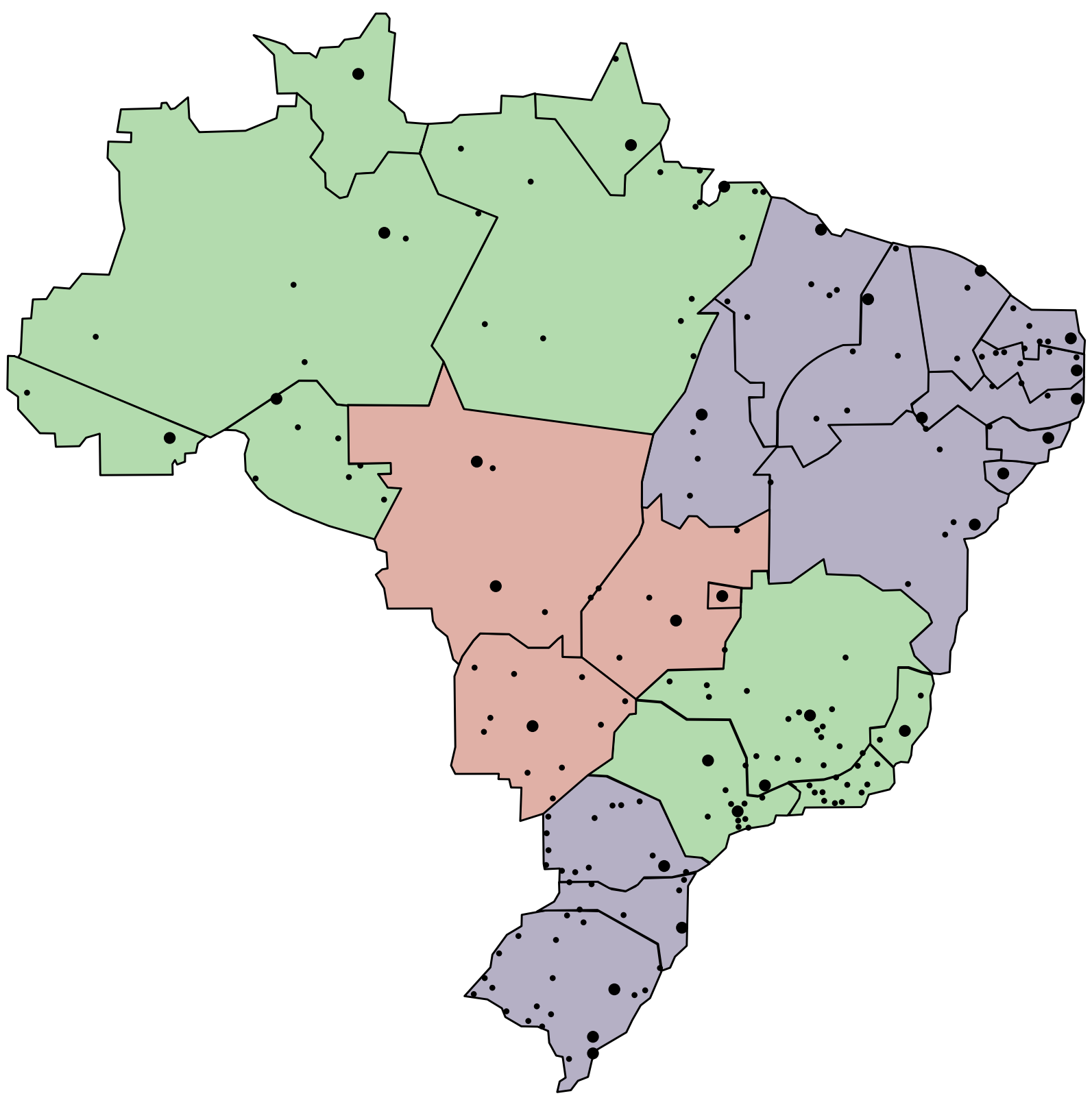

Fonte: BRITO, 2014 . Elaboração própria. 


\subsection{A relação entre desenvolvimento urbano e regional e universidades}

No Brasil, as universidades públicas têm sido direcionadas para a promoção do desenvolvimento regional desde a década de 1950 (BRÜNE, 2015a). Este papel foi reforçado no início dos anos 2000 quando as universidades federais foram expandidas, como já apresentado.

Essa relação entre as universidades e o desenvolvimento regional pode ser observada sob vários prismas, sendo que o mais comum na literatura é o dos impactos no espaço urbano. Todavia, há outras colaborações da universidade que não necessariamente se manifestam fisicamente; compreende-se que através do conceito de desenvolvimento urbano e regional é possível apontar para formas mais amplas de colaboração da universidade. Por isso, verificouse as políticas de desenvolvimento urbano (PNDU) e de Desenvolvimento Regional (PNDR) em busca dos conceitos que nortearam as suas formulações.

O texto do decreto $\mathrm{n}^{\circ}$ 6.047, que instituiu a PNDR, elenca como objetivo geral:

Art. 1o A Política Nacional de Desenvolvimento Regional - PNDR tem como objetivo a redução das desigualdades de nível de vida entre as regiões brasileiras e a promoção da equidade no acesso a oportunidades de desenvolvimento, e deve orientar os programas e ações federais no Território Nacional, atendendo ao disposto no inciso III do art. 3o da Constituição. (BRASIL, 2007. Grifo do autor)

Destaca-se o uso da expressão "níveis de vida" que, de acordo com o sumário executivo da $\mathrm{PNDR}^{10}$, pode ser traduzido por índices de avaliação, como a distribuição e o crescimento populacional, o nível de educação, o grau de urbanização, o rendimento domiciliar médio e o dinamismo econômico. Desta forma, pode-se compreender que, para a PNDR, o desenvolvimento regional é relativo à melhoria dos índices sociais e econômicos no território nacional.

Já a PNDU, segundo seu sumário executivo, "trata da inserção das cidades na dinâmica regional e no território nacional." (BRASIL, 2004, p. 08) e apresenta como definição de "desenvolvimento urbano" a

melhoria das condições materiais e subjetivas de vida nas cidades, com diminuição da desigualdade social e garantia de sustentabilidade ambiental, social e econômica. Ao lado da dimensão quantitativa da infra-estrutura, dos serviços e dos equipamentos urbanos, o desenvolvimento urbano envolve também uma ampliação da expressão social, cultural e política do indivíduo e da coletividade, em contraponto aos preconceitos, a segregação, a discriminação, ao clientelismo e a cooptação. (BRASIL, 2004. p. 8). 
Ainda assim, a PNDR ${ }^{11}$ não faz articulações com a PNE, ou seja, não dirige a política de expansão das universidades para a promoção do desenvolvimento regional. Portanto, apesar da PNE definir como um de seus objetivos o desenvolvimento regional não há previsões de como isso deveria ocorrer, nem como as universidades federais deveriam agir para tanto.

Assim, optou-se por um entendimento das questões de "desenvolvimento" e de "desenvolvimento urbano e regional" que ampliassem a compreensão das possibilidades de atuação das universidades para o desenvolvimento regional. Por isso, verificou-se o debate acerca das definições desses conceitos, como apresentado a seguir.

Uma avaliação de diversos conceitos que "desenvolvimento regional" teve ao longo do último século foi feita por Madureira (2015), as teorias elaboradas ao longo do último século, acerca deste conceito, consideram "que considera que "As principais teorias que abordam esse tema embasam-se na industrialização como o meio para atingi-lo [o desenvolvimento regional], através de relações em cadeia, visando impulsionar as principais atividades econômicas da região atingida" (2015, p. 8). Ou seja, a ideia é que ao industrializar-se, uma região aumenta os níveis de emprego e, portanto, de renda, ativando, consequentemente, o resto da cadeia, como o comércio e os serviços. Logo, deste ponto de vista, o crescimento das atividades produtivas é a condição principal para o desenvolvimento regional, já que tudo dele deriva.

Nesse mesmo sentido estão as diversas concepções de desenvolvimento regional apresentadas por Lima (2006) e Oliveira (2002). Seus estudos citam como principais teóricos Walt Whitman Rostow, Gunnar Myrdal e François Perroux, para os quais o desenvolvimento regional é um ponto no espaço, isto é, em um tempo futuro, deverá ser uma meta e, portanto, se ocupam de teorias para atingi-lo.

Esta ideia fica mais explícita com as explicações de Furtado (1980) sobre "desenvolvimento", que é parte de uma corrente teórica que considera a economia como um todo sobre a organização de uma sociedade, ou seja, não avalia apenas o crescimento das atividades produtivas ou da industrialização.

11 Entre 2011 e 2013 a PNDR passou por uma avaliação e revisão, chegando a uma proposta de formulação nova que tornava mais clara as relações da PNDR com planos setoriais, dentre eles o de educação e de ciência, tecnologia e inovação. Essa proposição tornou-se o projeto de lei n 375 de 2015 no Senado e constava como em tramitação em 17/10/2018. Cabe acrescentar que, de acordo com o site do Senado Federal, não houve tramitação do processo após o golpe parlamentar de 2015 até 28/06/2018. Disponível em: <https://www25.senado.leg.br/ web/atividade/materias/-/materia/121877>. Acesso em 17/10/2018. 
Para o autor, "desenvolvimento" é a transformação das bases produtiva e social de forma ampla e abrangente ou, em outras palavras, as transformações pelas quais uma sociedade passa. Sua concepção de economia abrange as atividades produtivas, mas também as condições sociais sob as quais elas ocorrem, ou seja, a ordem social é parte da economia, o que permite a Furtado trabalhar com o conceito de "desenvolvimento" per si, fazendo com que sua teoria abarque outras terminologias, como desenvolvimento econômico, social, sustentável, entre outras.

Diferentemente de Furtado, na bibliografia há distintas terminologias para se referir a aspectos do desenvolvimento, como "desenvolvimento econômico", "desenvolvimento social" e "desenvolvimento sustentável”. Acredita-se que em um primeiro momento isso possa auxiliar a análise de eventos e dados, porém acredita-se que pode tornar oculta ou opaca a relação que os diferentes aspectos estabelecem entre si.

Furtado (1980) torna claro o conceito que tinham os teóricos do desenvolvimento regional, apresentados acima por Lima (2006), Oliveira (2002) e Madureira (2015). De acordo com Furtado, o "desenvolvimento" é, para aqueles autores, uma condição futura, relativa ao padrão de consumo de uma sociedade, que toma como base o padrão dos países da Europa Ocidental, dos Estados Unidos e do Japão, traçando, a partir disso, um percurso que os países e as regiões deveriam percorrer.

Desta forma, torna-se evidente a preocupação dos teóricos do desenvolvimento regional de explicitarem ou o porquê das desigualdades regionais ou de definir como aquelas regiões subdesenvolvidas poderiam desenvolver-se, o que também está contido na PNDR.

Apesar disso, Furtado não territorializa seu conceito. A apropriação do conceito de "desenvolvimento" e sua territorialização se faz com o apoio da teoria de Villaça (2015) de que a uma estrutura social corresponde não só uma racionalidade produtiva, mas também a organização do espaço urbano. Em outras palavras: a apropriação do produto do trabalho social - o espaço urbano - é relativo à ordem social, exatamente como Furtado (1980) preconiza sobre a questão econômica.

Por isso, para este estudo optou-se por trabalhar com o conceito de Furtado (1980), aplicado à uma região e ao espaço urbano, de forma que se pretende destacar quais aspectos, a princípio separados, são, na verdade, íntimos. Por exemplo: há uma relação muito próxima entre a formação do espaço urbano e o nível de escolaridade da população, porque a ordem social 
a que estamos submetidos relaciona escolaridade com tipos de vagas de empregos e, portanto, com salários, e isso está diretamente ligado ao acesso à moradia e à cidade.

Por tratar de organização do espaço, uma das questões que mais se evidencia no contexto brasileiro é justamente a da apropriação do solo urbano, que se traduz em segregação socioespacial. Os benefícios do trabalho social são apropriados de forma desigual de tal maneira que uma parte importante da população esteja à parte, impossibilitada de ter acesso àquilo que foi produzido socialmente, desde sua infraestrutura até seus equipamentos. Assim, produz-se desigualdades nas condições de vida, que têm origem no acesso à propriedade e nas diferenças de níveis de escolaridade, de gênero, de cor de pele, entre outros.

Em suma, pode-se compreender o "desenvolvimento urbano" como a transformação do espaço urbano, relativo à ordem social, à organização do espaço, à provisão de infraestrutura e equipamentos, à oferta de trabalho e serviços, bem como à qualidade do espaço.

Assim, é possível vislumbrar que a colaboração das universidades para o processo de desenvolvimento urbano e regional é mais ampla do que os seus impactos diretos sobre o espaço urbano. Dessa relação, o que se procura são as formas como a universidade se porta como um agente de transformações. Logo, interessa compreender de que modo a universidade pode participar de transformações nas escalas urbana e regional.

A visão mais comum da participação da universidade no desenvolvimento regional é a sua capacidade de produzir conhecimento técnico. Isso significa que haveria crescimento ou transformação das atividades produtivas induzidas pelo conhecimento produzido pelas universidades (ou em conjunto com elas), motivadas pelo desenvolvimento das técnicas e da inovação. Estes ganhos seriam socialmente distribuídos, principalmente pela elevação dos níveis de emprego.

Todavia, nem sempre o desenvolvimento técnico caminha passo a passo com o aumento dos níveis de emprego, do aumento das atividades produtivas e do excedente. Por consequência, são apropriados de forma de desigual, o que limita as possibilidades de ganhos socialmente distribuídos.

Nesse sentido, Vieira (2017) considera que a consolidação da chamada "economia do conhecimento", aquela com aplicação intensiva da inovação e do conhecimento técnico, tem alterado os padrões de acumulação e de reprodução de riqueza. É assim que as universidades 
têm sido consideradas nas últimas décadas ao redor do mundo, indo ao encontro da opinião de Mancebo et al (2015), para quem a expansão do ensino superior

ocorre no mesmo diapasão e para o atendimento das mudanças contemporâneas ocorridas na produção e valoração do capital, a reestruturação produtiva, que teve seu início sistematizado, no Brasil, a partir da década de 1980, e, em segundo lugar, toma impulso e ganha organicidade a partir da reforma gerencialista do Estado brasileiro, posta em movimento em 1995. (MANCEBO et al, 2015, p. 35)

E complementa:

Pode-se dizer, mesmo, que as universidades públicas ocupam cada vez um papel mais destacado no processo de produção de conhecimento-mercadoria, isto é, aquele que, tornando-se tecnologia e inovação tecnológica, agrega maior valor aos produtos consumidos no mercado interno ou para exportação. (MANCEBO et al, 2015, p. 35)

Além disso, Vieira (2017) recorre ao estudo de Mille (2004) $)^{12}$, que busca definir as externalidades produzidas pelas universidades a partir de dois tipos de encadeamentos da universidade em seu contexto: para trás e para frente ("backward linkages" e "forward linkages"). Os primeiros são relativos aos fluxos monetários gerados pela universidade, tanto pelo seu consumo próprio quanto por aqueles de seus estudantes, docentes e técnicos, que gerariam impacto sobre a renda e sobre o emprego a nível local, beneficiando as empresas, que se expandiram devido à maior demanda.

Já os encadeamentos para frente são aqueles com origem na produção e na disseminação de conhecimento que podem provocar transformações estruturais nas bases produtivas de uma região. Estes seriam atributos emprestados à região que a tornaria mais atrativas às empresas e aos investimentos, aumentando os níveis de produção e de emprego, com efeitos em cascata, o que se relaciona com a visão de que a universidade contribui, sobretudo, para alterações nas atividades produtivas.

Os encadeamentos para frente podem ser ampliados, atingindo questões sociais a partir de iniciativas e equipamentos como bibliotecas, museus, galerias, centros culturais, teatros, etc. (VIEIRA, 2017). Desta forma, a universidade pode ser um agente importante de indução de transformações sociais.

Nesta seara, Baumgartner (2015) lembra, ainda, que a universidade pode inserir novas personagens ao contexto urbano, como professores e estudantes universitários, assim como ser

12 MILLE, M. The university, knowledge spillovers and local development: the experience of a new university. Higher Education Management and Policy, v._16, n. 3, p. 89-113, 2004. 
o foco de discussões políticas e culturais que se disseminem pela região, também provocando transformações sociais.

Em sentido complementar, Haddad (2009) aponta que o desenvolvimento regional pode ser decorrência da disponibilidade e da interação de "capitais intangíveis" a saber: a) capital institucional (instituições e organizações públicas e privadas); b) capital humano: estoque de conhecimentos e habilidades que possuem os indivíduos; c) capital cívico (práticas democráticas, confiança nas instituições); d) capital social (aquilo que permite laços de confiança entre indivíduos); e) capital sinérgico (capacidade de articulação dos diversos atores).

Essa ideia contraria uma impressão geral de que a simples existência de universidades induzam, por si só, o desenvolvimento urbano e regional. A influência da universidade não é uma característica intrínseca a si própria e muito menos automática. Pelo contrário, a universidade deve portar-se de tal forma que ative mecanismos que promovam transformações, de acordo com Baumgartner (2015) e Brüne (2015a).

Além disso, as relações que as universidades estabelecem não se restringem à sua região. Como o conhecimento pode ser difundido, e cada vez mais facilmente através da internet e da flexibilidade de deslocamento de capitais, as universidades podem ter relações muito mais íntimas com empresas de outras regiões do que com aquelas em que estão inseridas.

Portanto, é preciso considerar que as universidades são parte de um grupo de agentes que devem se articular. Acredita-se que é o Estado, através de uma política de desenvolvimento regional e de políticas setoriais, que tem, entre outros, o papel de articular os diversos agentes e conduzir o desenvolvimento urbano e regional. Na ausência da atuação do Estado, a partir de uma política de desenvolvimento regional articuladora, a aproximação entre universidades, empresas e indústrias fica sem propósito social claro e definido, isto é, falta a ela um sentido coletivo, regional e nacional, pois depende exclusivamente de seus interesses próprios.

Por outro lado, a ideia de Carleial e Cruz(2009), de que se crie um comitê com participação dos diversos atores, implica em um âmbito de debate sobre desenvolvimento, de forma abrangente, em que os diversos agentes podem expor suas necessidades, capacidades, interesses e intenções, que, articulados, podem induzir transformações em diversas escalas.

Além disso, é preciso reforçar que, apesar de mais citada em todos os estudos que se teve acesso, a relação universidade-empresa/indústria não é a única e nem tampouco a mais 
importante para a promoção do desenvolvimento urbano e regional. A ideia geral parte do pressuposto de que as transformações sociais dependem do crescimento das atividades produtivas e da noção geral de que o desenvolvimento regional é uma condição social e econômica futura a ser atingida pelo incremento das atividades produtivas. Mas as transformações sociais podem acontecer em paralelo às mudanças produtivas.

Por exemplo: a tomada de consciência de classe e gênero pode conduzir uma sociedade à revisão da divisão do trabalho, como já ocorreu ao longo da história, como com os movimentos grevistas do final do século XIX e começo do século XX. Essas mudanças provocam transformações do modo de produção, e de acumulação de capital.

Assim, a universidade pode ser um centro difusor dessas transformações tanto por meios formais (produção e reprodução de conhecimento - pesquisa e extensão), assim como por meios informais, como grupos ativistas e de debates.

Já quanto ao desenvolvimento urbano, especificamente, os estudos de Brüne (2015 a), Nascimento e Helal (2015) e Santana e Marengo (2012) versam sobre os impactos que diferentes universidades produziram sobre as cidades onde foram instaladas. Os impactos relatados por estes estudos são, principalmente, a expansão urbana, aumento das redes de infraestruturas, processos de gentrificação, aumento e diversificação do comércio e serviços locais.

Todavia, acredita-se que a influência das universidades sobre o contexto urbano possa ser maior de acordo com a própria acepção de "desenvolvimento urbano" que se apresentou. Pode-se questionar se a universidade participa de mudanças na constituição social da região, se ela se relaciona de alguma forma com a indução de mudanças na organização e no processo de produção do espaço, se ela demanda alterações da infraestrutura, etc.

Por fim, se reforça a ideia de que os diversos aspectos da sociedade se entrelaçam e são interdependentes, como explicado anteriormente. É preciso ter uma visão bastante abrangente da atuação da universidade e, principalmente, se considerar que o tempo é um fator de extrema importância porque transformações na sociedade podem demorar décadas para que sejam visíveis. Além disso, elas jamais serão fruto de um agente só, como a universidade, mas de diversos e da relação (desigual) que estabelecem entre si.

Assim, não se questiona quais mudanças a universidade produz ou produziu sobre uma sociedade, porque pode não ter havido tempo para que isso se tenha concretizado, como tam- 
pouco seja possível isolar um agente e atribuir a ele as transformações ocorridas. Em vez disso, é preferível observar de quais maneiras a universidade se porta e atua perante a sociedade para fazer uma leitura crítica.

\subsection{Pesquisas sobre a relação entre expansão das universidades federais e desenvol- vimento urbano e regional}

Alguns trabalhos que se identificam com a questão do desenvolvimento regional e a interiorização das universidades federais, como Jesus (2016) e Padim (2014), não tratam propriamente desse assunto, mas de algo mais relativo à área da educação em si, e foram importantes para fornecer informações a respeito das políticas públicas de expansão do ensino superior federal.

Ainda no campo da educação, destacam-se as pesquisas de BARROS (2015), Mancebo et al (2015), Gentili e Oliveira (2013), que focam sobre a questão da formulação e avaliação das políticas públicas de expansão do ensino superior, de onde extraiu-se, principalmente, uma análise crítica e dados sobre as diversas políticas, além de nos indicar os projetos de leis e as leis sancionadas.

Já no campo da relação entre universidade e desenvolvimento urbano e regional propriamente dito, destacamos os trabalhos de Santana E Marengo (2012), Baumgartner (2015), Barbosa et al (2015), Nascimento e Helal (2015), e Brüne (2015a) e (2015b). Os próximos parágrafos se aterão a estes trabalhos, tendo em vista que aqueles relativos à formulação e à avaliação das políticas públicas propriamente ditas estarão presentes em outros momentos mais oportunos.

Todos estes trabalhos têm abordagens muito diversas sobre o tema e vão desde avaliações econômicas do impacto relativo à instalação das universidades ou de seus campi, até questões mais qualitativas de como as universidades e seus campi participam do processo de desenvolvimento.

De toda forma, os trabalhos, ainda que sejam raros, pouco conexos e recentes - realizados entre 2012 e 2015 - são de extrema importância pois, como pontuou Araújo (2013), a expansão das universidades federais foi uma das principais políticas públicas de fomento ao desenvolvimento regional dos governos Lula e Dilma. 
Iniciando pelo estudo realizado por Nascimento e Helal (2015), que leva o título de "Expansão e interiorização das universidades federais: uma análise do processo de implementação do campus do litoral norte da Universidade Federal Da Paraíba”, foi importante para compreender a primeira política de expansão do governo Lula, o programa Expansão (2003-2006), que é citado em outros trabalhos mas pouco detalhado e que encontrou-se poucas informações, assim como porque é neste trabalho que se encontrou a única referência a algo de extrema importância para a análise da relação entre universidade e desenvolvimento: a relação entre os agentes envolvidos.

Segundo os autores,

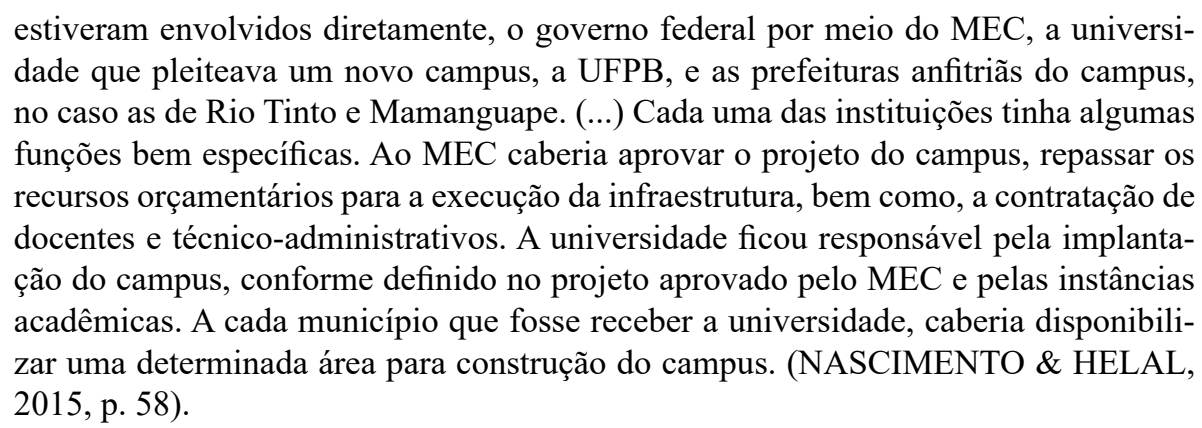

A partir de entrevistas com a comunidade acadêmica, os autores perceberam que a implementação do campus e a decisão de qual município receberia o campus passou por uma forte disputa político-partidária, que investigaram:

Depois de reuniões com parlamentares, sobretudo do PMDB partido da prefeita de Rio Tinto àquela época, a UFPB não chegou a consenso em relação a cidade a ser escolhida, e optou por um local que seria na divisa das duas cidades. A escolha de tal local, contudo, não se mostrou viável, e o campus findou por ser construído nas duas cidades [Rio Tinto e Mamanguape]. (NASCIMENTO \& HELAL, 2015, p. 61)

Para os autores, esta disputa política "justifica-se pela visibilidade que tem o campus de uma universidade em uma cidade do interior, e também para demonstrar que os parlamentares estão empenhados em trazer benefícios para a região." (NASCIMENTO e HELAL, 2015, p. 61). Relatam, ainda, que além das disputas políticas, a participação social foi decisiva para a implementação do campus e destacam os seguintes momentos como fundamentais:

1) Em agosto de 2005, quando ocorreu um encontro na cidade de Mamanguape com grande participação popular, momento que antecedeu a criação do campus; 2) Em março de 2006, quando da reunião do CONSUNI, órgão deliberativo que representou a comunidade acadêmica da universidade na matéria que discutiu e aprovou projeto de criação e implantação do campus do Litoral Norte; 3) Posteriormente, quando da participação da comunidade de Mamanguape e Rio Tinto em reuniões com gestores 
da UFPB, ocasiões em que foram discutidos diversos aspectos, como implantação de novos cursos. (NASCIMENTO \& HELAL, 2015, p. 63).

Do trabalho de Nascimento e Helal, o que chama a atenção é justamente a dimensão política do desenvolvimento, pois sabem da importância da instalação de um campus universitário para uma região, afinal, os diversos agentes se mobilizam em prol dos seus interesses particulares e coletivos. Em outras palavras: o desenvolvimento é também fruto de mobilização e disputa política. Isto é de extrema importância para não fazer parecer que desenvolvimento é fruto de boa vontade ou um processo de criação espontânea. Ao contrário, revela-se quais os agentes e disputas estão postas que esclarecem o desenvolvimento como produto social e porque ele acontece em um rumo e não em outro.

Já o trabalho de Santana e Marengo (2012), “discute os efeitos da implantação do campus da Universidade Federal do Recôncavo (UFRB) em Santo Antônio de Jesus-BA” (p. 35). A abordagem parte da apresentação da região do Recôncavo Baiano, caracterizando-a historicamente como voltada principalmente ao mercado externo, mas com importante produção voltada ao mercado interno, com ênfase na atividade extrativista. Pontua a ferrovia como fator posterior para a dinamização da região, assim como a instalação da Petrobras na década de 1950 e a modernização das rodovias, na década de 1970. Por isso, considera que "Não parece ser por acaso, portanto, a implantação de uma universidade no Recôncavo." (SANTANA \& MARENGO, 2012, p. 44), já que coincide com um processo de reestruturação regional, com uma estrutura urbana já implantada e malha urbana articulada.

Antes de adentrar na questão propriamente dita, os autores ainda fazem alguns apontamentos sobre a participação das universidades no desenvolvimento regional, sobretudo do ponto de vista de que

A instituição universidade, principalmente em tempos de agora, assume o papel fun-
damental de produzir conhecimento científico e tecnologia - informação especiali-
zada a ser incorporada pelo mercado, crescentemente globalizado -, além de formar
uma mão de obra mais qualificada para as novas exigências deste mercado. (SANTA-
NA \& MARENGO, 2012, p. 44).

Além disso, recorrem ao projeto de criação e implantação da Universidade Federal do Recôncavo da Bahia $^{13}$ à procura de informações que permitam compreender a relação entre a universidade e o desenvolvimento. É neste documento que consta a ideia da "implantação da 
universidade como uma forma de estimular o desenvolvimento regional" (SANTANA \& MARENGO, 2012, p. 44) .

Muito embora o estudo foque seus esforços sobre o município de Santo Antônio de Jesus, a UFRB distribuiu-se nos seguintes outros municípios do Recôncavo: Amargosa, Cachoeira, Feira de Santana e Santo Amaro. Segundo os autores, para o plano de implantação,

\begin{abstract}
as especificidades destes subespaços socioambientais também são indutoras da estruturação multicampi da UFRB, em que cada centro de estudo, "nas diversas áreas de conhecimento", exploraria as "culturas locais, os aspectos específicos e essenciais da população e do meio ambiente. O projeto também considera uma complementaridade entre os subespaços citados, que, de algum modo, resultaria na interação entre eles e, portanto, funcionaria como "um forte vetor contra o isolamento dos diferentes campi a serem implantados. (UNIVERSIDADE FEDERAL DORECÔNCAVO, 2003 apud SANTANA \& MARENGO, 2012, P. 46).
\end{abstract}

Assim, para Santana e Marengo, a inserção da universidade no Recôncavo liga-se à presença de atividades econômicas motrizes, aquelas capazes de gerar efeitos polarizadores. Para eles, "O Estado acredita que a presença destas universidades nas cidades mencionadas criará dinâmicas capazes de estimularem o desenvolvimento econômico (e social) nas respectivas hinterlândias.” (SANTANA \& MARENGO, 2012, p. 47), ainda que não explicitem como isto ocorre e considerem que aconteça um ajustamento das políticas públicas às condições e agentes locais.

Desta forma, os autores partem para uma série de questionamentos, muitos dos quais sem respostas, dado o estágio do trabalho naquela altura, mas que de qualquer forma são pertinentes e também indicam rumos para esta pesquisa. Dentre estes questionamentos estão: a) como foi feita a escolha do curso? Houve consulta local ou foi desapegada do território? b) Houve alguma interação com o Plano Diretor do município, de tal forma que a inserção da universidade pudesse ser parte da consecução de seus objetivos?

Por fim, Santana e Marengo pontuam que houve mudanças significativas no comércio ao redor do campus a fim de atender à demanda de estudantes, professores, técnicos e funcionários; que houve aumento no preço médio dos alugueis com a chegada das universidades e que muitos proprietários deram preferência a alugar para estudantes porque têm maior poder de compra do que parte da população; que houve concomitância entre o surgimento de condomínios fechados e a implantação do campus, sugerindo uma ligação entre os dois, com vistas a um outro padrão de urbanização motivado pela chegada da universidade, o que poderia resultar em uma urbanização de enclaves e insegura; que houve ocupação de vazios urbanos entre o campus 
e a malha urbana consolidada, sugerindo extensão das infraestruturas públicas; que a ativação do mercado imobiliário e a chegada de uma comunidade acadêmica com poder aquisitivo maior do que a população local promoveu o deslocamento de parte dos cidadãos mais pobres para outras regiões menos privilegiadas da cidade.

Segundo os autores

\begin{abstract}
a UFRB fez aumentar a pressão sobre o solo urbano nas suas imediações, visto que a universidade o valorizou. Paralelamente, aumentaram, também, os interessados em transformá-lo em valor de troca. Uma demanda aumentada faz o solo urbano se multiplicar. Casas onde moravam uma ou duas famílias tornam-se repúblicas ou pensões habitadas por vários estudantes, cuja estadia - temporária - faz criar um mercado imobiliário buliçoso e dinâmico. É nesse mesmo contexto que terrenos baldios são loteados e transformados em condomínios fechados. Os proprietários procuram se apropriar da renda de monopólio existente na(s) particularidade(s) e singularidade(s) adquirida(s) pelo bem imóvel próximo à universidade. (SANTANA \& MARENGO, 2012, p. 55).
\end{abstract}

Desta forma, entende-se que o trabalho de Santana e Marengo (2012) se preocupa com alguma definição de desenvolvimento para nortear a pesquisa mas, na prática, atentou-se mais às questões de desenvolvimento urbano do que regional.

O trabalho desses autores tem relação direta com o de Baumgartner (2015) porque a questão é semelhante, sendo que este avaliou as universidades federais na Bahia de forma ampla enquanto aqueles dedicaram-se a um recorte mais específico no campus do município de Santo Antônio de Jesus.

Baumgartner (2015) parte de algo comum aos estudos que é a busca por uma explicação da relação entre a universidade e o desenvolvimento urbano e regional, ainda que não explicite um conceito de desenvolvimento propriamente dito. $\mathrm{O}$ autor pontua que esta relação tem sua origem na década de 1960, enquanto promoção de políticas públicas, e que a universidade de fato assume papel importante na

(re)estruturação urbana e econômica das cidades (...) tanto em razão do volume de recursos financeiros movimentados quanto pela modificação de dinâmicas intraurbanas (moradia, circulação, usos etc.) e do cotidiano dos moradores. (BAUMGARTNETR, 2015, p. 75).

Para o autor,

além do impacto econômico direto através da geração de empregos públicos de alta qualificação e gastos básicos de alunos e professores, [a universidade] promove a melhoria dos padrões educacionais, qualificação da força de trabalho, avanço e desenvolvimento tecnológico e cultural. Essas características se relacionam com a forte influência que a educação tem na chamada "era da economia do conhecimento. (BAUMGARTNETR, 2015, p, 75). 
A chamada "era do conhecimento" a que Baumgartner (2015) se refere são os tempos em que vivemos já há algumas décadas. Esse conceito defende que o desenvolvimento de novos processos produtivos são fundados mais na aplicação e desenvolvimento de novas tecnologias ou design do que no produto propriamente dito. Por isso, "para atender essa demanda econômica por conhecimento, as universidades atuam muitas vezes em parceria com setores produtivos, para o desenvolvimento de conhecimento básico e aplicado para essa demanda." (BAUMGARTNER, 2015, p. 76).

Entretanto, acredita-se que "desenvolvimento"14 e seus derivados, como o "desenvolvimento regional" e o "desenvolvimento urbano", estejam ligados diretamente à técnica e à inovação, uma vez que estes dois fatores alteram a produção, permitindo que se amplie o excedente, assim como induz a mudanças no consumo e nas formas de viver, de tal modo que isto não seria de fato um destaque para os tempos atuais, mas sim uma condição das sociedades. Neste sentido, o que se coloca de diferente de outros tempos, de acordo com Silva (2014), seria a transformação de uma função social da universidade, comparada àquela de séculos passados, que passou de estar à sombra da Igreja, para estar sob tutela do Estado e em função das atividades produtivas.

Isto, para Baumgartner, pode ser observado pela relação íntima que guardam os cursos das universidades e as atividades econômicas predominantes na região. Segundo o autor, "a expansão de instituições de ensino superior pode ser compreendida como uma política de Estado, que visa dotar o território de equipamentos necessários para a participação nas atividades produtivas mais avançadas.” (BAUMGARTNER, 2015, p. 76). Também é possível verificar isso no caso do campus Diadema da Unifesp, cuja parte dos cursos de graduação e pós-graduação coincide com as principais empresas da região - farmácia, química e engenharias.

Um outro ponto importante sobre a expansão e a interiorização das universidades que o autor coloca é que isso ocorreu concomitantemente à difusão de infraestruturas a nível nacional, como a construção de rodovias, aeroportos, assim como redes de fibra-ótica e satélites. Isto é de extrema importância para inserir os municípios pequenos e médios no hall daqueles acessíveis pois, sem estas condições, a expansão para o interior se veria limitada. Nos termos de Villaça (2008), foi preciso transformar as diversas localizações, modificando seus valores de uso. Podese, a partir disto, imaginar que no caso do campus Diadema o contexto urbano também oferece forma ampla, considerando que os aspectos de ordem social são condicionantes para o modo de produção. 
alguns entraves para o desenvolvimento dada as deficiências em infraestrutura decorrentes de um processo de crescimento periférico.

Posto isto, Baumgartner (2015) avança sobre as questões práticas da inserção de universidades ou campi universitários em cidades do interior da Bahia. Sua análise conclui que, para os municípios médios e pequenos, a chegada da universidade vem acompanhada de uma comunidade acadêmica significativa, em termos populacionais e, principalmente, em termos econômicos.

O autor estima, por exemplo, que o aporte financeiro de técnicos, professores e estudantes chegasse a R $\$ 18.799 .500,00$ por ano (em valores de 2012) apenas considerando o campus Cachoeira da UFRB. Como o autor considerou para sua análise os salários base de técnicos e docentes, pode-se imaginar que este valor seja ainda maior porque a isto se somam o pagamento de benefícios, como o vale-transporte e o vale-refeição, funções gratificadas, funções de diretoria e aumentos por qualificação e progressão na carreira.

Estes dados tornam-se mais significativos quando o autor os justapõe com a realidade local:

Em Cachoeira, a renda média mensal (PNUD, 2013) per capita nos domicílios urbanos é de R\$368,12. O salário (2014) de um professor com dedicação exclusiva que possua doutorado é de $\mathrm{R} \$ 9.536,00$ e de $\mathrm{R} \$ 8.480,00$ para aqueles que possuem mestrado. Na comparação entre o salário dos professores e a renda média per capita em Cachoeira, os professores da UFRB, com mestrado ou doutorado, possuem, respectivamente, renda 23 e 25 vezes maiores que a renda média da população local.” (BAUMGARTNER, 2015, p. 87).

Para Baumgartner (2015), isto tem um impacto direto sobre a estrutura da cidade, já que dada a elevação do poder aquisitivo, sobretudo nas redondezas da universidade, o valor dos alugueis de imóveis passou de $\mathrm{R} \$ 150,00$ para $\mathrm{R} \$ 800,00$, em 2008 , o que fez com que muitas pessoas tivessem que deixar suas residências e rumar para outras áreas da cidade.

Da mesma forma, o aumento da demanda fez surgir novos loteamentos e condomínios em todos os municípios que receberam novas instalações universitárias. Este incremento de renda e de novas atividades também contribuiu para o desenvolvimento do comércio e serviço locais, com surgimento de novas papelarias, fotocopiadoras, bares, hotéis, lanchonetes, etc. e crescimento das existentes.

Soma-se a isto os aportes realizados pelo governo para a instalação e manutenção das universidades e seus campi. Para se ter ideia, o autor cita que entre 2005 e 2010 “os investimen- 
tos iniciais em infraestrutura da UFRB foram de aproximadamente R $\$ 24$ milhões, acrescidos de mais R\$ 9 milhões vinculados ao Programa Monumenta, do Ministério da Cultura, que recuperou imóveis históricos em Cachoeira." (BAUMGARTNER, 2015, p. 88). Estes valores representam grandes investimentos em infraestrutura relativos à dimensão econômica dos municípios pequenos e médios mas, mais do que isso, significam a transformação de áreas depreciadas.

Para além destas questões econômicas e urbanas, Baumgartner (2015) conduz sua análise para as transformações sociais que as universidades podem provocar. Segundo ele,

\begin{abstract}
as universidades foram importantes para o desenvolvimento das atividades culturais; seus professores escrevem nos jornais locais; e sua comunidade é frequentadora mais assídua de espetáculos culturais. Além disso, professores e estudantes contribuem para a criação e difusão de ideologias modernas e são apoiadores de diversos movimentos políticos e sociais. Por fim, aumentam a concentração de jovens nas cidades, favorecendo a difusão das discussões políticas, passando a ser um elemento essencial em todas as revoltas ou revoluções urbanas. (...) [as universidades participam da] "produção de um ambiente criativo e no fortalecimento da imagem das cidades universitárias perante as demais cidades. (BAUMGARTNER, 2015, p. 77).
\end{abstract}

Desta colocação pode-se retirar dois pontos importantes para análise. O primeiro é sobre a difusão de discussões políticas e de movimentos políticos. A segunda questão diz respeito à imagem das cidades sede de universidades ou de campi perante as demais, que vai ao encontro das políticas públicas neoliberais, que pregam a competição entre cidades de tal forma que a existência de uma universidade, ou parte dela, seja um elemento de diferenciação importante e, portanto, um atrativo de recursos e investimentos.

Além disso, o autor pontua que há transformações na base social das cidades, sobretudo nas pequenas, que se identificam com um conjunto de tipos sociais padrão (professores primários, juiz, padre) e se vem diante de novos tipos ligados à universidade: o professor universitário, o engenheiro, agrônomo, etc. Segundo Baumgartner, "as novas cidades universitárias mudam de valor e os seus próprios valores" (BAUMGARTNER, 2015, p. 87).

Por fim, Baumgartner conclui que

"um dos maiores desafios urbanos na expansão das universidades é a necessidade de se considerar as implicações decorrentes da inserção de formas novas ou renovadas em um determinado espaço, bem como da chegada de novos moradores. As características da estrutura urbana e da morfologia das cidades não podem ser esquecidas, bem como os anseios, necessidades e esperanças de suas populações nas atividades específicas que aí se desenvolvem. (...)”(BAUMGARTNER, 2015, p. 90). 
Posto isto, considera-se que o estudo de Baumgartner (2015) vai ao encontro de outros, como o de Brüne (2015) e de Santana e Marengo (2012), no sentido de avaliar os impactos da universidade no desenvolvimento urbano, com conclusões muito semelhantes: a universidade insere uma comunidade com maior poder aquisitivo que demanda novas habitações, comércio e serviços, que por sua vez mudam a estrutura das cidades em que estão inseridas, ou seja, a universidade é um agente importante na produção da cidade.

$\mathrm{O}$ autor ainda pontua que este impacto tende a ser maior nas cidades pequenas, e inclusive tende a se dissolver nas grandes cidades e nas metrópoles, dada a complexidade que possuem no momento da instalação do campus e de suas dimensões demográfica e econômica.

Por sua vez, o trabalho de Brüne (2015) intitulado de "Instituições De Ensino Superior e Desenvolvimento: O Caso Do Programa Reuni” está entre os estudos localizados que merece grande destaque porque se aproxima muito da interpretação deste estudo. Brüne se debruça nos casos dos campi Toledo da Universidade Tecnológica Federal do Paraná (UTFPR), Palotina da Universidade Federal do Paraná (UFPR), e tem como objetivo a análise de impactos destes campi em seus municípios que os faria cumprir com seu papel de contribuir para o desenvolvimento urbano e regional.

Antes de avançar, a autora retomou as questões ligadas às políticas públicas que promoveram o crescimento das universidades federais nesta entrada do século XXI, porque nelas estava explicita a intenção de promover o desenvolvimento regional a partir da inserção ou expansão das universidades.

Brüne fez um resgate sobre as formas como a universidade foi historicamente considerada importante para a promoção de desenvolvimento, tanto no contexto internacional quanto nacional, e considera que esta relação se estreitou e tornou-se explicita no governo de Juscelino Kubitscheck. Também se preocupou em verificar na bibliografia os estudos sobre esta relação e concluiu que a nível nacional são poucos e menor ainda, o número de pesquisas que tratam especificamente sobre o período pós 2003 .

Para a autora, "um debate concreto sobre o papel da educação no desenvolvimento brasileiro só começou a ser firmado a partir da década de 1980 com a interferência de agentes externos na agenda brasileira. [Banco Mundial, Banco Internacional para a Recondução e Desenvolvimento (BIRD) e a ONU]" (BRÜNE, 2015a, p. 26). Para ela 
estudos desta natureza contribuem para lançar luz sobre o desempenho das universidades como instituições que possuem um papel ativo no desenvolvimento das cidades e regiões, ampliando o debate sobre o papel da universidade e o inserindo na atual conjuntura política de redefinição das ações do Estado com relação ao incentivo (ou redução) do financiamento da educação pública. (BRÜNE, 2015b, p. 557).

Logo em seguida, diferentemente da quase totalidade dos estudos analisados, Brüne trabalha o conceito de "desenvolvimento regional" como chave para que se possa, afinal, observar os objetos de estudo e extrair deles alguns descritores. Assim, como ela, considera-se que uma análise que não tenha clareza de alguma definição de desenvolvimento não seria possível realizar uma análise pertinente. Pontua-se isto pois em muitos estudos a noção de desenvolvimento urbano e regional soa como inerente à existência de uma universidade, principalmente pública, como se a sua simples presença em um dado contexto regional e urbano bastasse. Neste sentido Brüne (2015a) chama a atenção para o fato de que

a simples existência de uma IES [Instituição de Ensino Superior] não é condição suficiente para engendrar os encadeamentos necessários para impulsionar o desenvolvimento. Ele é consequência de um esforço coletivo por parte das IES, das empresas, dos servidores, das autoridades regionais e da sociedade que devem trabalhar conjuntamente e compartilhar a responsabilidade sobre o desenvolvimento da região, analisando os cenários, identificando os problemas e usando os recursos disponíveis (BRÜNE, 2015a, p. 32).

Brüne (2015a) trabalha com alguns conceitos de desenvolvimento regional dentre os quais destacam-se os citados a partir dos estudos de Gubiani et al (2010) ${ }^{15}$, Haddad (2009) ${ }^{16} \mathrm{e}$ Ferrera de Lima (2010) ${ }^{17}$. Do trabalho de Gubiani et al (2010) a autora retira a explicação de que a universidade influencia a região onde está inserida a partir de:

i) geração de empregos diretos e indiretos; ii) prestação de serviços a comunidade (projetos de extensão universitária), iii) gastos dos alunos e funcionários. iv) investimentos da universidade, v) expansão do setor terciário e atração de novos serviços (transportes, saúde, imóveis) decorrentes do incremento populacional e; vi) formação de redes de aprendizado, inovação e empreendedorismo (BRÜNE, 2015a, p. 32).

De Haddad (2009) a autora extrai o conceito de "capitais intangíveis", aqueles que são a força motriz para o desenvolvimento regional que, resumidamente, são:

15 GUBIANI, J.S; MORALES, A. B. T; SELIG, P. M; LOPES, L. F. D. Atividades das universidades e o impacto no desenvolvimento regional. XXX ENCONTRO NACIONAL DE ENGENHARIA DE PRODUÇÃO - Maturidade e desafios da Engenharia de Produção: competitividade das empresas, condições de trabalho, meio ambiente. São Carlos, SP, Brasil, 12 a 15 de outubro de 2010

16 HADDAD, Paulo R. Capitais intangíveis e desenvolvimento regional. Revista de Economia, (set-dez de 2009). p119-146.

17 FERRERA DE LIMA, J. Integração e Desenvolvimento Regional: Elementos Teóricos. Ideação (Unioeste. Impresso), v. 12, p. 09-20, 2010. 
“i) capital institucional (malha de organizações públicas e privadas e seu poder de articulação); ii) capital humano (estoque de conhecimento dos indivíduos); iii) capital cívico (práticas sociais de cunho político e democrático que demonstram o interesse da população com os assuntos públicos); iv) capital social (cooperação mútua e formação de grupos sociais coesos) e; v) capital sinergético (capacidade real e potencial de articulação da sociedade).” (HADDAD, 2009 apud BRÜNE, 2015a, p. 37).

A autora complementa o conceito de Haddad somando-lhe a noção de "capital humano" que para Ferrera de Lima (2010) apud Brüne (2015a, p. 38) é a “capacidade produtiva e intelectual que o indivíduo adquire devido ao acesso e acumulação de conhecimentos”. Desta forma, Brüne considera que "é correto inferir que as cidades e regiões que possuem um sistema educacional bem estruturado estão mais aptas a se desenvolverem rapidamente e a manterem um desenvolvimento sustentável, no longo prazo. ” (BRÜNE, 2015a, p. 39).

Além do conceito de "desenvolvimento regional", Brüne tangencia o de "desenvolvimento urbano", o que de forma geral conclui como sendo as modificações da infraestrutura, com destaque àquelas ligadas ao deslocamento das pessoas que permitem a execução dos diversos trabalhos sociais e a reprodução da vida.

Tanto ao tratar de "desenvolvimento regional" quanto de "desenvolvimento urbano" entende-se que Brüne deixa implícito que lhe interessa mais o urbano do que o regional, apesar das políticas públicas versarem mais abertamente sobre a questão regional - tomada em várias escalas - do que sobre a urbana.

Por esta orientação, a autora é clara na sua caracterização dos municípios em questão, Toledo e Palotina, e não se ocupa de uma caracterização da região. Mais adiante, sua análise diz respeito diretamente à escala dos municípios e à do entorno imediato dos campi analisados. Segundo Brüne,

os municípios de Palotina e de Toledo estão localizados na região oeste do estado do Paraná. A proximidade geográfica dos dois municípios é de cerca de 50 quilômetros. De acordo com o Censo Demográfico (IBGE, 2010) residem em Palotina 28.683 habitantes, sendo considerado um município de "pequeno porte" pela classificação das cidades do IBGE. Em Toledo, o número de habitantes é de 119.313, sendo considerado um município de "médio porte. (BRÜNE ,2015b, p. 546).

Cabe, neste ponto, diferenciar os casos do estudo de Brüne do caso presente. Ambos os municípios, Palotina e Toledo, não são parte de uma região metropolitana e, como ela mesma pontua, podem ser considerados de pequeno e médio porte. Já Diadema, considerando-se apenas o município, são 406.718 habitantes (IBGE, 2010), e mais de 2 milhões acrescentando a re- 
gião do ABC (Santo André, São Bernardo e São Caetano), ou seja, se analisa uma população 70 vezes maior do que a do município de Palotina, e 16 vezes maior que a do município de Toledo.

Assim, o que pode ser significativo em termos de impactos diretos para os municípios paranaenses pode ser insignificante para Diadema e região, como já havia chamado a atenção o trabalho de Baumgartner (2015) sobre a diferença entre cidades pequenas e grandes. Em outras palavras, a análise de Brüne sobre os gastos realizados pela comunidade acadêmica nos municípios sede dos campi não cabe para este estudo porque se demonstraria diluído mas, ainda assim, julga-se que seja importante para este estudo desenvolver tal ideia.

Na sequência, Brüne (2015b) conclui que em Palotina, na média, cada estudante gasta por mês ${ }^{18} \mathrm{R} \$ 798,21$, cada docente $\mathrm{R} \$ 3.475,56$ e cada técnico administrativo $\mathrm{R} \$ 2.472,10$. Já em Toledo esses valores são, respectivamente, $\mathrm{R} \$ 908,79, \mathrm{R} \$ 4026,61$ e R \$2909,87. Segundo a autora, os principais gastos das três categorias são com moradia e alimentação, de forma que se pode supor que houve uma ativação do mercado imobiliário em função da instalação de ambos os campi. Esta hipótese condiz com percepção da comunidade acadêmica, mas não foi confirmada pela autora, pois a avaliação se deu apenas através de entrevistas.

Os valores citados acima são expressivos para os casos em questão, mas são praticamente irrisórios considerando-se economias industrializadas que movimentam bilhões de reais todos os anos, como é o caso da região do ABCD (Santo André, São Bernardo, São Caetano e Diadema). Além disso, por se tratar de um campus inserido em uma metrópole, em Diadema ainda há uma possibilidade muito maior de que a sua comunidade resida em outros municípios. Por outro lado, de acordo com Brüne (2015a), em Toledo, dos 879 discentes, 418 são oriundos do próprio município, 322 de outros municípios do Paraná e os demais 89 advindos de outros estados. Já em Palotina, dos 1.196 estudantes, 422 são do próprio município, 469 de outros municípios do Paraná e os demais 85 são de outros estados Brüne (2015a).

Já na segunda parte do estudo de Brüne (2015a), a partir da compreensão de que "as instituições de ensino superior podem ser consideradas grandes sistemas sociais ao se engajarem em ações que beneficiam o setor produtivo e a comunidade." (BRÜNE, 2015a, p. 103), a autora avaliou o envolvimento da comunidade com a pesquisa e a extensão, que seriam as formas mais propriamente ditas de relação com o universo que circunda as universidades; e concluiu que pesquisa, 16,3\% de extensão e 12,7\% em demais projetos sociais." (P. 105) (...) "Fo- 
ram identificados 234 projetos de pesquisa e 43 projetos de extensão em andamento. Pelos títulos dos projetos verificou-se que a maioria visa o desenvolvimento da pesquisa/extensão na área de ciências agrárias, em consonância com a demanda por inovações no setor do agronegócio regional.” (BRÜNE, 2015b, p. 106).

\title{
Já na UTFPR
}

\begin{abstract}
"Dos 383 alunos que responderam o questionário, 18,5\% estavam envolvidos com projetos sociais; $17,2 \%$ com projetos de pesquisa e $8,6 \%$ com projetos de extensão." (P.105) (...) "o levantamento de dados identificou 55 projetos de pesquisa em andamento, conseguiu-se identificar apenas os projetos iniciados no ano de 2013 até o início de 2014 (UTFPR, 2014e). Somaram-se 58 projetos de extensão.” (BRÜNE, 2015b, p. 107).
\end{abstract}

A partir disto, a autora cita alguns dos programas de pesquisa e extensão sem aprofundar-se muito sobre eles. É o caso do "Programa de Empreendedorismo e Inovação" (PROEM), do "Hotel Tecnológico da UTFPR" e do Setor de Estágios da UTFPR. Todos eles, de alguma forma, para a autora, "podem auxiliar no impulso ao desenvolvimento local. Ainda que o desenvolvimento de tais projetos, muitas vezes, seja motivado pela oportunidade de acesso a programas públicos de financiamento, o resultado continua sendo positivo para a comunidade." (BRÜNE, 2015a, p. 108).

Como síntese das questões abordadas pela pesquisa e considerando os estudos que realizou sobre desenvolvimento e a expansão das universidades, Brüne (2015a) elaborou o quadro a seguir (figura 9) em que "esboça um panorama de impactos diretos e indiretos, no nível local, que podem ser imputados à existência e ao funcionamento de uma universidade." ((BRÜNE, 2015a p. 109) e que tornou "evidente como as instituições analisadas cumprem papéis nos processos de desenvolvimento" ((BRÜNE, 2015a p. 109).

Para cada um dos quadrantes, Brüne (2015a) elabora um outro quadro que relaciona cada um dos pontos com os resultados que obteve da pesquisa, conforme segue. As tabelas de 2 a 5 referem-se, respectivamente aos quadrantes sobre capital humano e capital social; - dinamização da economia local e regional; Influências na demografia; e Ambiente de inovação. Em cada um deles estão listados os descritores e os resultados obtidos pela pesquisa, separados por campi.

Assim como BRÜNE (2015), compreende-se que o conceito "desenvolvimento urbano e regional" permite compreender a importância da política pública de expansão universitária, nesse contexto. Entretanto, considerando que a condição do campus Diadema é bastante diversa daquelas avaliadas nos municípios de Palotina e Toledo, e que o presente trabalho está no 
campo do planejamento urbano, enquanto o da autora no da economia, optou-se um percurso de estudo diferente.

Figura 9 - Capitais relacionados às universidades para a promoção do desenvolvimento regional.

\begin{tabular}{|c|c|c|}
\hline \multirow[t]{2}{*}{$\begin{array}{l}\text { CAPITAL HUMANO E SOCIAL } \\
\text { - Aglomeração de pessoal capacitado } \\
\text { - Formação de mão-de-obra } \\
\text { - Democratização } \\
\text { - Função humanista e social } \\
\text { - Docentes } \\
\text { - Retenção de graduandos } \\
\text { - Projetos de extensão } \\
\text { - Cooperação } \\
\text { - Permanência }\end{array}$} & & $\begin{array}{r}\text { DINAMIZAÇÃO DA ECONOMIA LOCAL E REGIONAL } \\
\text { - Atração de novos investimentos } \\
\text { - Gastos com alimentação, moradia, lazer, saúde, etc. } \\
\text { - Gastos da comunidade acadêmica } \\
\text {-Gastos com funcionamento da IES } \\
\text {-Movimentação Financeira } \\
\text {-Criação de postos de trabalho }\end{array}$ \\
\hline & UNIVERSIDADE & \\
\hline $\begin{array}{l}\text { INFLUÊNCIAS NA DEMOGRAFIA } \\
\text { - Atração de pessoas } \\
\text { - Expansão urbana } \\
\text { - Alocação de atividades no espaço } \\
\text { - Novas hierarquias e funcionalidades } \\
\text { - Imóveis atemporais }\end{array}$ & & $\begin{array}{r}\text { AMBIENTE DE INOVAÇÃO } \\
\text {-Empreendedorismo local } \\
\text { - Integração empresarial, inclusão de P\&D } \\
- \text { Empresas incubadoras } \\
\text { Aumento do nível tecnológico local e regional } \\
\text {-Produção e disseminação de conhecimento } \\
\text {-Projetos de pesquisa }\end{array}$ \\
\hline
\end{tabular}

Fonte: BRÜNE, 2015a. Elaboração própria de acordo com o original.

Tabela 2 - Capital humano e capital social

\begin{tabular}{|c|c|c|}
\hline \multicolumn{3}{|c|}{ CAPITAL HUMANO E SOCIAL } \\
\hline & UFPR Palotina & UTFPR Toledo \\
\hline $\begin{array}{l}\text { Aglomeraçấo de pessoal } \\
\text { qualificado }\end{array}$ & $\begin{array}{l}\text { i) } 100 \text { docentes ( } 40 \% \text { mestres, } \\
57,1 \% \text { doutores); ii) } 55 \text { técnicos } \\
\text { administrativos ( } 4,8 \% \text { mestres, } \\
57,1 \% \text { especialistas) }\end{array}$ & $\begin{array}{l}\text { i) } 99 \text { docentes ( } 55 \% \text { mestres, } 45,5 \% \\
\text { doutores }) \text { ii) } 56 \text { tecnicos } \\
\text { administrativos ( } 14,3 \% \text { mestres e } \\
57 \% \text { especialistas) }\end{array}$ \\
\hline $\begin{array}{l}\text { Projetos de extensão } \\
\text { (cooperaçăo e formaçăo de } \\
\text { capital social) }\end{array}$ & 43 projetos de extensảo até 2014 & $\begin{array}{l}58 \text { projetos de extensăo iniciados } \\
\text { em } 2013 \text { e ativos até inicio de } 2014\end{array}$ \\
\hline Formaçăo de mão-de-obra & $\begin{array}{l}101 \text { graduados no } 2^{0} \text { semestre de } \\
2013\end{array}$ & $\begin{array}{l}21 \text { graduados no } 2^{\circ} \text { semestre de } \\
2013\end{array}$ \\
\hline Retençảo de graduados & $\begin{array}{l}68,3 \% \text { dos alunos tém a intençāo de } \\
\text { permanecer no Estado do Paraná } \\
\text { após a graduação. }\end{array}$ & $\begin{array}{c}67,6 \% \text { dos alunos tém a intençảo de } \\
\text { permanecer no Estado do Paraná } \\
\text { após a graduação }\end{array}$ \\
\hline $\begin{array}{l}\text { Permanência (evita o } \\
\text { escoamento da populaçăo } \\
\text { jovem) }\end{array}$ & $\begin{array}{l}35,3 \% \text { dos académicos jé moravam } \\
\text { na cidade antes do ingresso na } \\
\text { instituiçāo }\end{array}$ & $\begin{array}{l}47,5 \% \text { dos académicos já moravam } \\
\text { na cidade antes do ingresso na } \\
\text { instituiçăo }\end{array}$ \\
\hline $\begin{array}{l}\text { Ampliação e democratização } \\
\text { do acesso }\end{array}$ & \multicolumn{2}{|c|}{$\begin{array}{l}\text { Adoçăo ao Sistema de Seleçăo Unificada - SISU - e Lei de cotas (Lei }{ }^{\circ} \\
\qquad 12.711 / 2012 \text { ) }\end{array}$} \\
\hline
\end{tabular}

Fonte: BRÜNE, 2015a. Elaboração própria de acordo com o original. 
Tabela 3 - Dinamização da economia local e regional.

\begin{tabular}{|c|c|c|}
\hline \multicolumn{3}{|c|}{ DINAMIZAÇAO DA ECONOMIA LOCAL E REGIONAL } \\
\hline & UFPR Palotina & UTFPR Tole do \\
\hline $\begin{array}{l}\text { Atração de novos } \\
\text { investimentos }\end{array}$ & $\begin{array}{l}26,9 \% \text { dos servidores alegam } \\
\text { perceber a expansão do setor de } \\
\text { comércio e de serviços }\end{array}$ & $\begin{array}{l}32,4 \% \text { dos servidores alegam } \\
\text { perceber a expansão do setor de } \\
\text { comércio e de serviços }\end{array}$ \\
\hline $\begin{array}{l}\text { Fortalecimento dos setores de } \\
\text { alimentação, moradia, lazer, } \\
\text { saúde, etc. }\end{array}$ & $\begin{array}{l}\mathrm{R} \$ 146.405,80 \text { no setor imobiliário e } \\
\mathrm{R} \$ 89.062,50 \text { com alimentação } \\
\text { por mês. }\end{array}$ & $\begin{array}{l}\mathrm{R} \$ 104.749,0 \overline{9} \text { no setor imobiliário } \\
\mathrm{R} \$ 69.504,25 \text { com alimentação } \\
\text { por mês }\end{array}$ \\
\hline Gastos da comunidade & $\begin{array}{l}\text { Em média, o acrescimo da } \\
\text { comunidade acadêmica gera injeção } \\
\mathrm{R} \$ 3.475,66 \text { por docente; } \\
\mathrm{R} \$ 2.472,10 \text { por técnico; } \\
\mathrm{R} \$ 798,21 \text { por aluno. }\end{array}$ & $\begin{array}{l}\text { Em média, o acrescimo da } \\
\text { comunidade acadêmica gera injeção } \\
\mathrm{R} \$ 4.026,61 \text { por docente; } \\
\mathrm{R} \$ 2.909,87 \text { por técnico; } \\
\mathrm{R} \$ 908,79 \text { por aluno. }\end{array}$ \\
\hline $\begin{array}{l}\text { Gastos com o funcionamento } \\
\text { do campus }\end{array}$ & \multicolumn{2}{|c|}{$\begin{array}{l}\text { Gastos relacionados à expansão pelo REUNI, à manutenção da } \\
\text { instituição (obras, equipamentos) e com despesas de custeio. }\end{array}$} \\
\hline Criação de postos de trabalho & \multicolumn{2}{|c|}{$\begin{array}{c}\text { Além da criação de postos de trabalho diretos (técnicos e docentes), } \\
\text { existe a criação de postos indiretos que geralmente são terceirizados } \\
\text { e empregam residentes na cidade } \\
\text { (serviços de manutenção, segurança, limpeza) }\end{array}$} \\
\hline
\end{tabular}

Fonte: BRÜNE, 2015a. Elaboração própria de acordo com o original.

Tabela 4 - Fonte: BRÜNE, 2015a. Elaboração própria de acordo com o original.

\begin{tabular}{|c|c|c|}
\hline \multicolumn{3}{|c|}{ INFLUÊNCIAS NA DEMOGRAFIA } \\
\hline & UFPR Palotina & UTFPR Toledo \\
\hline $\begin{array}{l}\text { Atração e concentração de } \\
\text { pessoas }\end{array}$ & $\begin{array}{l}1196 \text { alunos, } 100 \text { docentes e } 55 \\
\text { técnicos em agosto de } 2014\end{array}$ & $\begin{array}{l}879 \text { alunos, } 99 \text { docentes e } 56 \\
\text { técnicos em setembro de } 2014\end{array}$ \\
\hline $\begin{array}{l}\text { Expansão e melhorias } \\
\text { urbanas }\end{array}$ & $\begin{array}{l}\text { Abertura de loteamentos, } \\
\text { construções imobiliárias, } \\
\text { asfaltamento, melhorias no sistema } \\
\text { de trânsito, na iluminação pública, e } \\
\text { na saúde pública (com base na } \\
\text { percepção dos servidores) }\end{array}$ & $\begin{array}{c}\text { Abertura de loteamentos, } \\
\text { construções imobiliárias, } \\
\text { asfaltamento, melhorias no sistema } \\
\text { de trânsito, na iluminação pública, e } \\
\text { na saúde pública (com base na } \\
\text { percepção dos servidores) }\end{array}$ \\
\hline $\begin{array}{l}\text { Definição da alocação das } \\
\text { atividades no espaço }\end{array}$ & $\begin{array}{l}\text { Atração de empreendimentos no } \\
\text { entorno da UFPR: mercados, } \\
\text { padarias, livrarias, etc. }\end{array}$ & $\begin{array}{l}\text { Atração de empreendimentos no } \\
\text { entorno e alocação do Museu } \\
\text { Histórico Willy Barth e do Hospital } \\
\text { Regional no bairro onde a UTFPR } \\
\text { está localizada }\end{array}$ \\
\hline $\begin{array}{l}\text { Novas hierarquias entre } \\
\text { cidades }\end{array}$ & $\begin{array}{l}\text { Palotina tornou-se um ponto de } \\
\text { destino de estudantes pendulares } \\
\text { (33 acadêmicos) }\end{array}$ & $\begin{array}{l}\text { Toledo tornou-se um ponto de } \\
\text { estudantes pendulares (103 } \\
\text { acadêmicos) }\end{array}$ \\
\hline Imóvel atemporal & $\begin{array}{l}\text { Reabilitação do prédio do Seminário } \\
\text { São Vicenti Pallotti }\end{array}$ & \\
\hline
\end{tabular}

Fonte: BRÜNE, 2015a. Elaboração própria de acordo com o original. 
Tabela 5 - Ambiente de inovação.

\begin{tabular}{|c|c|c|}
\hline \multicolumn{3}{|c|}{ AMBIENTE DE INOVAÇÃO } \\
\hline & UFPR Palotina & UTFPR Toledo \\
\hline $\begin{array}{l}\text { Desenvolvimento de } \\
\text { pesquisas científicas }\end{array}$ & $\begin{array}{l}234 \text { projetos de epesquisa ativos } \\
\text { até } 2014\end{array}$ & $\begin{array}{l}55 \text { projetos de pesquisa iniciados } \\
\text { em } 2013 \text { e ativos até início de } 2014\end{array}$ \\
\hline $\begin{array}{l}\text { Empresas incubadoras e } \\
\text { programas de estímulo ao } \\
\text { empreendedorismo local e de } \\
\text { integração empresarial }\end{array}$ & $\begin{array}{l}\text { Criatec - Criando Soluções } \\
\text { Tecnológicas: empresa incubadora. } \\
\text { Escola de empreendedorismo e } \\
\text { inovação. Mini-usinas de } \\
\text { biocombustiveis }\end{array}$ & $\begin{array}{l}\text { Programa Comunidade Integrada na } \\
\text { Multiplicação de Conhecimentos - } \\
\text { CIMCO. Programa de } \\
\text { empreendedorismo e inovação - } \\
\text { PROEM. Hotel Tecnológico. } \\
\text { Setor de administração dos estágios. }\end{array}$ \\
\hline
\end{tabular}

Fonte: BRÜNE, 2015a. Elaboração própria de acordo com o original.

Um último estudo que se considerou, realizado por Barbosa et al (2015), analisa os impactos econômicos da instalação de novos campi a partir das políticas de expansão das universidades federais. Este trabalho contém algumas indicações e conclusões que são importantes para evitar certas distorções nas análises feitas por outros trabalhos, assim como neste presente.

O primeiro destaque é com relação à definição dos municípios que receberam os novos campi. Segundo Barbosa et al (2015),

(i) foram beneficiados com um campus aqueles municípios que já apresentavam, antes do início do programa, indicadores sócioeconômicos superiores à média; (ii) tais municípios se mantiveram em melhor situação nos anos seguintes; e, (iii) apesar disso, perceberam um aumento real da renda per capita inferior aos municípios não tratados. (BARBOSA, 2015, p. 10).

Os autores ainda chamam a atenção para o fato de que não há qualquer relação entre a definição dos municípios e o tamanho de suas economias, e que os municípios com gestão do Partido dos Trabalhadores - PT - tinham maior probabilidade de serem atendidos com novos campi.

Em seguida, as conclusões a que chega Barbosa et al (2015) justificam os resultados encontrados nos demais trabalhos já apresentados. Segundo os autores, para os municípios menores o impacto de curto prazo da implantação de novos campi se deve ao "efeito-gasto" enquanto que nos municípios maiores se deve ao "efeito-conhecimento".

O efeito-gasto ocorre a partir da elevação da demanda por produtos e serviços que é imediatamente gerada pela implantação do campus universitário. Neste sentido, a presença de uma universidade em nada se diferenciaria da presença de qualquer outro empreendimento de natureza estruturante. Os salários pagos para o corpo docente e pessoal de apoio administrativo e as despesas com suprimentos e serviços locais realizadas pela instituição, além dos gastos de visitantes e alunos de fora, alimentam o consumo local e, seguindo um mecanismo de multiplicação, retroalimentam a economia. Os gastos da universidade devem, portanto, resultar em maior dinamismo de setores do comércio, serviços e construção e implicar em algum crescimento da renda local. (BARBOSA et al, 2015, p. 2). 
Já o efeito-conhecimento possibilita

aos setores produtivos, ao setor público e a outras instituições locais melhorias em seus processos de produção e o desenvolvimento de novos produtos. (...) a elevação do capital humano da população leva a melhorias na sua produtividade, que implica em maiores retornos para si e para os negócios da região, promovendo um maior crescimento econômico no longo prazo. (BARBOSA et al, 2015, p. 3).

Portanto, a partir das conclusões de Barbosa et al (2015), podemos compreender que os resultados a que chegaram os estudos de Baumgartner (2015), Brüne (2015a) e Santana e Marengo (2012), no que se refere aos impactos de curto prazo da instalação dos novos campi, são condizentes e esperados pois, como adverte Baumgartner (2015), poderiam ser os resultados de quaisquer outros empreendimentos de tal porte. Os novos campi em cidades médias e pequenas geram impactos diretos no espaço intraurbano, mas não necessariamente nas cidades grandes e nas metrópoles.

Desta forma, o que soa como definitivamente importante é saber como as universidades de fato cumprem com a função para que foram designadas pelo Estado, ou seja, de participar dos processos de desenvolvimento urbano e regional. Como pontuaram Brüne (2015a) e Baumgartner (2015), a simples instalação de um campus não é fator provedor de desenvolvimento, pois é preciso haver mobilização e atuação conjunta de diversos agentes entre os quais a universidade se insere.

Isto não significa mensurar o impacto das universidades sobre o desenvolvimento urbano e regional porque, ainda que a universidade esteja de fato atuando neste sentido, a concretização de impactos pode ser neutralizada por outros fatores (como crise econômica, a competição com outras regiões e a capacidade da região de reter o capital humano produzido pela universidade). Assim, compreende-se que o importante é verificar como a universidade tem agido no conjunto dos agentes socioeconômicos para a promoção do desenvolvimento urbano e regional.

Neste sentido, chama a atenção o trabalho de Nascimento e Helal (2015) e a segunda parte do trabalho de Brüne (2015a). É nestes trabalhos que há aquilo que a bibliografia aponta como fatores para o desenvolvimento urbano e regional: capital humano, redes de agentes, relações com empresas, com a sociedade, com políticos, etc.

Por isso, é preciso conhecer as relações que a universidade estabelece com a sociedade de forma geral, com as empresas e industrias, e com as prefeituras da região no sentido de ofe- 
recer conhecimento, técnica e trabalho, assim como demandar transformações de infraestrutura e formular políticas públicas.

Em outras palavras: o campus pode exigir, como de fato o faz, novas linhas de transporte público ou alterações nas existentes, maior vigilância da polícia, alterações na rede pública de eletricidade, além de exercer participação direta na revisão do Plano Diretor, da mesma forma como ele pode reagir a demandas da prefeitura e do governo do Estado.

Por fim, os trabalhos analisados partem da mesma premissa, a de que as universidades produzem transformações a nível regional e urbano, ou seja, provocam desenvolvimento, independe de haver uma definição conceitual clara deste ou não.

Ainda assim, o que se verificou é que apesar de abordarem conceitos amplos e escalas diversas, os estudos reservaram a maior parte de suas atenções para as questões ligadas ao desenvolvimento urbano e, mais precisamente, aos impactos sobre o espaço intraurbano que possam ter sido provocados pela inserção da universidade, principalmente com relação ao crescimento da área urbanizada, expansão das infraestruturas, processos de gentrificação e crescimento econômico local.

Os estudos não focaram suas abordagens em questões mais amplas, que pudessem apontar para transformações mais profundas na organização do espaço urbano e regional, assim como na economia e na sociedade. Muitos deles citam estas possibilidades, mas não chegam a tratar disto como um fato, sobretudo porque mantiveram suas atenções para impactos, aquilo que fosse evidentemente causado pela expansão da universidade e pudesse ser mensurado ou observado claramente. Todavia, sabe-se que estes impactos são de difícil observação porque misturam-se a outras causas, como o próprio crescimento econômico que o país atravessou naqueles anos, assim como a falta de proximidade histórica para que muitos processos tenham tomado forma.

Assim, acredita-se que ao invés de avaliar a ponta, o resultado do processo, deve-se avaliar o meio, a forma como ele aconteceu e está acontecendo, para saber como a universidade tem se portado e participado da promoção do desenvolvimento urbano e regional. 


\subsection{Elementos e descritores para a análise do campus Diadema}

A seguir, estão sintetizados os elementos que foram destacados ao longo deste capítulo, que serviram de base para a realização da pesquisa. Um primeiro grupo de questões é relativa ao contexto sobre o qual o campus foi fundado e opera. Há um dado desenvolvimento urbano e regional que partiu de algumas premissas e condicionantes que explicam a atual configuração do espaço urbano em Diadema e suas características sociais. Isso é relativo, sobretudo, à ordem social que fundamentou a industrialização, e esta propriamente dita.

Dessa forma, cabe destacar quais eram as preexistências e o que o campus Diadema tem realizado que pode transformar esse quadro, sobretudo do ponto de vista da educação e da participação dos grupos políticos e sociais que incitam determinadas discussões e as façam ecoar para fora do campus.

Ainda nesse sentido, entende-se que, enquanto contexto, valha à pena uma retomada histórica da implantação e consolidação do campus que possa destacar sob quais bases e pretexto sociopolítico ele está se erguendo. Dessa passagem emergem as relações que o campus estabeleceu com outros agentes durante sua breve história e como ele influenciou e foi influenciado por fatores políticos externos.

No mesmo tom do contexto urbano e social, é fundamental que se discuta a importância dos impactos urbanos promovidos pelo campus porque este é um aspecto recorrente em diversos estudos apresentados. Por isso, entende-se que seja importante apresentar dados e fatores que demonstrem essa importância.

Por fim, deve-se atentar a outros elementos da bibliografia como: encadeamentos para trás e para frente, de Vieira (2017); a formação de capitais institucional, cívico, social e sinérgico, em Haddad (2009); a qualificação da mão-de-obra; a dimensão política do desenvolvimento urbano e regional e os agentes envolvidos, as forças motrizes envolvidas; a inserção de novas personagens ao contexto social, de Baumgartner (2015).

Desta forma, acredita-se que se possa demonstrar de quais formas a atuação do campus Diadema colaborou para o desenvolvimento urbano e regional, e como isso desencadeou transformações no espaço urbano e nos níveis de vida, escolaridade, cultura, etc. 


\section{DIADEMA}

O capítulo a seguir tem por objetivo apresentar a formação do espaço urbano em Diadema, suas características e dados que permitam a compreensão da sua condição social, para se entender, a partir disso, a inserção do campus da Unifesp e como ele tem colaborado para o desenvolvimento urbano e regional. Abaixo, a figura 10 mostra a divisão municipal da RMSP, em seguida, a figura 11 ressalta os municípios da região do $\mathrm{ABC}$ e a figura 12 apresenta a divisão de bairros de Diadema.

Figura 10 - Região Metropolitana de São Paulo, divisão municipal.

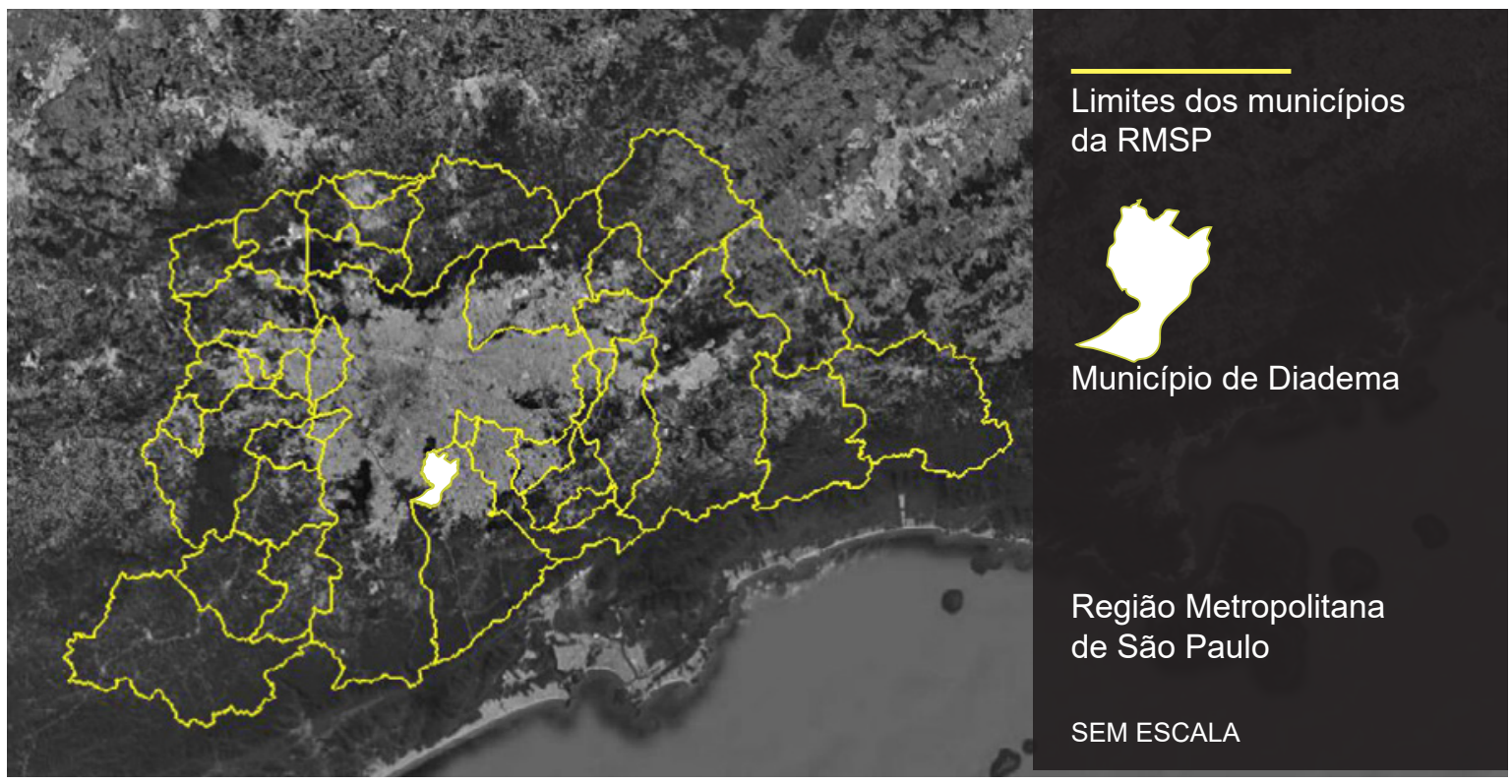

Fonte: Google Earth. Elaboração própria.

Figura 11 - Divisão municipal da região do $\mathrm{ABC}$.

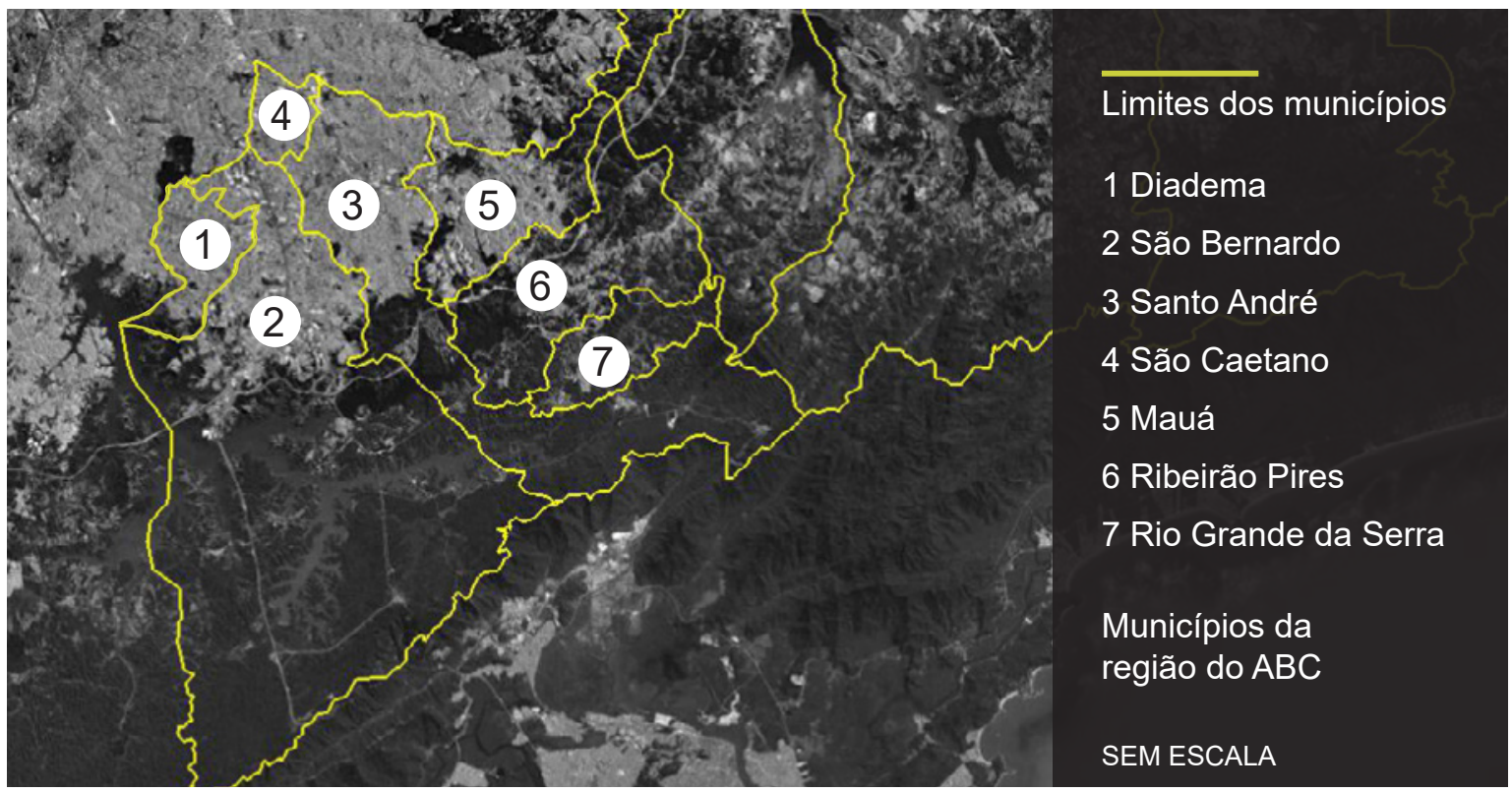

Fonte: Google Earth. Elaboração própria. 
Figura 12 - Divisão de bairros de Diadema.

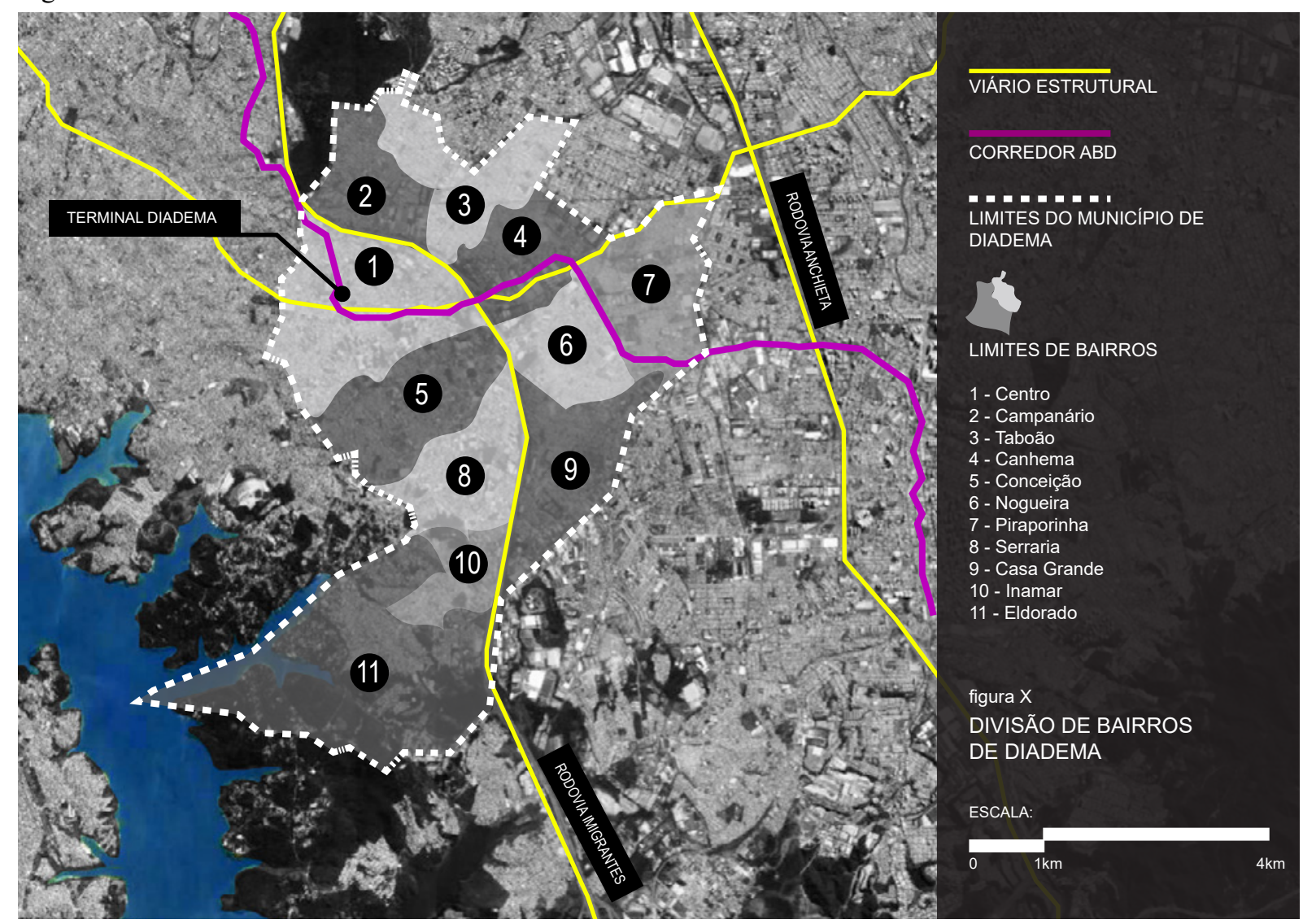

Fonte: Imagem aérea: Google Earth. Bairros de Diadema: Prefeitura de Diadema. Elaboração própria.

\section{1 - A formação do espaço urbano em Diadema.}

Diadema é um município jovem. Sua demarcação territorial aconteceu 70 anos atrás, em 1948, enquanto distrito do município de São Bernardo do Campo e sua emancipação ocorreu em 1953.

$\mathrm{Na}$ estruturação da metrópole, o espaço de Diadema foi um vazio até meados do século XX. Até então, existia uma pequena atividade econômica, baseada em madeireiras, que abasteciam as movelarias de São Bernardo e algumas olarias. No mais, era uma área de passagem entre os núcleos originais do planalto: São Bernardo da Borda do Campo (que deu origem a São Bernardo do Campo e a Santo André) Santo Amaro e São Paulo. Esses três núcleos remetem à ocupação lusitana ainda no século XVI, sendo apenas no século XIX que esses três núcleos ganharam alguma importância e cresceram dependentes da atividade cafeicultora no Vale do Paraíba,no interior do estado.

A industrialização que seguiu à cafeicultura concentrou-se ao longo da ferrovia SantosJundiaí, sobretudo entre os bairros da Mooca e Barra Funda, em São Paulo, expandindo-se para 
o noroeste e o sudeste em um segundo momento, até atingir Santo André. Vem daí a origem de alguns novos núcleos nos arredores das estações, que Langenbuch (1971) chamou de "Suburbios Ferroviários". Uma delas, a de Santo André, fez desenvolver o núcleo original e ainda impulsionou o crescimento de São Bernardo do Campo.

Neste momento, a região já contava com as linhas férreas Central do Brasil e Sorocabana, que davam outras direções para a instalação da indústria, atingindo também a região do Jurubatuba em Santo Amaro. Portanto, estavam consolidadas as localizações que têm, grande importância para Diadema: São Paulo, Santo Amaro e Santo André/São Bernardo.

A ocupação do território de Diadema aconteceu a reboque de um segundo momento de industrialização da região, após a construção da Rodovia Anchieta, em 1947. Esta nova via de acesso ao litoral foi parte da transformação do padrão de transporte de cargas em todo o país, fazendo com que a ferrovia perdesse importância ao longo dos anos e a rodovia se tornasse o principal meio de escoamento da produção.

A instalação de ruas, avenidas e rodovias é muito mais simples e barata do que a de ferrovias, assim como sua operação e manutenção. Além disso, o sistema rodoviário é capilar, ao passo que o ferroviário é axial. Dessa forma, a partir de uma rodovia é muito mais barato, rápido e simples adentrar o território do que a partir de uma ferrovia. Por isso, em um primeiro momento as indústrias localizavam-se junto à ferrovia ou muito próximas a elas, e com o sistema rodoviário foi possível que se distanciassem dos eixos principais e se espraiassem, o que explica parte da expansão horizontal da cidade.

Da mesma forma, a substituição do bonde pelos ônibus permitiu que os trabalhadores ocupassem áreas mais distantes dos núcleos urbanizados e arredores de estações de trens. A esta nova forma de ocupação de território Langembuch (1971) dá o nome de "subúrbios rodoviários", que além da ocupação horizontal, têm como característica a descontinuidade territorial, infraestrutura incompleta e poucos ou nenhum equipamento público, o que, inclusive, retardou a expansão da indústria em Diadema. A figura 13 apresenta os principais elementos estruturadores da metrópole. 
Figura 13 - Elementos estruturantes da RMSP.

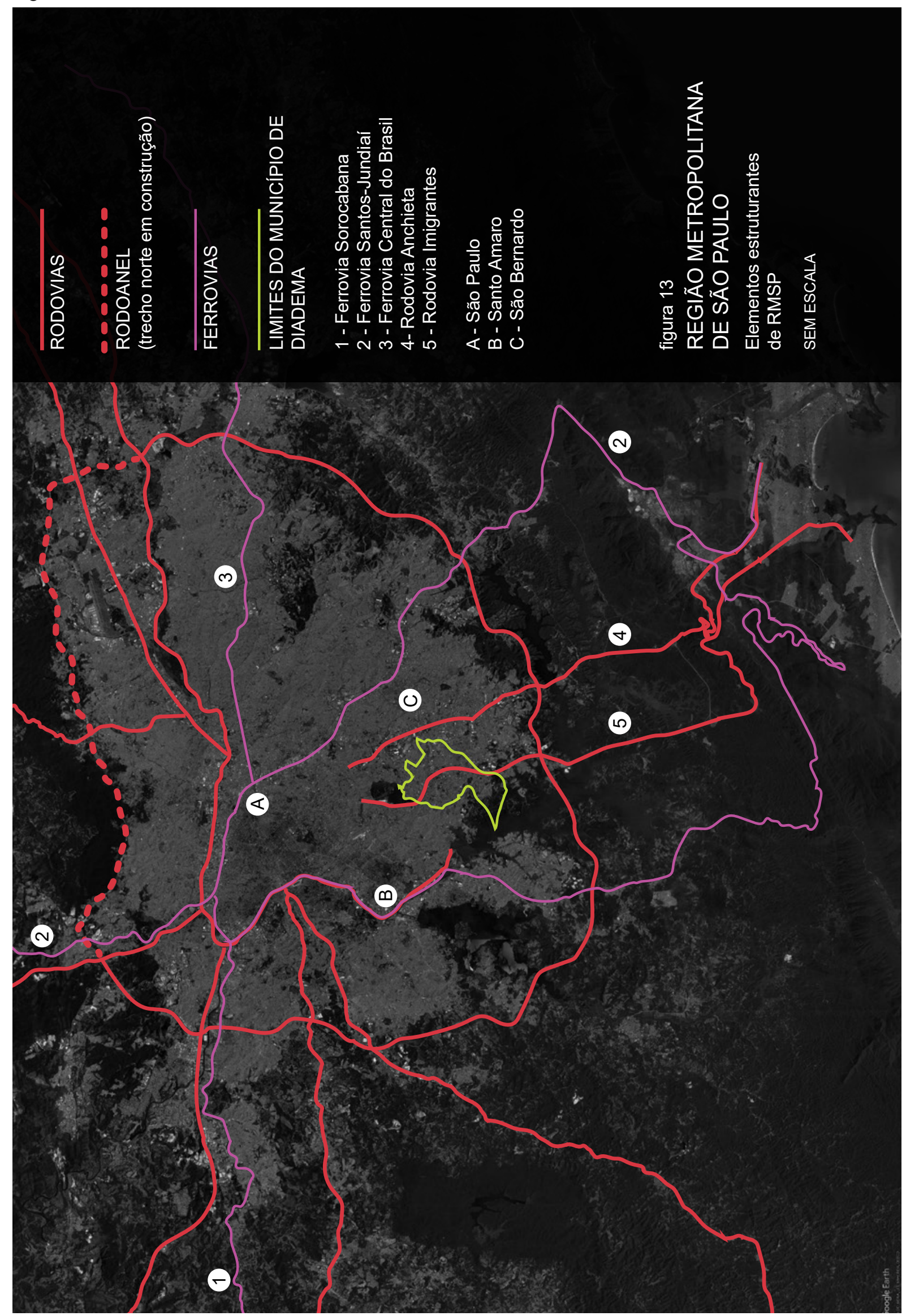

Fonte: Google Earth. Elaboração própria. 
Outro fator importante a ser considerado é que com a lei de terras, promulgada quase 100 anos antes, em 1850, a única forma de acesso à propriedade da terra é a compra. Isso tem dois efeitos importantes para a formação do território de Diadema. Em primeiro lugar, associado a um modelo de livre iniciativa e à expansão urbana, as propriedades, herdadas do período colonial, passaram a ser subdivididas e vendidas, sem uma ideia de conjunto, conformando uma imensa malha de retalhos.

Em segundo lugar, a propriedade da terra passou a ser inacessível para todos os trabalhadores porque a industrialização era, de acordo com Maricato (2017), de baixos salários. Neste sentido, havia, e ainda há, um descompasso entre o preço da terra e a renda das famílias que trabalhavam nas indústrias. A falta de uma política habitacional e, ainda, a promulgação da Lei do Inquilinato em 1940, fez com que as ocupações irregulares se tornassem a única alternativa de habitação para uma grande parcela da população. A isso se soma, também, a criação da área de preservação da represa Billings, que fez cair o valor de mercado da terra. Disto, originaramse diversos loteamentos clandestinos que se tornaram viáveis aos trabalhadores. Hoje, aproximadamente $22 \%(7 \mathrm{~km})$ são área de preservação ambiental.

As figuras 14 e 15 mostram a porção norte do município de Diademae seus arredores em 1958 e 2018, respectivamente. É possível notar que uma grande parte do território de Diadema ainda não tinha sido ocupado.

Figura 14 - Porção norte do município de Diadema e arredores em 1958.

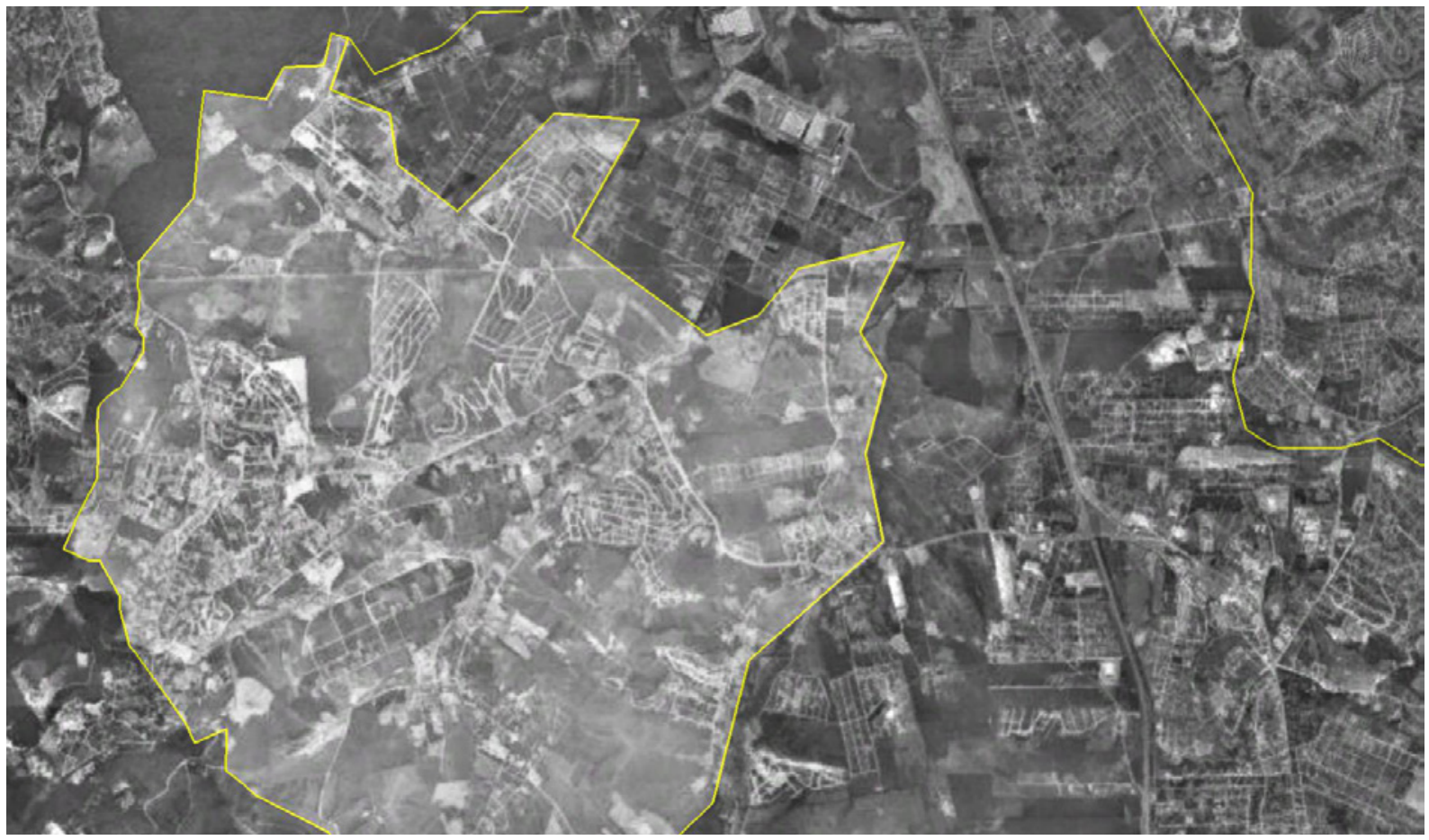

Fonte: Geoportal e Google Earth. Elaboração própria. 
Figura 15 - Porção norte do município de Diadema e arredores em 2018.

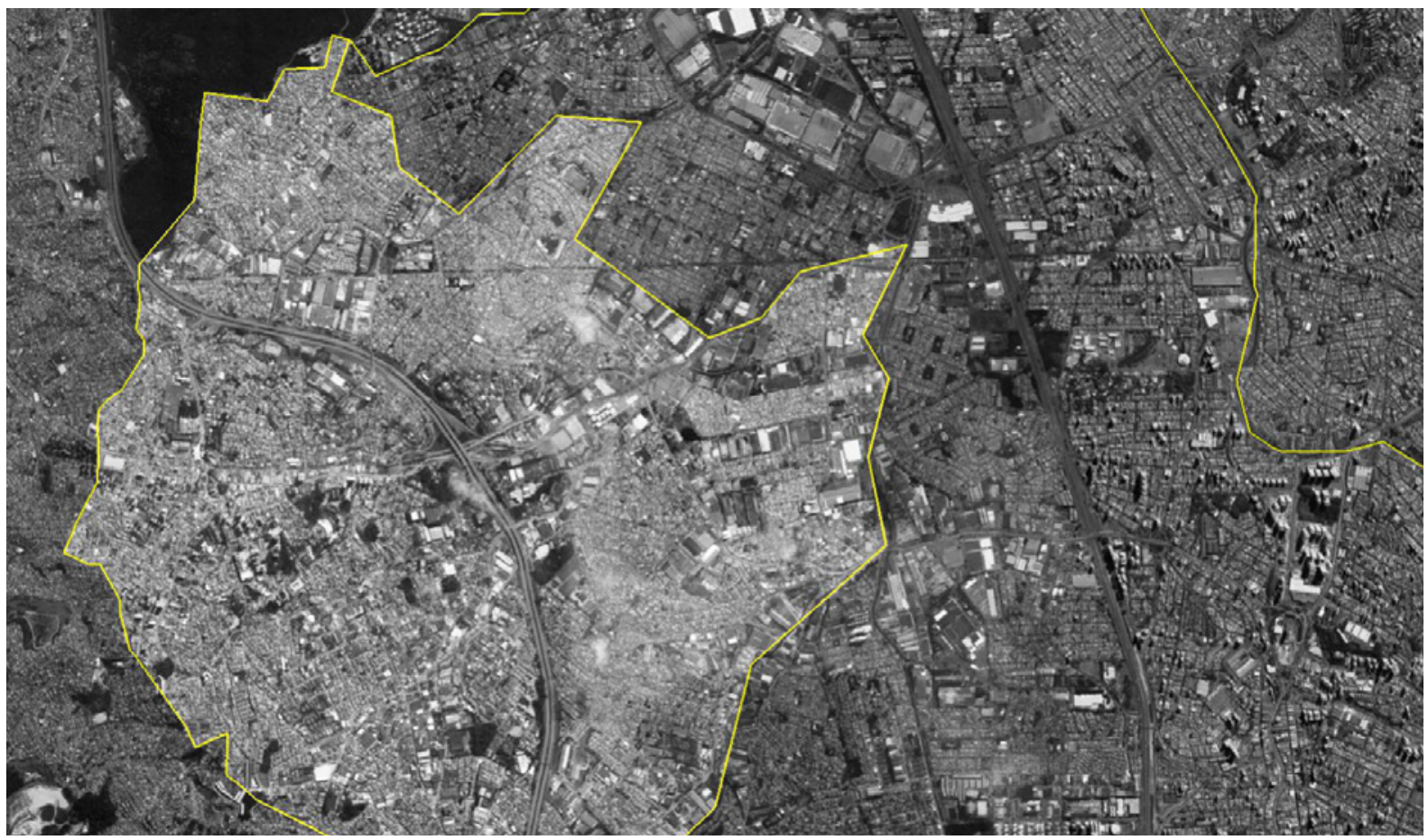

Fonte: Geoportal e Google Earth. Elaboração própria.

A industrialização, enquanto processo social, ainda teve um efeito importante nacionalmente: a migração intensa do campo para a cidade, o que fez transformar a população brasileira de rural em urbana. Assim, rumava para a cidade um contingente grande de pessoas em busca de trabalho nas fábricas, com baixa capacitação e escolaridade, sem uma alternativa viável de moradia formal.

A esse padrão de urbanização, Bonduki (1983) empresta o conceito de "padrão periférico de urbanização", marcado pela irregularidade das construções, negligência do Estado, lote urbano precário, aluguel de quarto e cortiços como alternativas predominantes para a questão da habitação. Este foi o modelo de ocupação das habitações predominante em toda a periferia da RMSP, e repetiu-se em Diadema.

Já as novas indústrias, sobretudo a automobilística, que se instalaram ao longo da Rodovia Anchieta, induziram a ocupação da porção leste de Diadema, sobretudo com habitações para os trabalhadores das indústrias do município de São Bernardo.

Pouco mais tarde, a partir da década de 1970, a descentralização industrial fez com que pequenas e médias indústrias se instalassem na órbita das grandes, rumando ao oeste. Assim, o território passou a mesclar habitações e indústrias, com pouca ou nenhuma infraestrutura. 
Segundo Santos (2006), “A primeira lei de zoneamento e uso do solo, de 1961, estabelecia que $74 \%$ da área total do município destinava-se à atividade industrial, $24 \%$ para área turística e menos de 2\% para uso residencial.” (SANTOS, 2006, p. 28). A lei de uso e ocupação de solo de 1969 manteve essa proporção (figura 16).

Nesta época, a área residencial concentrava-se no centro e foi ocupada pela população de maior renda. Esta característica se consolidou ao longo dos anos e hoje o centro é a região com maior concentração de população com rendimento nominal maior que 2 salários mínimos, como se pode verificar na figura 18.

Já “o primeiro plano diretor de Diadema (figura 17), de 1973, definiu 41\% do território para área residencial, 49,3\% para industrial, 4,9\% para comercial e 4,8\% para área turística" (SANTOS, 2006, p. 27). Para Pinheiro, na década de 1970

a população do município já se aproximava dos 100.000 habitantes,chegando à década de 1980 com população de 228.660 habitantes. Isto significa que os índices indicados no Plano Diretor correspondem às áreas já ocupadas e não à presença de uma política habitacional no município. (PINHEIRO, 2007, p.53).

Figura 16 - Lei de uso e ocupação do solo, 1969. Figura 17 - Lei de uso e ocupação do solo, 1973
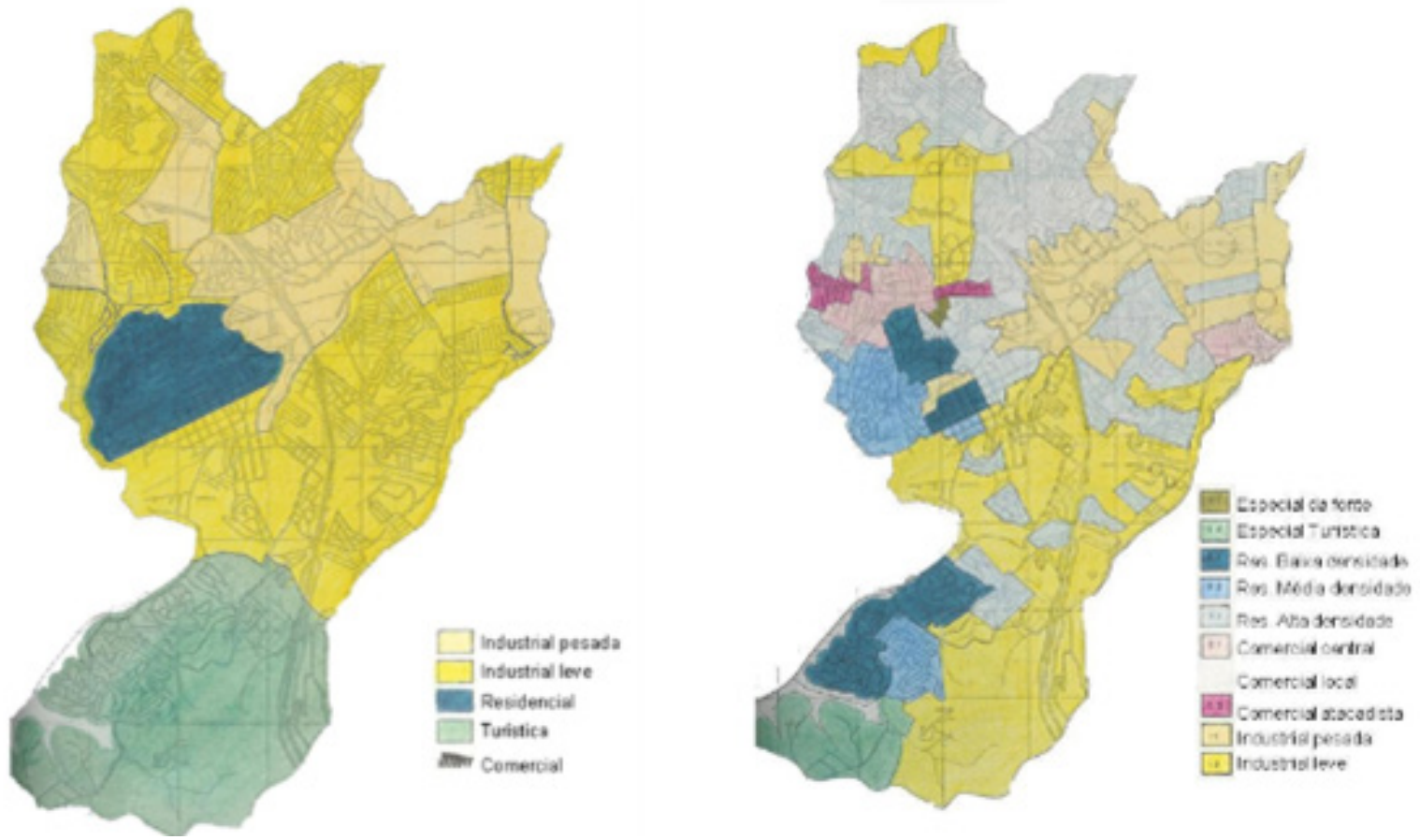

Fonte: JUNIOR, 2011.

Fonte: JUNIOR, 2011. 
Figura 18 - Percentual dos domicílios particulares permanentes por classes de rendimento nominal mensal docimiliar per capita em 2010 - Dados do universo.

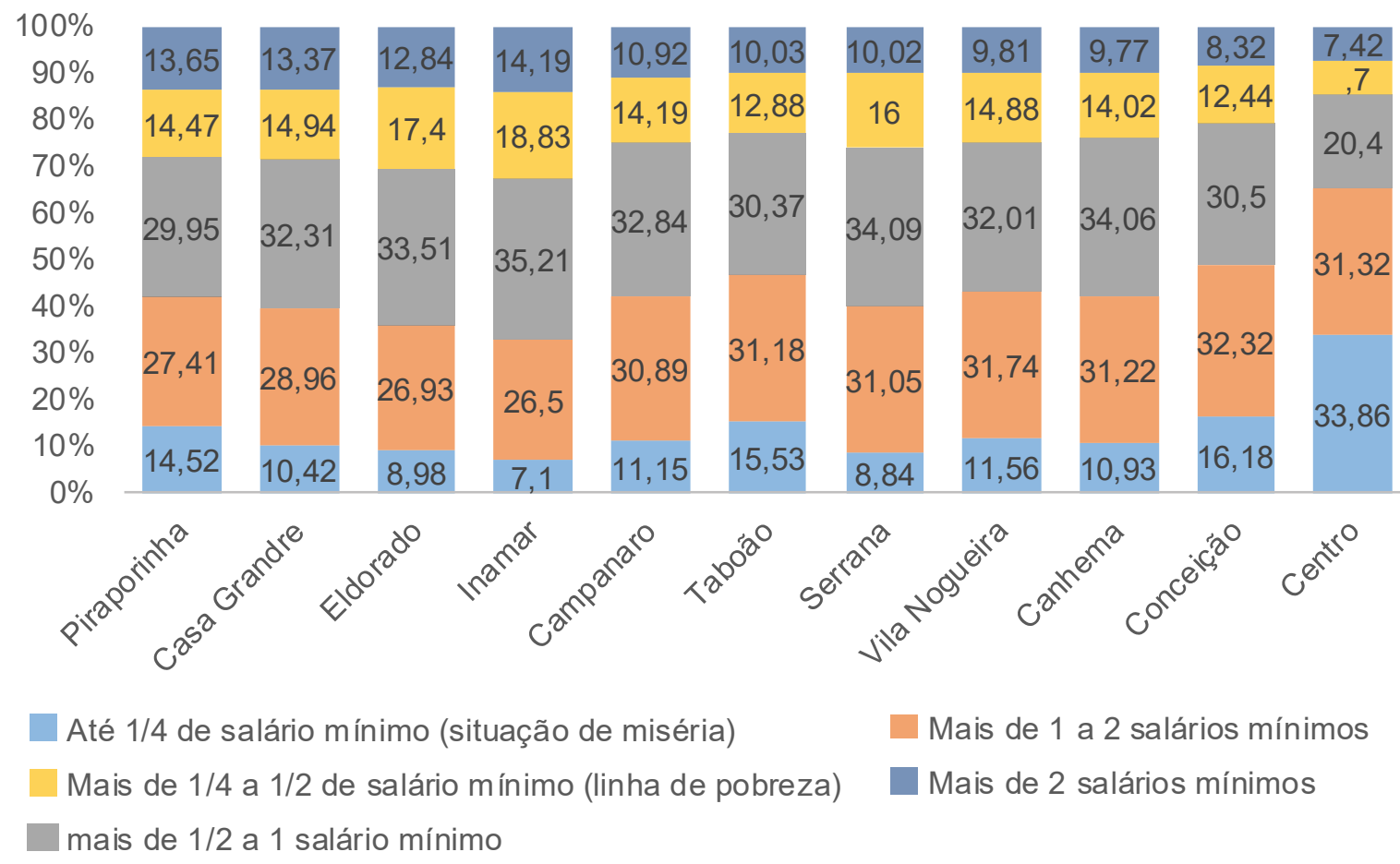

Salário mínimo utilizado $\mathrm{R} \$ 510,00$. A categoria até $1 / 4$ de salário mínimo inclui os sem rendimento cuja pessoa responsável recebia somente em benefício. Fonte: IBGE. Elaboração própria.

Esta noção apresentada pela autora vai ao encontro da opinião de Rolnik (1997), para quem as legislações de uso e ocupação de solo não são uma forma de ordenamento do território, senão um retrato daquilo que é existente no momento de promulgação da lei.

De acordo com Pinheiro (2007), Diadema entrou na década de 80 conhecida por ser uma cidade dormitório. Grande parte do seu território era carente de infraestrutura, o que inibia a expansão industrial. Para se ter noção, apenas $22 \%$ das vias eram pavimentadas e 3,5\% do território era de favelas sem urbanização.

Porém, grandes investimentos foram feitos em parceria com o $\mathrm{BNH}$, através do projeto "Cura" - Comunidade Urbana para Recuperação Acelerada". Segundo Pinheiro (2007), "no período de 1982 a 1994, a Prefeitura construiu dois hospitais municipais, 15 centros de saúde, pavimentou mais de mil ruas e urbanizou 50\% das favelas, além de realizar melhorias nas favelas restantes" (PINHEIRO, 2007, p. 54).

Este investimento massivo em infraestrutura fez modificar as localizações de Diadema e seus valores de uso, de acordo com Villaça (1998). Isso, juntamente a incentivos fiscais e a recém-inaugurada rodovia dos Imigrantes, em 1976, fez com que muitas indústrias se instalas- 
sem em Diadema, ampliando e diversificando seu parque industrial. Hoje, Diadema conta com principais ramos industriais: peças e ferramentas (ligado fortemente à indústria automobilística), fármacos, cosméticos e químicos. 23\% do território é industrial, segundo a Emplasa (2006).

Assim, foi durante a década de 1980 que o território se consolidou, com uma condição bastante precária. A mortalidade infantil era de 81,8 mortos por mil nascimentos, uma das maiores do país. A população já atingia os 230 mil habitantes, sendo que mais de um terço habitava favelas. Diadema também chegou a ser considerado um dos municípios mais violentos do Brasil, de acordo com Pinheiro (2007).

Já a década de 1990 foi bastante complicada para o município porque, apesar do investimento público, a crise econômica que o país enfrentou, combinada com novas medidas econômicas das gestões de Fernando Henrique Cardoso, criou uma imensa concorrência para a indústria nacional, sobretudo a automobilística.

Como é central para toda a região, a queda da produção das montadoras levou ao decréscimo da produção e do emprego. Em 1991, Diadema tinha 84.371 postos de trabalho, mas apenas 73.101 em 2001. Este cenário dificultou a evolução dos índices sociais. A este respeito, Pinheiro diz:

\begin{abstract}
em 1990 o país importou seis mil veículos. Este número passou para quatrocentos mil no ano de 1995, o que conduziu ao fechamento de diversas empresas e gerou grande desemprego; isto porque o governo do presidente Fernando Henrique Cardoso adotou uma política para o setor industrial, que reduz a alíquota de importação dos componentes e protege os carros acabados. No ano de 1997, a alíquota de importação de carros acabados para montadoras instaladas no Brasil era de $35 \%$ e para autopeças e matérias-primas era menor que $5 \%$. O resultado desta política foi a proteção das montadoras e o fechamento de diversas empresas de autopeças na região do Grande $\mathrm{ABC}$ e em todo o país. (PINHEIRO, 2007, p. 33).
\end{abstract}

Por outro lado, durante os anos 2000, com a retomada do crescimento econômico, a prefeitura coordenou diversas ações no campo social e da seguridade urbana, assim como no do urbanismo, que fizeram com que Diadema despencasse da primeira posição do ranking da violência.

De acordo com dados da Secretaria Estadual de Segurança Pública, houve drástica redução do total de homicídios que passou de 76/mil habitantes, em 2000 para 8,97/mil habitantes, em 2011, como indica a figura 19. Além disso, o total de mortes violentas recuou de $25 \%$ do total de óbitos em 2003 para 18,11\% em 2010. Em termos absolutos, a redução foi de 33\% no período, de acordo com dados do IBGE, conforme figura 20. 
Figura 19 - Taxa de homicídios dolosos por 100 mil habitantes em Diadema

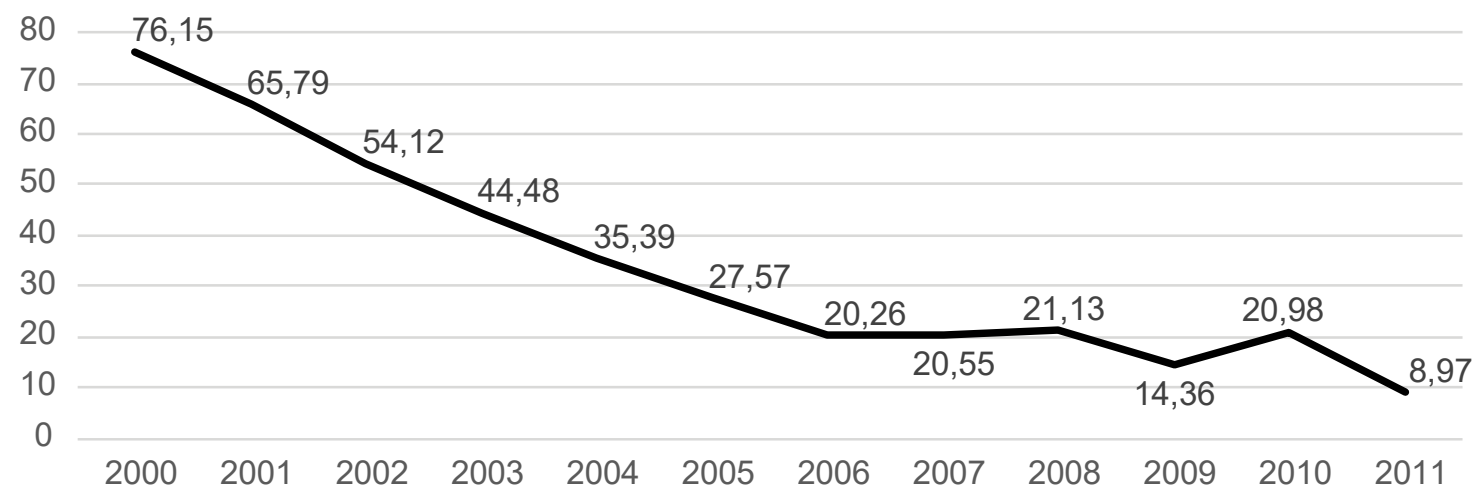

Fonte: Secretaria Estadual de Segurança Pública

Figura 20 - Óbitos totais e por natureza do óbito em Diadema, por lugar de registro

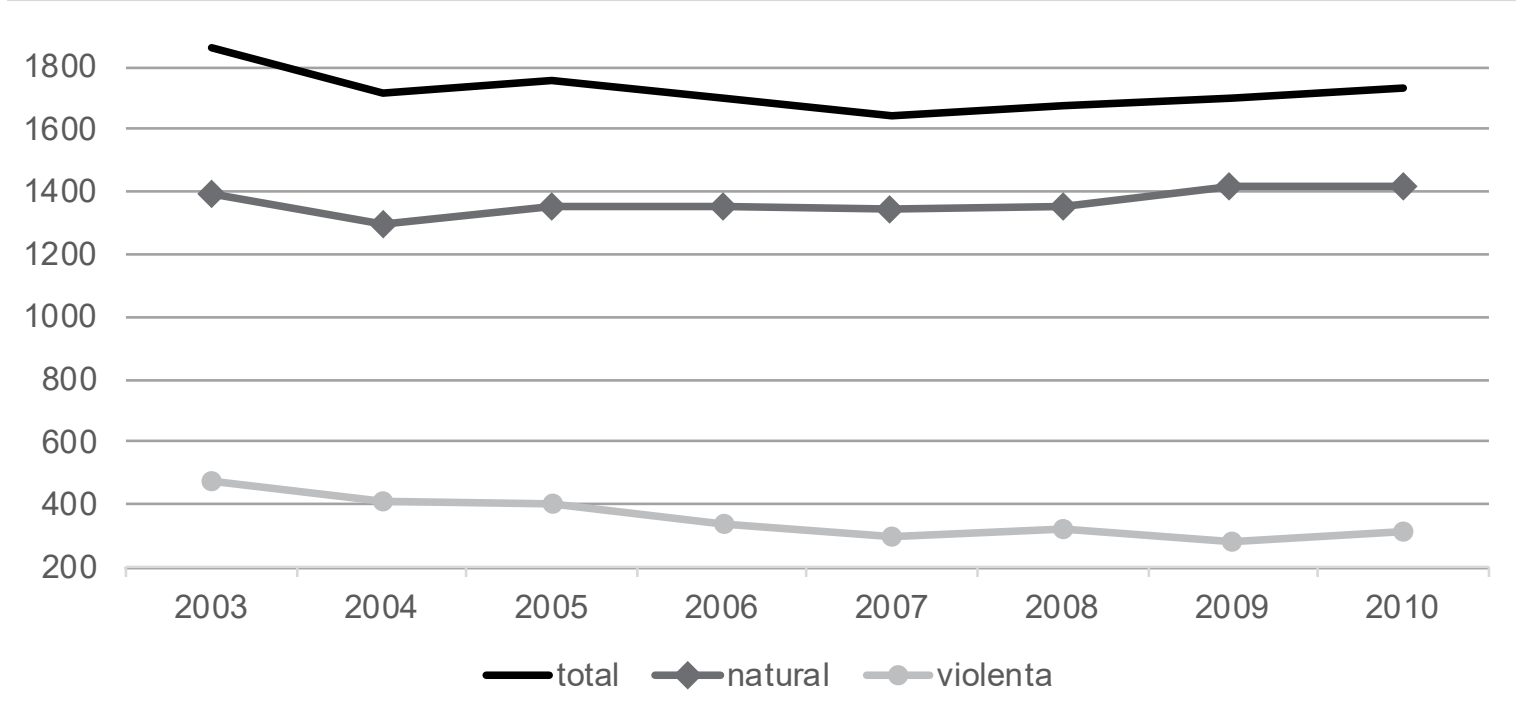

Fonte: IBGE

Essa época marca a valorilzação tanto dos cidadãos quanto do espaço público, quando foram reformadas diversas praças e parques, assim como oferecidas novas oportunidades e perspectivas aos munícipes, principalmente àqueles em estado de maior vulnerabilidade. É neste contexto que se deu a instalação do campus Diadema da Unifesp, em 2007, durante a gestão do ex-prefeito José de Filippi Júnior.

Hoje, um panorama geral do município de Diadema pode ser dado pelo estudo de Nigriello e Oliveira (2013), que caracterizou o território de Diadema como de "significativa densidade demográfica, presença de empregos, renda média per capita não muito baixa, alta presença de domicílios tipo cômodo, poucos domicílios sem redes de água e esgoto e sem coleta de lixo" (NIGRIELLO \& OLIVEIRA, 2913, p. 123) e uma das unidades territoriais da RMSP mais carentes em serviços públicos. 
Os gráficos das figuras 21, 22 e 23 anotam esses dados e demonstram que Diadema conta com segundo maior percentual de domicílios particulares permanentes ligados à rede geral de esgoto e ao abastecimento de água, assim como grande parte de suas residências ligadas à rede pública de eletricidade, com medidor (figura 24).

Figura 21 - Percentual de domicílios particulares ligados à rede regal de esgoto ou pluvial.

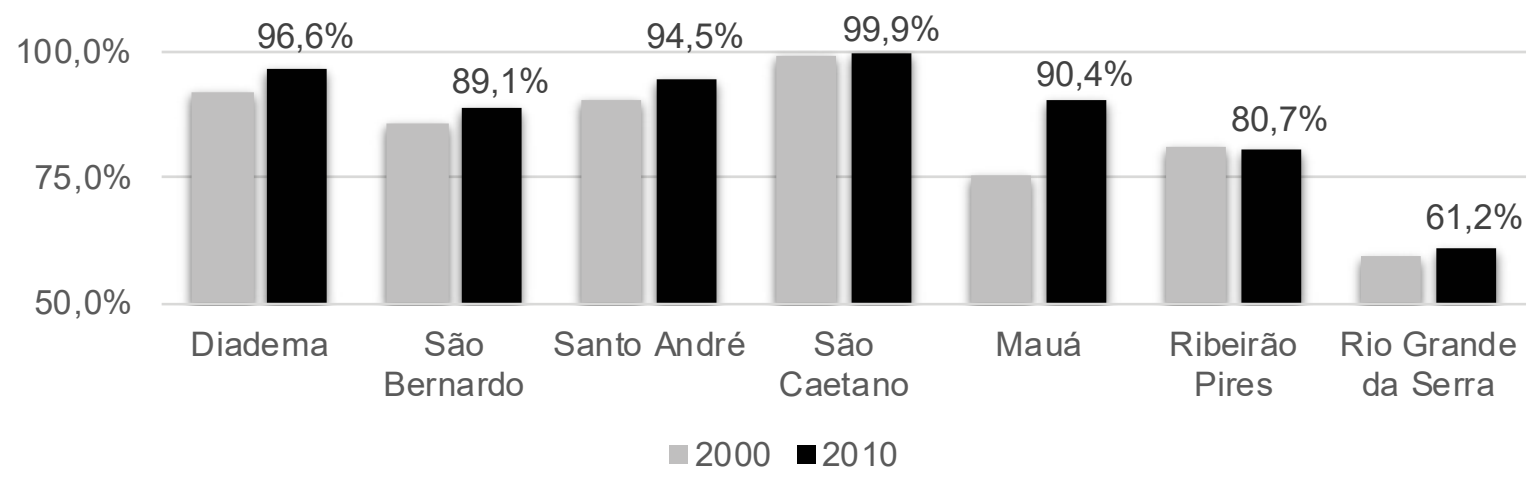

Fonte - IBGE. Elaboração própria.

Figura 22 - Percentual dos domicílios particulares permanentes não ligados à rede geral de esgoto ou pluvial em 2010.

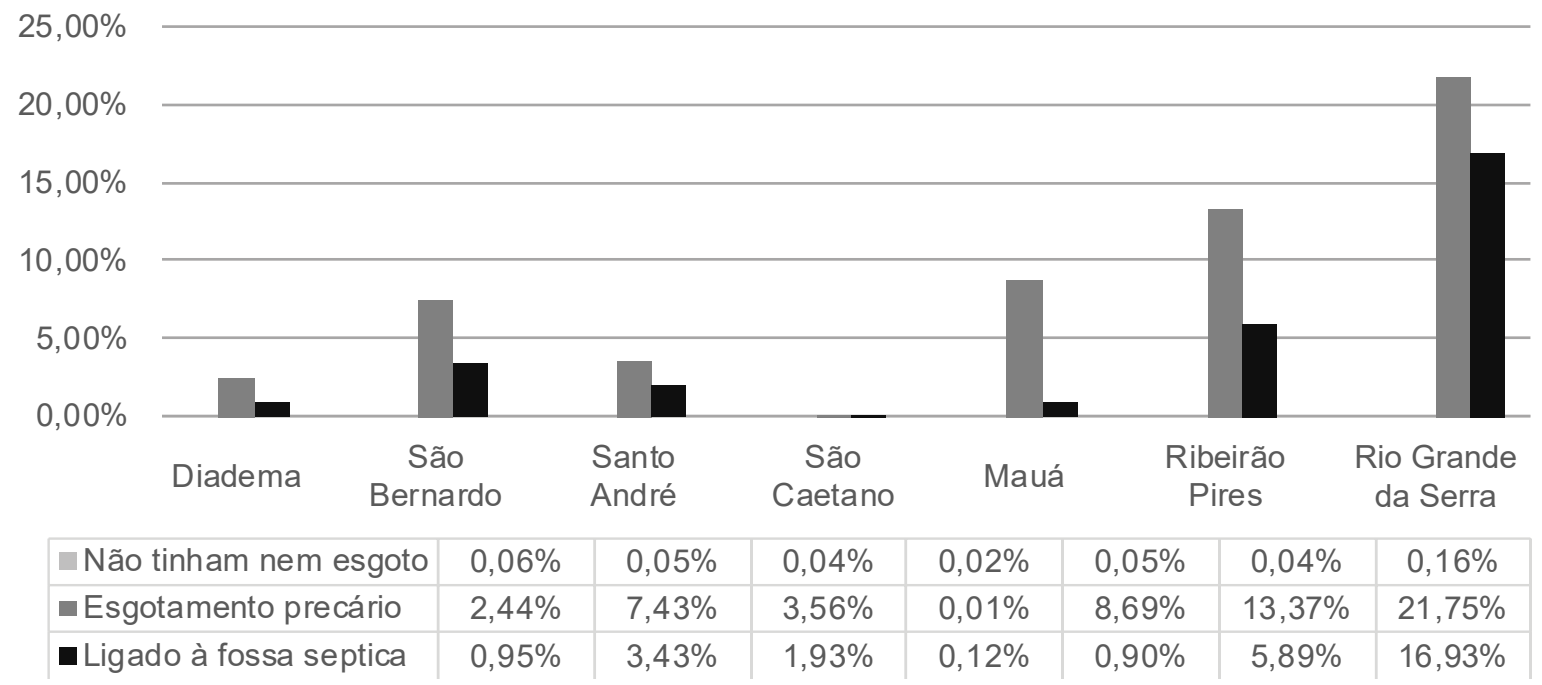

Fonte: IBGE. Elaboração própria.

Figura 23 - Percentual dos domicílios particulares permanentes abastecidos pela rede geral de água.

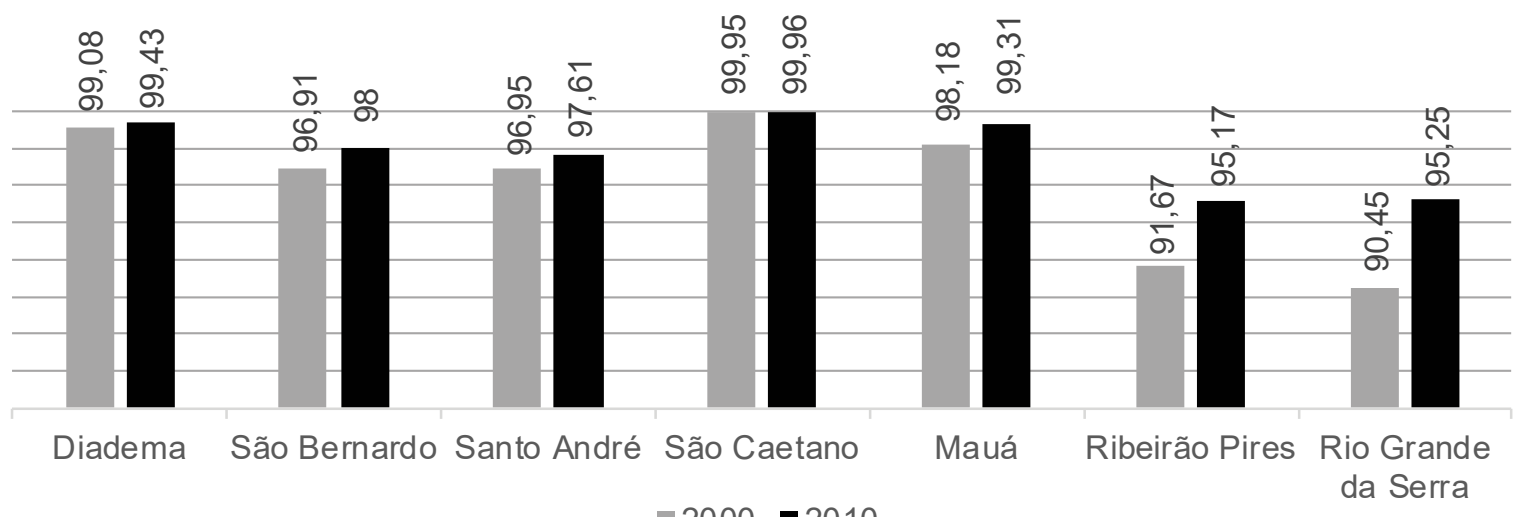

Fonte: IBGE. Elaboração própria. 
Figura 24 - Percentual dos domicílios particulares permanentes que tinham energia elétrica por companhia distribuidora em 2010 .

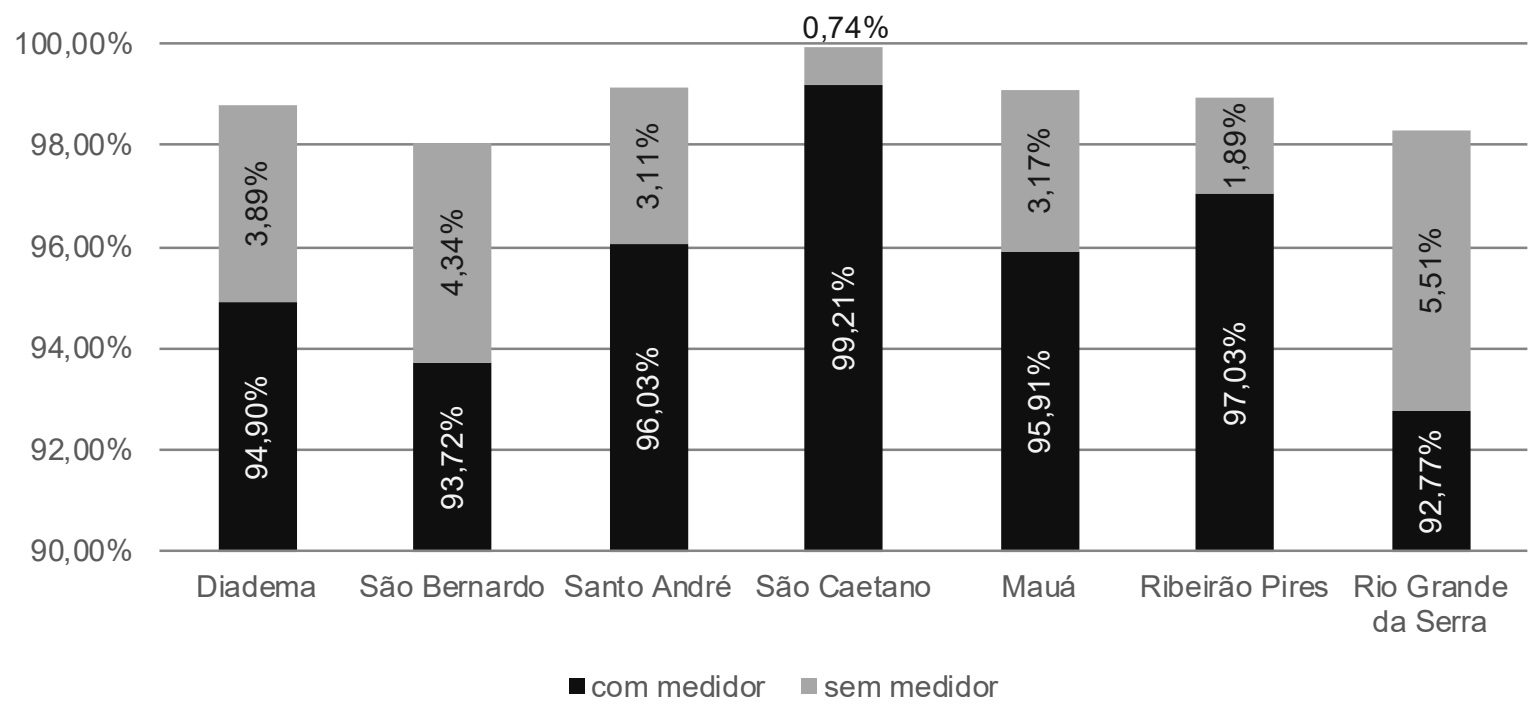

Fonte: IBGE. Elaboração própria.

Os programas de urbanização de favelas e o investimento em infraestrutura também fizeram com que, em 2010, 91,44\% dos domicílios estivessem em áreas com ordenamento regular (figura 25). Outros índices, como iluminação pública, pavimentação e identificação do logradouro passam dos $90 \%$, enquanto esgoto a céu aberto representa apenas $1,72 \%$ do total (figura 26).

Figura 25 - Número e percentual de domicílios permanentes em áreas urbanas com ordenamento regular em relação ao total de domicílios particulares permanentes em Diadema.

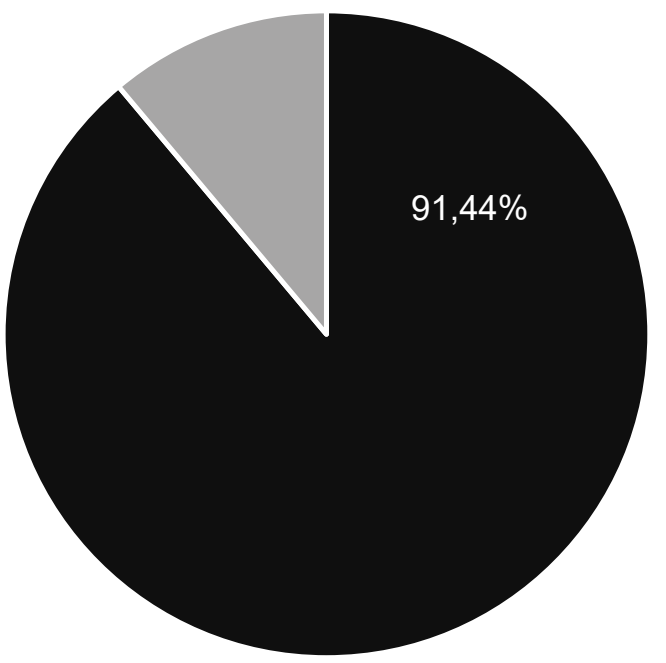

Domicílios particulares permanentes em áreas urbanas com ordenamento regular:

- Com ordenamento regular

- Sem ordenamento regular

Fonte: IBGE. Elaboração própria. 
Figura 26 - Percentual dos domicílios particulares permanentes em áreas urbanas com ordenamento regular de Diadema, por características do entorno em 2010.

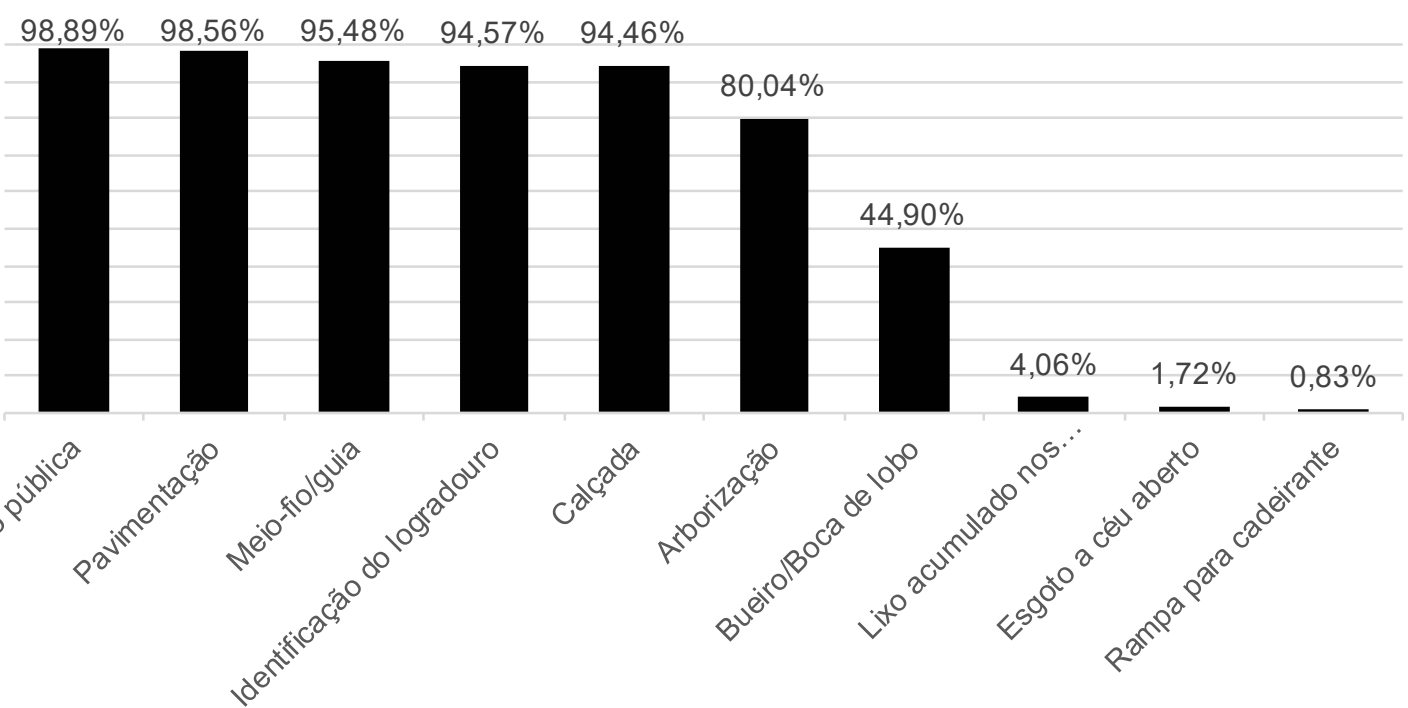

Foram excluídos desse percentual os domicílios particulares permanentes em áreas urbanas com ordenamento regular que não apresentaram declaração de características do entorno, as quais equivalem a 4.67\% desses domicílios (5.011 unidades). Fonte: IBGE. Elaboração própria.

Destaca-se que entre os bairros de Diadema a situação era de pouca desigualdade quanto à oferta de infraestrutura no final dos anos 90. Entretanto, o bairro do Eldorado, nos anos 2000, aparecia com índices abaixo da média do município. A prefeitura teve uma especial atenção com este bairro, o que culminou na implantação da primeira unidade do campus Diadema.

As figuras 27 e 28, representam a discrepância existente entre os bairros, e demonstram atenção dada ao Eldorado. Segundo o IBGE (2000 e 2010), neste bairro o percentual de domicílios ligados à rede de esgoto passou de meros 63\% em 2000 para 88,87\% em 2010. Da mesma forma, era o bairro com segunda menor porcentagem de domicílios sem abastecimento de água, com $95 \%$ em 2000 e passou a $97 \%$ em 2010 .

Em outro aspecto, Diadema chama a atenção pela elevada densidade demográfica, 12.536,99 hab $/ \mathrm{km}^{2}$ (IBGE, 2010), com pouquíssima verticalização, o que significa um padrão de pequenos lotes e edifícios, em sua quase totalidade notavelmente autoconstruídos. Isto corrobora com a ideia da cidade "COM-FUSA", desenvolvida por Abramo (2007): os processos de urbanização conduzem ao espraiamento da cidade, enquanto o alto custo da terra, os baixos salários e a restrição de lotes para ocupar conduzem a assentamentos altamente adensados, tanto em edificações quanto em habitantes. 
Figura 27 - Percentual dos domicílios particulares permanentes ligados à rede geral de esgoto ou pluvial nos bairros de Diadema.

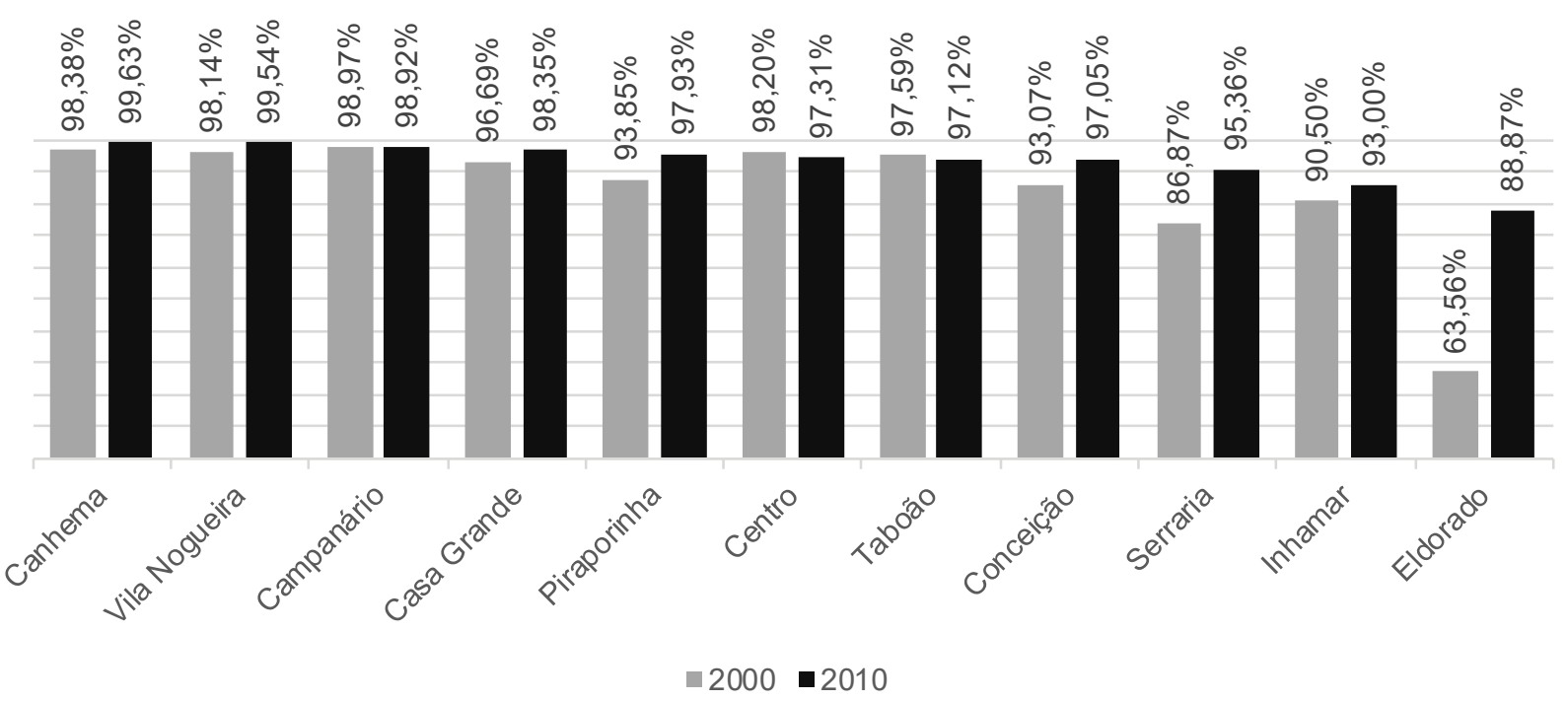

Fonte: IBGE. Elaboração própria.

Figura 28 - Percentual dos domicílios particulares permanentes abastecidos pela rede geral de água nos bairros de Diadema.

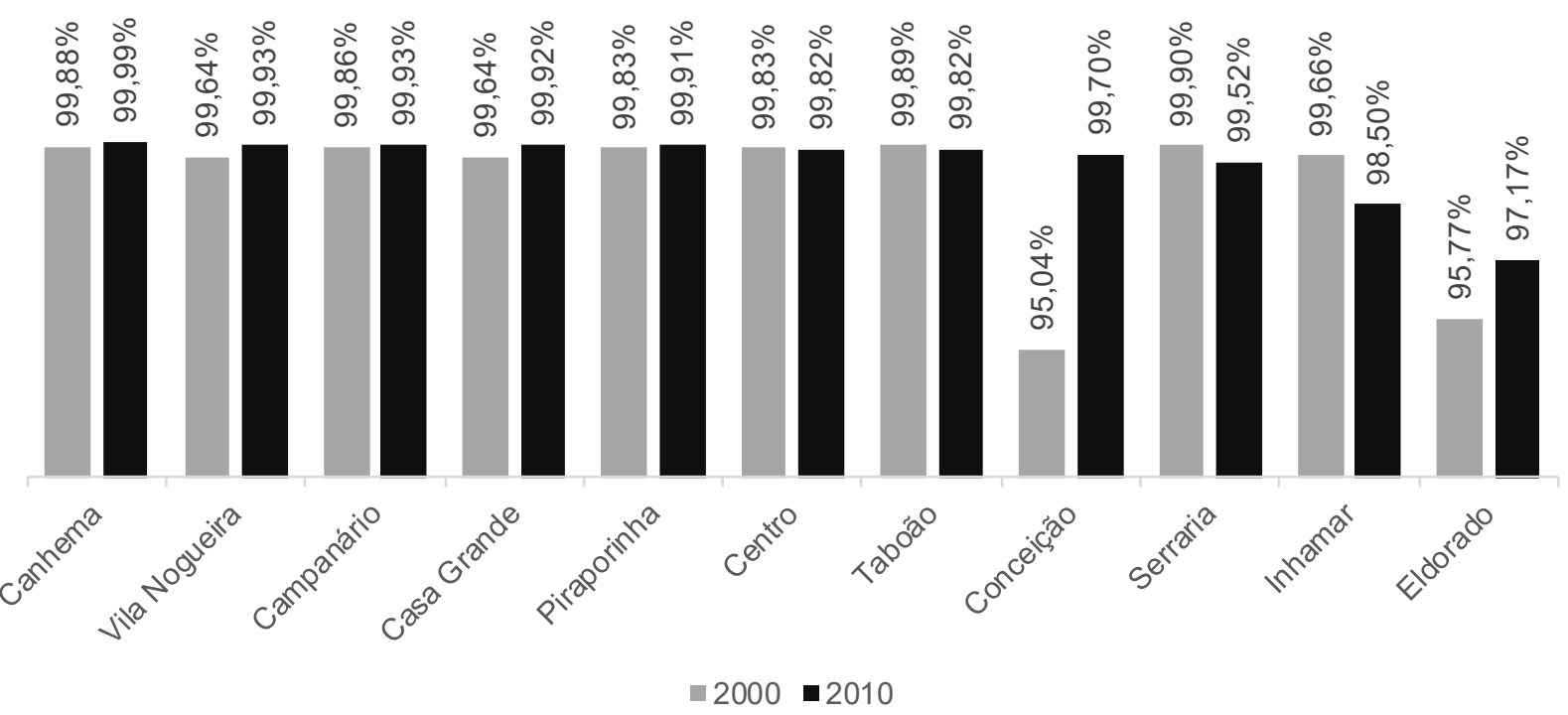

Fonte: IBGE. Elaboração própria.

Portanto, podemos destacar da formação do espaço urbano em Diadema o importante papel da indústria, sua forma de ocupação do território e área ocupada; a condição social de baixa qualificação e baixos salários; a autoconstrução e a alta densidade populacional.

É importante destacar que a formação do espaço urbano em Diadema é fruto desses elementos e, principalmente, de sua combinação, porque isso está intrinsecamente envolvido com a análise que se faz no presente estudo: o desenvolvimento urbano e regional é fruto de políti- 
cas urbanas e de tudo aquilo que lhe diga respeito diretamente, mas também da organização da sociedade e sua economia - seu modo de produção, ordem social, etc.

\section{2 - Transformações urbanas recentes em Diadema}

Durante as duas últimas décadas, o espaço urbano em Diadema vem passando por grandes mudanças. Por um lado, o mercado imobiliário avança com uma nova frente ao longo do eixo das principais avenidas, Keneddy, Eduardo Ramos Esquível e Piraporinha. Por outro lado, são notáveis as áreas industriais vazias.

O incremento da atividade do mercado imobiliário tem algumas características importantes. Em primeiro lugar uma alteração profunda do padrão de edificações, que passa da autoconstrução, pequenos lotes e edifícios baixos, para a construção de condomínios com conjuntos de torres isolados em grandes lotes e, em geral, fortificados.

A isto se combina uma elevação do padrão de consumo, que por sua vez demanda alterações na oferta de comércio e serviços. Isto é fruto não apenas de um crescimento da renda média dos trabalhadores de Diadema, mas, também, do deslocamento de população de outros municípios que buscam por alternativas de moradia mais barata.

Essa expansão do mercado imobiliário ocorre timidamente no setor de serviços, apesar do setor ter o maior valor adicionado bruto no PIB e com maior crescimento (figura 26). Algumas novas torres comerciais estão em construção ou foram recentemente construídas, assim como está em construção um novo shopping center, o segundo da cidade, no bairro da Serraria.

Em outro sentido, as áreas industriais esvaziadas têm se multiplicado. De acordo com José (2010) e Laurentino (2002), em uma primeira análise, pode-se imaginar que há um processo de desindustrialização em curso, como também ocorre em São Paulo. Devido à elevação do preço da terra, aos custos de aglomeração e às transformações nos processos produtivos, além de incentivos fiscais em outros municípios, muitas indústrias têm deixado a região metropolitana e rumado para outras áreas, com destaque ao interior do estado de São Paulo, mas também para todo o Brasil. Nas áreas onde esse processo já é acentuado existe uma profunda transformação do espaço, que vê antigas indústrias serem substituídas por condomínios residenciais e outros usos, ou tornando-se obsoletas e subutilizadas. 
Em Diadema, especificamente, ainda não se pode afirmar que este processo está avançando. Apesar de uma redução notável dos níveis de emprego na indústria, no valor adicionado bruto e na participação da indústria no PIB do município, não há clareza se isso é resultado de um processo de transformação produtiva ou de uma contração da economia a nível nacional.

Segundo o "Boletim do Observatório Econômico e do Trabalho de Diadema" (2017), os empregos formais na indústria recuaram cerca de $25 \%$ entre 2010 e 2015 , de 61.967 postos para 46.775. No mesmo período, os empregos nos setores de comércio e serviço mantiveram seus patamares, como se pode ver na figura 29.

Figura 29 - Evolução do emprego na indústria, comércio e serviços (2002 a abril de 2017).

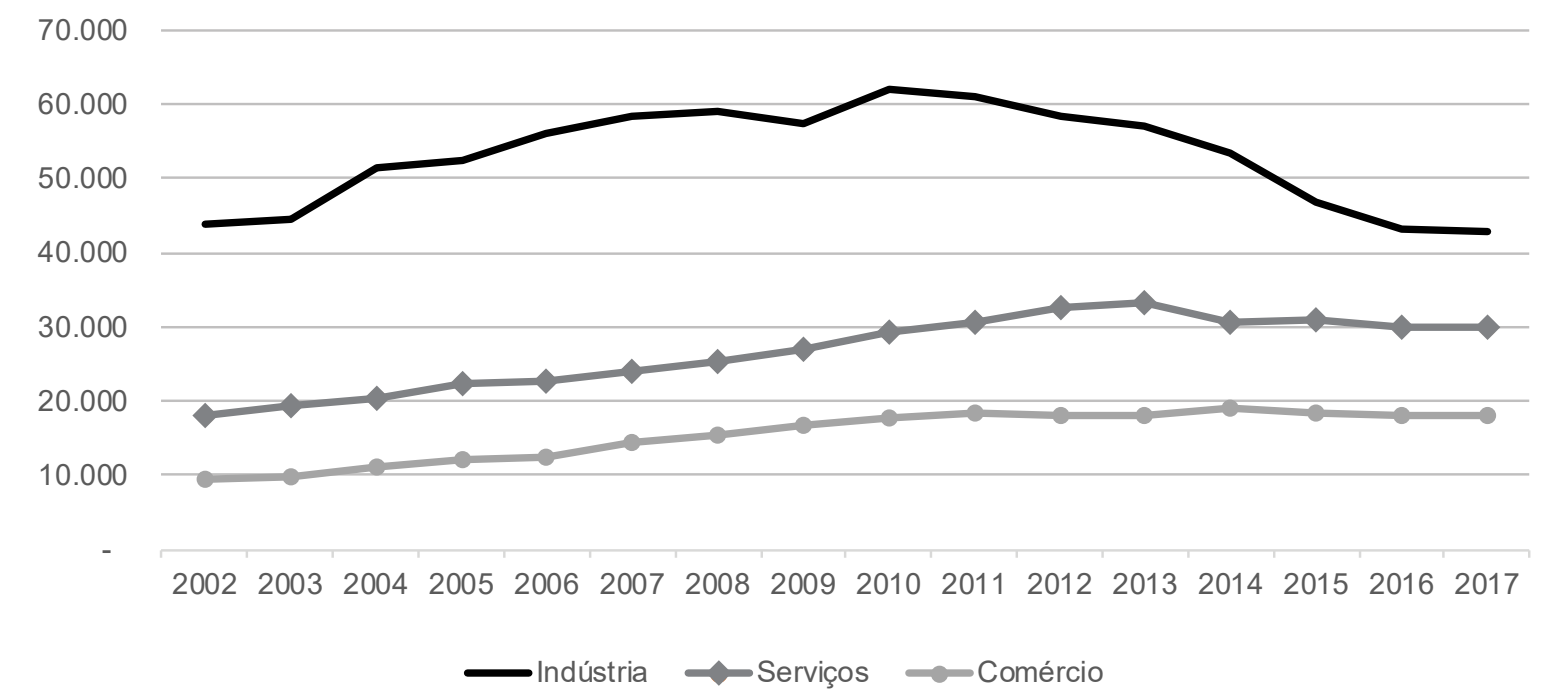

Fonte: MTE - RAIS. 2002 a 2015. CAGED, 2016 a abril de 2017.

Além da redução do emprego, o valor adicionado bruto pela indústria no PIB passou de R \$ 4,11 bilhões, em 2011, para R \$ 3,8 bilhões em 2015, retração de 8\%. Já a participação no PIB foi de $35 \%$ para $27 \%$ no mesmo período. Os gráficos das figuras 30 e 31 apresentam a série histórica desses dados. Outro índício é a queda das exportações, como ilustrado na figura 32, a seguir.

De qualquer forma, a indústria em Diadema tem enfrentado dificuldades, e algumas delas são relativas à estrutura do espaço urbano. Para o Entrevistado 3, algumas indústrias têm saído do município porque tiveram que reduzir sua atividade devido aos níveis de ruídos e proximidade de moradias. Ainda assim, considera que Diadema tenha vantagens, sobretudo com relação à facilidade de acesso e proximidade da capital. Em outros termos, há questões relativas ao valor de uso, tanto a favor quanto contra Diadema enquanto localização (VILLAÇA, 1998). 
Essa é a nossa visão: a questão da indústria em Diadema ainda é muito importante, muita gente procura pela localização, pela facilidade de acesso, pela proximidade da capital, então tem uma série de benefícios de estar em Diadema. Mas esse conflito entre a indústria e o morador gera uma dificuldade enorme de permanecer em Diadema. (Entrevista. Entrevistado 3. 16/05/2018).

Ainda que a desindustrialização possa não ser um processo em curso em Diadema, a preocupação que apontaram os Entrevistados 2 e 3 deixa claro que há uma desvantagem para a indústria se estabelecer em Diadema, comparado a outros municípios. Essa questão foi, inclusive, abordada no início da revisão do Plano Diretor de Diadema, em 2017, quando a própria Ciesp a encaminhou para discussão. A intenção é revisar a relação entre áreas habitacionais e industriais para que Diadema siga sendo atrativa para as indústrias, tanto para a instalação de novas quanto para a manutenção das existentes.

Figura 30 - Valor adicionado bruto por atividade econômica no PIB.

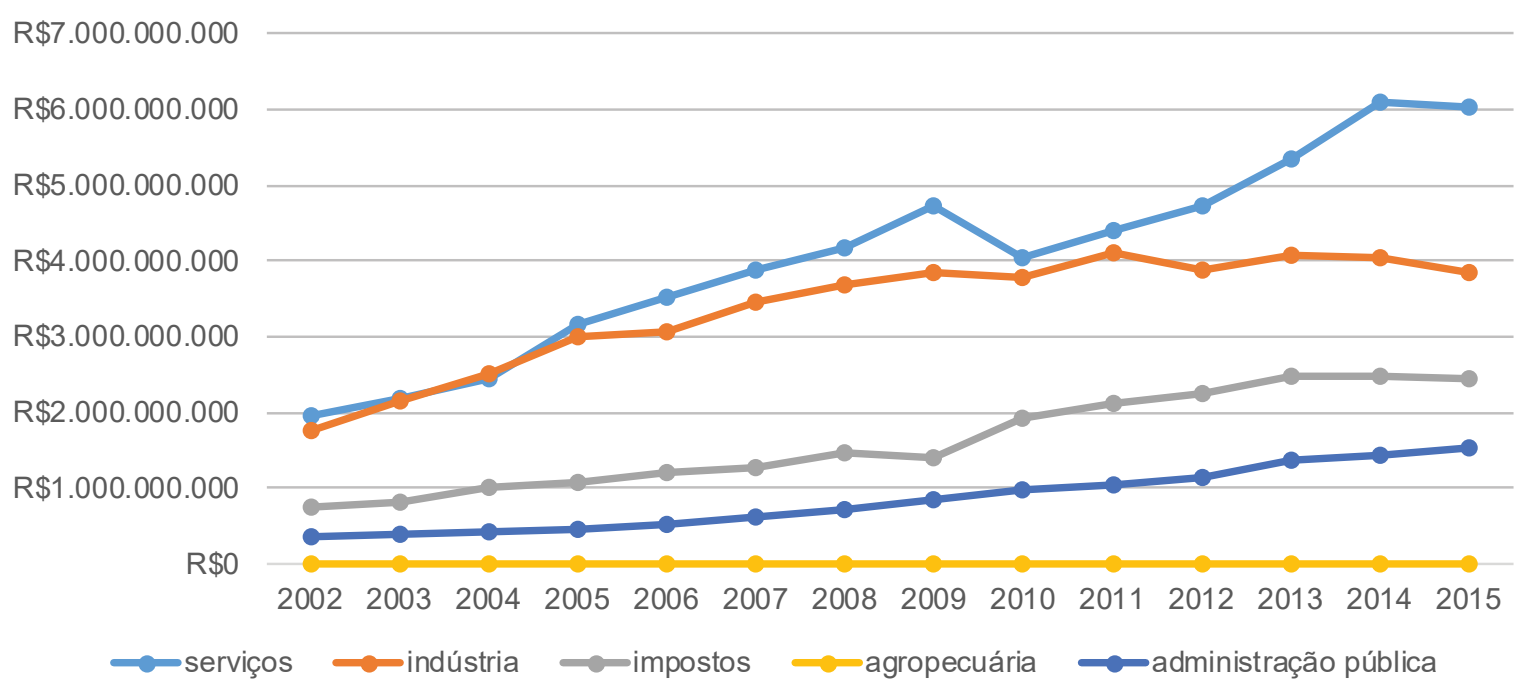

VAB a preços correntes. Fonte: IBGE

Figura 31 - Participação das atividades econômicas no PIB.

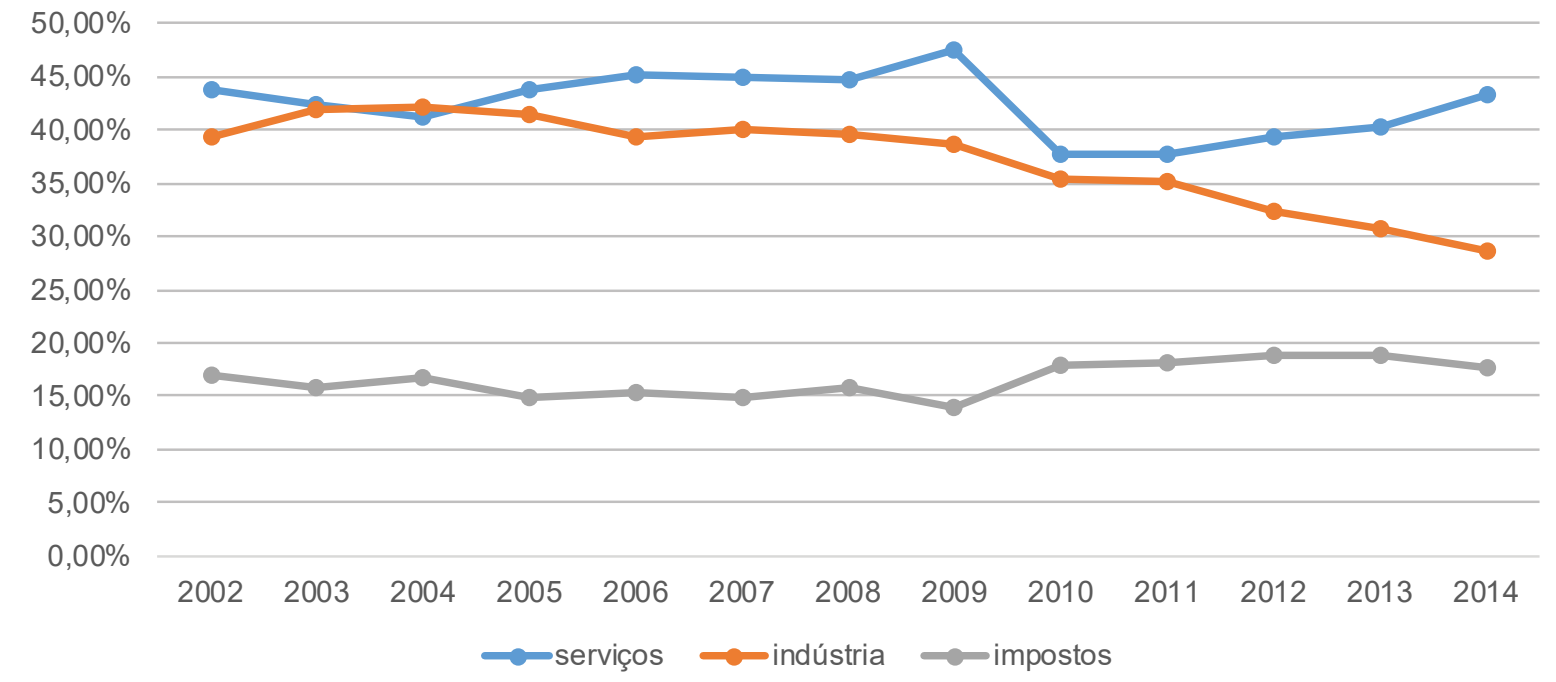

Fonte: IBGE. Elaboração própria. 
Figura 32 - Balança comercial de Diadema - 2000 a 2016.

$\mathrm{R} \$ 1.200 .000 .000$

$\mathrm{R} \$ 1.000 .000 .000$

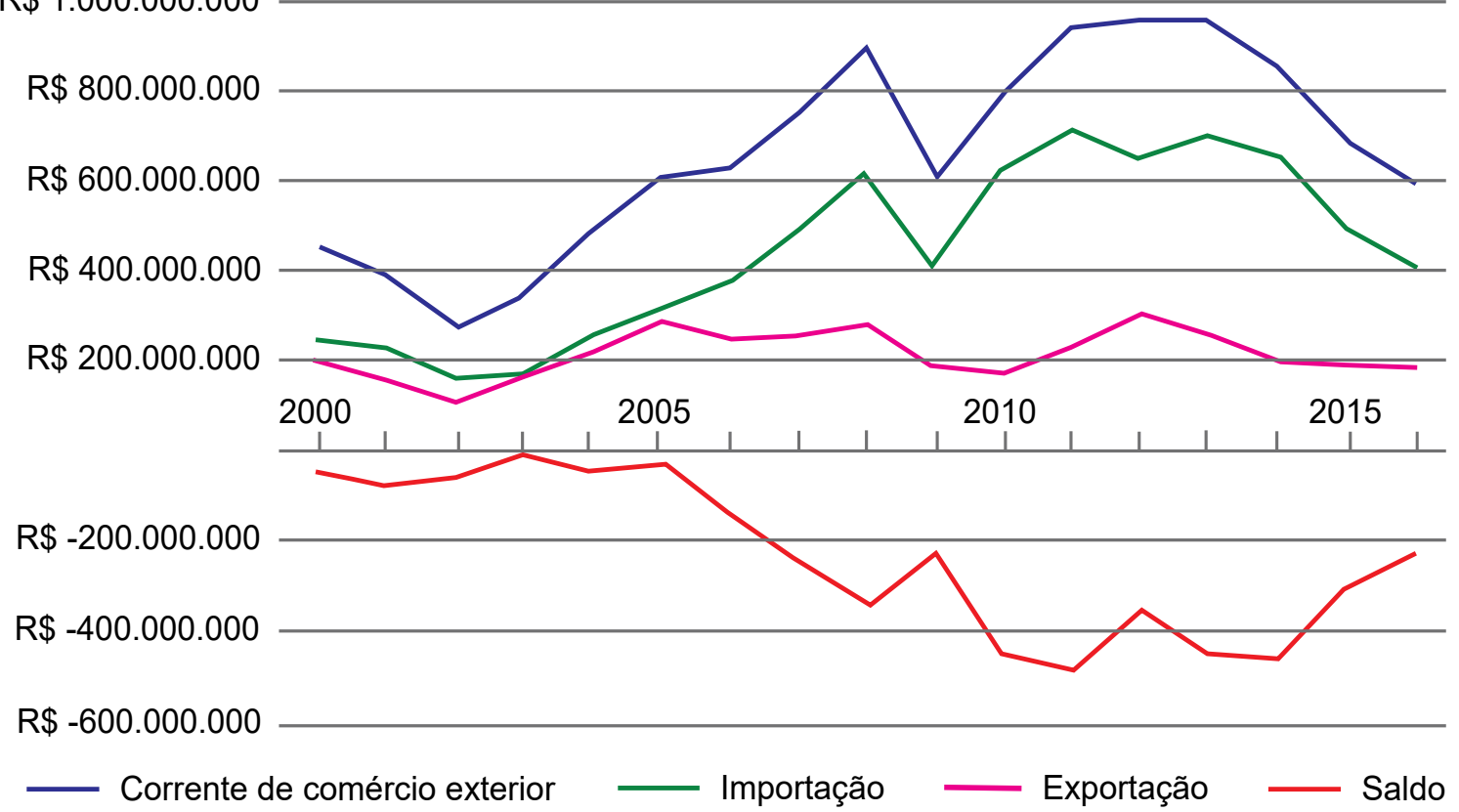

Fonte: MDIC - Secex

Uma outra possibilidade de futuro é que a indústria estabelecida enfrente cada vez mais a concorrência de outras áreas, mais novas e mais modernas e que, portanto, podem produzir de forma mais eficaz e eficiente. Entretanto, para o Entrevistado 3, a indústria de Diadema é competitiva e a questão tecnológica é um problema menor:

Mercado, lá fora, tem e é monstruoso para nós. A gente não participa praticamente de nada no mercado lá fora. As indústrias de Diadema têm plena condição de competir lá fora. Mas por conta de não conhecer direito o mercado, de ter um aperto financeiro e não conseguir viajar, por conta de algumas dificuldades em termos tecnológicos, mas eu diria isso num nível muito mais baixo, daria para competir, mas não estamos indo buscar. (Entrevista. Entrevistado 3. 16/05/2018).

Apesar de minimizar as "dificuldades tecnológicas", o que se tem visto ao redor do mundo é a aceleração das transformações na estrutura produtiva, fruto de altos investimentos em inovação e pesquisa. Furtado (1980) já advertia que a inovação é inerente ao o processo de desenvolvimento em qualquer modo de produção. Mas para o modo de produção capitalista isso tem um outro sentido: as inovações são indispensáveis na competição pelos mercados.

Entretanto, para o Entrevistado 3, a condição econômica do país não permite aos industriais ocuparem-se do incremento tecnológico aos seus negócios: "o que a gente vem percebendo aqui, é exatamente essa situação: os industriais estão tão focados dentro da empresa deles, em tentar gerir, tentar buscar novos mercados para poder sobreviver, que acabam não 
indo buscar essa tecnologia." (Entrevista. Entrevistado 3. 16/05/2018). Entretanto, a busca de novos mercados se resumiria ao próprio Brasil já que, como mencionado acima, não haveria condições para buscar mercados externos, apesar de existir, ser "monstruoso" e a indústria de Diadema ter condições de competir.

O mesmo ponto de vista foi expressado pelo Entrevistado 1. Para ele os industriais da região "têm negócios que estão com problemas. Cada vez mais com valor mais baixo agregado e eles estão lá tentando dar uma sobrevida para o negócio deles" (Entrevista. Entrevistado 1. 11/05/2018).

Apesar disso, acredita-se que a relação das indústrias de Diadema não se diferem do padrão nacional no que diz respeito ao recurso à inovação e ao desenvolvimento tecnológico, que são historicamente frágeis. Aurea e Galvão (1998) advertem para o fato de que não é de hoje que a indústria no Brasil, de forma geral, esteja afastada da pesquisa e da inovação:

"não se desconhece o fato de que a relação das empresas instaladas no país com a
variável tecnológica, no geral, sempre foi tênue, de pouca densidade (...) As empresas
pouco se dedicaram no país a esforços mais consistentes de capacitação tecnológi-
ca, utilizando em larga medida, o recurso às importações de tecnologia" (AUREA \&
GALVÃO, 1998, p. 21)

Mesmo quando o país esteve economicamente em situação favorável, como entre 2003 e 2010, a aproximação da indústria à pesquisa e inovação foi tímida. O documento "O desafio de posicionar o Brasil na rota do desenvolvimento"19 (2018), elaborado em conjunto pela FIESP e o Ciesp, aponta para um aumento significativo do investimento privado em pesquisa e inovação. ARBIX (2010) concorda que nos anos 2000 houve um crescimento do interesse e investimento privado em inovação, mas destaca que ainda é uma parte muito pequena das indústrias de capital nacional (1,7\%). Para o autor, além das condicionantes históricas, o debate sobre investimentos em pesquisa, desenvolvimento e inovação, embora remonte à década de 1960, só tomou corpo a partir de uma série de políticas públicas implementadas durante os governos Lula.

Por outro lado, o relatório "Research in Brazil" não houve elevação significativa da participação das indústrias nas publicações científicas nacionais. Ainda que tenha ocorrido um grande empenho do governo brasileiro para ampliar a pesquisa nacional, através do PACTI, as

19 Disponível em: <http://hotsite.fiesp.com.br/downloads/decomtec/20180928/PROJETO-AGENDA-WEB. pdf?pk_campaign $=5062392 \&$ pk_kwd=emkt $>$. Acesso em 09/01/2019. 
universidades públicas mantiveram-se como os mais importantes centros de pesquisa e sem uma expressiva colaboração das indústrias.

Segundo o relatório, $0,99 \%$ das publicações científicas feitas no país tem participação de indústrias (essa proporção é de 1,34\% no México, 2,75\% na Argentina e 3,52\% na França), sendo que apenas $0,4 \%$ do total é feito em colaboração com indústrias nacionais. Dentre os 0,99\% do total, $10 \%$ é realizado com a Petrobras, empresa com maior produção cientifica no país, seguida de empresas europeias e norte americanas, conforme a tabela 6 , abaixo.

Tabela 6 - Principais empresas que colaboraram com publicações científicas no Brasil de 2011 a 2016, por volume de publicações.

\begin{tabular}{|l|l|l|l|}
\hline Empresa & País & Publicações & Setor \\
\hline Petrobras S.A. & Brasil & 190 & Petróleo \\
\hline GlaxoSmithKline & Reino Unido & 108 & Farmacêutico \\
\hline Novartis & Suíça & 106 & Farmacêutico \\
\hline Roche Holding & Suíça & 81 & Farmacêutico \\
\hline Pfizer & Estado Unidos & 79 & Farmacêutico \\
\hline Merck \& Company & Estado Unidos & 67 & Farmacêutico \\
\hline Westat & Estado Unidos & 55 & Serviços profissionais \\
\hline Bayer AG & Alemanha & 54 & Farmacêutico \\
\hline Johnson \& Johnson & Estado Unidos & 54 & Farmacêutico \\
\hline AstraZeneca & Inglaterra & 53 & Farmacêutico \\
\hline Sanofi-Aventis & França & 51 & Farmacêutico \\
\hline IBM & Estado Unidos & 49 & Computação \\
\hline Eli Lilly \& Company & Estado Unidos & 48 & Farmacêutico \\
\hline Bristol Myers Squibb & Estado Unidos & 48 & Farmacêutico \\
\hline Amgen & Estado Unidos & 38 & Biotecnologia \\
\hline Johnson \& Johnson USA & Estado Unidos & 33 & Farmacêutico \\
\hline Genentech & Estado Unidos & 33 & Farmacêutico \\
\hline AT\&T & Estado Unidos & 32 & Telecomunicaçes \\
\hline Hewlett-Packard & Estado Unidos & 30 & Softwares \\
\hline $\begin{array}{l}\text { Bayer Helthcare } \\
\text { Pharmaceuticals }\end{array}$ & Alemanha & 28 & Farmacêutico \\
\hline
\end{tabular}

Fonte: Research in Brasil - Clarivate Analytics. Elaboração própria. Tradução livre.

Os outros $99,1 \%$ do total de publicações são realizados por universidades, públicas em sua maioria, sendo que a USP se incumbe de $20 \%$ do total. A Unifesp, como um todo, representa $3,9 \%$ do total e tem uma das mais altas taxas de colaboração de indústrias $(1,24 \%$ de suas publicações), atrás apenas das universidades Federal do Rio de Janeiro (UFRJ) e Federal Fluminense (UFF), que têm amplo apoio da Petrobrás. Abaixo, apresenta-se a tabela 7, com as universidades brasileiras com maior quantidade de publicações no período 2011-2016.

Nota-se que esse fator não é acaso, senão resultado de um modelo de desenvolvimento que perdurou por todo o século XX no Brasil: a transferência de tecnologia - importar tecnolo- 
gia dos países centrais, de acordo com a nossa posição na divisão internacional do trabalho, de acordo com Aurea e Galvão (1998).

Tabela 7 - Universidades brasileiras com maiores volumes de publicações científicas entre 2011 e 2016.

\begin{tabular}{|l|c|c|}
\hline Universidade & $\begin{array}{c}\text { Documentos } \\
\text { publicados }\end{array}$ & $\begin{array}{c}\text { \% de publicações } \\
\text { com colaboração } \\
\text { da indústria }\end{array}$ \\
\hline Universidade de São Paulo & 54.108 & 0,83 \\
\hline Universidade Estadual Paulista & 20.023 & 0,30 \\
\hline Universidade Estadual de Campinas & 17.279 & 1,11 \\
\hline Universidade Federal do Rio de Janeiro & 16.203 & 1,85 \\
\hline Universidade Federal do Rio Grande do Sul & 14.511 & 0,98 \\
\hline Universidade Federal de Minas Gerais & 13.294 & 0,9 \\
\hline Universidade Federal de São Paulo & 10.667 & 1,24 \\
\hline Universidade Federal do Paraná & 8.233 & 0,84 \\
\hline Universidade Federal de Santa Catarina & 7.908 & 1,09 \\
\hline Universidade do Estado do Rio de Janeiro & 6.433 & 1,04 \\
\hline Universidade Federal de Pernambuco & 6.420 & 0,46 \\
\hline Universidade Federal de Viçosa & 6.373 & 0,60 \\
\hline Universidade de Brasília & 6.218 & 0,77 \\
\hline Universidade Federal de São Carlos & 5.794 & 0,62 \\
\hline Universidade Federal de Santa Maria & 5.750 & 0,45 \\
\hline Universidade Federal do Ceará & 5.621 & 0,66 \\
\hline Universidade Federal Fluminense & 5.441 & 1,43 \\
\hline Universidade Federal de Goias & 4.217 & 0,88 \\
\hline Universidade Federal da Bahia & 4.198 & 0,69 \\
\hline Universidade Estadual de Maringá & 4.067 & 0,59 \\
\hline
\end{tabular}

Fonte: Research in Brasil - Clarivate Analytics.

A transferência de tecnologia é uma das formas de acesso a inovações. Segundo Aurea e Galvão (1998) há outras duas. Uma é a importação de bens e serviços prontos, ou seja, não há mudança nas estruturas produtiva, mas sim no consumo. Outra é a pesquisa, que gera as inovações e que produz as suas próprias modificações na estrutura produtiva - onde predomina essa forma de acesso, são profundos os vínculos entre a base técnico-científica e produtiva, entre empresas e centros de pesquisas e universidades.

Para os autores, os países centrais têm capacidade de recorrer muito mais à produção de inovações internamente do que às importações, enquanto ocorre o inverso nos países periféricos, de acordo com seu grau de desenvolvimento econômico e técnico. Assim, a possibilidade de alinhar empresas e centros de pesquisa regionalmente significaria romper um padrão histórico de industrialização. 
Essa importância da pesquisa, da inovação e do desenvolvimento tecnológico foi reconhecida pelos membros entrevistados do Ciesp, mas colocaram a questão econômica nacional acima disso, como um fator inibidor e até impeditivo para que as empresas fizessem investimentos nesse sentido. Além disso, também compreenderam que os centros de pesquisa e as universidades têm papel importantíssimo.

Para o Entrevistado 2 a indústria de Diadema "necessita de tecnologia e conhecimento. Então a universidade nesse contexto tem um papel importante de fazer essa conexão da pequena indústria à inovação, ao desenvolvimento e à pesquisa" (Entrevista. Entrevistado 2. 16/05/2018). Para ele, a relação da indústria com os centros de pesquisa, de forma geral, é de suma importância para a competição internacional:

Hoje nós estamos competindo com o mundo e a indústria para poder se tornar tecnologicamente adequada a isso, com esse perfil de pequena... esse relacionamento com os órgãos de pesquisa (e ai a Unifesp, o Senai, o IPT) é de suma importância para o desenvolvimento do negócio. (Entrevista. Entrevistado 2. 16/05/2018).

Ainda assim, ele mesmo reconhece que as indústrias da região não têm recorrido muito às universidades devido, sobretudo, a divergências no "tempo de resposta":

O que eu posso te colocar é que o problema, hoje, é o tempo de resposta. O tempo da universidade é diferente do tempo da necessidade de uma indústria de atender o mercado. Olhando o setor de cosméticos, que é um setor onde a inovação é pujante, diária, é um setor que lança novos produtos, busca novas formas de atender o consumidor final quase que diariamente, a velocidade de resposta tem que ser adequada a esse tempo. Acho que o gargalo entre universidade e indústria é o tempo de resposta para essas demandas que surgem na indústria (Entrevista. Entrevistado 2. 16/05/2018).

O professor Ricardo Galdino, pelas suas interações com as indústrias da região, compartilha dessa percepção e a apresenta da seguinte forma:

Qual o grande problema dessa interação dessa indústria com a universidade? O tempo. O tempo da indústria é muito reduzido em relação ao tempo da universidade. A universidade está sempre querendo fazer um trabalho que é de 2 anos, com o mestrado, ou de 4 anos [doutorado]. A indústria quer fazer um trabalho de meia hora. Ele quer chegar e quer sair com a resposta. Porque aquela resposta para ele é dinheiro e o nosso resultado, aqui na universidade, não vem em forma de dinheiro. Ele vem em forma e alunos bem qualificados que tenham condições de ingressar no mercado de trabalho de maneira satisfatória. Então, esse que é o nosso resultado. Então é muito diferente. E isso gera uma diferença no tempo de resposta. Essa diferença no tempo de resposta às vezes gera um desajuste entre a participação da indústria na vida acadêmica e os próprios pesquisadores (Entrevista. Prof. Dr. Ricardo Galdino. 16/05/2018).

Ele acrescenta que muitas vezes as indústrias encaminham problemas específicos da produção e, por isso, a exigência de prazos curtos para as respostas. Por isso, entende-se o caráter das demandas das indústrias como individualistas e de curto prazo. 
É importante considerar que as universidades têm muito mais importância na perspectiva de médio e longo prazo do que a curto. Aurea e Galvão explicam que "cada vez mais a inovação é fruto de um trabalho especializado, realizado por equipes de pesquisadores e tecnólogos, com horizonte de longo prazo" (AUREA \& GALVÃO, 1998, p. 8).

Para o Entrevistado 1, industrial de Diadema, essa urgência das indústrias da região do $\mathrm{ABC}$ reside no seu caráter - sua opinião vai ao encontro daquela defendida por Aurea e Galvão (1998). Para ele há uma distinção entre indústrias e fábricas: enquanto aquelas são responsáveis pela inovação e pesquisa, estas funcionam dia e noite para produzir o que já foi criado. Indústrias estariam, então, conectadas ao futuro, à criação de algo novo, enquanto as fábricas ao passado, ao que já foi inventado e só precisa ser reproduzido e vendido. De acordo com ele, a maior parte das indústrias de Diadema são, na verdade, fábricas ${ }^{20}$, por isso teriam pouco interesse em parcerias com a universidade:

O que a fábrica vai fazer com a universidade lá dentro? Pensa! O que a fábrica vai fazer com a universidade dentro dela? Nada! (...) Ela está olhando para o produto! Ela não está desenvolvendo um produto novo. Ela nem pode, ela tem que entregar essa peça! Então, a universidade não vai fazer nada lá dentro da fábrica . (Entrevista. Entrevistado 1. 11/05/2018)

Portanto, unir universidade e indústria é uma questão mais profunda, de alterar o perfil da indústria da região. Nos termos do Entrevistado 1, é preciso mudar a proporção entre indústrias e fábricas. Nas palavras dele, é preciso que "a universidade me ajude a desenvolver Indústrias!”. (Entrevista. Entrevistado 1. 11/05/2018). Para CARLEIAL e CRUZ (2009), que elaboraram estratégias para o desenvolvimento regional, é indispensável uma transformação produtiva profunda:

nenhuma dessas propostas, entretanto, quer individualmente, quer em seu conjunto, poderá ser implementada unicamente pela ação dos diferentes mercados. Essencialmente, elas exigem uma intervenção consensual, planejada e decisiva, visando à mudança das estruturas produtivas, especialmente nas regiões Norte e Nordeste brasileiros. O foco das estratégias é, então, atingir as estruturas produtivas e, em consequência, o lugar de cada uma dessas regiões na divisão inter-regional do trabalho no Brasil. (CARLEIAL e CRUZ, 2009, p. 17).

De outra forma, é preciso criar condições para que surjam empresas que invistam em criar novos processos e novos produtos, como fundamento. Isso não se fará sem uma mudança econômica a nível nacional, da qual as universidades fariam parte e teriam papel central.

20 Como comentado anteriormente, apesar da distinção apresentada pelo Entrevistado 1 entre fábricas e indústrias, optou-se por permanecer com o uso da palavra indústria para ambos os casos afim de evitar confusões. 
Desta forma, pode-se vislumbrar que Diadema poderá enfrentar a desindustrialização devido à perda de vantagens comparativas e a uma fortíssima concorrência impulsionada pela inovação, sobretudo de seu setor mais tradicional, a metalurgia, devido à adoção de impressoras 3D de metais, o que transformará radicalmente a produção e os produtos.

Cabe destacar, por fim, que devido à área ocupada e à importância econômica das indústrias de Diadema para a economia municipal, haverá, evidentemente, importantes rebatimentos para o espaço urbano, tanto pelo enfrentamento da concorrência quanto pela perda de competitividade. Nesse sentido, apesar de parte dos trabalhos de pesquisa das universidades, e sobretudo do campus Diadema, serem voltados diretamente para a produção industrial, o espaço urbano e regional também podem ser afetados pelos seus trabalhos de pesquisa.

\section{3 - Caracterização social e educacional de Diadema}

Até aqui, percorreu-se o desenvolvimento urbano em Diadema e destacaram-se algumas condicionantes e características mais importantes do território, da economia e da sociedade. A seguir, pretende-se destacar dados sobre o campo da educação, porque eles serão importantes para se reforçar alguns aspectos da formação do espaço urbano, da condição social do município, assim como para facilitar a compreensão de parte da colaboração que o campus Diadema traz para o município e a região.

Uma das características mais marcantes do tecido social de Diadema é sua fragilidade. Como apontou-se, o espaço urbano formou-se baseado na industrialização de baixos salários e escolaridade, assim como capacitação técnica, que resultou em um predomínio de habitações autoconstruídas, grande parte irregular e precária.

Entretanto, as décadas de 1980, 1990 e, sobretudo, 2000, foram marcadas por políticas

públicas que procuraram reverter o quadro que se havia formado. Como efeito, o IDHM passou de 0,528, em 1991 para 0,757, em 2010 (PNUD), sendo que a educação foi o componente que mais contribuiu para este aumento, como se pode ver na figura 33, devido à ampliação do acesso ao ensino fundamental, sobretudo.

Em 2010, 97,45\% das crianças com entre 6 e 10 anos estava matriculada na escola, e 96,13\% na faixa etária entre 11 a 14 anos (figura 34). Destaca-se que não há contribuições do 
campus Diadema nesses dados porque foi criado apenas 3 anos antes do levantamento dos dados.

Figura 33 - Composição do IDHM de Diadema por Censo. 1991 a 2010.

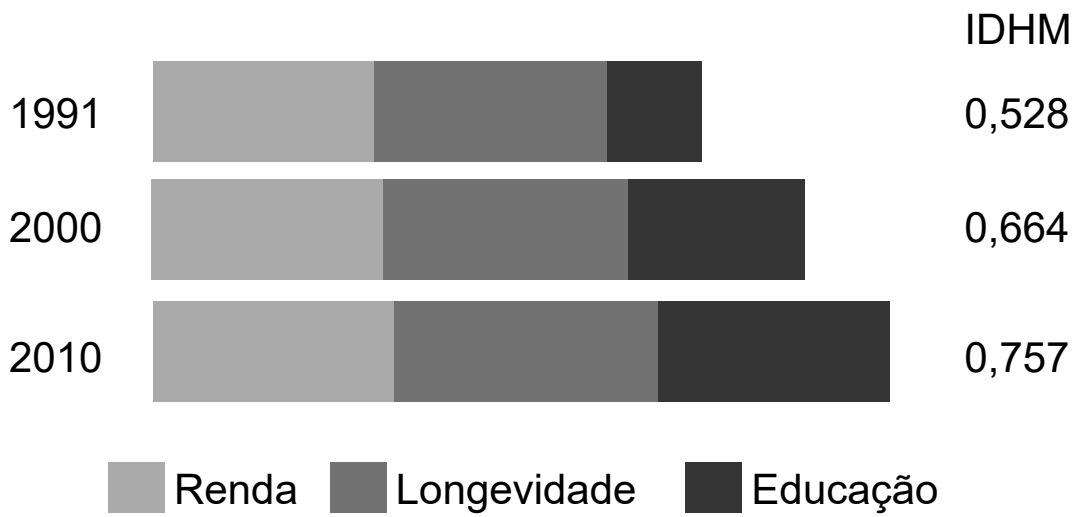

Fonte: IBGE. Elaboração Própria.

Figura 34 - População de crianças e adolescentes de Diadema que frequentava escola ou creche e percentual em relação à faixa etária, em 2010.

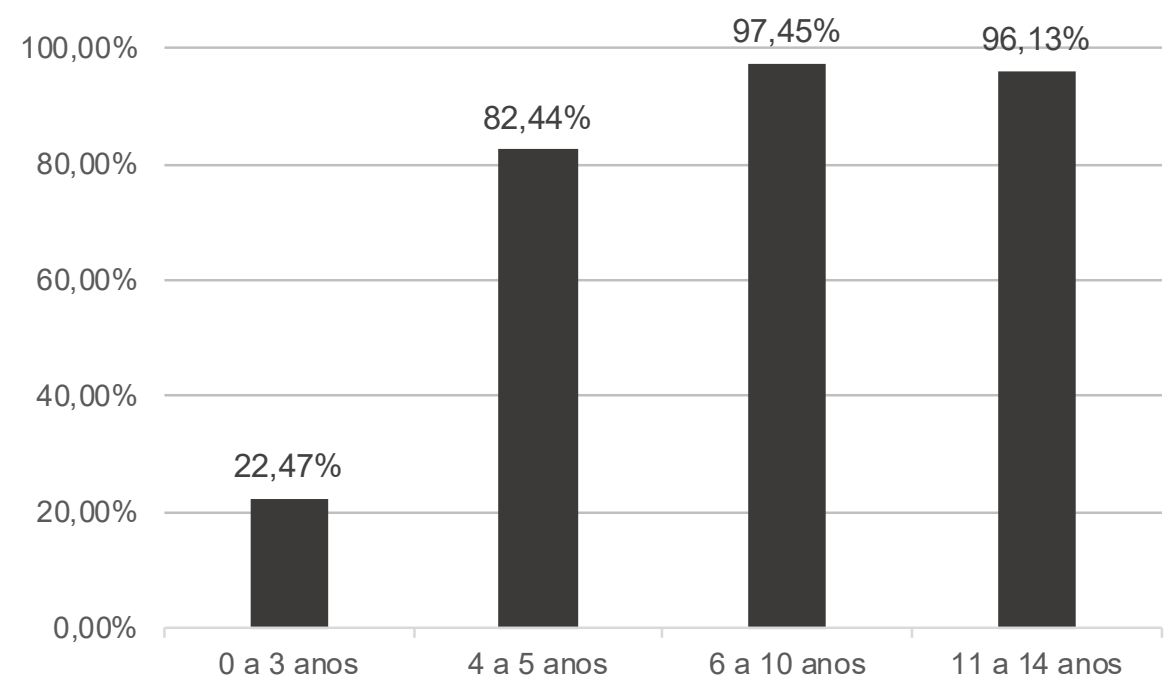

Fonte: IBGE. Elaboração Própria.

Os dados a seguir mostram que a população que nunca frequentou a escola, não alfabetizada e sem ensino fundamental completo, reduziram-se drasticamente na comparação entre gerações. A população que nunca frequentou a escola concentra-se acima dos 40 anos, representa $2,38 \%$ do total de habitantes (29\% daqueles entre 40 e 59 anos e $35 \%$ daqueles com mais de 60 anos); entre 6 e 17 anos são apenas $0,22 \%$ do total da população (2,8\% daqueles com 6 a 10 anos, $1,6 \%$ daqueles com 11 a 14 anos e 1,4\% daqueles com 15 a 17 anos, conforme figura 35 ). No total, $8 \%$ da população de Diadema nunca frequentou a escola ou creche, é o maior índice do Grande ABC (figura 36). 
Figura 35 - Percentual da população com quatro ou mais anos que nunca frequentou a escola ou creche, por faixa etária, 2010.

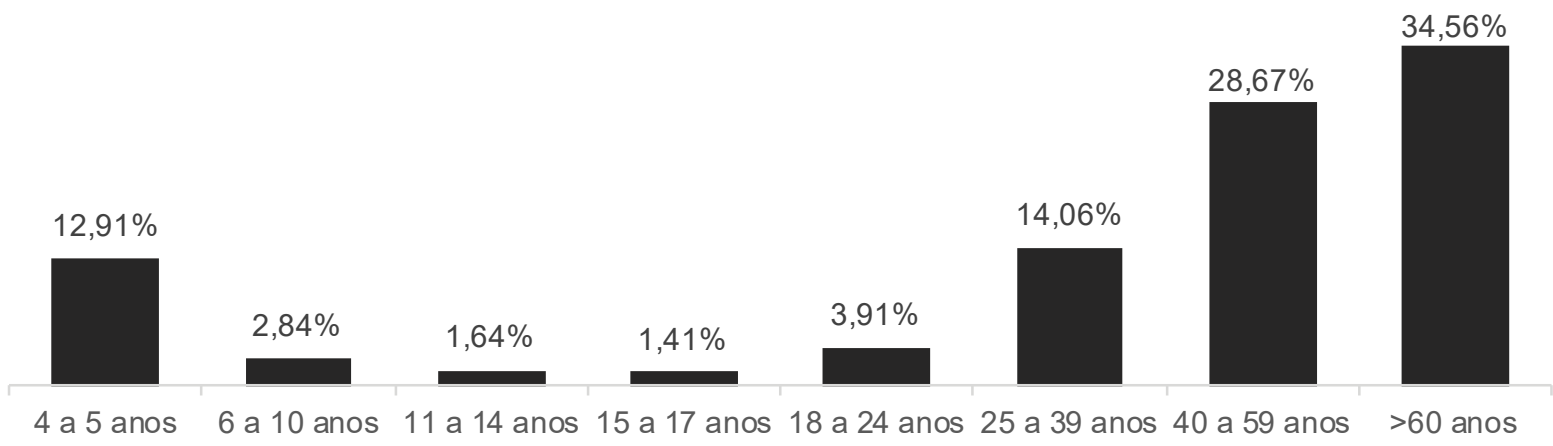

Fonte: IBGE. Elaboração própria.

Figura 36 - Percentual da população por frequência à escolha ou creche em 2010.

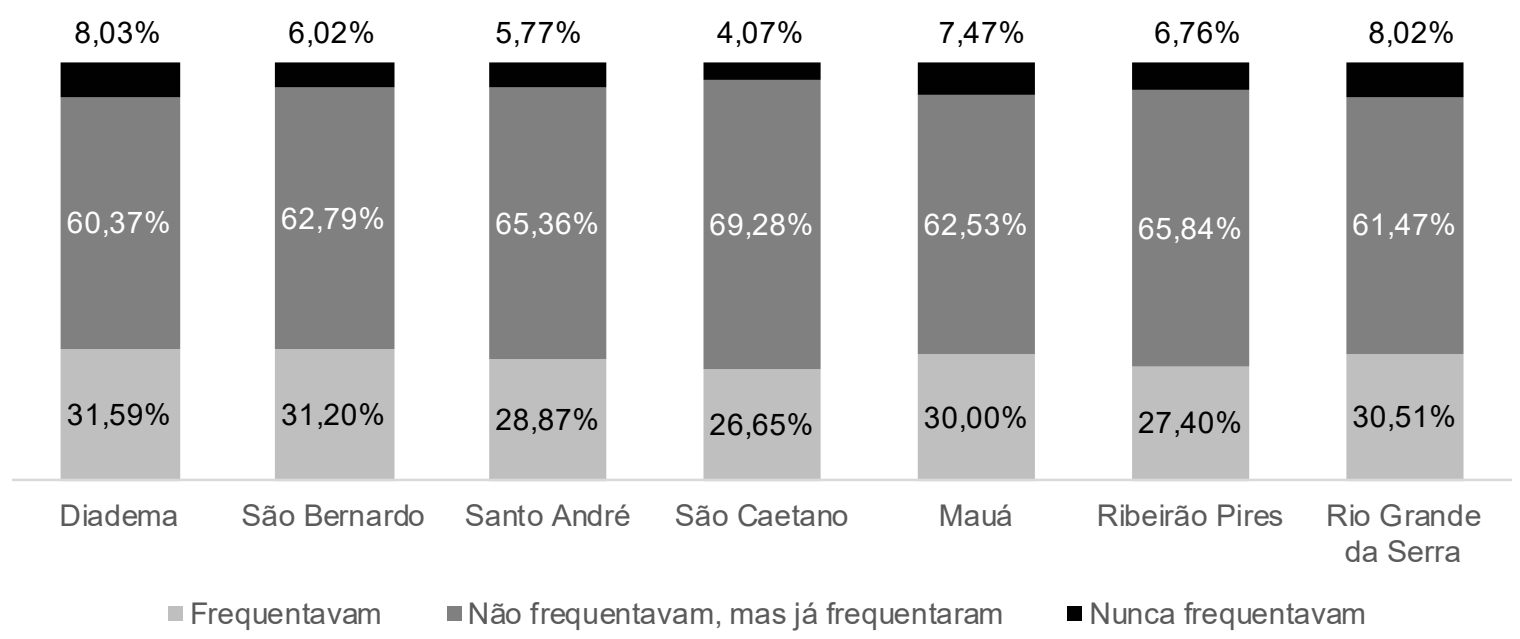

Fonte: IBGE. Elaboração própria.

Considerando que a industrialização aconteceu mais intensamente na década de 1970, em São Bernardo do Campo, e 1980 em Diadema, é justamente parte da população acima de 40 anos que foi trabalhar nas indústrias recém implantadas, o que corrobora com o argumento anterior de que a formação do espaço urbano em Diadema aconteceu baseado na industrialização de baixos salários e escolaridade.

Essa observação é complementada com os dados de ensino fundamental incompleto. $17,59 \%$ da população não completou o ensino fundamental e tem mais de 40 anos; esse número cai para $6,91 \%$, com entre 25 e 39 anos; e vai a 3,54\%, com 15 a 24 anos, conforme figura 37.

Considerando-se aqueles com mais de dez anos que não foram alfabetizados, o grupo com 40 ou mais anos concentra $2,72 \%$ da população, $0,52 \%$ com aqueles entre 20 e 39 anos e $0,2 \%$ a porcentagem daqueles entre 10 e 19 anos, como demonstrado na figura 38 . Somados 
todos os grupos, hoje 4,1\% da população com mais de 10 anos de idade, que não foi alfabetizada, frente aos 6,22 de 2000, ou seja, é a segunda maior taxa de analfabetismo do grande ABC, vide figura 39.

Figura 37 - População de Diadema com 15 anos ou mais sem instrução ou com fundamental incompleto, por faixa etária, 2010.

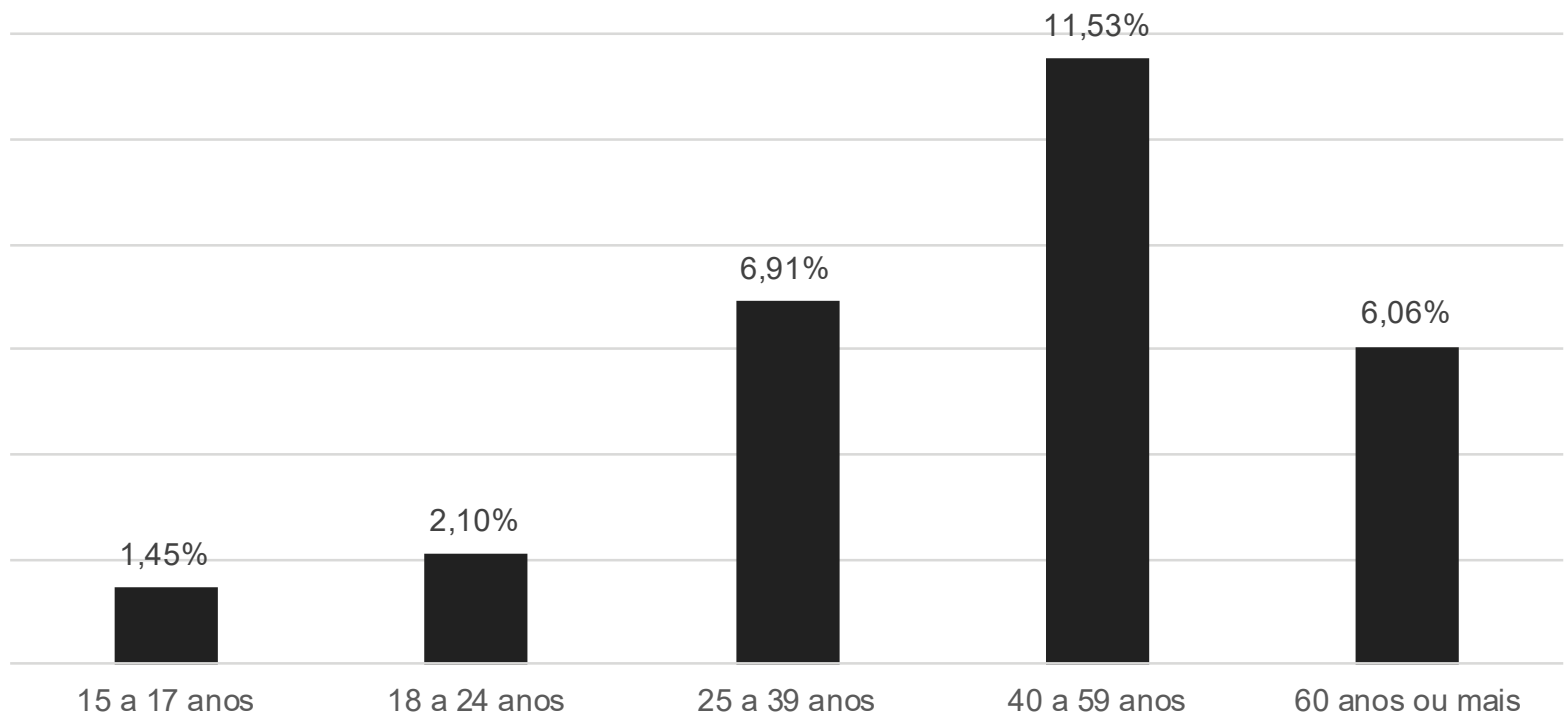

Fonte: IBGE. Elaboração própria.

Figura 38 - Percentual de pessoas com 10 anos ou mais não alfabetizadas por faixa etária, com relação ao total da população.

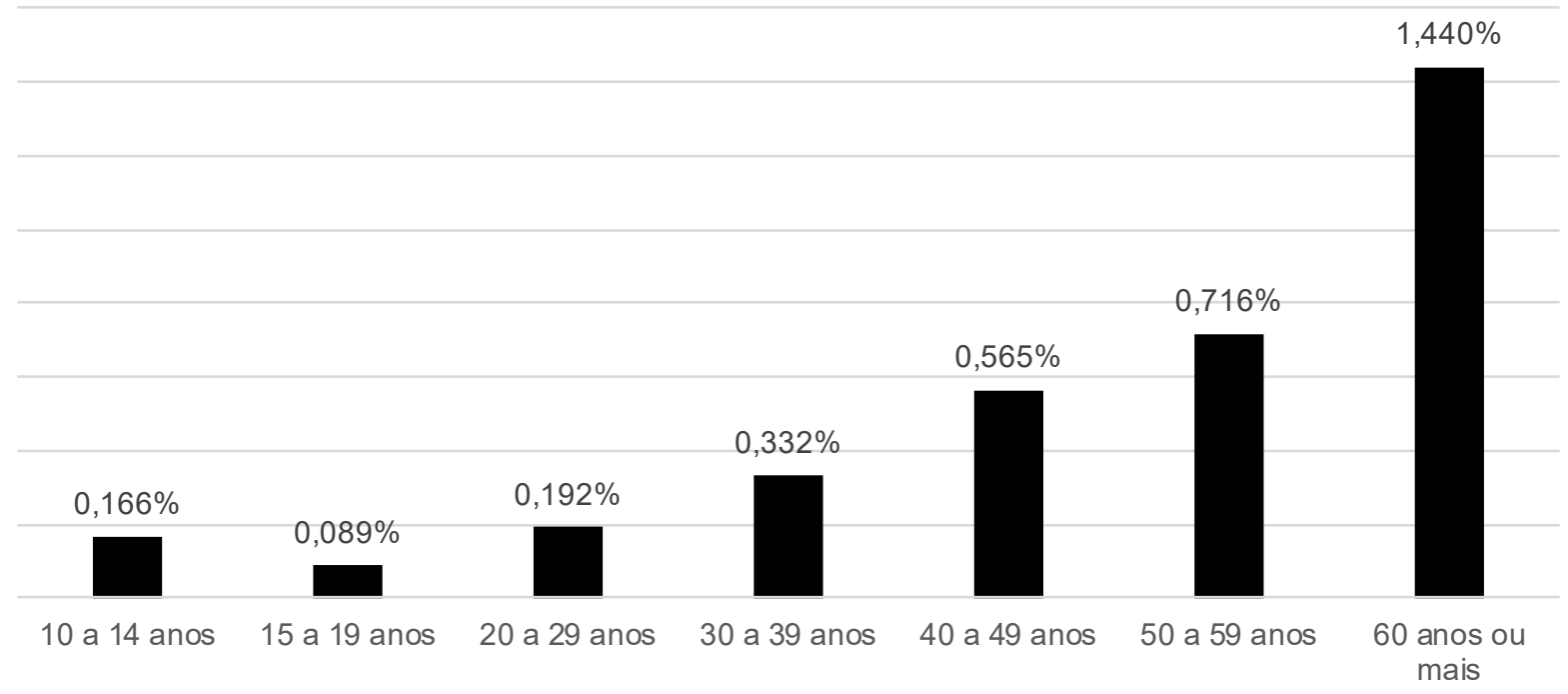

Fonte: IBGE. Elaboração própria.

Entre aqueles com mais de 25 anos, nota-se a redução da população sem ensino fundamental completo e aumento daqueles com ensino superior. Em 2000, 60\% dessa fatia da população não tinha ensino fundamental completo, o que passou a 42\% em 2010 (figura 40). 
No mesmo período, aqueles com ensino superior passaram de $3,38 \%$ para $7,16 \%$ da população com mais de 25 anos (figura 41).

Figura 39 - Percentual de pessoas de 10 anos ou mais não-alfabetizadas.

$7,64 \%$

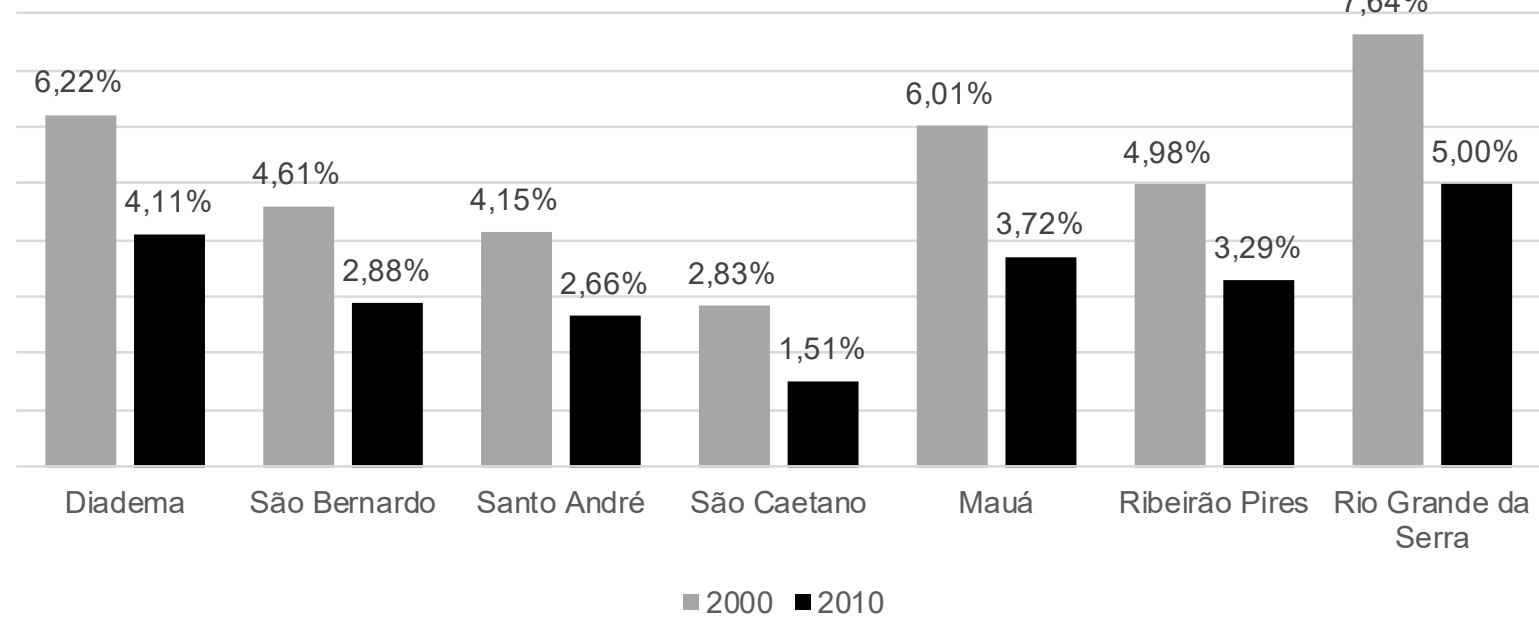

Fonte: IBGE

Figura 40 - Percentual de pessoas de 25 anos ou mais sem instrução ou com fundamental incompleto. 2000 e 2010 .

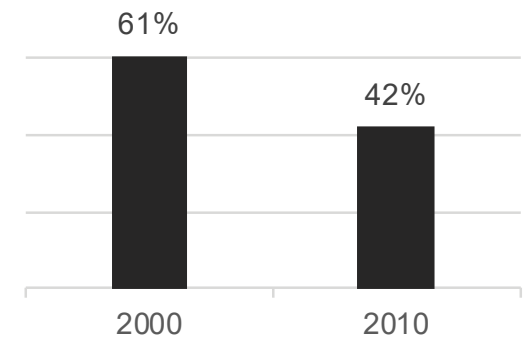

Fonte: IBGE. Elaboração própria.
Figura 41 - Figura 40 - Percentual de pessoas de 25 anos ou mais com nível superior. 2000 e 2010.

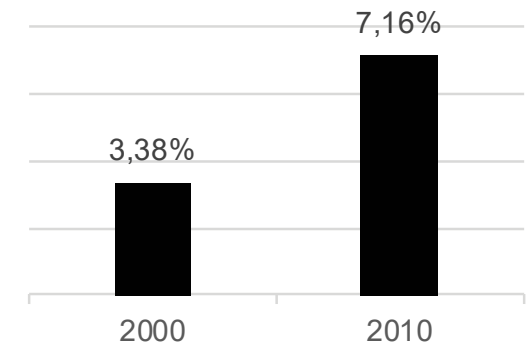

Fonte: IBGE. Elaboração própria.

Sem dúvidas, os resultados são frutos das políticas municipal, para o primeiro caso, e federal, no segundo. Este é, especificamente, resultado da ampliação da oferta de vagas no ensino superior particular, assim como do financiamento público, mas ainda não da presença de universidades federais na região, pois estas foram instaladas em 2007.

Ainda assim, Diadema ainda figura entre os índices quantitativos mais baixos do grande ABC. Dentre a população com mais de 25 anos, 41,98\% tem nenhum estudo ou apenas fundamental incompleto, $18 \%$ tem fundamental completo ou médio incompleto, $31,5 \%$ tem ensino médio completo ou superior incompleto, como indicado na figura 42. 
Figura 42 - Percentual da população com 25 anos ou mais por grau de instrução em 2010.

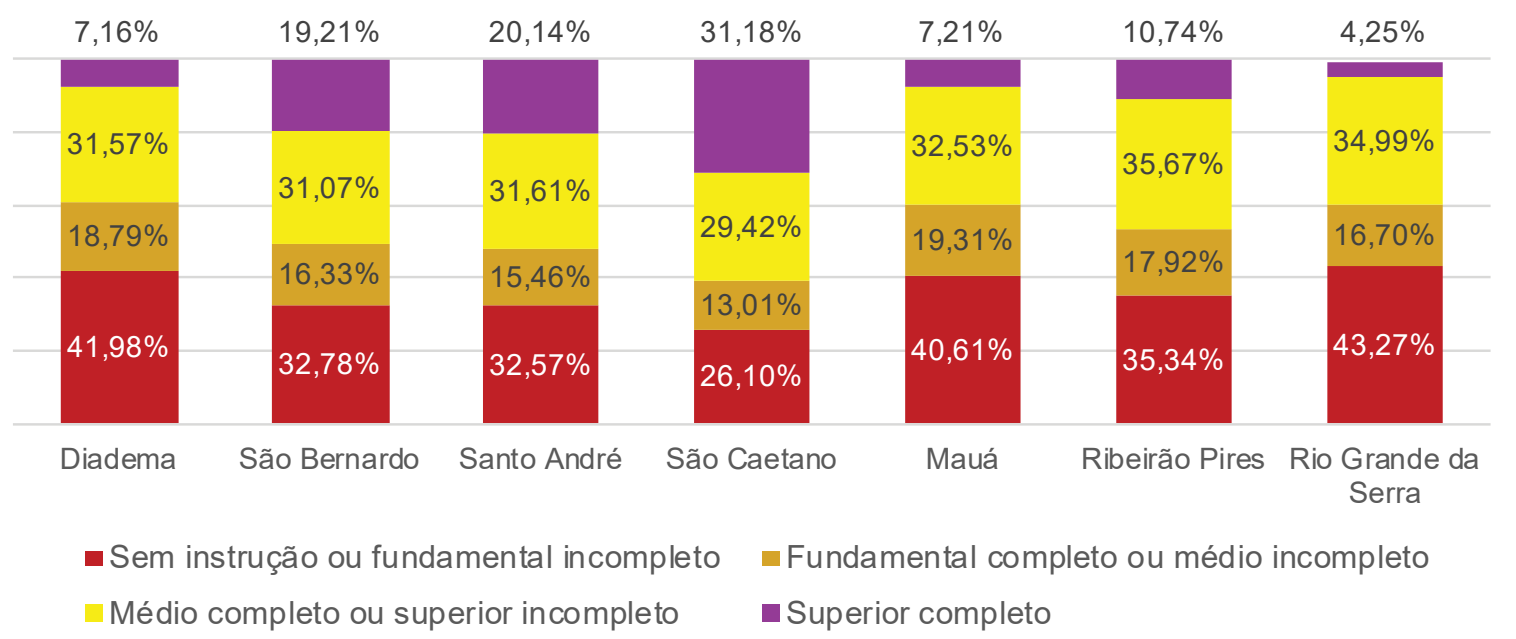

Fonte: IBGE. Elaboração própria.

Esse quadro poderia ser alterado através da capacidade de o município reter os estudantes e tê-los como moradores após sua formatura, e também pela atração de docentes e técnicos. Essa sugestão foi feita por Baumgartner (2015) que entende que a universidade possa provocar uma alteração na composição social das regiões onde se instala. No entanto, não se realizou um estudo sobre o local de moradia dos estudantes egressos, tampouco sobre a intenção de residir em Diadema entre os graduandos após sua formatura.

Por outro lado, um estudo realizado por dois estudantes egressos do campus Diadema como trabalho de conclusão de curso, intitulado de "Ocupação dos egressos do curso de Engenharia Química da Universidade Federal de São Paulo" (GIARDINI e SANCHES, 2016), avaliou que $83 \%$ dos ex-alunos do curso de engenharia química permaneceram na RMSP, sem especificar os municípios, 9\% mudaram-se para fora da metrópole, mas ainda no Estado de São Paulo, e $8 \%$ foram para outros estados.

Já entre técnicos e docentes, avaliou-se que poucas pessoas optaram por se mudar para Diadema $^{21}$. Por ora, o que interessa é que o próximo senso não indicará uma mudança no percentual de pessoas com ensino superior motivado pelo emprego de técnicos e docentes no campus Diadema, ou seja, não haverá uma alteração do quadro social como sugerido por Baumgartner (2015).

Uma terceira hipótese seria que o campus fosse amplamente acessado pela população local. Infelizmente, não foi possível ter acesso à pesquisa do campus que aponta a origem dos seus estudantes por município. Por outro lado, os dados públicos consideram como unidade a 21 Essa informação será detalhada no capítulo 3, no item 3.5. 
RMSP. Entretanto, em conversas informais, assim como nas entrevistas com o Entrevistado 4 e com o professor José Alves, assim como com o ex-prefeito José de Filippi Jr, foi mencionado que os estudantes do campus não provêm de Diadema, na sua maioria absoluta.

Essa informação, confrontada com o que se expos há pouco sobre a evolução do IDHM e a ampliação do acesso ao ensino fundamental e médio, permitem considerar que o aumento da escolaridade não bastou para garantir o acesso à universidade púbica. A explicação para isso é que os dados avaliados são meramente quantitativos e não consideram a qualidade do ensino, sobretudo a competição com estudantes de outras regiões, já que o vestibular é nacional.

Apesar disso, alguns dados do Ideb - Índice de Desenvolvimento da Educação Básica nos permitem observar que há uma mudança qualitativa em curso, mas ainda insuficiente para a ampliação do acesso à graduação na universidade pública entre os jovens de Diadema. Apesar das suas limitações, os dados permitem um panorama geral a respeito do nível de aprendizado dos estudantes de escolas públicas, que em Diadema representa $90 \%$ dos jovens com entre 10 e 14 anos, faixa etária de aplicação da Prova Brasil, que compõe o Ideb.

De acordo com esses dados, $70 \%$ dos estudantes do $5^{\circ}$ ano apresentaram desempenho considerado "aprendizado adequado" 22 na prova de português em 2015. Em 2011 eram apenas 48\%. Em comparação com outros municípios do ABC, Diadema acompanhou a evolução, mas ainda se manteve atrás dos demais, é o que indica a figura 43 .

Já entre os estudantes do $9^{\circ}$ ano, a porcentagem daqueles com "aprendizado adequado" foi de 35\%, também com evolução com relação aos 24\% de 2011. Neste dado, Diadema encontra-se mais próximo da condição dos municípios vizinhos, como mostra a figura 44.

Por outro lado, os dados da prova de matemática indicavam $43 \%$ de "aprendizado adequado" em 2011, e 61\% em 2015, para o $5^{\circ}$ ano. Para o $9^{\circ}$ ano eram 9\% em 2011 e $13 \%$ em 2015. Em ambos, Diadema acompanhou a evolução dos outros municípios, mas ainda se mantém aquém, de acordo com as figuras 45 e 46.

22 "Na Prova Brasil, o resultado do aluno é apresentado em pontos numa escala (Escala SAEB). Discussões promovidas pelo comitê científico do movimento Todos Pela Educação, composto por diversos especialistas em educação, indicaram qual a pontuação a partir da qual pode-se considerar que o aluno demonstrou o domínio da competência avaliada. Decidiu-se que, de acordo com o número de pontos obtidos na Prova Brasil, os alunos são distribuídos em 4 níveis em uma escala de proficiência: Insuficiente, Básico, Proficiente e Avançado. No QEdu, consideramos que alunos com aprendizado adequado são aqueles que estão nos níveis proficiente e avançado.” (Retirado de <https://academia.qedu.org.br/prova-brasil/aprendizado-adequado/>. Acesso em 24/09/2018). 
Figura 43 - Porcentagem de estudantes da rede pública com desempenho considerado "aprendizado adequado" na Prova Brasil - Português, $5^{\circ}$ ano. 2011, 2013 e 2015.

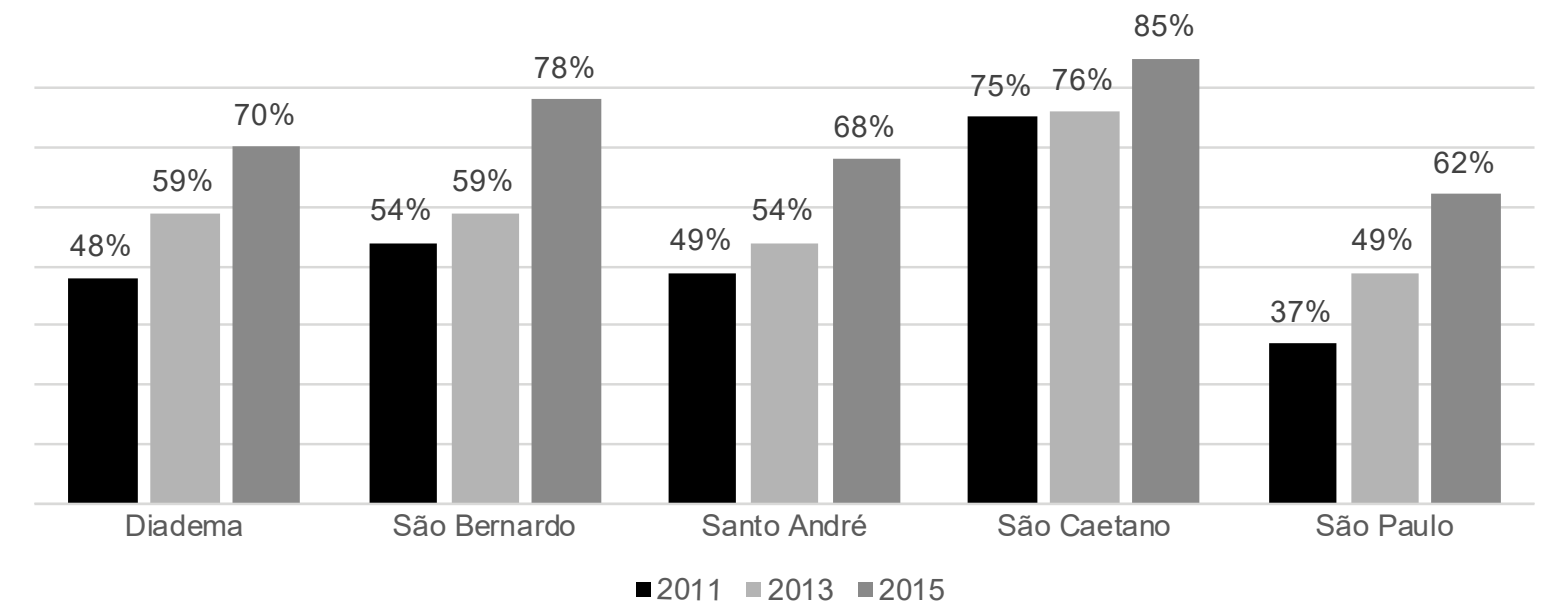

Fonte: Ideb - Prova Brasil. Elaboração própria.

Figura 44 - Porcentagem de estudantes da rede pública com desempenho considerado "aprendizado adequado" na Prova Brasil - Portugues $9^{\circ}$ ano.

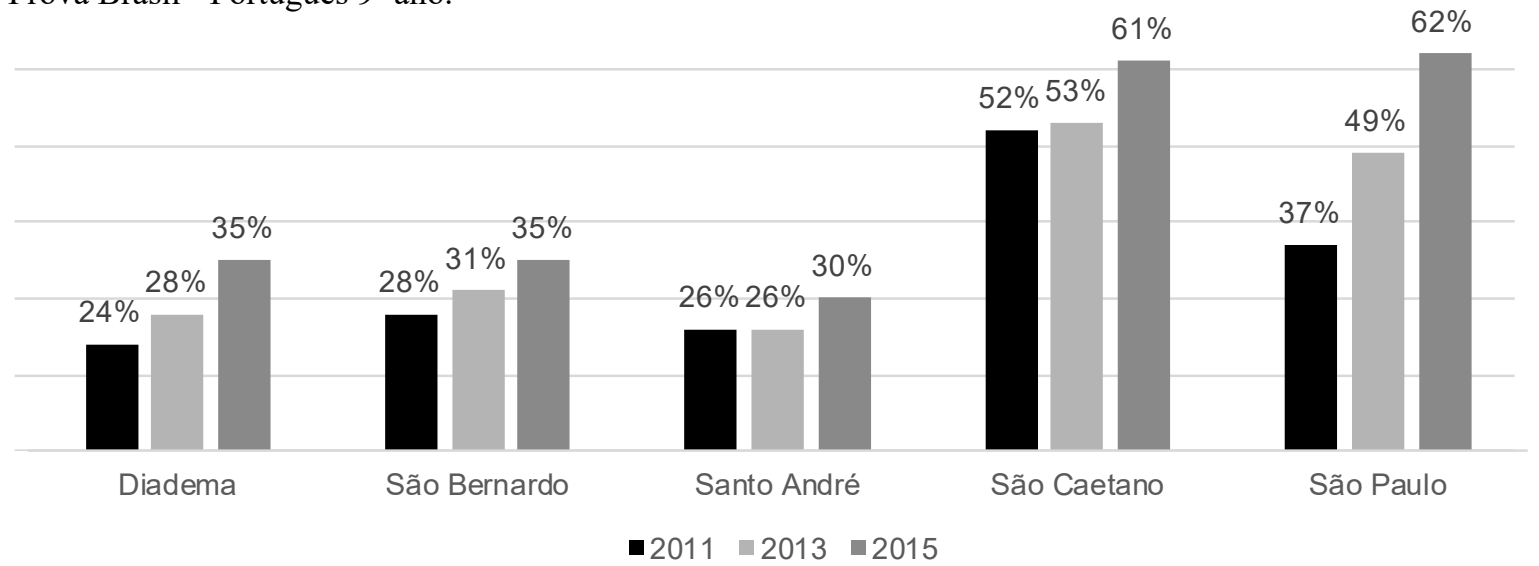

Fonte: Ideb - Prova Brasil Elaboração própria.

Figura 45 - Porcentagem de estudantes da rede pública com desempenho considerado "aprendizado adequado" na Prova Brasil - Matemática $5^{\circ}$ ano.

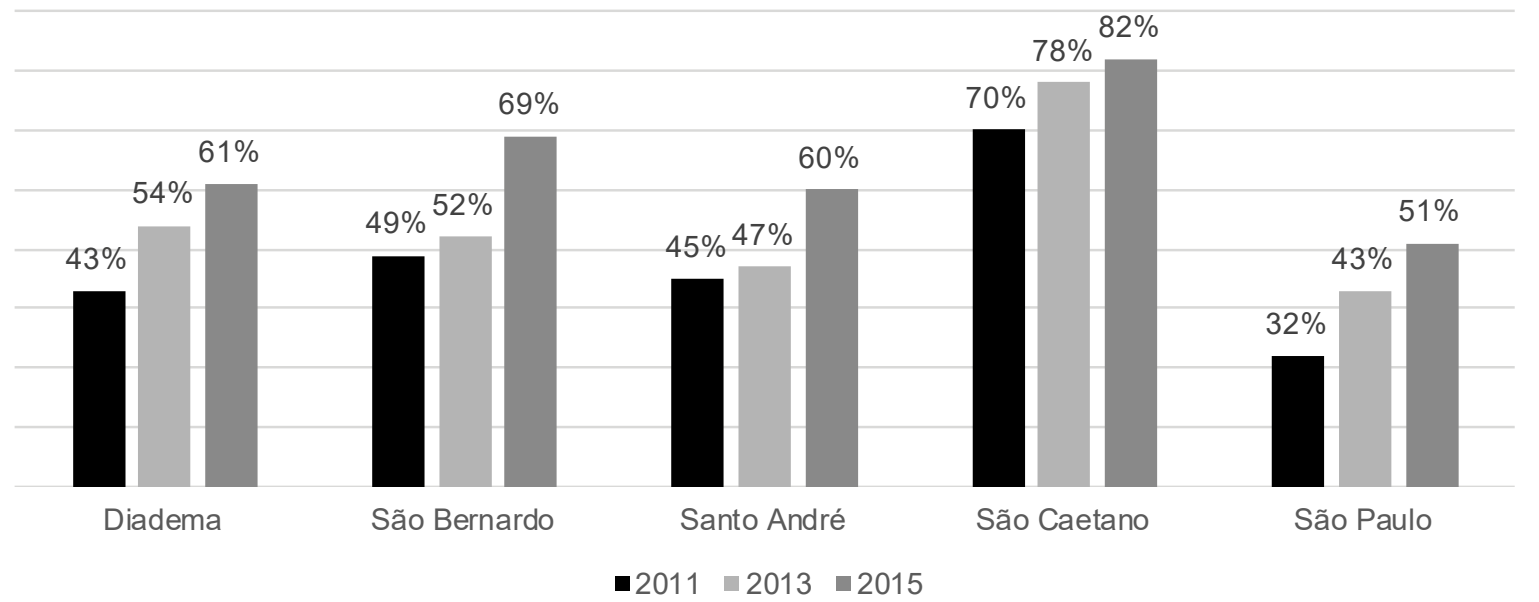

Fonte: Ideb - Prova Brasil Elaboração própria. 
Figura 46 - Porcentagem de estudantes da rede pública com desempenho considerado "aprendizado adequado" na Prova Brasil - Matemática $9^{\circ}$ ano.

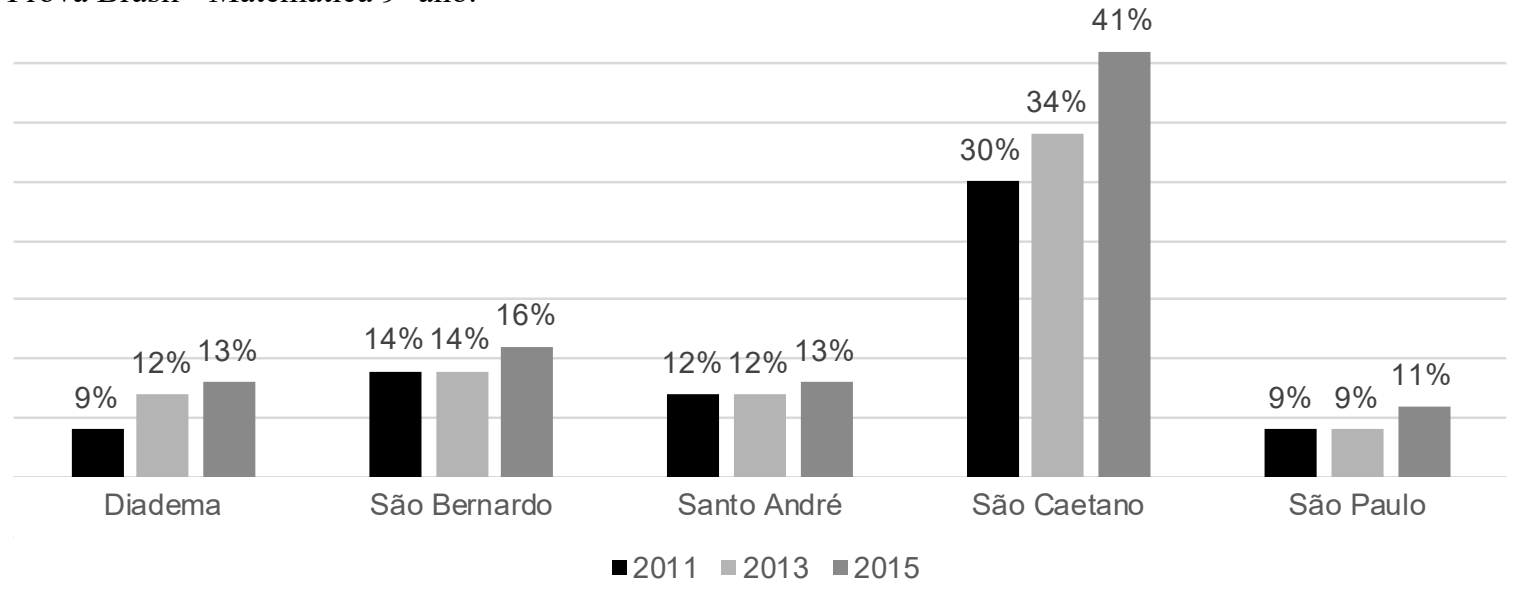

Fonte: Ideb - Prova Brasil. Elaboração própria.

Portanto, ainda que os dados apresentem limitações, é possível apreender que existe uma defasagem de aprendizado já desde o ensino fundamental que compromete o desempenho de $90 \%$ dos estudantes de Diadema e sua concorrência no Enem para o acesso às universidades federais, o que significa que a universidade não pode cumprir com o desígnio de capacitar a mão-de-obra local. Entretanto, o campus Diadema tem atuado diretamente sobre esta questão. 


\section{O CAMPUS DIADEMA}

O campus Diadema iniciou suas atividades em 2007, portanto, é fruto do primeiro programa de expansão universitária (2003-2007) e ampliou-se durante o programa Reuni, lançado no mesmo ano. Sua curta história é marcada por uma crise perene motivada, principalmente, por deficiências de infraestrutura e insuficiência de espaço e infraestrutura adequada para abrigar suas atividades.

Hoje, o campus está dividido em 5 unidades: José de Filippi ${ }^{23}$, Antônio Doll, Oficina Mecânica (Manoel da Nóbrega), Florestan Fernandes e José de Alencar. Além dessas, o campus ainda tem a seu dispor um terreno à beira da Represa Billings, chamado de Sítio Morungaba, conforme figura 47 , abaixo.

Figura 47 - Localização das unidades do campus Diadema.

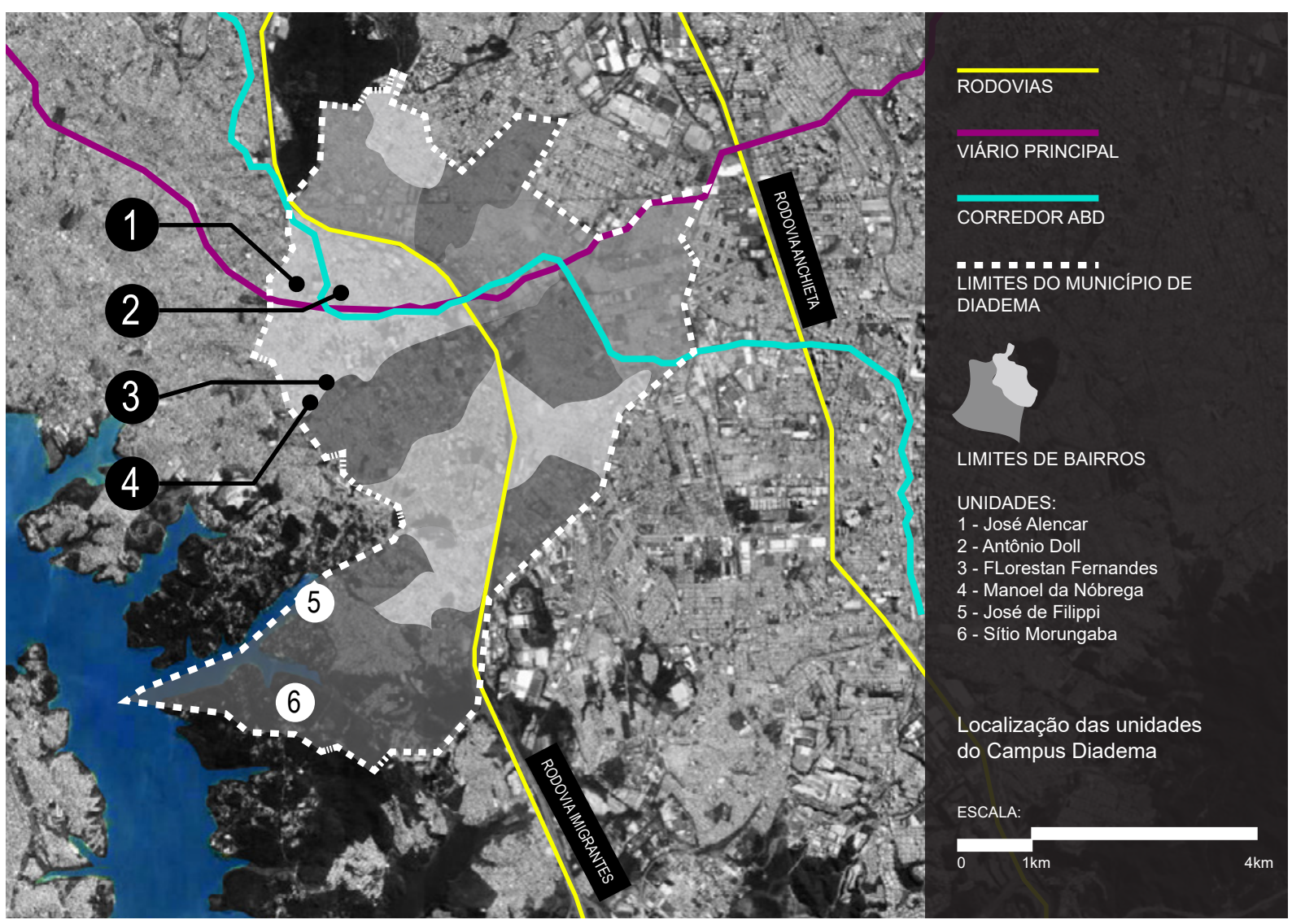

Fonte: Google Earth. Elaboração própria.

23 O nome da unidade é uma homenagem ao pai do ex-prefeito, José de Filippi Junior, ligado à Escola Paulista de Medicina, que deu origem à Unifesp. 
A unidade José de Filippi concentra atividades de laboratórios, tanto didáticos como de pesquisa (60 ao todo), anfiteatro e restaurante universitário. É a unidade que deu origem ao campus, no bairro do Eldorado, marcado por grande desigualdade, dada a ocupação com favelas urbanizadas e não urbanizadas, assim como condomínios fechados à beira da represa Billings, na porção sul do município. A figura 48 apresenta a inserção urbana da unidade.

Figura 48 - Inserção urbana da unidade José de Filippi.

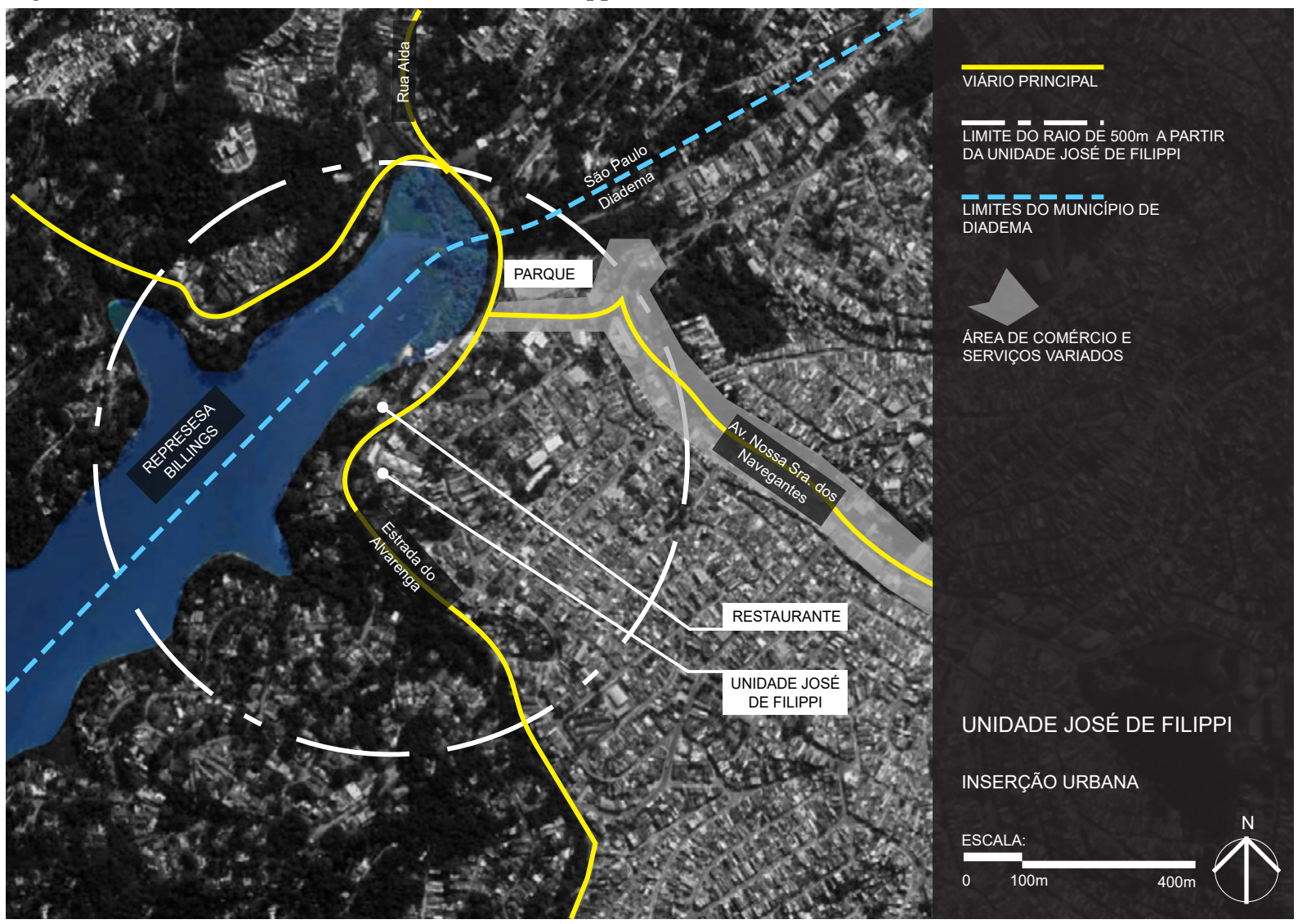

Fonte: Google Earth. Elaboração própria.

Esta unidade é um conjunto de 4 edificações (Galpão de Pesquisas, Edifício Didático, Ed. De Anfiteatro e Refeitóio), que outrora já abrigaram um centro cultural e, anteriormente, um hospital psiquiátrico. Por isso, guarda na sua arquitetura vestígios de seus outros usos.

As unidades Manoel da Nóbrega - Oficina Mecânica - e Antônio Doll são alugadas e carregam o nome das ruas onde estão, no centro de Diadema. A primeira é um sobrado dedicado a atividades de pesquisas na área de materiais, que sofre com a insuficiência de suas instalações. A segunda é uma sobreloja ao lado do terminal Diadema onde se concentram salas de aula e uma parte da administração, o NAE, Núcleo de Apoio ao Estudante e salas de parte dos docentes da licenciatura em ciências. Ambas têm características marcantes de edificações autocons- 
truídas, sem projeto de arquitetura, sobretudo dimensionamentos irregulares e não atendimento às normas de edificações.

A unidade Florestan Fernandes é um edifício à rua Manoel da Nóbrega, cedido parcialmente pela prefeitura, que abriga a fundação de mesmo nome, mantida pela prefeitura. Nesta unidade estão salas de aula, biblioteca e restaurante universitário. A universidade ocupa parcialmente o térreo e os dois andares superiores enquanto a fundação ocupa os andares inferiores. $\mathrm{O}$ teatro, no térreo, é de uso compartilhado. A inserção urbana da unidade está na figura 49, onde tambem aparece a unidade Manoel da Nóbrega.

Figura 49 - Inserção urbana das unidades Florestan Fernandes e Manoel da Nóbrega (oficina mecânica).

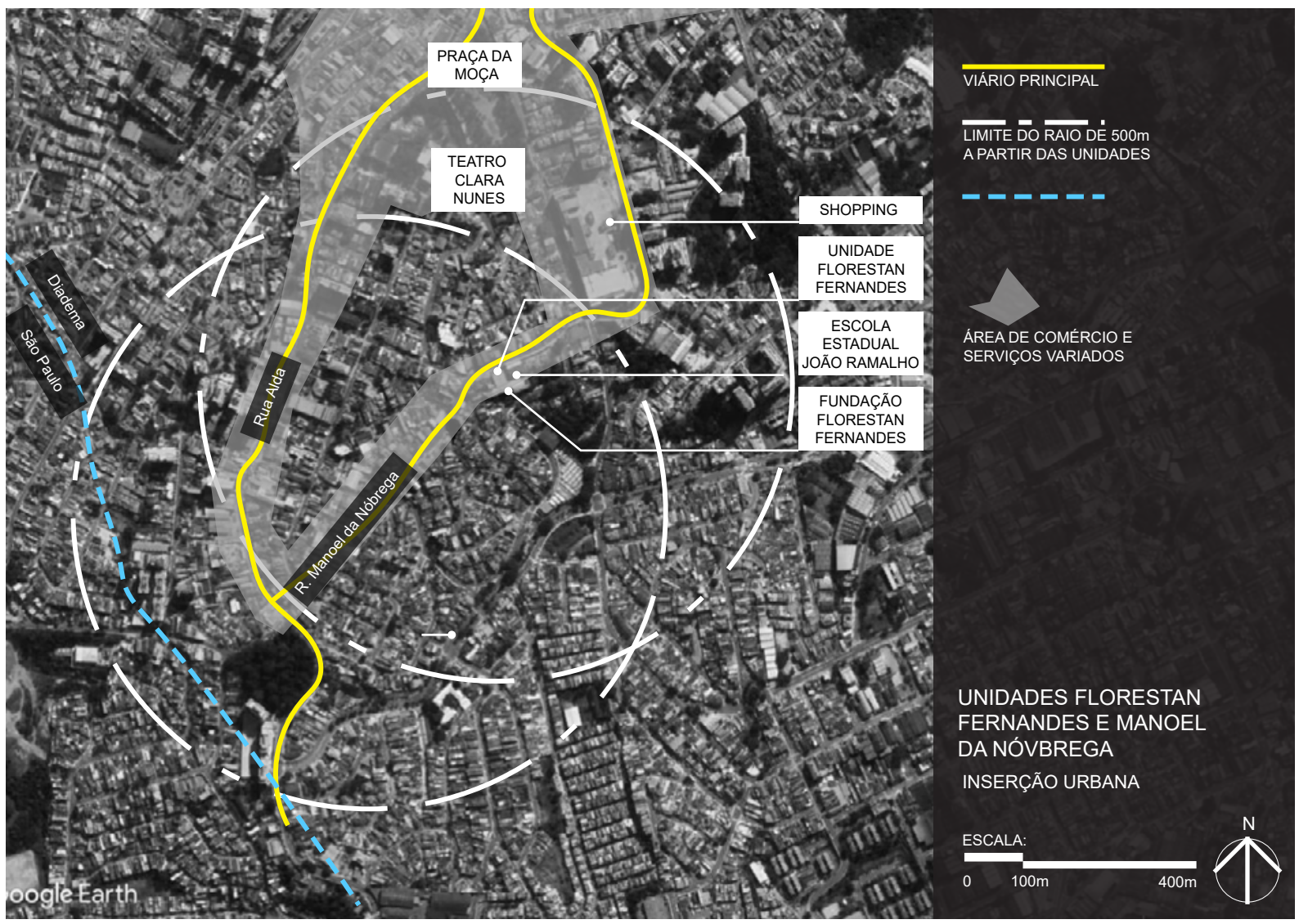

Fonte: Google Earth. Elaboração própria.

Já a unidade José de Alencar é separada em dois lotes. O edifício de Vidro, na porção mais baixa é a sede do campus e dá lugar à maior parte da administração, assim como a laboratórios didáticos e de pesquisa. A porção mais alta da unidade José de Alencar, chamada de Complexo Didático, contém um pequeno edifício de 16 salas de aula, parte da administração, espaços de uso dos estudantes e restos de edifícios industriais demolidos. A inserção urbana desta unidade e da unidade Antônio Doll estão representadas na figura 50. 
Figura 50 - Inserção urbana das unidades Florestan Fernandes e Manoel da Nóbrega (oficina mecânica).

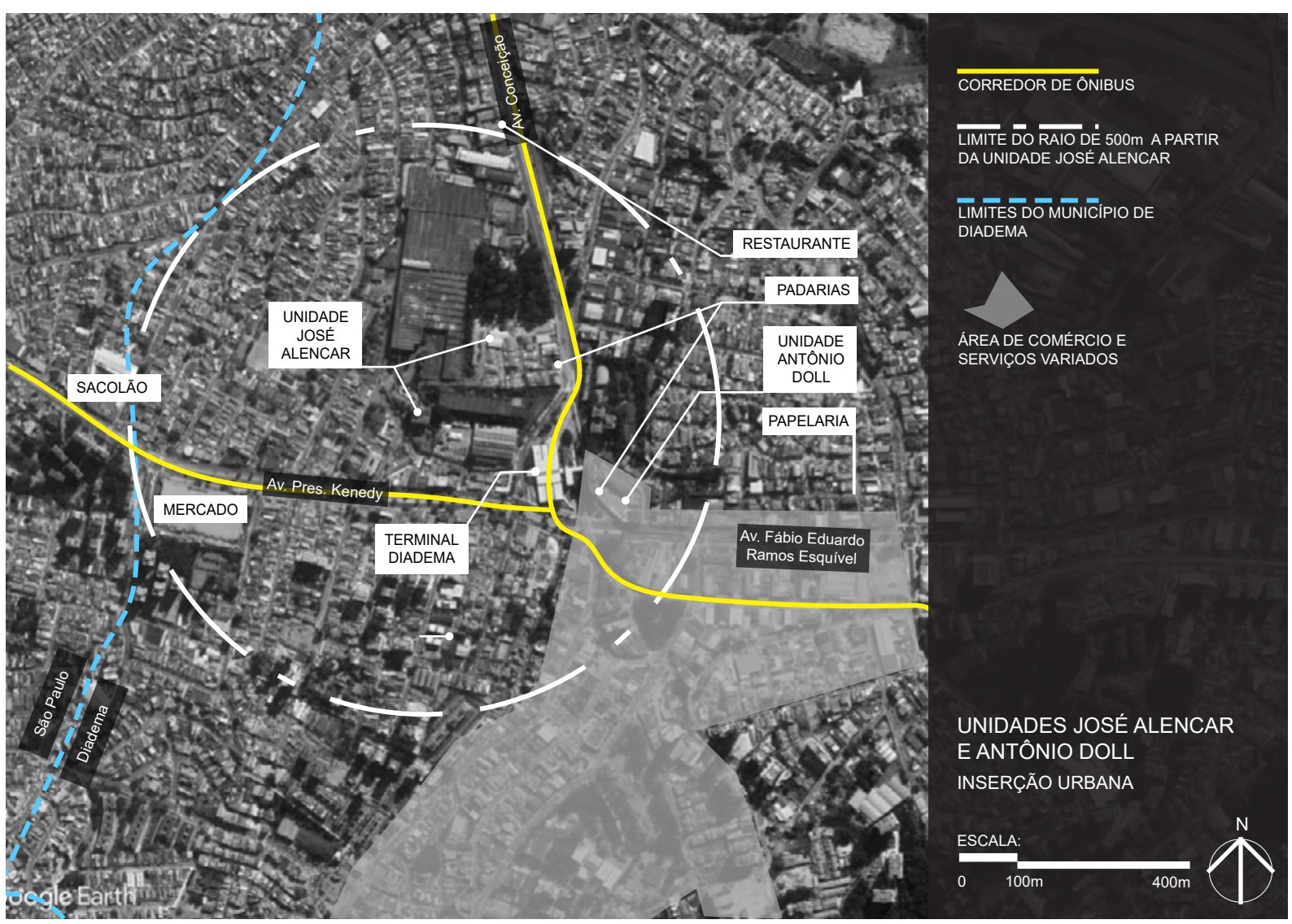

Fonte: Google Earth. Elaboração própria.

Estes terrenos foram adquiridos pela União de parte da massa falida de um conglomerado industrial, que contava com indústrias de plástico, tintas, produtos químicos e metalúrgica. Esta última é a única ainda em atividade por meio da Cooperativa Central de Produção Industrial de Trabalhadores em Metalurgia - Uniforja - que teve origem a partir da extinta Confor$\mathrm{ja}^{24}$. A divisão de lotes entre Unifesp e Uniforja pode ser verificada na imagem 42.

O lote mais baixo, acessado pela rua São Nicolau, não tem entrada própria. Servidores, funcionários terceirizados e estudantes têm que acessar o Edifício de Vidro a partir da portaria da Uniforja, o que representa um conflito, já que a indústria tem maior rigidez na circulação e no controle do acesso.

Por outro lado, a proximidade é um facilitador no relacionamento entre cooperativa e universidade. Hoje há propostas de parcerias em desenvolvimento, que aguardam as ampliações do laboratório de materiais, hoje instalado na unidade Manoel da Nóbrega. Parte desta

24 A Conforja foi uma indústria de metalurgia estabelecida em 1968, cuja falência foi decretada em 1999. Chegou a representar $70 \%$ do mercado até o governo Collor, quando foi aberta a concorrência com empresas estrangeiras. Chegou a ser a única fornecedora de tubulações e conexões em aço para a Petrobras e viveu seu período áureo com o "milagre econômico" na década de 1970 (SINGER, 2005). 
parceria é a cessão de um galpão da indústria para abrigar um laboratório de pesquisa com trabalhos conjuntos, e aguarda viabilidade.

Figura 51 - Unidade José Alencar da Unifesp e divisas com a Uniforja.

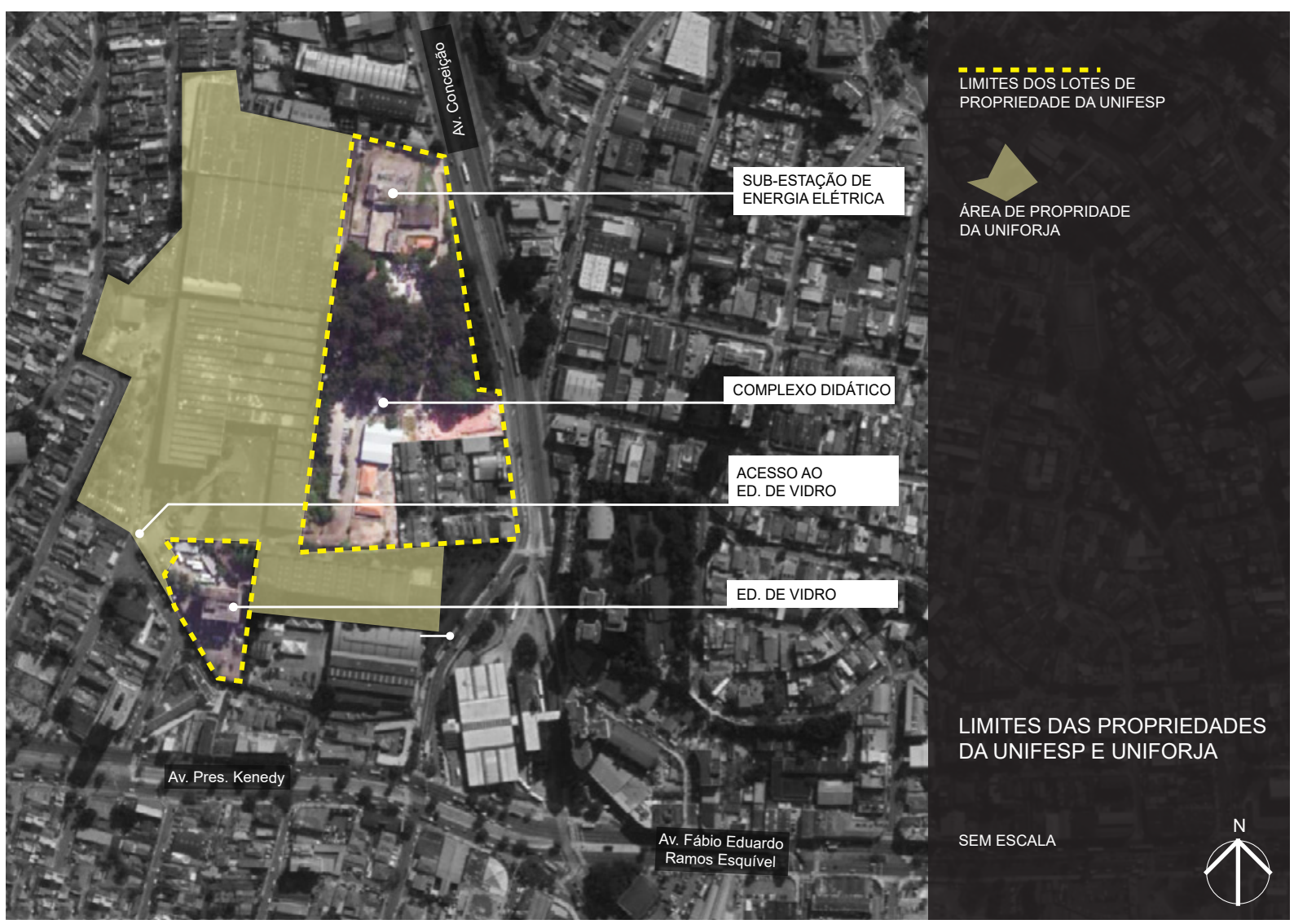

Fonte: Google Earth. Elaboração própria.

Também é nessa unidade que o campus planejou sua expansão em duas etapas, através do Plano Diretor de Infraestrutura - PDInfra. A primeira fase prevê a construção de três edifícios: Bloco Norte (edifício de 11 andares dedicados exclusivamente a laboratórios de pesquisa e ensino), Biblioteca/Auditório e Edifício de Acesso (salas de aula e partes da administração voltadas à área acadêmica, como secretaria de graduação). O plano de expansão está apresentado na figura 52, a seguir.

Todos esses três edifícios têm projeto executivo, entretanto, apenas o edifício de acesso está em obras. A segunda fase da expansão conta com mais três edifícios dedicados a salas de aula, laboratórios de pesquisa e ensino, e à extensão.

É em meio a esta fragmentação que o campus

oferece sete cursos de graduação (Ciências Ambientais, Ciências Biológicas, Engenharia Química, Farmácia e Bioquímica, Licenciatura Plena em Ciências, Química e Química Industrial), nos quais estão matriculados 2.549 estudantes. Em nível de 
pós-graduação stricto sensu, estão em vigência seis programas de pós-graduação, com 161 inscritos: Biologia Química, Ciência e Tecnologia da Sustentabilidade, Ecologia e Evolução, Biotecnologia, Engenharia e Ciência de Materiais e Análise Ambiental Integrada. (Disponível em $<$ http://www.unifesp.br/campus/dia/institucional/apresentacaodia $>$. Acesso em 18/12/2018)

Figura 52 - Plano de expansão do Campus Diadema.

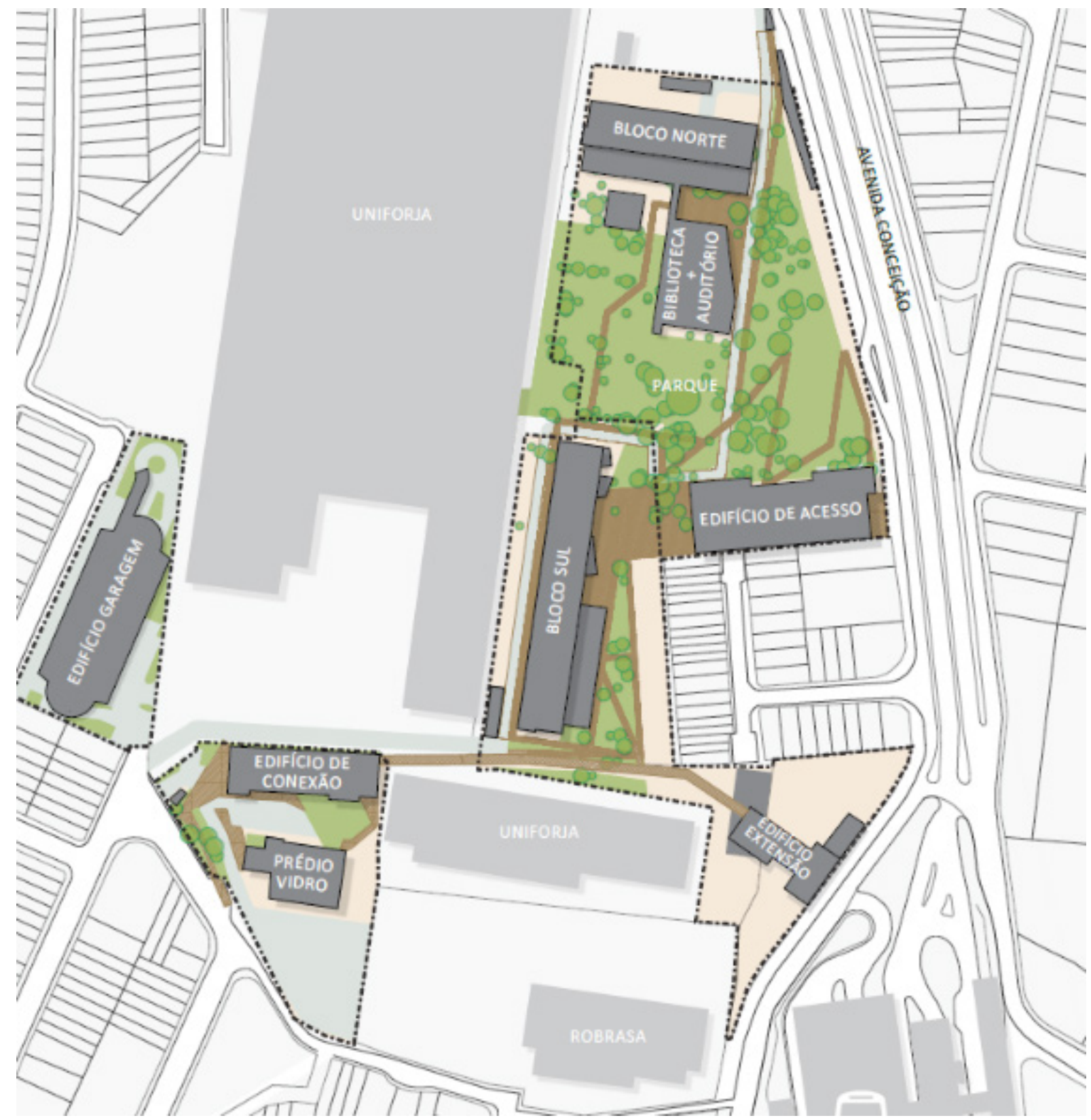

Fonte: PDInfra Unifesp. Disponível em $<$ https://www.unifesp.br/reitoria/proplan/pdinfra/pdinfra-titulo/campusdiadema/plano-diretor-documentacao-completa>. Acesso em 04/01/2018

Esses cursos se sobrepõem à realidade econômica, física e social do município. A parte de licenciatura relaciona-se diretamente com a fragilidade social, sobretudo com o baixo desempenho dos estudantes nas avaliações nacionais. Já os cursos de ciências ambientais e 
biológicas são diretamente ligados à questão ambiental devido à presença de área de proteção aos mananciais, em parte significativa, do município. Por outro lado, os cursos de Engenharia Química, Farmácia, Química, Química Industrial e Bioquímica se espelham nas indústrias do município e da região.

\subsection{Histórico do Campus Diadema:}

A origem do campus Diadema remonta à luta por uma universidade no $\mathrm{ABC}$, na década de 1960, durante o governo de João Goulart (1961-1964). Naquela época, os movimentos sociais tinham uma pauta de reivindicações que iam desde questões trabalhistas até a defesa de uma universidade pública para a região, passando por questões de habitação e urbanas. (CARVALHO, 2011).

A ideia de uma universidade para o $\mathrm{ABC}$ ganhou força quando da promulgação da constituição do Estado de São Paulo, em 1989, que traz no seu artigo 52 o embrião legal para a constituição da instituição:

\footnotetext{
ARTIGO 52 - Nos termos do artigo 253 desta Constituição e do artigo 60, parágrafo único do Ato das Disposições Constitucionais Transitórias da Constituição Federal, o Poder Público Estadual implantará ensino superior público e gratuito nas regiões de maior densidade populacional, no prazo de até três anos, estendendo às unidades das universidades públicas estaduais e diversificando os cursos de acordo com as necessidades sócio-econômicas dessas regiões.

Parágrafo único - A expansão do ensino superior público a que se refere o "caput" poderá ser viabilizada na criação de universidades estaduais, garantido o padrão de qualidade. (CONSTITUIÇÃO DO ESTADO DE SÃO PAULO).
}

Uma universidade para o $\mathrm{ABC}$ foi legalmente criada em 1995, através da lei 9.083, que instituía a "Universidade Estadual do Grande ABC", muito embora isto jamais tenha se concretizado. Esta universidade teria sede em Santo André e campi espalhados pelos municípios vizinhos.

Dessa luta surgiram algumas instituições privadas, como a Faculdade de Direito de São Bernardo do Campo e a Faculdade de Medicina do $\mathrm{ABC}$, que originalmente, eram o embrião da universidade pública que se criaria, além da Universidade Municipal de São Caetano (CARVALHO, 2011). A não concretização da Universidade Estadual do Grande ABC (e nenhuma outra 
até 2007, quando se fundou a Universidade Federal do ABC - UFABC) fez com que aquelas instituições se mantivessem até hoje em dia.

Com a expansão das universidades federais, a partir de 2003, a pauta ganhou novo fôlego. A decisão de criar uma universidade no ABC veio já em 2004. Fernando Haddad, então secretário executivo do MEC, em recente entrevista à revista Piauí, lembra que, à época, solicitou ao então presidente, Luís Inácio Lula da Silva, que investisse em uma universidade federal para São Paulo, como parte do pagamento de uma dívida histórica da federação para com a região:

E quando Lula me encomendou o maior plano de expansão da rede federal de educação superior e profissional, com universidades e escolas técnicas que interiorizamos pelo país, fiz questão de lembrá-lo da pouca presença federal no principal estado da federação. Ele então questionou: "Mas São Paulo precisa? Já tem a USP, a Unicamp, a Unesp, a Fundação Paula Souza..." Insisti: "Mas não tem rede federal." Assim, criamos a Universidade Federal do $\mathrm{ABC}$, a Unifesp foi expandida pela região metropolitana e a UFSCar, pelo interior de São Paulo. (HADDAD, 2017. Disponível em < https://piaui.folha.uol.com.br/materia/vivi-na-pele-o-que-aprendi-nos-livros/>; Acesso em 20/02/2019)

Ao saber da tramitação da proposta, o então reitor da Unifesp, Ulysses Fagundes Neto, contatou o MEC para manifestar o interesse da universidade em liderar o processo para a nova universidade no $\mathrm{ABC}$ e levou a proposta ao Conselho Universitário, que a aprovou, como consta em ata. A proposta incluía a retirada de um projeto de lei, em tramitação naquela altura, que criaria uma universidade nova para o ABC. Assim, ao invés de criar a Universidade do ABC, a Unifesp iniciaria sua expansão com novos campi.

Sr. Reitor relatou que no mês de maio leu, em jornal de grande circulação, a notícia da criação da Universidade do ABC e juntamente com Prof. Sérgio Tufik contataram Brasília, declarando interesse em participar do processo. (...) Vários professores parabenizaram o Sr. Reitor (...) e se posicionaram a favor da expansão do Campus da Unifesp (...) Sr. Reitor solicitou então aprovação da proposta do Prof. Rubens, salientando a importância da retirada do projeto que tramita na Câmara Federal e que tem por objetivo a criação da Universidade do $\mathrm{ABC}$, para que a Unifesp continue com as negociações de implantação, o que foi aprovado pelos presentes, com uma abstenção. (Ata Conselho Universitário de 10/11/04).

À época, o prefeito de Diadema era José de Filippi Junior, que lembra, em entrevista, que o governo federal se antecipou e criou a Universidade do ABC com o nome de Universidade Federal do ABC - UFABC - com sede em Santo André. Segundo ele, o principal agente desse movimento foi o então líder do governo, professor Luisinho, que teria decidido retomar a proposta da universidade para o $\mathrm{ABC}$, agora como uma universidade federal.

O líder do governo do presidente Lula, em 2005, era o professor Luisinho, que era deputado estadual nesse período em que se tinha a luta pela universidade do ABC. Então, ele era um protagonista, uma pessoa totalmente inserida nessa disposição, nessa 
luta, nesse objetivo, o ABC ter a sua universidade pública. E ele, como líder, vendo que em 2004 e 2005 já havia um ambiente mais propício para a gente sonhar, para a gente estabelecer propostas mais ousadas de ampliação dos campi das universidades federais ele fez essa proposta. (Entrevista. José de Filippi Junior, 19/07/2018).

Para Filippi Jr., a decisão do governo federal tem caráter simbólico forte, porque a região era, e ainda é, reduto político do ex-presidente Lula, e até mesmo do próprio professor Luisinho, além de que, de alguma forma, concretizava uma pauta de décadas de lutas; era importante para o $\mathrm{ABC}$ ter uma universidade com o seu nome.

a UFABC não poderia ser substituída por um campus da Unifesp, uma expansão. Ela precisaria ter personalidade por conta dessa história. (...) tem que nascer com um novo $\mathrm{RG}$, com personalidade própria, com cara própria, com sua própria digital, não pode ser do outro, emprestado. (Entrevista. José de Filippi Junior, 19/07/2018).

A decisão do ministério foi comunicada ao Conselho Universitário da Unifesp em março de 2005, portanto, quatro meses depois, junto ao anúncio de uma nova possibilidade, a de instalar um campus em Diadema.

[O reitor] relatou que em audiência no dia anterior com o Ministro da Educação, Tarso Genro e outras autoridades. O Ministro ressaltou a contribuição da Unifesp para o crescimento do país, entretanto comunicou que estaríamos fora do processo de implantação da Universidade do ABC. (...) Informou que no dia 03/03 recebeu o Sr. José de Fillipi [Júnior], Prefeito de Diadema, que nos convidou para implantar a Universidade naquele município. (Ata Conselho Universitário de 09/03/2005).

Filippi Jr. relata essa proposição da seguinte forma:

eu sabia que a UFABC ia nascer em Santo André, o segundo campus muito provavelmente ia ser São Bernardo, que são a primeira e a segunda cidade, são as duas mais importantes do ponto de vista econômico e de população. Eu falei: "bom, o dia que essa UFABC chegar em Diadema vai ser daqui 10, 20 anos (...) Então, propus pro Ulysses. Falei pro Ulysses: "D, fica no A-B-C-D, você não quer levar essa Unifesp para Diadema? (Entrevista. José de Filippi Junior, 19/07/2018).

Cabe considerar que a prefeitura de Diadema e Unifesp já mantinham um relacionamento desde 2001 quando foi firmado o primeiro convênio de cooperação entre universidade e secretaria de saúde, para implantação do programa "Saúde em Casa", formalizado pela lei municipal $n^{\circ}$ 2.082, de 07 de dezembro de 2001 (DIADEMA, 2001). Em 2002 o convênio foi ampliado pela lei municipal no 2.191, de 05 de dezembro de 2002 (DIADEMA, 2002), que tinha por objetivo a "implantação, coordenação e execução dos programas e ações de saúde".

Filippi Jr., ciente das movimentações políticas, da intenção de expansão da Unifesp e da negativa do MEC para que liderasse a universidade no $\mathrm{ABC}$, articulou com agentes locais e a câmara de vereadores o apoio para a criação de um campus da Unifesp no município. 
eu conversei com a minha equipe e falei o seguinte: “Gente, é o seguinte, não podemos brincar. Quando Diadema ia sonhar em ter uma universidade federal? O momento é agora, vamos nessa. Vamos lá.”. (...) fizemos um projeto de lei, aprovamos, e foi aí que nasceu. (...) eu tive o apoio fantástico e decisivo de toda a minha equipe, dos secretários, secretário de educação, secretário da nossa equipe, o presidente da câmara, os vereadores, a cidade, os empresários através do Ciesp.” ? (Entrevista. José de Filippi Junior, 19/07/2018).

Isso foi essencial para que a proposta tivesse sucesso. Segundo Filippi, a negociação passou ao ministério da educação, através do então ministro, Tarso Genro, com a promessa de dar o suporte físico para a criação do campus e foi aprovada pelo ex-presidente Lula:

Levamos o estudo para ele [Tarso Genro], levamos essa condição que a prefeitura ia dar todo o suporte, inclusive já dando o primeiro prédio para instalação e se comprometendo, depois, a arrumar um terreno. Arrumava o prédio para dar início logo dali 2, 3 anos os primeiros cursos, dar o suporte físico, político e todo o trabalho de "seja bem-vindo a Unifesp para Diadema" e um terreno para expansão. Quem deu a palavra final? Foi o presidente Lula. Então o Tarso Genro falou: “Tá muito bom, vou levar para ele. Ele que vai ter que decidir se vai." ? (Entrevista. José de Filippi Junior, 19/07/2018).

Dessa forma, em dezembro de 2005 a prefeitura deu dois passos para a concretização da universidade. No início do mês a prefeitura cedeu à União um terreno às margens da represa Billings, no bairro do Eldorado, conhecido como Sítio Morungaba, local onde o campus construiria suas instalações. A cessão foi comunicada ao Conselho Universitário em 14 de dezembro de 2005: "Sr. Reitor comunicou que no dia 07/12 houve solenidade, na Prefeitura de Diadema, de cessão de terreno, com 300 mil m2 para instalação do Campus, localizado à beira da represa." (Ata Conselho Universitário 14/12/05).

Logo em seguida foi promulgada a lei municipal $n^{\circ} 2.463$, de 20 de dezembro (DIADEMA, 2005), que autorizava o convênio de cooperação técnica entre a prefeitura e a Unifesp para a promoção de cursos de graduação, pós-graduação, e técnicos sequenciais em Diadema. Em outras palavras: criava as permissões de que a prefeitura necessitaria para apoiar a instalação do campus.

A universidade prontamente organizou-se para elaborar um projeto arquitetônico para a construção da sede do campus no Sítio Morungaba e lançou o edital em abril de 2006, de acordo com registro em ata. No entanto, o projeto nunca se concretizou.

[O Reitor]Comunicou que, no dia 10/04, foi lançado Edital de Concurso, com inscrições até o dia 24/04, de elaboração do Projeto Arquitetônico para sede do Campus de Diadema, com 400 mil m2 de área de preservação ambiental, as margens da represa Billings. (Ata Conselho Universitário de 12/04/2006). 
Enquanto a universidade elaborava os projetos para o novo campus, a prefeitura cedeu o uso de um conjunto de edifícios no bairro do Eldorado, que viria a se tornar a unidade José de Filippi, próxima ao Sítio Morungaba. As atividades do campus se iniciaram em março de 2007, com os cursos farmácia/bioquímica, ciências biológicas - bacharelado, química e engenharia química.

Em agosto de 2007, o terreno da unidade José de Filippi foi doado pela prefeitura à União conforme consta em ata do Conselho Universitário:

[O reitor] Informou que esteve no dia 16/08 [de 2007], em cerimônia com o Prefeito de Diadema, ocasião em que foi assinada escritura de doação do prédio, situado em terreno de $20.000 \mathrm{~m} 2$ local em que está funcionando a Unifesp. (Ata Conselho Universitário de 12/09/07).

José de Filippi Jr. lembra que a intenção era aproveitar a oportunidade para investir em uma região social e ambientalmente frágil de Diadema. Acreditava-se que a presença da universidade pudesse dinamizar o bairro e induzir o desenvolvimento urbano, conforme o ex-prefeito comenta:

O sítio Morungaba, lá no Eldorado, (...) é uma das regiões mais pobres de Diadema e uma das regiões mais desafiadoras para se ter uma ocupação urbana. Eu não tenho dúvida que uma universidade que se preze, que lute pelo meio ambiente, que tenha pesquisadores na área, que estudam química, biologia, seria uma das formas mais adequadas de se ocupar, dentro dos índices que a legislação permitia, a borda de uma represa" (...) Eu acho que a universidade, o papel dela é (...) permitir um desenvolvimento. Era uma região que os estudantes poderiam morar, então desenvolver o Eldorado. $\mathrm{O}$ transporte vai melhorar, os serviços, restaurantes, a universidade vai levar esse tipo de melhoria urbana. Queria que os professores, muitos deles, inclusive, passassem a morar lá, no Eldorado, gostaria que isso também acontecesse, agora são mais de 200 professores, então isso significa trazer para a cidade inteligência. (Entrevista. José de Filippi Junior, 19/07/2018).

Essa ideia de José de Filippi Júnior, de promover o desenvolvimento urbano através da instalação de um equipamento público, é bastante difundida. Por exemplo, Pinheiro (2007) a repete em seu trabalho:

No ano de 2006, este bairro [Eldorado] recebeu um equipamento de grande porte que tende a dinamizar todo o entorno, a Universidade Federal de São Paulo, que já está em funcionamento, além do futuro campus que será construído [Sítio Morungaba], e cujo projeto já foi escolhido por concurso. Assim, um equipamento deste porte, cujo impacto se estende ao bairro e também ao município todo, requer investimentos públicos que adequem a área a esta nova estrutura. Deste modo, os investimentos em infraestrutura nesta área serão intensificados. (PINHEIRO, 2007, p. 101).

Filippi complementa, ainda, que sua expectativa era de que a universidade fizesse com que "os estudantes e os professores passem a ter uma convivência com a cidade e com suas ins- 
tituições, a Igreja, os sindicados, o poder constituído, o poder local, o executivo e o legislativo." (Entrevista. José de Filippi Junior, 19/07/2018).

Contudo, como se detalhará adiante, não se confirma a ideia de que um equipamento público possa, por si só e automaticamente, induzir transformações no seu entorno. Também não se confirmou a hipótese de investimentos em infraestrutura motivados pela instalação do campus. Evidentemente que o bairro passou por mudanças, mas as relações que o campus estabelece com seu entorno são bastante frágeis.

Outra expectativa que aparece na bibliografia sobre a expansão das universidades e também naquela sobre a relação entre desenvolvimento e universidades, é que a presença da universidade elevaria os níveis de capacitação da população local, ou seja, que os moradores do município e da região seriam capacitados pela universidade e isso promoveria uma importante transformação social, que induziria a outras mudanças.

Entretanto, o próprio ex-prefeito comenta sua frustração ao ver, já no primeiro vestibular, que isso não se tornaria verdadeiro. Como o vestibular é nacional, os moradores de Diadema concorrem com estudantes de todo o país. Na seção 2.1 destacou-se o quadro da educação em Diadema que, apesar de ter evoluído ao longo das últimas décadas e garantir amplo acesso de crianças e adolescentes ao ensino fundamental e médio, ainda tem baixo desempenho nas avaliações nacionais. Como consequência, o vestibular demonstrou que os moradores de Diadema teriam dificuldades para acessar a universidade. Segundo Filippi Jr.,

o primeiro vestibular que teve aqui, de 200 alunos acho que teve só dois de Diadema. Isso é um pouco o outro lado. E é assim mesmo, uma universidade pública tem o seu processo de seleção aberto para o país inteiro (Entrevista. José de Filippi Junior, 19/07/2018).

De acordo com Filippi Jr., a diretoria do campus, ciente disso, criou os cursos de licenciatura, no final de 2007. A intenção era capacitar os professores para trabalharem na rede pública da região para elevar a qualidade do ensino em Diadema e região. Em 2011, inclusive, foi cogitada a proposta de uma escola de aplicação, complementar, mas que não vingou ${ }^{25}$.

os nossos alunos saem em muita desvantagem para disputar uma vaga em uma universidade pública como é a Unifesp. Então a gente percebeu isso (...) Esse curso... [a licenciatura] a professora Virgínia foi muito rápida, com apoio do reitor da época e da nossa equipe da secretaria de educação de propor cursos dessa área de licenciatura. Quer dizer, a Unifesp ajudar a formação de professores nas áreas de física, química, que são decisivas para que pudesse formar melhor os professores, ou formar

25 Essa escola de Aplicação se confunde com uma proposta de Escola Técnica, conforme se detalhará no capítulo 3. 
até professores que não existiam, e uma formação boa, para que eles pudessem ser reprodutores desse bom conhecimento nas escolas estaduais, nas escolas de Diadema para preparar a juventude para ingressar na universidade. (Entrevista. José de Filippi Junior, 19/07/2018).

A aprovação dos cursos de licenciatura ocorreu juntamente à da adesão da Unifesp ao Reuni. Isso significava que a universidade entraria em um novo patamar de expansão. Como apresentado no capítulo 1, a universidade teve que elaborar um plano para expandir-se e sua opção foi tanto de criar novos campi quanto de ampliar os campi existentes, dentre eles o de Diadema, que logo aprovou a criação de novos cursos: Ciências Ambientais, Licenciatura Plena em Ciências, Química Industrial, Farmácia e Bioquímica.

Entretanto, a expansão acadêmica do campus aconteceu em descompasso com a expansão física. O projeto para o Sítio Morungaba avançou e estancou na aprovação dos órgãos ambientais, até ser abandonado pela universidade, em 2014. Para o Entrevistado 4, um grande volume de trabalho havia sido empenhado na execução daquele projeto. De acordo com ele, foram realizadas diversas reuniões em que se formulou o programa de necessidades dos laboratórios. Além disso, a urgência de se finalizar o projeto demandou trabalho durante o natal e ano novo de 2014.

A reforma dos edifícios doados pela prefeitura também tardou a ficar pronto e já em 2008 o campus enfrentou sua primeira crise, com uma greve de estudantes que exigiam da reitoria melhorias na infraestrutura do campus.

Ainda em 2008, a universidade, juntamente ao MEC, iniciou a busca por novos edifícios e a mitigação do problema aconteceu ao longo dos anos A alternativa encontrada pelo campus foi a fragmentação. A prefeitura de Diadema cedeu o uso de parte do edifício onde está alojada a Fundação Florestan Fernandes, e lá o campus abrigou salas de aula, restaurante universitário e a biblioteca. Além desse, foram alugados dois imóveis, um à rua Antônio Doll, ao lado do Terminal Diadema, e outro à rua Manoel da Nóbrega, ambos próximos ao centro do município.

A mais importante aquisição aconteceu em 2009 e foi concretizada em dezembro daquele ano, quando a universidade assinou o termo de posse de três lotes desapropriados da massa falida da indústria Conforja.

A deficiência de infraestrutura prosseguiu e motivou uma mobilização para a que o campus encontrasse novos edifícios para se expandir. Os anos de 2013 e 2014 foram de buscas por 
novos edifícios, com a ajuda da prefeitura de Diadema, e também em São Paulo, no bairro do Ipiranga, e em São Caetano (Ata Congregação do campus Diadema de 01/11/2013).

De acordo com Alexandrino, existia na busca de imóveis em outros municípios uma vontade de que o campus deixasse Diadema porque não teria dado as condições para a consolidação do campus. A pergunta que se fazia à época era: "vamos ficar aqui em Diadema, uma cidade que não nos deu condições? Esse discurso existia em muitos colegas.” (Entrevista. João Alexandrino. 14/05/2018).

Os imóveis apresentados pela prefeitura de Diadema, assim como os avaliados em São Caetano e no Ipiranga não se viabilizaram. Portanto, o campus ficou sem o espaço necessário para abrigar suas atividades. Em virtude disso, em 2014 o campus optou pela redução do número de vagas disponíveis para o vestibular por questões de ocupação e segurança dos laboratórios didáticos, atrelada a um compromisso de se reformarem espaços para que abrigassem novos laboratórios, como consta em ata de congregação do campus:

\begin{abstract}
Aprovação de redução de vagas para ingressante: foi discutido o assunto lamentandose a necessidade de redução de vagas, comentou-se problemas relacionados à retenção, à evasão e baixo números de formandos, à lotação de laboratórios e à segurança nestes. Lembrou-se que a medida é temporária. A direção acadêmica comentou que o campus e a reitoria trabalharão para a normalização da situação, reforçando se tratar de medida emergencial. (...) lembrou que terão de ser realizadas ações para que o campus consiga se readequar para voltar ao número original de oferta de vagas, comentando a necessidade de no mínimo mais três laboratórios. (Ata Congregação do campus Diadema de 10/10/2014).
\end{abstract}

Dois meses depois, em dezembro de 2014, o campus aprovou o seu Plano Diretor de Infraestrutura $\left(\mathrm{PDInfra}^{26}\right)$, que orientaria a expansão do campus pelos anos seguintes. Este plano foi elaborado como uma alternativa à busca por edifícios na região, assim como de ordenar o desenvolvimento do campus.

A principal decisão contida no PDInfra era concentrar os investimentos futuros na unidade José de Alencar, no centro, nos terrenos desapropriados da antiga indústria Conforja. Desta forma, contrariava-se a intenção original do ex-prefeito, José de Filippi Junior, de promover o desenvolvimento do bairro do Eldorado; naquele bairro, segundo o plano, a universidade manteria uma unidade de extensão.

26 Plano Diretor de Infraestrutura do Campus Diadema - PDInfra - disponível em https://www.unifesp.br/ reitoria/proplan/pdinfra/pdinfra-titulo/campus-diadema/plano-diretor-documentacao-completa $>$. Acesso em $18 / 12 / 2018$ 
A justificativa técnica para tanto foi que as experimentações realizadas pelos laboratórios são incompatíveis com uma área de proteção aos mananciais, como consta em ata de congregação abaixo. Com a crise econômica e política que o país atravessa, essa ideia vem sendo rediscutida.

Já foi apontado pela empresa IDOM que a Unidade José de Filippi, por estar em uma área de proteção ambiental, não deve ser utilizada para fins de experimentação, que resultam na geração de resíduos químicos (solventes orgânicos, resíduos tóxicos como $\mathrm{Hg}, \mathrm{Cd}, \mathrm{Pb}$, entre outros -, resíduos secos, como sílica e alumina de colunas cromatográficas) e biológicos. (Documento anexo à Ata da Congregação do campus Diadema de 18/12/2014).

Além disso, o PDInfra prevê a construção de 6 edifícios em duas fases. A "fase 1" é composta pelos seguintes 3 edifícios: de Acesso, destinado a salas de aula e atividades acadêmicas; Bloco Norte, para laboratórios de pesquisa e ensino; e Biblioteca/Auditório. A "fase 2" seria a construção de outros três edifícios: bloco sul, também de laboratórios; de conexão, que teria salas de aulas; e edifício de extensão, para as atividades homônimas.

Assim, todas as atividades de pesquisa e ensino estariam concentradas no centro de Diadema, os imóveis alugados seriam devolvidos, assim como o cedido pela prefeitura. Hoje, apenas o edifício de sala de aulas, está em construção, e a previsão de conclusão é para o final de 2019. Os demais não têm previsão de início.

As condições de infraestrutura insuficientes para abrigar as atividades foram a principal motivação para uma crise perene no campus desde seu primeiro ano, quando os estudantes organizaram uma greve. Ao longo do tempo, em diversos momentos e de formas distintas, a questão tornava à pauta e é, até hoje, um fator que dificulta a consolidação do campus.

Por exemplo, em 2014, o Ministério Público foi acionado através de uma denúncia anônima acerca das condições do campus (Ata Congregação do Campus Diadema, de 03/062014) e os docentes locados na unidade do bairro do Eldorado entregaram uma carta à congregação manifestando as más condições de infraestrutura daquela unidade, além de problemas de segurança:

[Uma professora] leu carta de docentes que estão alocados na Unidade José de Filippi/ Eldorado, manifestando indignação quanto a problemas de infraestrutura e de pessoal desde o início de seu uso, prejudicando as atividades acadêmicas bem como colocando em risco frequentadores do local. Aborda ainda a questão da insegurança/ violência no bairro culminando, inclusive, com interrupção de serviços de entrega dos Correios. (Ata Congregação do campus Diadema de 07/02/14). 
Um segundo documento similar foi encaminhado em 2016, mas, dessa vez, já não se solicitava mais a correção dos problemas de infraestrutura senão a alocação de todos os laboratórios de pesquisa na unidade do centro de Diadema. Entre os argumentos apresentados estavam a dificuldade para atrair estudantes para a pesquisa quando o laboratório estava na unidade José de Filippi, dificuldades para realizar refeições fora do campus e pela inexistência de lanchonetes próximas e, a mais explícita, solicitava a completa extinção daquela unidade: "[uma docente] comentou que era favorável à extinção da unidade citada, comentando que no passado os docentes manifestaram a preferência por um espaço reduzido a ficarem na Unidade José de Filippi." (Ata Congregação do campus Diadema de 01/09/16).

Embora não esteja registrado em nenhum documento, tampouco tenha havido menções explícitas nas enquetes aplicadas entre docentes e técnicos, nem durante as entrevistas, há uma ideia geral contrária à unidade José de Filippi derivada não só de sua condição de infraestrutura, mas do contexto urbano em que se insere, próximo a algumas favelas urbanizadas e não urbanizadas.

O auge da crise para o campus aconteceu em 2015 quando houve a renúncia da diretoria. Para João Alexandrino, a crise toda vem justamente por não ter havido uma solução para os problemas de infraestrutura, que significava, também, a falta de uma orientação para o desenvolvimento do campus. Para ele,

o que explica a crise, assim, em termos macro, é que houve uma incapacidade de or-
ganizar a instituição para que esses 260 docentes estivessem inseridos tanto naquilo o
que é o dia-a-dia, como qual é o caminho. Isso perdeu-se. E ai, veio um certo caos e
ai veio uma crise. E na crise todo mundo perdeu o caminho. O seu caminho individual
não, porque isso todo docente universitário sabe qual é o seu, ele tem uma carreira e
quer chegar lá. Agora o caminho institucional perdeu-se.” (Entrevista. João Alexan-
drino. 14/05/2018).

Para o Entrevistado 4, os problemas de infraestrutura são a causa de um sentimento coletivo de frustração, porque muitos professores não tiveram condições de realizar suas pesquisas.

Enquanto isso, o ex-prefeito, José de Filippi Júnior, foi sucedido por Mário Reali, também do Partido dos Trabalhadores, e houve manutenção das relações com a universidade e algumas parcerias novas foram firmadas.

Em 2009, prefeitura e universidade firmaram um convênio para a instalação a implementação do Sistema Universidade Aberta do Brasil - UAB - que é um programa que 


\begin{abstract}
busca ampliar e interiorizar a oferta de cursos e programas de educação superior, por meio da educação a distância. A prioridade é oferecer formação inicial a professores em efetivo exercício na educação básica pública, porém ainda sem graduação, além de formação continuada àqueles já graduados. Também pretende ofertar cursos a dirigentes, gestores e outros profissionais da educação básica da rede pública. Outro objetivo do programa é reduzir as desigualdades na oferta de ensino superior e desenvolver um amplo sistema nacional de educação superior a distância. Há polos de apoio para o desenvolvimento de atividades pedagógicas presenciais, em que os alunos entram em contato com tutores e professores e têm acesso a biblioteca e laboratórios de informática, biologia, química e física. (Disponível em $<$ http://portal.mec.gov.br/politicade-educacao-inclusiva?id=12265>. Acesso em 11/10/2018).
\end{abstract}

Esta parceria foi registrada com a lei municipal $N^{0} 2.940$, de 21 de dezembro de 2009 (DIADEMA, 2009) e, desde então, o campus Diadema é um dos polos de apoio ao funcionamento da UAB.

Já em 2010, foram estabelecidas parcerias com a Secretaria de Saúde para estágio obrigatório na área de atenção farmacêutica e convênio de gestão compartilhada do Laboratório Clínico do Quarteirão da Saúde, conforme consta em ata:

A notícia mais importante foi a assinatura do convênio com a Secretaria da Saúde da Prefeitura de Diadema, para estágio obrigatório na área de atenção farmacêutica. Disse que foi assinado também convênio de gestão compartilhada do Laboratório Clínico do quarteirão da saúde. (Ata Conselho Universitário de 10/03/10).

Este convênio foi aprovado pela lei municipal no 2.973, de 30 de abril de 2010, e modificado pela lei municipal $\mathrm{n}^{\circ} 3.166$, de 17 de novembro de 2011, quando passou a se referir a todos os cursos de graduação e pós-graduação que a Unifesp possuísse. Também é desta época a formulação de um projeto de escola de Engenharia, em parceria com o Ciesp, a prefeitura e o SESI/SENAI, mas não logrou êxito até então.

Entretanto, o fim da gestão Mario Reali significou uma ruptura política para o campus. A gestão seguinte teria dado menos apoio à universidade, sobretudo por atritos na relação entre a prefeitura e a universidade. O Entrevistado 4 lembra que esses atritos foram motivados pela manutenção e uso do edifício da sede da Fundação Florestan Fernandes, parcialmente cedido para a universidade, e por problemas no convênio com a secretaria de saúde.

Para o ex-diretor acadêmico do campus, João Alexandrino, essa ruptura foi motivada por problemas no convênio da secretaria de saúde com a universidade, que levou ao seu rompimento. Para ele, essa ruptura significou o abandono ou o atraso de muitas parcerias e projetos de pesquisa e extensão porque o campus fechou-se, inclusive por sua crise interna. 
Havia um convênio muito importante para a Unifesp e para a cidade que era um convênio na área de saúde, e não envolvia só Diadema, envolvia São Paulo. Era um projeto de residências de alunos de medicina que iam para os hospitais da cidade. Houve problemas e uma das primeiras coisas que a secretaria de saúde da nova gestão da cidade fez foi cortar com a Unifesp. Isso gerou uma muito má imagem da Unifesp perante a prefeitura, essa nova gestão. Então houve, ali, um corte com a Unifesp, e eu diria que durante dois ou três anos, a Unifesp se esqueceu da cidade porque nós passamos por uma crise aqui dentro. (Entrevista. João Alexandrino. 14/05/2018).

Ainda de acordo com Alexandrino, o campus mudou sua postura e em 2016 voltou a procurar a prefeitura para estreitar laços. Entretanto, ele relata que houve dificuldades motivadas pela divisão de secretarias entre partidos distintos e com outras preocupações, assim como uma câmera de vereadores que não acreditava mais na potencial relação do campus com o município:

\footnotetext{
Nós não conseguíamos conversar, dialogar com as secretarias. Cada secretaria tem a sua agenda, tem suas prioridades, às vezes são de partidos distintos, não conversam com outras secretarias. (...) Nós tínhamos alguns vereadores que nos apoiaram mas outros que eram muito críticos relativamente à universidade ter vindo para cá e, na visão deles, ela não ter contribuído como ela poderia ter contribuído para a cidade. (Entrevista. João Alexandrino. 14/05/2018).
}

A recuperação de laços da universidade com a prefeitura veio a acontecer, de fato, no ano seguinte, 2017, quando campus e prefeitura se reuniram no gabinete da desta para apresentar algumas demandas, sobretudo de reforma da cobertura do edifício da sede da Fundação Florestan Fernandes. De acordo com Alexandrino:

Só a partir dessa reunião, que o prefeito declarou que nós tínhamos que ter a porta aberta. E nomeou a secretária de comunicação como agente articuladora, além do vice -prefeito. A partir daí, eu julgo que nós começamos a ter as portas abertas. (Entrevista. João Alexandrino. 14/05/2018).

Desde então, a relação se estreitou principalmente através da revisão do Plano Diretor de Diadema, que se tornou uma importante ferramenta para reunião dos diversos agentes promotores do desenvolvimento urbano, com participação da universidade. Da articulação deles, inclusive, nasceram outros grupos como o "Diadema, Cidade Inteligente", que pretende nortear o planejamento urbano pelos conceitos de "cidades inteligentes"27.

Também foi muito favorável para a reaproximação entre prefeitura e campus Diadema a apresentação do projeto de um Atlas Ambiental, projeto coordenado pela Professora Ana Luisa Bittencourt. A ideia geral do atlas converge para o plano "Diadema, Cidade Inteligente", ambos 
apresentados em 2018, uma vez que o agrupamento de dados e informações sobre o município é central no conceito de cidades inteligentes.

Essa retomada de relações ocorreu não apenas com a prefeitura. De forma geral, aproximadamente desde 2016, o campus tem assumido novas posturas perante aquilo que o envolve, sobretudo ao compreender que havia sido perdida a janela de oportunidades ${ }^{28}$. Para Alexandrino, foi no momento que se decidiu lidar com os edifícios disponíveis, que a crise passou a se dissolver e as atenções puderam voltar-se para os arredores do campus:

No contexto da crise, que entretanto o Brasil começa a passar, nós percebemos que o
financiamento público, principalmente do MEC, para o nosso plano diretor do cam-
pus, já não ia ser nem rápido, nem fácil, nem garantido. Então houve, numa primeira
fase, uma tentativa de apresentar o projeto no Consórcio Intermunicipal do ABC. Nós
pedimos que o prefeito nos organizasse uma reunião do consórcio. Fomos lá apresen-
tar o projeto. Mas, em 2016 , Diadema sai do consórcio. Então também não conse-
guimos por aí, que isso se concretizasse. E é quando nós, de certa forma, desistimos
um pouco da ideia de pensar que essa construção dos nossos edifícios iria ser rápida.
Eu acho que nós mantivemos uma esperança até 2016 , de que essa consolidação iria
ser rápida, e que a nossa solução estava ali. O campus, durante muitos anos, pensou:
"A nossa solução está nos prédios". E eu acho que todo mundo colocou o seu pensa-
mento nisso, esquecemos um pouco os projetos com o nosso entorno. Porque isso era
para depois. Eu acho que em 2016 nós resolvemos essa questão meio psicológica de
dizer assim: "Não". (...) Então, nós vamos ter que cuidar do que nós temos. E fazer
o máximo possível com o que nós temos. Não vamos ter mais. Nem mais espaço, e
recursos nós vamos ter que ir buscá-los, vamos ter que construir parcerias. A partir
dessa visão que eu acho que a Unifesp, em Diadema, renasceu. E nós passamos a ten-
tar cativar os colegas a irem lá no baú e ressuscitar essas ideias dos projetos. Porque o
que estava acontecendo aqui não é criar nada do novo, é, sim, criar um contexto, um
ambiente em que as pessoas se sintam motivadas a agir ((Entrevista. João Alexandri-
no. 14/05/2018).

Nesse sentido, o Brasil atravessava um período de crescimento econômico com grande investimento nas universidades federais e em pesquisa. Havia, portanto, a disposição política e recursos orçamentários para fazer crescerem as universidades, sobretudo através do Reuni.

Todavia, quando o campus finalmente havia corrigido sua rota, elaborado o PDInfra e iniciado os projetos executivos, os cenários econômico e político mudaram. A crise econômica trouxe uma série de cortes para a educação e a pesquisa que, somados à crise política pela qual o país atravessa desde 2014, culminaram em um cenário de imprevisibilidade da execução dos planos da universidade para o campus Diadema.

Atualmente, o panorama da educação é o inverso do que era em 2007, quando o campus foi inaugurado. A aprovação da PEC 55, em 2016, congelou os gastos públicos, obrigando-os 28 Maricato (2014), fala em "janela de oportunidade" para aquele período de tempo em que há um alinhamento de fatores que permitiram a elaboração de propostas para as políticas públicas urbanas, o que não se restringe a elas. 
a permanecer no volume executado no ano anterior, corrigido no máximo ao valor da inflação, durante um período de 20 anos. Apesar disso, a universidade não abandonou seu projeto e segue atrás de outras fontes de financiamento para os edifícios que não tiveram obras iniciadas, seja via outros ministérios (como o MCTI, para o bloco norte, de laboratórios), seja via Lei Rouanet (para a biblioteca), ou ainda através de emendas parlamentares.

Além da questão da perda da janela de oportunidades e de infraestrutura, o Entrevistado 4 acrescenta que houve a superação de uma ideia de segregação do campus perante a cidade. Para ele, os primeiros anos foram marcados por um choque, em que docentes, técnicos e estudantes, se viam em meio a um contexto urbano marcado pela pobreza e pela violência. O percurso até a unidade do Eldorado se faz por favelas não urbanizadas na divisa entre Diadema e São Paulo, o que teria causado muito espanto para a comunidade acadêmica. Além disso, eram muitos os casos de assaltos e furtos não só no entorno do campus, mas no município em geral ${ }^{29}$.

Para o Entrevistado 4, foi apenas com a superação dessa ideia por uma outra, de interação com os arredores, que o campus passou a estabelecer mais conexões:

No começo também tinha isso, (...) o pessoal se horrorizava com a pobreza, com a violência, como se o problema da violência fosse Diadema, fosse a localidade, e não um problema social. Então, tinha sempre aquela discussão de levantar muros contra a pobreza, contra a diferença, e querer a polícia dentro do campus. Até que nós falamos: 'Não! Em vez de levantar muros, vamos interagir com essa comunidade'. E aí foi um processo (...) foi criando uma percepção da cidade que já não é mais de susto ou de medo, e já começa a se enxergar como próximos ou semelhantes à população de Diadema, passíveis de interação. (Entrevista. Entrevistado 4. 09/10/2018).

Logo, foi em consequência dessa mudança de postura perante o seu entorno, da realização do PDInfra e dos projetos executivos tanto quanto da aceitação de que o contexto econômico e político nacional mudou, assim como da consolidação acadêmica dos cursos, que o campus passou a intensificar as suas relações com escolas, empresas, indústrias, órgãos públicos, representações sociais e de classe.

Passados 11 anos da instalação do campus, as deficiências de infraestrutura ainda não foram superadas, mas, de acordo com Alexandrino, a crise interna foi contornada e o campus passou a vislumbrar um potencial futuro, inclusive com a retomada da confiança de outros agentes, principalmente a prefeitura, e do estreitamento de laços. Para ele, hoje o campus tem

29 Nesse sentido, Caldeira (2000), adverte sobre a conexão que se faz no imaginário coletivo entre pobreza, favelas e criminalidade. Dessa noção deriva a sensação de insegurança que afastou o campus do seu entorno imediato. 
em vista um futuro promissor com cada vez mais participação e importância para o desenvolvimento regional e urbano:

Eu diria que o que nós recuperamos, nos últimos dois anos, foi esse caminho. Ele ainda não está documentado, ele ainda não é claro para todos. (...) E diria, também, que a primeira imagem do que ele é, de forma muito geral, apareceu nessa reunião [com a prefeitura em 2017, como comentado anteriormente]. Que é essa tríade, educação, desenvolvimento econômico, associado a tecnologia de vanguarda e plural e a questão da sustentabilidade ligada a uma cidade inteligente e altamente tecnológica. (...) Então, se nós conseguirmos um projeto que alavanque o município para um outro patamar de desenvolvimento, acho que Diadema será um exemplo não só local, mas também mundial. (...) E Diadema (que significa jóia) talvez no futuro, sei lá, daqui 5, 6 anos, possa ser considerada uma joia, tanto na Unifesp, quanto no mundo. (Entrevista. João Alexandrino. 14/05/2018).

\subsection{Ensino}

O campus Diadema tem foco em 6 áreas do conhecimento, além da licenciatura em ciências cujas descrições seguem abaixo, tal qual mencionadas pelo próprio campus em seu site.

\section{Ciências biológicas:}

(...) pretende formar um profissional capacitado em ciências moleculares, celulares e fisiológicas, genética e evolução, botânica, zoologia e ecologia, capaz de entender as complexas relações entre os organismos biológicos e o meio ambiente e consciente da necessidade de atuar com qualidade e responsabilidade em prol da conservação e manejo da biodiversidade e, com isso, contribuir para o desenvolvimento sustentável. (Retirado de $<$ https://www.unifesp.br/campus/dia/ensino/graduacao/ciencias-biologicas $>$. Acesso em 21/11/2018);

\section{Ciências Ambientais}

(...) constitui uma abordagem inter e multidisciplinar que visa o estudo integrado das ciências naturais (física, biologia, geologia e química) e das ciências sociais (ética, antropologia, economia e política) para aprender como a Terra funciona e como lidar com os problemas ambientais, visando a remediação de áreas contaminadas, a conservação e o desenvolvimento sustentável. (retirado de < https://www.unifesp.br/campus/ dia/ensino/graduacao/ciencias-ambientais $>$. Acesso em 21/11/2018);

\section{Química}

[formação distribuída] nas áreas de conhecimento de Ciências Moleculares, Ciências Físicas e Matemáticas, Ciências Biológicas, Ciências Ambientais e Análises Químicas. (...) o profissional químico formado em nosso curso poderá se dedicar à produção e manejo de matéria prima, de produtos manufaturados, controle de qualidade do produto acabado, uso desses produtos em processos secundários e, ainda participar do planejamento de ações que permitam prevenir, monitorar e remediar a contaminação ambiental resultante dos processos mencionados. (retirado de $<\mathrm{https}$ ://www.unifesp. br/campus/dia/ensino/graduacao/quimica. . . Acesso em 21/11/2018); 
Química industrial:

O Químico Industrial é o profissional que formula produtos e supervisiona unidades industriais de fabricação de produtos químicos, petroquímicos, plásticos, alimentos, etc. Pode atuar também em laboratórios de indústrias de transformação e na área comercial de produtos químicos e derivados, além de exercer qualquer atividade dentro da área da Química, menos aquelas que envolvam planejamento, projetos e montagem de equipamentos e instalações industriais. (retirado de $<$ https://www.unifesp.br/campus/dia/ensino/graduacao/quimica-industrial $>$. Acesso em 21/11/2018);

\section{Engenharia Química}

O Curso de Engenharia Química da Unifesp tem como objetivo a formação de um profissional com capacidade analítica, com sólida formação em engenharia e capacidade de interagir criativamente com as interfaces da Matemática, Física, Biologia e Química, sendo capaz de utilizar ferramentas clássicas e modernas para solucionar problemas, além de compreender as relações entre os sistemas produtivos, o ambiente e o homem que o integra. (retirado de <https:/www.unifesp.br/campus/dia/ensino/ graduacao/engenharia-quimica $>$. Acesso em 21/11/2018);

Farmácia:

(...) tem como objetivo central a formação de um profissional capacitado a atuar na área das análises clínicas e toxicológicas, com enfoque especial na toxicologia ambiental e humana, em todos os setores da cadeia produtiva de medicamentos, cosméticos, alimentos e insumos farmacêuticos (indústria farmacêutica, de cosméticos e de alimentos), na farmácia pública e hospitalar e no Sistema Único de Saúde (SUS), apto a desenvolver ações de prevenção, promoção, proteção e reabilitação da saúde, tanto em nível individual quanto coletivo. (retirado de $<$ https:/www.unifesp.br/campus/ dia/ensino/graduacao/farmacia-e-bioquimica $>$. acesso em 21/11/2018);

Dessas descrições, destacam-se duas características importantes. A primeira delas é a correlação direta com o contexto urbano e regional. As abordagens mais comuns nas pesquisas sobre a relação entre expansão universitária e desenvolvimento urbano e regional apontam, em geral, para uma ligação direta entre os cursos e a economia local e regional. Isso ocorre no caso de Diadema, uma vez que parte dos cursos está diretamente voltada para as indústrias química, farmacêutica e metalúrgica, ou seja, as de mais pujança da região,.

Parte dessa conexão entre a universidade e as indústrias, é compreendida, na literatura, como a formação de quadros técnicos capacitados para atender às demandas de mão-de-obra qualificada da indústria. Todavia, há indícios de um descompasso entre a área de formação dos egressos do campus Diadema e o trabalho que exercem. Um trabalho de conclusão de curso de engenharia química avaliou a ocupação dos estudantes formados pelo campus nesta área espe- 
cífica e constatou que apenas $28 \%$ dos egressos trabalhavam na área em que foram diplomados, enquanto a média nacional seria de 42\% (GIARDINI e SANCHES, 2016).

Por outro lado, uma aproximação maior permite observar a segunda característica marcante, que é a abrangência e a inter-relação entre cursos. Nesse sentido, se enfatiza a descrição dada às ciências ambientais, que envolve ética, antropologia, economia e política, bem como a relação com as ciências humanas na abordagem da formação de técnicos e pesquisadores em um campus dedicado às ciências naturais. Isso significa que há uma gama de possibilidades de interpretações do contexto urbano e regional para além da formação específica orientada para a indústria. Dessa forma, há linhas de pesquisa sobre saúde, meio ambiente (que inclui o espaço urbano), trabalho, economia, ecologia, evolução e sociedade.

Assim, há no campus um grande potencial de incidência no processo de desenvolvimento urbano e regional, tanto pelos conhecimentos reunidos (docentes) quanto pelos produzidos (pesquisa) e também pelos transmitidos (graduação); tanto pela ligação direta com o escopo das indústrias quanto pela formulação de políticas públicas em diversos setores. A questão passa a ser, portanto, a necessidade de articulações e arranjos políticos que permitam ao campus ser efetivamente em um agente.

Uma outra aproximação do escopo do campus com o contexto urbano e regional é o destaque que as apresentações das áreas de química e ciências ambientais dão ao tema das contaminações ambientais e suas remediações. Como já exposto, Diadema carrega consigo um passivo ambiental fruto da industrialização e da formação do espaço urbano. Desse processo surge outro problema, o da contaminação da água, sobretudo da represa Billings, advindo da ocupação irregular de mananciais e da ausência de infraestrutura durante boa parte das décadas (que não é exclusividade de Diadema senão comum à RMSP).

Para completar o quadro de cursos oferecidos pelo campus Diadema há o curso de Licenciatura Plena em Ciências - LPC - (biologia, química, física e matemática). O ex-prefeito de Diadema, José de Filippi Jr., em entrevista, relembrou que o surgimento do curso de licenciatura foi um movimento rápido da Unifesp ao perceber que havia, e ainda há, um descolamento entre a formação escolar de Diadema e região e o acesso à universidade pública.

Essa percepção foi concomitante ao decreto $\mathrm{n}^{\circ}$ 6.755, de 29 de janeiro de 2009 , que tinha entre seus objetivos "promover a melhoria da qualidade da educação básica pública" e 
"apoiar a oferta e a expansão de cursos de formação inicial e continuada a profissionais do magistério pelas instituições públicas de educação superior;” (BRASIL, 2009).

Desta forma, houve suporte legal e recursos financeiros para que em 2010 o campus Diadema lançasse seu curso de licenciatura para formar docentes para a rede pública local e regional, com o intuito de promover a melhoria da qualidade do ensino.

Apesar disso, não houve uma diretriz clara para a criação do curso. O Entrevistado 4 relaciona isso à inexistência de uma escola de aplicação ou de institutos específicos das ciências em que seriam formados os novos professores para dar um norte ao curso recém-criado. O professor José Alves lembra que isso trouxe a necessidade de se criar o curso a partir da realidade, levando em consideração o que a universidade dispunha, assim como as necessidades locais. Desta forma, docentes do curso foram conhecer Diadema e as escolas públicas. Alves relata que houve um intenso esforço de mapeamento e estabelecimento de contato durante alguns anos, tanto para que o campus passasse a reconhecer as escolas quanto para que as escolas soubessem da existência e importância da universidade.

Entretanto, estudos realizados sobre a oferta do curso de licenciatura sinalizam um desprendimento entre a proposta e a realidade já na graduação, ao apontar para uma distinção entre o propósito do curso e a motivação dos estudantes. Em Silva et al (2013) há um dado importante: a taxa de evasão chegava a 55\%. Entre as motivações investigadas estavam o desinteresse prévio pelo curso (como o acesso é dado pelo Sisu, o estudante pode escolher pelos cursos de acordo com o seu desempenho no Enem), o que motivava a mudança para outros cursos ou universidades e, inclusive, mudança para a rede privada através do ProUni. O Entrevistado 4 fez um relato dessa situação da seguinte forma:

\footnotetext{
Nós descobrimos uma coisa muito interessante, que tem a ver com o Sisu: $55 \%$ dos alunos que entravam no curso não queriam fazer o curso. Por que entravam? Porque tiveram uma nota no Enem e eles queriam fazer qualquer outra coisa, Engenharia, Medicina... Ganhavam uma nota no Enem e olhavam no Sisu onde eles poderiam caber. E o que eles cabiam? A nota deles cabia no curso deles e para não perder a vaga, marcavam lá e vinham. Mas era isso. Então, não eram alunos que queriam virar professores. (Entrevista. Entrevistado 4. 09/10/2018).
}

A esse respeito, uma outra questão importante foi comentada por Alves. Para ele, apesar de que o curso de licenciatura tenha o maior número de estudantes do campus e que todos eles tenham que fazer estágio obrigatório nas escolas públicas, aquelas mais afastadas do centro 
ainda não têm a atenção da universidade como as mais centrais, geralmente por motivos de segurança e por orientação das próprias diretorias:

A gente também só vai para colégio central, importante dizer isso, porque é muito perigoso a gente colocar um aluno até 11 horas da noite para fazer estágio onde só tem uma condução... as diretoras ficam preocupadas, elas nos avisam: "Cuidado, não deixem, melhor vocês irem para tais e tais colégios. (Entrevista. Prof. Dr. Jose Alves da Silva. 22/11/2018).

Por fim, em conversas informais com docentes da licenciatura, a fragilidade social e a forma de acesso ao curso apareceram como um outro aspecto da relação do curso de licenciatura com o contexto urbano e regional. O fato observado pelos docentes é que os estudantes provêm de diversas regiões da RMSP, às vezes até de fora dela e, em geral, com poucos recursos financeiros (muitos, inclusive, se revezam entre estudo e trabalho em tempo integral). Desta forma, associado a uma metrópole com graves problemas de mobilidade, o acesso ao campus se tornara inviável a uma parte dos estudantes. Para o Entrevistado 4, isso representava um sofrimento para parte dos estudantes:

Sofrimento que eu digo é que muitas vezes o aluno não vinha para a aula porque não
tinha dinheiro para o ônibus. Vinha, não tinha como comer, às vezes o restaurante
estava fechado... Às vezes ele morava longe. Aquele aluno que saiu da Unifesp e foi
para uma universidade paga porque era mais barato. E o aluno dizia: "Professor, para
mim é mais barato pagar duzentos reais numa faculdade do lado da minha casa, que
eu saio do trabalho, vou para lá e de lá vou para casa, do que sair de Guarulhos, vir
para Diadema, de Diadema volta para lá" (...) Então, foi uma coisa que nós fomos
descobrindo, embora a universidade fosse gratuita, a entrada pelo Sisu, não eram os
moradores locais que vinham, e isso significava uma vulnerabilidade muito grande,
porque o pessoal tinha que vir de fora e permanecer ali. E como uma pessoa vem e
permanece ali? Com que dinheiro? Com que condições sociais? (Entevista. Entrevis-
tado 4. $09 / 10 / 2018$ ).

Um ponto que merece destaque é aquele para o qual chamou a atenção José Alves, de que estudantes da licenciatura já estão compondo as diretorias de ensino e podem agregar a elas a visão que acumularam de suas experiências de vida com o aprendizado da universidade.

Além desses trabalhos, há três últimos que estão interrompidos, mas que são de grande importância. Trata-se da implantação de uma escola técnica, uma escola de engenharia e uma escola de aplicação. Nas entrevistas realizadas e na leitura das atas de congregação do campus, as ideias se confundem, mas são propostas distintas.

O Entrevistado 4 lembra que havia a previsão de uma escola técnica desde o estabelecimento do campus, mas que não havia registros na universidade. De fato, não se localizou nenhuma referência nas atas do Conselho Universitário, apenas na legislação de Diadema. A lei 
municipal $\mathrm{n}^{\mathrm{o}} 2.463$, de 20 de dezembro de 2005, que autoriza a celebração do convênio entre o município e a universidade, traz em seu artigo primeiro a seguinte redação:

Fica o Poder Executivo autorizado a celebrar convenio com a Universidade Federal de São Paulo, - UNIFESP, visando o desenvolvimento de ações conjuntas destinadas à promoção de cursos de graduação, pós-graduação e técnicos (sequenciais), no Município de Diadema. (DIADEMA, 2005. Destaque do autor).

Essa ideia é semelhante a uma proposta que foi resgatada na entrevista com o Entrevistado 1, para quem uma escola técnica era essencial para o município, por seu caráter eminente de qualificar mão-de-obra para a indústria de Diadema e região. Já para o ex-diretor, João Alexandrino, a proposta seria, na verdade, de uma escola de engenharia. Todavia, elas não chegaram a ser formalizadas.

Por outro lado, nas atas de congregação do campus foi encontrada uma menção a uma escola técnica, que depois foi chamada de Escola de Aplicação. Essa teria um outro caráter pois, sendo ligada ao curso de licenciatura, focaria na educação e na formação de professores. O Entrevistado 4 relembra, em entrevista, que o projeto da Escola de Aplicação chegou a ser estruturado pelo campus e apresentado à prefeitura, mas também não evoluiu.

Nenhuma das três propostas, inclusive o da Escola de Aplicação, teve sucesso até o momento. Entretanto, elas são de extrema importância para o município e para a região. Uma escola técnica teria, fundamentalmente, ligação direta com as indústrias, com o "chão da fábrica", com a produção - capacitação de mão-de-obra. Já a Escola de Aplicação seria um contributo importante para as transformações sociais porque se relacionaria com a condição da qualidade da educação de Diadema e região.

\subsection{Pesquisa}

Para levantamento de colaborações do campus com os processos de desenvolvimento urbano e regional no que diz respeito à pesquisa e parcerias com agentes externos, foram realizadas entrevistas presenciais e por e-mail. Foram obtidas 19 respostas, das quais 8 foram negativas para estabelecimento de parcerias, sendo que há, dentre estas, 4 que afirmaram terem sido procurados por empresas, mas que não resultaram em parcerias. 
Entre os motivos listados estão a falta de infraestrutura do campus para desenvolver a pesquisa proposta, dificuldades no relacionamento entre empresas privadas e fundações de apoio à pesquisa, dificuldades no processo de estabelecimento dos convênios que levaram as empresas a desistir, alterações nos interesses e prioridades das empresas e, por fim, a crise econômica.

Das 18 respostas recebidas, 11 afirmaram ter estabelecido algum tipo de parceria que, de acordo com as entrevistas, foram informais, através de convênios ou de estudantes de pósgraduação com temas sugeridos pelas empresas em que trabalhavam. Em muitos casos não foi possível obter o detalhamento sobre a pesquisa; em dois casos particulares foi mencionado haver sigilo nessa informação. Chama a atenção o predomínio de parcerias com empresas com sede em São Paulo ou no exterior, sem representações em Diadema ou no ABC.

Além das respostas cedidas pelos docentes, também foram levantadas propostas de pesquisas e parcerias que partiram de indústrias ou industriais, que também foram consideradas, apesar de não terem resultado em trabalhos conjuntos efetivos até o momento. Apesar disso, são importantes como demonstração das possibilidades que existem e das dificuldades que há no processo de aproximar universidade e indústrias.

A seguir, estão listadas as parcerias estabelecidas com empresas ou indústrias.

- Empresa norte-americana do setor sucro-alcooleiro;

- Empresa alemã de química e farmacêutica;

- Empresa petrolífera anglo-holandesa para avaliar os efeitos do etanol em gasolina na contaminação de águas subterrâneas a partir da experiência brasileira. Houve participação de empresa de consultoria, cujo papel era avaliar a possibilidade de remediação por oxidação química em uma área contaminada. As empresas financiaram bolsas e custos de pesquisa, equipes de campo e material de consumo. O campus Diadema realizou a pesquisa, emitiu relatório e os estudantes realizaram planejamento dos ensaios, análise de dados e acompanharam os trabalhos de campo. A CETESB colaborou com a pesquisa através da disponibilização de relatórios;

- Empresa alemã com fábrica em São Bernardo do Campo, que procurou o campus a fim de desenvolver um refrigerador magnético para suas instalações. Durante a operação das máquinas o ambiente atinge temperaturas muito elevadas, que são nocivas para seus funcionários e, por isso, acarretam diversos problemas de saúde e processos trabalhistas. Segundo o 
professor Ricardo Galdino, as negociações foram interrompidas quando a crise econômica do país se acentuou e não foram mais retomadas;

- Empresa nacional que desenvolve tecnologias em química e biotecnologia, com sede em São Paulo;

- Empresa nacional do ramo de tratamento de efluentes, com sede em São Paulo, realizou parceria em caráter informal para estudos de contaminação de solo e de água e possibilidades de remediações;

- Empresa nacional de química e petroquímica com sede em São Paulo;

- Empresas da região do ABC procuraram o campus Diadema para desenvolver o projeto de um motor que pudesse gerar energia elétrica a partir do calor eliminado pelas chaminés. De acordo com o professor Ricardo Galdino, a mesma pesquisa foi sugerida por vereadores, à época, para gerar energia elétrica para favelas onde o fornecimento ainda não tinha sido disponibilizado e a rede viabilizada. Ambos foram interrompidos ainda na fase preliminar;

- Empresas de metalurgia da região do ABC recorreram ao campus Diadema para participar do desenvolvimento uma impressora 3d para metais. Uma impressora semelhante já existe na Unicamp, porém com viés medicinal. Esta serviria à indústria metalúrgica, o que teria grande impacto para a região;

- Foi apresentada uma proposta para o desenvolvimento de uma impressora 3D para a construção civil, com participação do campus Diadema com pesquisa sobre materiais e motores, e colaboração do Sesi, Senai e empresas da região. O projeto não evoluiu porque não teria encontrado interesse das empresas da região.

Cabe considerar que as impressoras 3D têm se popularizado pelo mundo, e ao redor de todo o globo apontam para uma transformação da produção em diversos segmentos. O advento da impressão 3D significa uma nova etapa da robotização e da informática, com possibilidades de produções mais baratas, rápidas, em plantas industriais mais adensadas e maior apuro técnico.

Nesse sentido, o desenvolvimento de uma impressora 3D para metais em Diadema, com parceria entre universidade e indústrias parece central e com enorme importância para o desenvolvimento regional, uma vez que grande parte das industrias locais são do ramo da metalurgia. 
Isso significaria romper com um modelo histórico de importação de tecnologia, enquanto o país, e a região mais especificamente, acompanhariam a transformação produtiva em curso no mundo, ao invés de ficar a reboque dela. Também significa que a indústria da região não ficaria desfalcada em um ambiente de competição internacional.

O avanço das tecnologias e as alterações da produção podem fazer com que as indústrias do $\mathrm{ABCD}$ se tornem menos eficientes e eficazes (se não atualizadas) e, por isso, percam na competição internacional, até mesmo se tornem obsoletas, ou ainda fiquem dependentes do empenho de capitais para atualizar seu maquinário.

Além disso, cabe considerar que o desenvolvimento de tais tecnologias depende da conjunção de outras tantas. Pode-se afirmar que haverá transformações para trás e para frente. Para frente são as transformações que as impressoras podem provocar e que acontecerão mesmo em casos de importação da tecnologia. Sobre a construção civil, pode-se imaginar que, quando implementadas, implicarão em alterações na forma de se pensar e projetar edifícios, o que modificará os cursos de arquitetura e engenharia, os canteiros de obra e a habitação (enquanto produto, principalmente porque as previsões são de que se reduza drasticamente o tempo de construção), entre outros.

Para trás, serão todas as tecnologias que precisam ser desenvolvidas para tornar a impressora 3D uma realidade, ou seja, são anteriores às impressoras em si, como novos materiais, novos motores, novo programas, etc. Portanto, desenvolver essa tecnologia localmente ao invés de importá-la significa reunir um certo grupo de saberes e de pessoas que possam torná-la realidade e desenvolver outras tecnologias.

Além das parcerias listadas acima, procurou-se parcerias entre o curso de farmácia e industrias da região porque esse é um setor de destaque e, inclusive, há um Polo de Cosméticos em Diadema. Todavia, não foram localizadas parcerias envolvendo pesquisa e o setor farmacêutico. Apenas uma menção foi feita a um Simpósio realizado no campus, o I Sci Farma ${ }^{30}$, em novembro de 2017.

Esse Simpósio teve como pauta a elaboração de novos fármacos e medicamentos, bem como suas aplicações terapêuticas. Além disso, discutiu-se sobre o tratamento ao câncer e seus

30 O I Sci Farma foi um simpósio do curso de farmácia realizado por docentes e estudantes do campus Diadema em novembro de 2017. Foi dividido em 4 sessões temáticas que abordaram assuntos relacionados ao desenvolvimento de novos fármacos e medicamentos, além de suas aplicações terapêuticas. 
desafios, doenças inflamatórias e o envelhecimento, além de doenças infecciosas e negligenciadas (esta última atinge, sobretudo, a parcela mais vulnerável da sociedade).

O Simpósio foi apoiado por 11 empresas privadas de Guarulhos, Sorocaba, São Paulo (Barra Funda, Ipiranga e Socorro), São José dos Pinhais, Estados Unidos, Holanda e Reuno Unido. Apenas uma das empresas tem sede ou filial em Diadema. Suas colaborações foram prestadas na forma de serviços, como o fornecimento de materiais e de coffee-break.

Segundo a Entrevistada 5, o maior interesse das empresas participantes era divulgar suas marcas a potenciais consumidores de seus produtos, docentes e estudantes do curso de farmácia.

Já entre os órgãos públicos, foram mais expressivas e recorrentes as citações de parcerias com outras universidades, a prefeitura de Diadema (e secretarias específicas), a CETESB e a SABESP.

A CETESB foi citada em quatro respostas sobre parcerias, algumas já em andamento e outras ainda em elaboração com pesquisadores do campus, em geral para prospecção e de contaminantes emergentes no meio aquoso que devam ser monitorados.

Um dos núcleos do campus, chamado de NESPEQUI - Núcleo de Especiação química - possui equipamentos capazes de identificar espécies químicas em baixíssimas concentrações, mas que podem ser nocivas. Desta forma, seria possível identificar contaminantes em rios, represas, entre outros, e fazer o monitoramento.

Uma outra parceria em elaboração entre campus e CETESB é para monitoramento da qualidade das águas no Estado de São Paulo. E uma terceira proposta, que envolve a Faculdade de Saúde Pública da USP, é a construção de modelos que permitam projetar cenários de vulnerabilidade ambiental e de saúde pública. O professor Décio Semensatto Junior detalha a proposta da seguinte forma:

O objetivo mútuo é desenvolver com maior profundidade as análises de dados sobre a qualidade da água que são gerados pela rede de monitoramento da companhia. A responsabilidade da companhia é dar acesso às informações que são coletadas pela sua rede e prestar apoio nas análises. A da universidade é o de desenvolver estudos que integrem os dados da Cetesb àqueles produzidos por diversos grupos de pesquisa, auxiliando em uma melhor visão estratégica e panorâmica da companhia sobre as políticas públicas que são desenvolvidas para a conservação ambiental no Estado de São Paulo. Além dessa iniciativa, nosso grupo está preparando um projeto temático a ser submetido à Fapesp, em conjunto com outros pesquisadores do campus, da Faculdade de Saúde Pública (USP) e com a Cetesb. O objetivo é construir modelos integrados que prevejam cenários futuros de vulnerabilidade ambiental e de saúde pública (doen- 
ças hidroveiculadas) frente às mudanças climáticas em curso, na bacia hidrográfica da Represa Guarapiranga. (Entrevista. Decio Semensato Junior. 28/06/2018).

Houve, também, duas parcerias com a Secretaria de Saúde. Uma delas trata de um convênio entre a Unifesp e a prefeitura de Diadema, que existiu entre 2002 e 2013, mas não envolvia o campus. A Unifesp coordenava um dos hospitais da região e estudantes de medicina ${ }^{31}$ e cursos correlatos faziam estágio no hospital e clínicas municipais. O convênio foi encerrado após atritos entre universidade e Prefeitura, quando da mudança da gestão municipal.

A outra parceria com a Secretaria de Saúde foi informal e estabelecida para projeto de extensão e coleta de dados para pesquisa. A parceria durou 4 anos e foi encerrada com a troca de gestão da secretaria.

Já com o Ministério Público Federal - MPF - a Unifesp estabeleceu um convênio que propõe o uso dos laboratórios de pesquisa disponíveis na universidade para a realização de pesquisas e laudos do ministério a fim de compreender a gravidade de acidentes ambientais analisados pelo órgão e ter maior precisão no estabelecimento de multas às empresas infratoras. $\mathrm{O}$ campus Diadema participara, sobretudo, com as áreas de Ciências Ambientais e Química, com análises de casos de acidentes com contaminações de solo, água e ar. Em contrapartida, o MPF se comprometeu a repassar à universidade parcelas dos recursos recolhidos via TAC - Termos de Ajustamento de Conduta para estruturação física, parque de equipamentos e capacitação institucional.

Por sua vez, a prefeitura de Diadema envolveu-se com os trabalhos de pesquisa do campus Diadema através da criação de um Atlas ambiental, organizado pela professora Ana Luisa Bittencourt, inspirado em um projeto semelhante realizado em Porto Alegre. Esse atlas foi realizado na década de 90 a partir de um convênio entre a prefeitura daquele município e a Universidade Federal do Rio Grande do Sul.

A proposta para Diadema é ter um diagnóstico do município em relação ao meio físico, espaço urbano e sociedade, com vistas a abastecer de informações as políticas públicas que nortearão o desenvolvimento do município. Assim, o objetivo geral é reunir as informações que possam explicar as dinâmicas e qualidades do sistema natural, construído, humano, social e político da região, cumprindo a função social da universidade pública em prol do município, como explica Bittencourt:

31 Os cursos da área de biomédicas são ministrados no campus São Paulo, outrora Escola Paulista de Medicina. 


\begin{abstract}
A finalidade do projeto é expressar o papel social da universidade pública para a comunidade que a acolhe, no caso, Diadema; conjugar o espírito científico e o poder público na busca de resultados significativos para a sociedade, no caso é entender toda essa questão ambiental e evolução da cidade e as condições que as pessoas vivem aqui, como essas condições podem ser melhoradas. Disponibilizar o acesso às informações que permitam mapear as características do meio ambiente natural, urbano e social de Diadema; possibilitar expressar resultados de ações conjuntas entre a municipalidade e a comunidade científica, tecnológica e demais profissionais engajados no projeto. (Entrevista. Ana Luísa Bittencourt. 30/10/2018).
\end{abstract}

Os dados a serem reunidos e/ou levantados serão organizados em quatro grandes grupos temáticos, dentro dos quais estarão assuntos subdivididos, a saber: meio físico (geologia, solos, recursos hídricos, fauna e flora, biodiversidade e atmosfera); meio urbano (evolução do espaço urbano a partir de uma série histórica, solos urbanos, áreas de risco, resíduos, fontes poluidoras, saneamento e tratamento, saúde e meio ambiente); sociedade (educação, arte e cultura e etnologia); e gestão e políticas públicas.

O projeto está em seu primeiro ano de desenvolvimento, embora fosse um desejo antigo. Tardou para ser lançado pois houve a necessidade de se concentrarem esforços na consolidação dos cursos de graduação e pós-graduação, assim como do próprio campus. Segundo Bittencourt:

Depois de esses anos todos de implantação e atuação no curso, desenvolvimento do curso, a chegada de novos docentes, ampliação da área das ciências ambientais aqui no campus. (...) Era uma vontade consolidar a atuação das ciências ambientais aqui. (...) com esse tempo curto de existência que nós temos em Diadema, são 12 anos que existe o campus da Unifesp, agora que nós estamos expandindo determinados estudos. (Entrevista. Ana Luisa Bittencourt. 30/10/2018).

Destaca-se que a implementação e a consolidação do campus aparecem novamente como motivação para a restrição de trabalhos realizados com a comunidade externa à universidade.

Nesse sentido, há duas parcerias estabelecidas para o desenvolvimento do projeto, com o IBGE - Instituto Brasileiro de Geografia e Estatística - e a própria prefeitura de Diadema. A parceria com o IBGE ainda não está formalizada, mas se prevê tanto a cessão de dados que o Instituto possui, como apoio técnico ao desenvolvimento da pesquisa. Já a prefeitura de Diadema tem convênio de cooperação e colaborará com o projeto através da cessão de dados e informações, assim como da disponibilidade de técnicos das secretarias.

Além disso, o Atlas Ambiental se relacionará diretamente com o plano "Diadema: Cidade Inteligente", lançado também em 2018 pela prefeitura de Diadema. "Cidades Inteligentes" são definidas dentro do projeto do Atlas Ambiental como 
sistemas de pessoas interagindo, usando energia, materiais, serviços e financiamento para capitalizar o desenvolvimento econômico e a melhoria da qualidade de vida. De outra forma, cidades inteligentes correspondem ao uso de tecnologias de informação e comunicação para promover uma melhoria da qualidade de vida dos seus cidadãos, a um custo acessível, otimizando o uso dos recursos do planeta. (Entrevista. Ana Luisa Bittencourt. 30/10/2018).

O Atlas Ambiental serviria, então, como um grande depositório de dados e informações que subsidiarão o plano e as tomadas de decisões. Desta forma, será uma incidência direta do campus e de seus trabalhos de pesquisa e extensão na formulação de políticas públicas em Diadema. Para Bittencourt, há uma relação direta entre o conceito de cidades inteligentes e o atlas ambiental, pois ambos trabalham com banco de dados, tecnologia, informação, conhecimento, parcerias e redes.

Poli de Figueiredo (2018), em sua dissertação de mestrado intitulada "O discurso e a Prática da Smart City: perspectivas críticas e aproximações" argumenta que não há na literatura um conceito claro e definido sobre o que são cidades inteligentes, mas apresenta que estaríamos em uma terceira etapa dessa formulação, chamada de "minas de dados" que, como o próprio nome sugere, seria justamente a construção de bancos de dados associados às inovações de tecnologias da informação, com o objetivo de construir cidades socialmente mais justas e com gestões mais eficientes e eficazes. É nessa etapa que o discurso das cidades inteligentes passa a integrar as agendas públicas.

Todavia, o autor avalia que o discurso de cidades inteligentes não considera a forma específica de produção do espaço urbano no Brasil, pautado em conflitos de interesses e desigualdades sociais. Portanto, a aplicação do discurso das cidades inteligentes seria insuficiente para atingir seus objetivos, sobretudo de produção de cidades com igualdade de acesso aos bens públicos e homogeneização das localizações.

Apesar disso, o campus percebe esta parceria como um novo patamar nas relações com a prefeitura. Após alguns anos de atritos, estreitam-se os laços e se amplia a participação do campus na política municipal. Para o ex-diretor João Alexandrino

é uma grande utopia que está nascendo aqui. Eu sei que aqui eu sou um grande utópico, mas eu julgo que vários colegas estão começando a ser contagiados e quando eles veem o interesse da prefeitura, eles ficam mais contagiados. É extremamente importante você ter um órgão de gestão interessado na universidade, assim como, para esse órgão de gestão, eles perceberem que a universidade está interessada na cidade. Há uma simetria psicológica e emocional. Então eu estou vendo isso com grande esperança. (Entrevista. João Alexandrino. 14/05/2018). 
Já o ex-vice-diretor, Willian Hermoso, declarou ao site da Unifesp que “A parceria viabilizará tanto os planos em andamento quanto os futuros, permitindo maior inserção da universidade na cidade de Diadema e na região do grande ABC."32.

Destaca-se que através do plano "Diadema: cidade inteligente" o campus integrará uma rede de agentes que conta com o Instituto Mauá de Tecnologia, a Universidade Federal do ABC, a Universidade de São Paulo (USP), o Senai, além de empresas, indústrias e representações sociais de Diadema.

A partir da ideia de "cidades inteligentes", surgiu uma outra ideia, de um polo tecnológico gerido pela prefeitura, para interação entre universidades, escolas técnicas, empresas e indústrias, com capacitação profissional, de incubadora de empresas e até laboratórios compartilhados. Também deriva da ideia de cidade inteligente a proposta de um parque tecnológico no sítio Morungaba, hoje de propriedade da Unifesp, à margem da represa Billings. A proposta daria um uso para esse terreno que hoje encontra-se sem uso e sem perspectivas desde que a Unifesp optou por organizar seu campus no centro de Diadema.

O parque tecnológico seria aberto à população, gerido pela prefeitura de Diadema, e contaria com uma unidade avançada de pesquisa e extensão ligada à questão ambiental, sobretudo à represa Billings, além de ser, também, um centro de tecnologia e um observatório. Essa proposta, assim como do polo tecnológico, encontra-se em fase de formulação.

\subsection{Programas de Extensão e outros}

Dos programas de extensão realizados pelo campus Diadema, sobressaem-se os que seguem descritos abaixo por sua relação com o desenvolvimento urbano e regional. Nota-se a preponderância de trabalhos no âmbito do ensino, sobretudo com intuito de melhorias na qualidade do ensino público, que é uma fragilidade histórica de Diadema e toda a região do ABC.

Além disso, é nessa parte que surgiram as primeiras menções a movimentos sociais ou entidades de representação de classes, como os sindicatos. Até então, as relações mais mencionadas do campus eram com entidades patronais, empresas privadas, universidades, escolas técnicas e a prefeitura de Diadema.

32 Disponível em <http://www.unifesp.br/reitoria/dci/noticias-anteriores-dci/item/3305-unifesp-participa-do-lancamento-do-projeto-diadema-cidade-inteligente $>$. Acesso em 15/11/2018. 


\section{Projeto Integração Técnico-Científica da Unifesp}

Este projeto de extensão relaciona-se com empreendimentos solidários de Diadema e contou, na sua fase inicial, com um trabalho com os churrasqueiros e tapioqueiros ligados às suas respectivas associações dentro do programa de Economia Solidária da Prefeitura. O objetivo era permitir a melhoria dos serviços prestados por esses profissionais a partir de capacitação em temas como qualidade de serviços, marketing, microbiologia de alimentos, higiene e alimentos funcionais.

\section{Projeto Articulações}

O projeto Articulações é um programa que concilia pesquisa e extensão e se divide em outros 4 subprojetos: eventos, escolas, formação e cursinhos populares. O objetivo é promover a integração entre universidades, escolas, comunidade local, movimentos sociais, e poder público. Participam escolas públicas do ensino fundamental ao médio, escolas técnicas (Senai e CEFET-RJ), entidades representativas de classes e dos movimentos sociais (Sindicato dos Professores do Ensino Oficial do Estado de São Paulo/APEOESP-Diadema, Associação de Docentes da Unifesp/ADUnifesp, Emancipa, Rede Juventude Diadema Ativa, Espaço Cultural Coletivo 217, Associação de moradores Oeste, Associação de Moradores 18 de agosto e Sindicato dos Metalúrgicos) e a Secretaria Municipal de Educação de Diadema.

Cada um dos subprojetos tem seus objetivos específicos, voltados para pesquisa e para extensão. O subprojeto "eventos" tem como objetivo a realização de eventos colaborativos que valorizem e potencializem as relações entre os participantes do projeto, assim como o interesse em pesquisar sobre as articulações que se criam durante suas realizações.

Já o subprojeto "escolas" procura formar uma rede de professores-pesquisadores na educação básica a partir de cursos de acordo com demandas específicas das escolas. Enquanto tema de pesquisa, o que se pretende é estudar a progressão de carreira como uma forma de aproximar a escola da universidade, a fim de promover a construção de conhecimento a partir das próprias escolas.

Em paralelo, o subprojeto "formação" pretende desenvolver competências científicas com professores e gestores de escolas. A pesquisa procura levantar e compreender as necessidades escolares de formação dos docentes. 
Por último, o subprojeto "cursinhos" apoia diversas iniciativas de cursinhos populares em Diadema afim de que compartilhem recursos e conhecimentos. A pesquisa, nesse sentido, relaciona os cursinhos à identidade dos movimentos sociais que lhe dão suporte.

\section{Projeto Zero}

O "Projeto Zero" é um programa de ensino, pesquisa e extensão, que faz a integração dos cursos de Licenciatura Plena em Ciências (LPC) com a comunidade externa ao campus. De acordo com o site do programa, seus objetivos são:

Colaborar, a partir das pesquisas realizadas, com a construção curricular das Licenciaturas da Unifesp, em particular do Curso de Ciências - Licenciatura de Diadema; Integrar as ações de extensão e de pesquisa à formação dos graduandos a partir do princípio da práxis pedagógica; Integrar-se às políticas de formação continuada do MEC, com foco nas escolas de Diadema, visando a melhoria da formação dos professores da rede, assim como a ampliação e aprofundamento das pesquisas; Pesquisar os novos fenômenos presentes na licenciatura, buscando encontrar suas raízes e explicando-os a partir dos atuais e/ou de novos modelos teóricos; Pesquisar temas centrais da educação em ciências e matemática e da formação de professores de ciências e matemática; Apoiar a constituição do Programa de Pós-Graduação em Ensino de Ciências e Matemática do campus de Diadema; A constituição de um grupo de pesquisa de cunho sócio-histórico e abordagem dialético-crítica da CTSA, devidamente registrado no CNPq e na Unifesp, com docentes, Taes, graduandos e pós-graduandos, que apresente projetos às fontes de fomento e possa contribuir com a construção de novos modelos científicos; Estabelecer vínculos com outros grupos de pesquisa nacionais e internacionais. (retirado de <https://projetozero.com/objetivos.html $>$, acesso em 22/11/2018).

O Projeto Zero nasceu da indagação - oriunda da falta de uma orientação clara e objetiva para o curso - do que seria o curso de licenciatura e quais pesquisas poderiam ser desenvolvidas a partir da infraestrutura disponível no campus.

Hoje, o programa tem parcerias com uma escola estadual em Diadema, onde os estudantes de LPC desenvolvem trabalhos de extensão, assim como com o Centro Multidisciplinar para Investigação Biológica (CEMIB) da Unicamp, com colaboração em pesquisa. A intenção é que os estudantes desenvolvam um estágio propositivo, que possam participar ativamente da formação das escolas.

Todavia, segundo o Entrevistado 4, essa proposição encontra resistências políticas na organização das escolas públicas. Ele relata que muitas vezes, apesar do trabalho realizado com as escolas e das parcerias que se estabelecem com ela, há entraves que acabam barrando as ações por serem distintos do programa político-pedagógico. Outras vezes, a simples mudança 
de diretoria faz ruir a parceria que se havia estabelecido. Para ele, isso está relacionado às dificuldades relativas ao pacto federativo e as diferentes agendas dos três entes:

Tem uma instância, que é ligada ao governo federal, que vai atuar numa instância que é ligada no município ou numa instância ligada ao Estado. São três instâncias diferentes de poder que às vezes têm um certo conflito de cronograma, programas diferentes, propostas diferentes, concepções diferentes, paradigmas diferentes, autores diferentes. Não é uma coisa muito fácil você conseguir um certo sincronismo disso. (Entrevista. Entrevistado 4. 09/10/2018).

CIUNI - Cursinho Institucional Unifesp Diadema.

A partir da compreensão de que os estudantes de Diadema não têm acesso à universidade pública, sobretudo ao próprio campus Diadema, por desvantagens na competição com estudantes de outras regiões da metrópole e do país, um grupo de docentes criou o cursinho popular a fim de aumentar o ingresso dos jovens de Diadema nas universidades públicas.

Além disso, o projeto pedagógico busca ampliar a formação pré-universitária da população de Diadema a partir da superação das deficiências formativas do ensino fundamental ao médio, assim como capacitar os alunos para concursos e vagas de empregos.

Programas de Formação continuada de professores

Entre os programas de extensão desenvolvidos no campus Diadema, elencou-se dois que tem a semelhança da formação continuada de professores da rede pública. Um deles é o GEFOP - Grupo de Extensão em Formação de Professores - que tem como objetivo a formação continuada de professores a partir da prática docente, elaborar ações pedagógicas a partir da prática docente na rede pública, e da pesquisa sobre esta, de forma que o conhecimento produzido possa promover transformações no ensino.

O outro, PAPMEM - Programa de Aperfeiçoamento Para Professores de Matemática do Ensino Médio - que, como o próprio nome diz, oferece formação continuada para professores de matemática do ensino médio, oferece também outro programa de formação continuada de professores para o ensino de biologia.

Em conversas informais com docentes ligados ao GEFOP, constatou-se a mesma dificuldade que o Projeto Zero apontou para os estudantes de LPC: manter-se no curso. Embora a formação continuada tenha tempos de duração mais curtos que a graduação, nota-se, também, uma elevada evasão, motivada, sobretudo, pelas dificuldades de deslocamentos pela metrópole 
e a rotina de aulas e trabalho, uma vez que os cursos não são restritos a professores da rede de ensino de Diadema.

Programas de divulgação do campus Diadema

Dos programas de extensão, há três que se destacam pelo papel de tornar o campus Diadema conhecido pelos moradores de Diadema e região. Isso tem relação direta com a percepção geral de docentes e técnicos de que o campus não é conhecido. Não à toa: as placas de sinalização viária apontam apenas para a unidade José de Filippi, no bairro do Eldorado; a unidade José de Alencar, com entrada pela avenida Conceição é bastante tímida, com uma identificação pequena grafitada no muro, além de não ser possível ver nenhum edifício. Por outro lado, o maior edifício, o de laboratórios e administração (edifício de Vidro), fica afastado de áreas de grande circulação. As demais unidades não têm identificações e, além disso, apenas em 2017 uma linha de ônibus municipais passou a indicar "Unifesp" no seu letreiro, que vai do terminal Diadema ao bairro do Eldorado.

Para reverter esse cenário, o campus Diadema participou da Feira de Ciências, realizada em 2017, promovida pela prefeitura, que buscava apresentar trabalhos de ciências realizados pelas escolas municipais, assim como despertar o interesse da população pelas ciências, sobretudo as naturais.

Já em 2018 a prefeitura organizou a "Semana de Ciência e Tecnologia" com a intenção de promover o encontro e a interação entre as instituições que têm trabalhos correlatos, além de despertar o interesse pela ciência e pela tecnologia. Participaram do evento a Unifesp, SESI, SENAI, FATEC, ETEC JK, SEBRAE Grande ABC e SENAC.

No sentido inverso, de trazer para dentro de si a população de Diadema, estão eventos como o programa Universidade de Portas Abertas, que leva estudantes da rede pública para conhecer as instalações e os laboratórios de pesquisa e ensino do campus Diadema. Este programa tem um propósito especial que vai além de informar a existência do campus Diadema, pois preocupa-se em tornar de conhecimento dos estudantes das escolas públicas de Diadema, a existência de uma universidade pública e gratuita junto ao seu local de moradia e que é acessível através do Enem. 
Esse ponto do programa merece destaque porque se sabe que uma parte da população, sobretudo aquela que está na escola pública, não tem clara noção de que universidades públicas, como a Unifesp e a USP sejam gratuitas acessíveis via vestibular.

Nesse mesmo sentido, o "Encontro dos Surdos com a Ciência", promover acessibilidade à comunidade surda às ciências naturais para democratização do conhecimento e ensino acadêmico. Esse evento, inclusive, se insere no hall de trabalhos da Unifesp como um todo para atender as exigências legais de ampliar a acessibilidade ao ensino público. Inclusive, os docentes estão sendo orientados para prepararem aulas pessoas com deficiências, que em 2018 passaram a ter reserva de vagas.

\section{Outros programas:}

Além dos trabalhos de extensão existem outras iniciativas do campus para com a comunidade. Alguns deles são as Empresas Juniores que realizam, sobretudo, trabalhos de consultoria e capacitações para empresas e indústrias da região, sob orientação de docentes do campus. Entre elas estão as empresas Sustentare (ciências ambientais), Pharminder (farmácia), BUD (biologia) e EPEQ (engenharia química). Não se obteve contato com os representantes das empresas e as informações disponíveis pela internet são incompletas para maior detalhamento.

Além desses, a Unifesp, como um todo, está trabalhando na constituição de um Conselho Estratégico Universidade-Sociedade, órgão de caráter consultivo, que reunirá 60 membros entre sociedade civil e poder público para colaborar com o Conselho Universitário e ampliar as relações entre a universidade e a sociedade de forma geral.

O conselho será incumbido de propor e debater temas de interesse local, regional, nacional e internacional que orientem as ações da universidade; propor e debater políticas públicas e metodologias de ensino; colaborar com a avaliação dos estudantes formados pela Unifesp (o edital destaca neste ponto que esta avaliação analisará a inserção do estudante no mercado de tralho e sua atuação "em favor do desenvolvimento de uma sociedade justa, ética e sustentável”, que em partes permeia o presente estudo $)^{33}$.

Além desses, também são competências do conselho: avaliar políticas de acesso, inclusão e permanência; propor parcerias para desenvolvimento de inovações, assim como com 
movimentos socais, órgãos de classe e entidades da sociedade civil; propor parcerias público privadas para investimentos na universidade. Por fim, ao conselho será apresentada a prestação de contas anual.

Disso destaca-se que, dentro das competências com conselho, parte refere-se a questões de desenvolvimento regional e urbano, sobretudo no que tange às proposições de parcerias com agentes.

\section{5 - As relações com o espaço urbano}

Muitos trabalhos que avaliam a instalação de campi universitários da expansão ocorrida na primeira década deste século focam sobre os impactos produzidos sobre o espaço urbano, considerando que a introdução de um campus carrega consigo um contingente significativo de pessoas com padrões de consumo acima da média local e regional. O trabalho de Brüne (2015), por exemplo, chega a estimar os valores dispendidos pela comunidade acadêmica, que seriam uma injeção importante de recursos via consumo ou impostos aos municípios em questão, Palotina e Toledo, no Paraná.

Porém, como advertem Brüne (2015) e Baumgartner (2015), estes impactos tendem a ser mais significativos quanto menores as cidades. Além disso, também chamam a atenção de que estes impactos seriam esperados, de formas diferentes, para a instalação de qualquer outro equipamento, empresa ou o que fosse que tenha o mesmo porte. Assim, pensando-se sobre uma área metropolitana, é de se imaginar que esses impactos teriam menor importância.

Para avaliar isso, uma enquete foi realizada com docentes e técnicos, buscando levantar a relação que há entre estas questões e o espaço urbano. Esta enquete, disponível nos anexos deste estudo, permitiu mapear o local de moradia de técnicos e docentes, além de compreender como se dão e os tempos de deslocamentos entre residência e trabalho, a percepção sobre mudanças no entorno das unidades e alguns aspectos da relação das pessoas com o espaço urbano, sobretudo no município de Diadema.

As enquetes foram disponibilizadas para toda a comunidade acadêmica por e-mail com auxílio das diretorias administrativa e acadêmica do campus em duas oportunidades. Foram obtidas 21 respostas entre os técnicos, de um total de 110 alocados no campus (19\%), e 42 respostas entre os docentes, de um total de $250,(16,8 \%)$. 
Uma parte das questões era objetiva, por isso foram fechadas, como tempo de trabalho no campus, meio de transporte, entre outras. As demais questões foram abertas de forma que as respostas pudessem ser bastante variadas e trazer pistas de outras questões a serem avaliadas que ainda não tivessem sido imaginadas pelo pesquisador.

Por isso, com os formulários em mãos, as respostas foram organizadas e agrupadas. Isso permitiu transformá-las em estatísticas e também manter sua individualidade. Por exemplo, a questão sobre as motivações para não mudar a residência para Diadema apresentou uma grande variedade de respostas, mas muitas semelhantes em alguns aspectos, como motivos familiares ou não gostar do município. Para além disso, as respostas trouxeram elementos sobre a rotina além do trabalho que explicitavam um padrão de relação com o espaço urbano.

Com as respostas organizadas e separadas em grupos, se passou à interpretação dos dados à luz do que se considerou nos capítulos 1 e 2 , tanto daquilo o que se apresentou sobre a formação do espaço urbano em Diadema, quanto das questões levantadas em outras pesquisas semelhantes sobre a relação de universidades com o desenvolvimento urbano e regional.

A primeira questão levantada é sobre o local de moradia. Entre os docentes, constatou-se que $74 \%$ dos que responderam à enquete residem no município de São Paulo; $14 \%$ em São Bernardo, 7\% em Diadema, 2,5\% em Osasco e 2,5\% em Carapicuíba. Dos docentes que responderam que moram atualmente em Diadema, todos mudaram-se para o município quando começaram a trabalhar no campus da Unifesp; das três respostas, duas motivaram-se pela distância entre a residência anterior e o campus e uma pela intenção de se inserir no cotidiano do município. A síntese desses dados está na figura 53. Dentre os $26 \%$ de docentes que se mudaram, $19 \%$ optaram por Diadema e $81 \%$ por outros municípios.

Já os docentes que optaram por permanecer na mesma residência quando passaram a trabalhar no campus representam $62 \%$ do total de respostas. Entre esses, $11 \%$ afirmou não encontrar em Diadema uma opção de imóvel que lhes agradasse, $54 \%$ disse que não se mudou por motivos familiares, $38 \%$ citou a facilidade de transporte como um motivo para permanecer na mesma residência, 11\% afirmaram que já residiam fora de Diadema, mas próximo ao campus, e $31 \%$ citou como motivo para não se mudar algo relativo a Diadema, sobretudo a questão da violência, mas também questões ligadas a falta de lazer e cultura. Esses dados estão sintetizados na imagem 54. 
Figura 53 - Municípios de residência dos docentes do campus Diadema.

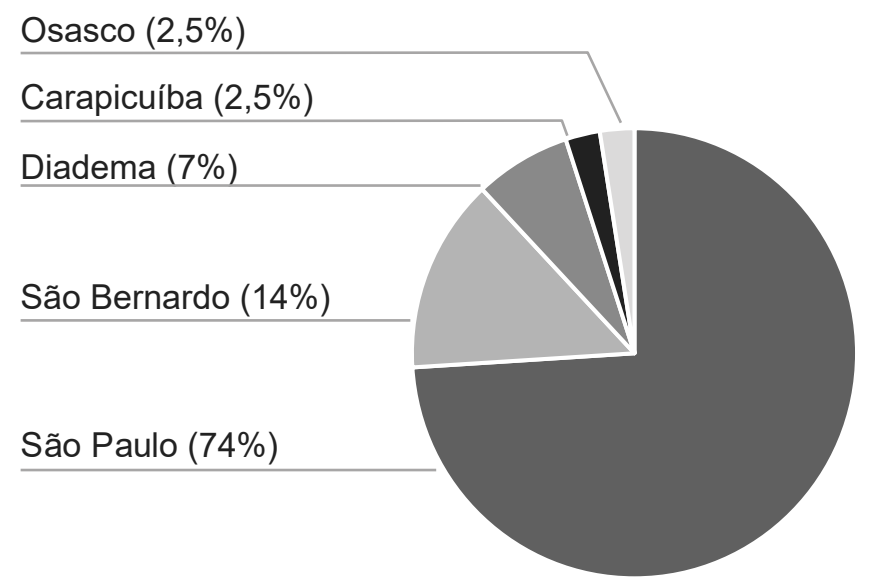

Fonte: Elaboração própria a partir de dados de enquetes

Figura 54 - Opção de docentes por mudarem ou não a residência para trabalhar no campus Diadema, motivos para não terem mudado e, entre os que se mudaram, se optaram por Diadema ou outros municípios.

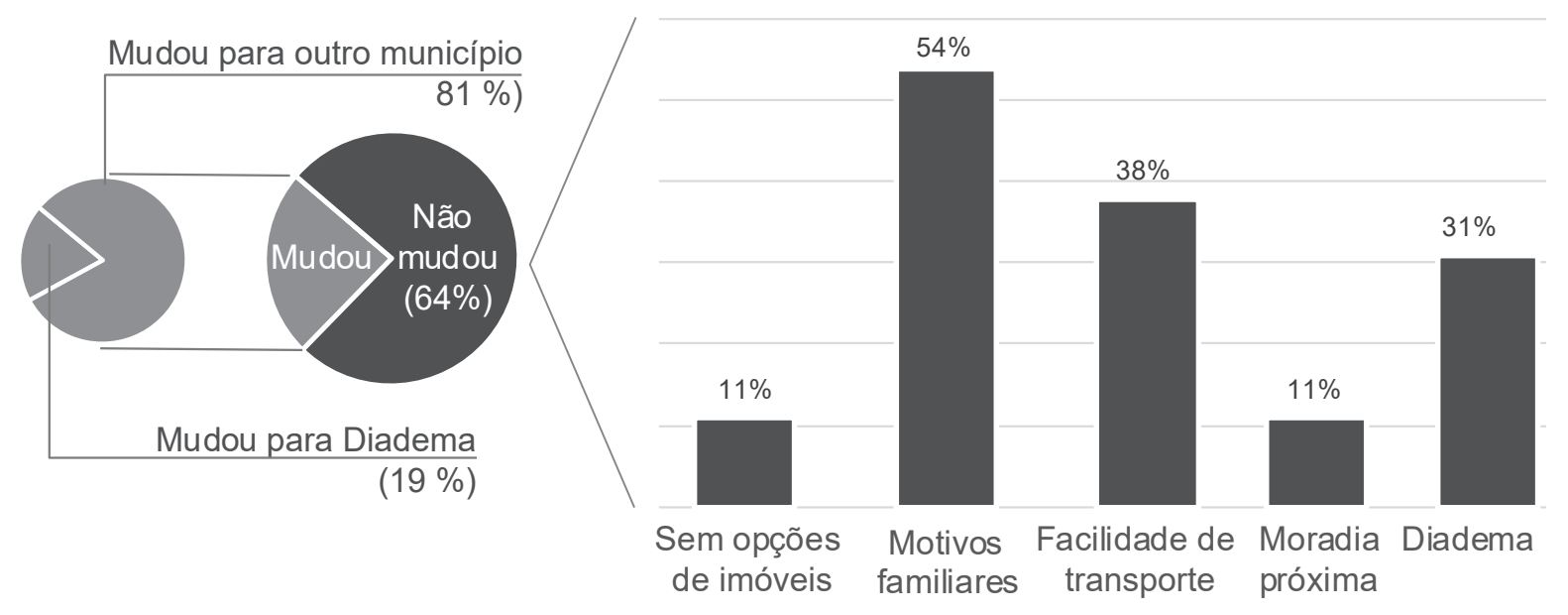

Fonte: Elaboração própria a partir de dados de enquetes.

Já entre os técnicos, São Paulo é o principal município de residência (33\%), mas ainda assim em bairros próximos ao campus. Diadema aparece em seguida, com 24\% das respostas; São Bernardo e Santo André aparecem com 14\% e 19\%, respectivamente, Osasco e Cubatão com 5\%, conforme imagem 55 .

O local de residência de docentes e técnicos tem distribuições bem distintas entre si; enquanto os docentes se concentram no quadrante sudoeste da metrópole (VILLAÇA, 1999), os técnicos moram mais próximos ao campus, como se pode observar nas imagens 56 e 57.

Considerando-se que os docentes têm rendimentos superiores à média da população da RMSP, não surpreende que suas moradias estejam distribuídas pelo território como estão, concentrados no quadrante sudoeste da metrópole (VILAÇA, 1998). Já entre os técnicos há 
uma variação grande de rendimentos, entre os níveis de carreira que vão desde o fundamental completo ao doutorado. Desta forma, justifica-se que estejam mais espalhados pela RMSP e que haja uma parcela maior entre os técnicos do que entre os docentes, que optaram por residir em Diadema.

Figura 55 - Municípios de residência dos docentes do campus Diadema.

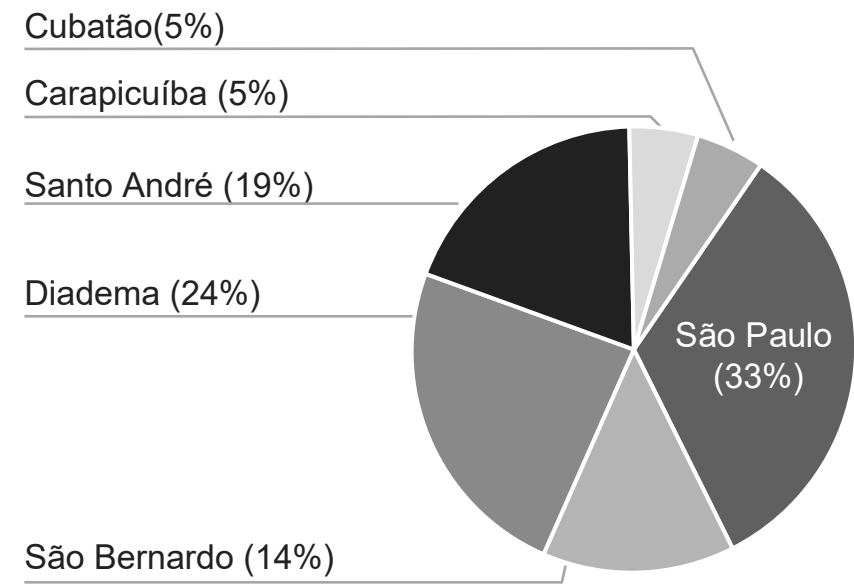

Fonte: Elaboração própria a partir de dados de enquetes.

Nota-se que também há uma diferença na forma de acesso de técnicos e docentes. Enquanto os docentes entram para ocupar uma vaga cuja pesquisa acontece em um campus e não em outro, os técnicos, no geral, encontram seus cargos à disposição em vários campi, salvo exceções para aqueles com atividades ligadas à pesquisa e à prática do ensino.

Para o campus Diadema houve duas formas de ingresso de técnicos: em alguns momentos foi possível que os candidatos especificassem para qual campus estavam concorrendo e noutros momentos não, sendo a lotação definida na hora da efetivação do cargo.

Ainda assim, de forma geral, o que se percebe é que, tanto técnicos quanto docentes, preferem não morar em Diadema. Entre os motivos apontados estão a residência da família e o desinteresse por Diadema. Mas dois fatores primordiais são o tempo e a facilidade de deslocamento.

Do total de técnicos, 76\% afirmou que não se mudou e os motivos apontados foram moradia próxima ao campus $(23 \%)$ e família (19\%). Questões relativas a Diadema apareceram em $10 \%$ das respostas, no geral com relação à atratividade do município, disponibilidade de programas culturais e segurança pública. Dos que se mudaram para trabalhar no campus $(24 \%$ do total), $60 \%$ escolheu um município que não Diadema para morar. Esses dados estão sintetizados na imagem 58 . 
Figura 56 - Distribuição das residências dos docentes do campus Diadema.

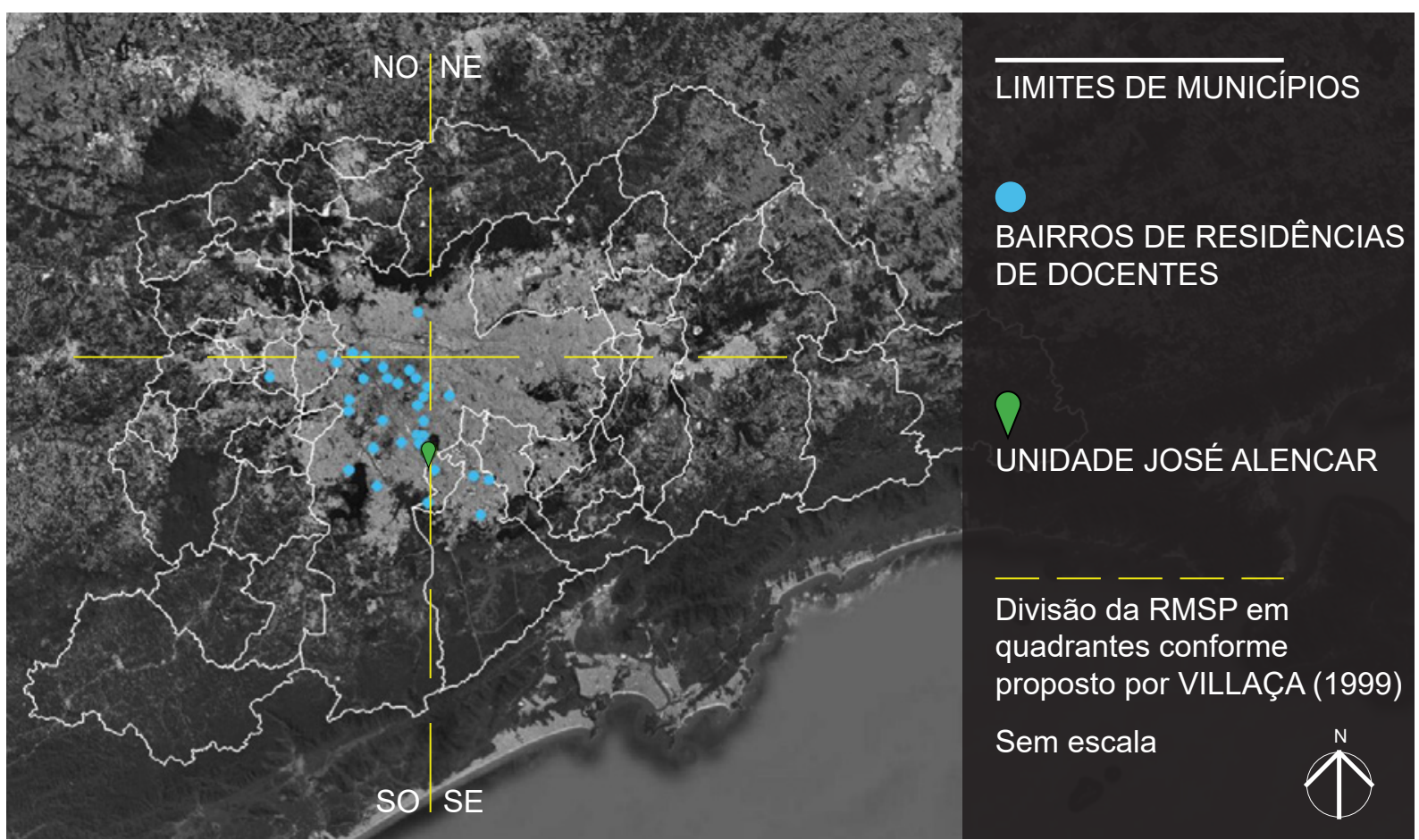

Fonte: Google Earth. Elaboração própria a partir de dados da enquete.

Figura 57 - Distribuição das residências dos técnicos do campus Diadema.

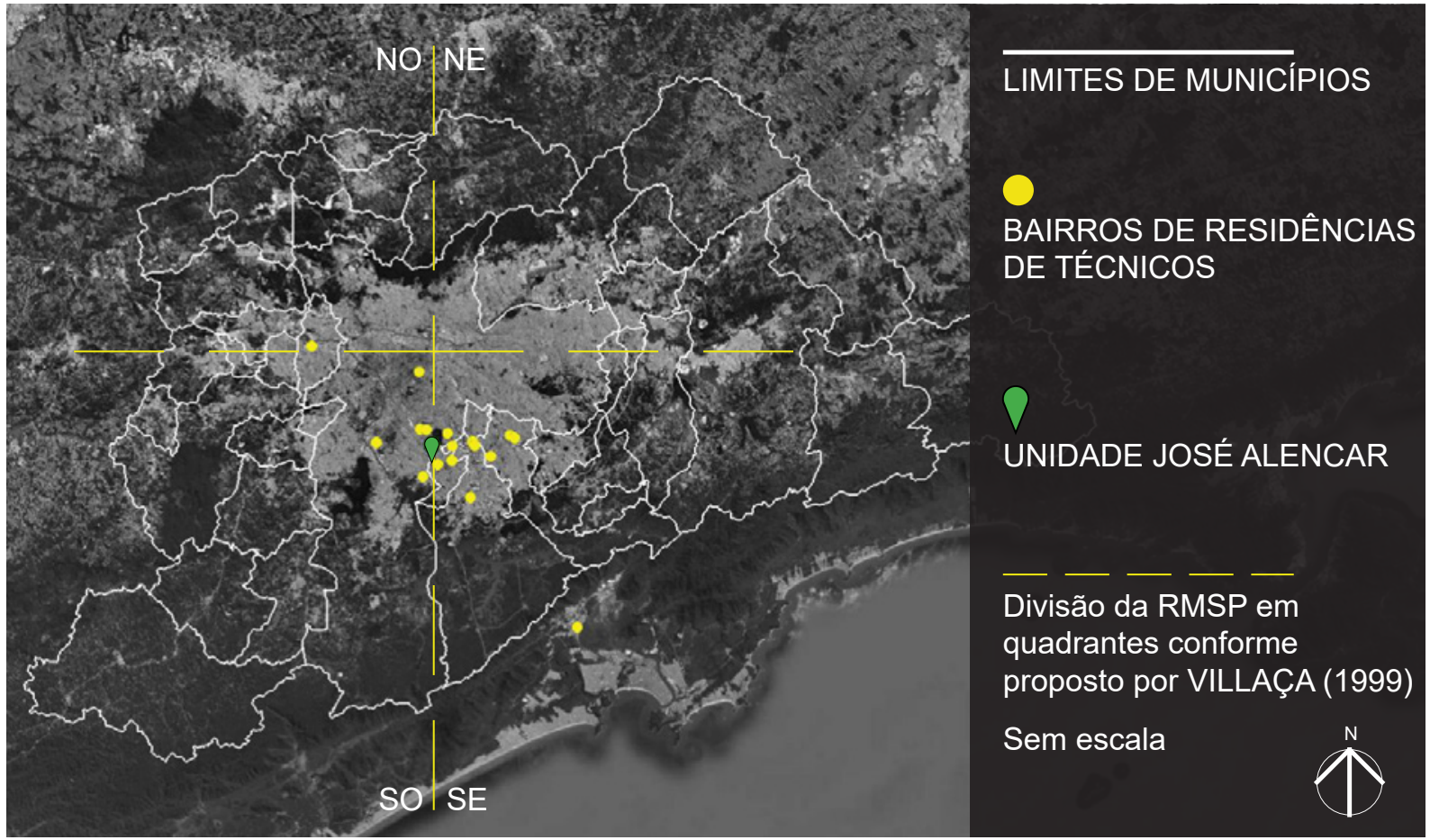

Fonte: Google Earth. Elaboração própria a partir de dados da enquete.

Considerando técnicos e docentes, a principal motivação para mudança de residência foi estar mais próximo ao local de trabalho. Entretanto, essa proximidade é relativa. Os técnicos que optaram por se mudar passaram a levar 20 minutos ou menos para se deslocarem da casa 
nova até o campus. Já entre os docentes, $81 \%$ dos que se mudaram têm tempos de deslocamento entre 30 e 60 minutos e 19\% têm abaixo de 30 minutos. Assim, percebe-se que há uma tolerância à distância e ao tempo de deslocamento entre residência e trabalho. Para docentes e parte dos técnicos, não morar em Diadema é uma opção, porque seus rendimentos permitiriam acessar a habitação nesse município ${ }^{34}$.

Figura 58 - Opção de técnicos por mudarem ou não a residência para trabalhar no campus Diadema, motivos para não terem mudado e, entre os que se mudaram, se optaram por Diadema ou outros municípios.

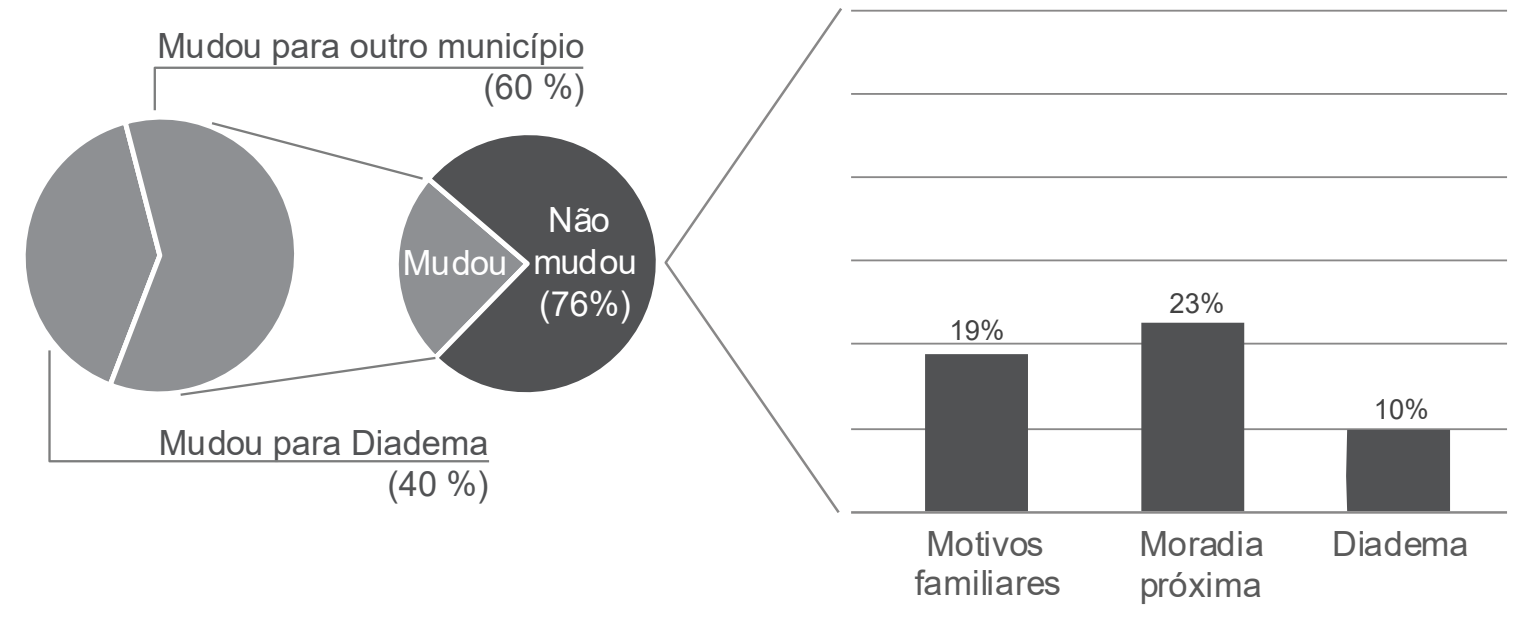

Fonte: Elaboração própria a partir de dados de enquetes.

Nesse sentido, Diadema tem uma grande vantagem quando comparado a outros municípios da RMSP. A proximidade ao metrô e a existência do corredor metropolitano de ônibus ampliam a acessibilidade. O corredor ABD vai do Jabaquara a São Mateus, passando por Diadema, São Bernardo e Santo André; sua variante vai de Diadema à Av. Berrini, em São Paulo. Além disso há integração tarifária e física nos terminais Jabaquara e Diadema. O transporte público é utilizado por $38 \%$ dos docentes e $42 \%$ dos técnicos.

Além disso, a sede administrativa do campus Diadema está há menos de 10 minutos a pé do terminal de ônibus de Diadema, e a maior parte de suas unidades também está próxima, à exceção da unidade José de Filippi, no bairro do Eldorado. Para conectar as unidades, o cam-

34 As remunerações para docentes e técnicos são estabelecidas pela lei 13.325, de 29 de julho de 2016. Para docentes, os valores básicos variam entre $\mathrm{R} \$ 2.236,31$ (para docente adjunto em regime de 20 horas semanais) a $\mathrm{R} \$ 8.833,96$ (para docente titular em regime de 40 horas semanais). A isso se podem somar valores retribuição por titulação da carreira do magistério federal, que para nível de doutorado o valor mínimo é de R $\$ 1.213,52$ para professor adjunto em regime de 20 horas semanais. Como todos os docentes da Unifesp têm doutorado, a remuneração mínima é de R\$3.449,83. Valores de agosto de 2018.

Já entre os técnicos, a remuneração varia entre $\mathrm{R} \$ 1.326,72$ a $\mathrm{R} \$ 8.323,87$. Em valores de janeiro de 2017. Para ambos os casos, além dos salários são acrescentados valores correspondentes à alimentação e transporte. 
pus dispõe de um sistema de ônibus circulares que, embora insuficiente, procura mitigar sua fragmentação.

A unidade José de Filppi pode ser acessada por ônibus municipais que partem do terminal Diadema. Entretanto, não há uma linha específica para atendê-la e os ônibus têm parada distante da unidade. Além disso, como é uma unidade muito próxima à divisa com São Paulo, partem deste município algumas linhas de ônibus que terminam seu percurso próximo à unidade José de Filippi, a 10 minutos de caminhada.

Outra alternativa de acesso a todas as unidades é o automóvel particular, utilizado por $57 \%$ dos docentes e $33 \%$ dos técnicos. Há quatro vias principais de acesso: a avenida Conceição, a rodovia dos Imigrantes, e a Av. Presidente Kenedy, que se conectam a São Paulo; e a avenida Fábio Eduardo Ramos Esquível, que se conecta a São Bernardo e Sando André. A figura 59 registra os meios de transporte utilizados por docentes e técnicos.

Figura 59 - Meios de transporte de docentes, técnicos e total para deslocamentos entre a residência e o campus Diadema.

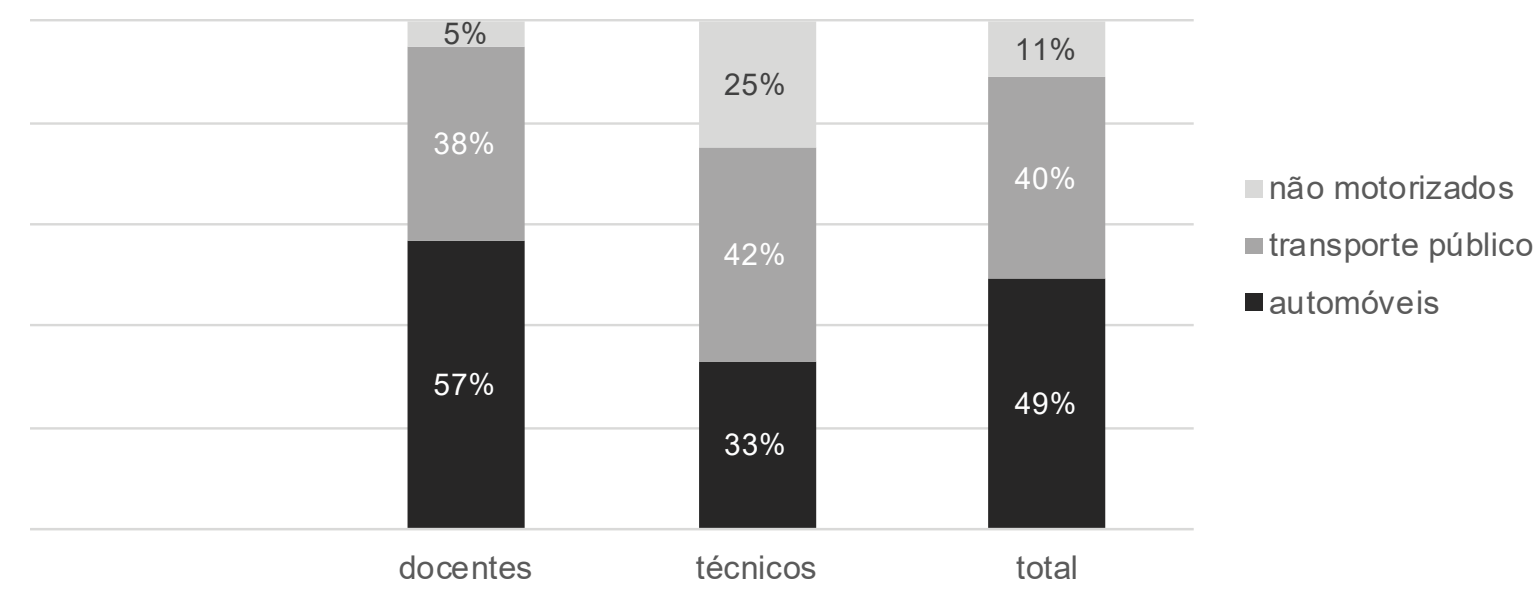

Fonte: Elaboração própria a partir de dados das enquetes.

Outro dado importante é que $71 \%$ dos técnicos e $74 \%$ dos docentes informaram não conhecer ou que não há atividades culturais e de lazer disponíveis no município. Entre os docentes, $15 \%$ das respostas citaram explicitamente usufruir do tempo livre em outros municípios, ainda que a pergunta não tenha questionado isso. Outras duas explicitaram que Diadema é local apenas para trabalho. Assim, é possível inferir que, dado o desconhecimento de opções em Diadema e que a maior parte dos técnicos e docentes resida em outros municípios, o tempo livre é aproveitado onde residem. 
Desta forma, a acessibilidade e a renda garantem a possibilidade de residir distante do campus. A relação que técnicos e docentes estabelecem com o município é, sobretudo, de trabalho, com movimentos pendulares, diferente de outros campi estudados pela bibliografia, como BRÜNE (2015) em Palotina e Toledo.

Nos dois casos estudados pela autora, a comunidade acadêmica reside no município onde estão os campi, portanto é onde fazem a maior parte dos seus gastos pessoais. Segundo a autora, os maiores gastos da comunidade acadêmica são com moradia e com o consumo de produtos e serviços. Já no caso deste estudo, docentes e técnicos realizam a maior parte dos seus gastos fora de Diadema, porque residem em outros municípios. Ainda assim, o volume de recursos provenientes dos salários de técnicos e docentes é irrisório perto das economias dos municípios da RMSP.

O local de moradia também indica que, diferente de campi em cidades pequenas ou médias, não houve uma expansão do mercado imobiliário para atender a uma nova demanda. Ainda que houvesse, o volume seria muito pequeno frente à população de Diadema. Não haveria necessidade de expansão urbana mesmo que toda a comunidade acadêmica tivesse sido atraída para junto do campus, como aconteceu em cidades pequenas e médias, como relatado por BRÜNE (2015) e BAUMGATNER (2015).

As razões para a comunidade acadêmica não residir em Diadema combinam a acessibilidade, a desigualdade territorial, desinteresse/desconhecimento do município e preconceito. Este último não ficou explicito nas enquetes nem nas entrevistas, mas permeiam o dia-a-dia do campus e é parte da justificativa da busca por outros municípios para abrigar o campus. Além disso, não se fala abertamente sobre os motivos que tornam Diadema desinteressante e o preconceito é disfarçado através de eufemismos. Apenas se diz que outros lugares são melhores, dessa forma bastante genérica, sem especificar os porquês. Todavia, sabe-se que impera no imaginário coletivo a ideia de um município violento, reflexo da sua condição dos anos 80 e 90 quando foi, de fato, um dos municípios mais violentos do país.

Outra parte das motivações para residir fora de Diadema é que outras partes da metrópole, sobretudo o quadrante sudoeste (onde mora a grande maioria dos docentes), dispõe de muito mais opções de lazer, comércio, serviço e cultura (teatros, museus e cinemas), além de ter melhor acessibilidade, ou seja, são áreas com maior valor de uso. Como o território é desigual, mas a acessibilidade é garantida, residir distante do trabalho é uma opção viável e desejada. 
Isso evidentemente se relaciona com o fator renda: quanto maior a renda, maior a capacidade de deslocamentos e vice-versa.

Outro fator importante para o desenvolvimento das regiões apontada pela bibliografia é a concentração de técnicos e docentes porque são um grupo com elevado grau de instrução e capacitação técnica. BAUMGARTNER, (2015) cita que isso, inclusive, pode alterar o perfil social dos municípios.

Entretanto, o que se constatou é que técnicos e docentes têm poucas relações com o espaço urbano em Diadema. Como apontado, a grande maioria não reside, não conhece e não desfruta de opções de lazer e cultura em Diadema; o tempo livre é aproveitado em outros municípios, geralmente o de origem. Além disso, apenas um técnico e três docentes afirmaram que participam de grupos políticos, conselhos ou similares em Diadema. A maior parte dos técnicos e docentes vai a Diadema apenas para trabalho e retorna ao município de origem logo em seguida.

Isso vai de encontro tanto ao que defende BAUMGARTNER, (2015) e ao que esperava José de Filippi Junior, que acreditava que a presença da universidade faria com que a comunidade acadêmica interagisse com as instituições, empresas, movimento e associações locais e regionais. Dos trabalhos levantados, só os de graduação e extensão da licenciatura mencionaram relações com escolas, poder público, e movimentos sociais.

Dessa forma, pode-se inferir que os impactos urbanos diretos, como citados em outros trabalhos, não têm relevância para o contexto de Diadema, por estar inserido dentro de uma metrópole desigual. Além disso, por não residirem em Diadema, não houve modificações significativas na composição social do município motivadas pela instalação do campus.

Outra possibilidade considerada é que a comunidade acadêmica induziria alterações significativas no entorno imediato dos campi, com alterações na oferta de comércio e serviços para atender à nova demanda. Todavia, a percepção que docentes e técnicos têm de alterações do entorno são muito pequenas e não motivadas pela instalação do campus.

Possíveis alterações passaram desapercebidas por $43 \%$ dos docentes e $38 \%$ dos técnicos. No total, foram $41 \%$ das respostas que não perceberam alterações no entorno. Mudanças relativas ao comércio foram citadas por $26 \%$ dos docentes, dentre estes, $54 \%$ se referiu à redução de oferta de comércio. Entre os técnicos, as alterações no comércio foram citadas em 34\% 
das respostas, dentre as quais $29 \%$ se refere ao fechamento de estabelecimentos comerciais. No total, $28 \%$ dos entrevistados citaram mudanças no comércio.

A mudança significativa mais citada foi a construção de novos edifícios, que representa $26 \%$ do total de respostas (36\% entre docentes e $24 \%$ entre técnicos). Mas, como afirmado acima, essa alteração não ocorreu devido à instalação dos campi, uma vez que uma minoria absoluta de técnicos e docentes optou por mudar-se para o entorno das unidades do campus. Em verdade, isso ocorre como resultado de uma expansão das frentes de atuação do mercado imobiliário na RMSP. Esses dados estão resumidos na figura 60.

Figura 60 - Percepção das mudanças no entorno das unidades do campus Diadema por Docentes, Técnicos e Totais

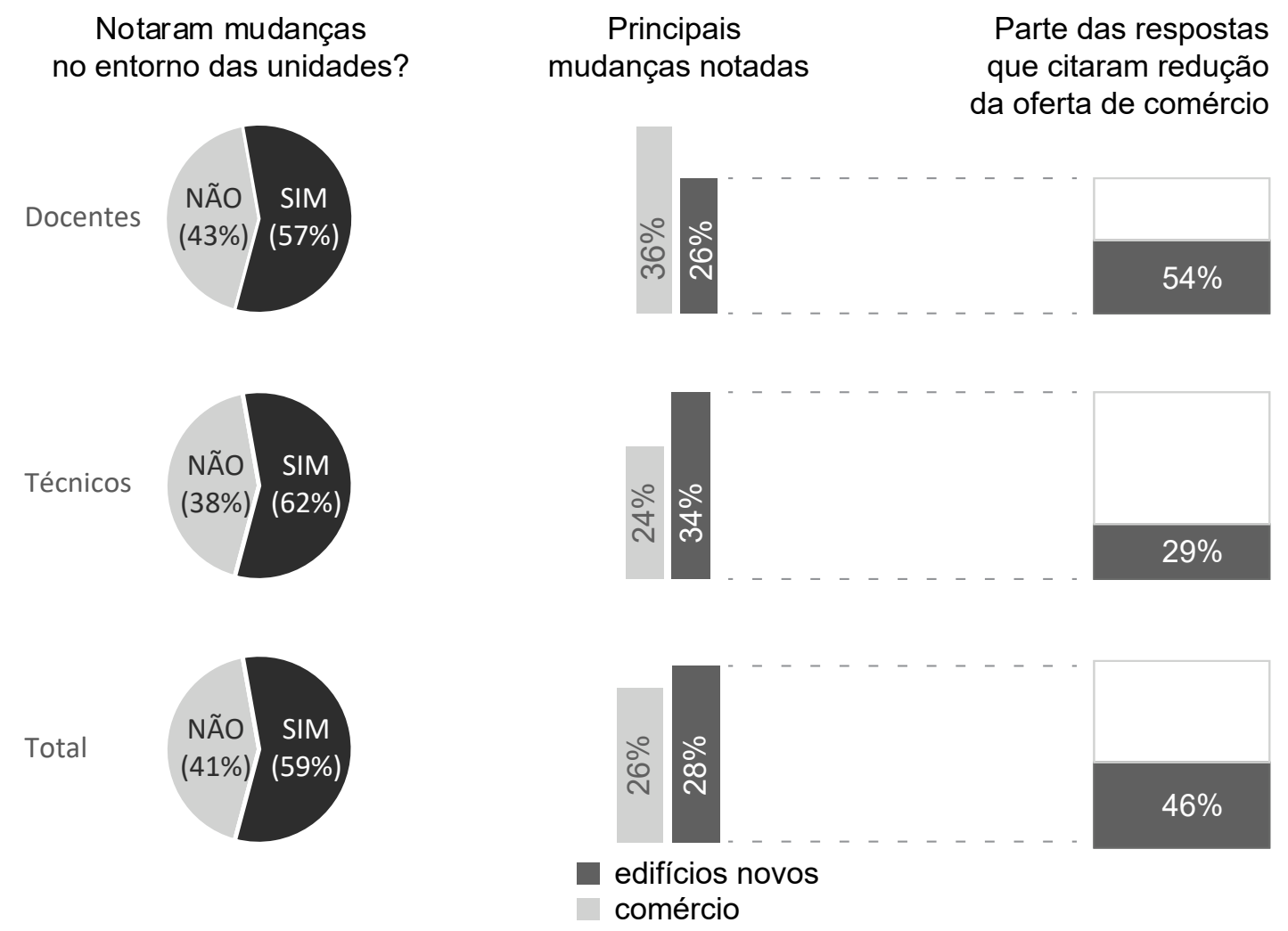

Fonte: Elaboração própria a partir de dados das enquetes.

Destaca-se dessas respostas aquelas dadas pelos docentes, divididos por bairros, de acordo com a unidade principal de trabalho. A mesma separação entre os técnicos não foi possível de ser realizada porque eles se concentram nas unidades do centro de Diadema, e apenas uma resposta apontou a unidade José de Filippi como unidade principal de trabalho. Essa separação foi realizada para verificar possíveis impactos do campus no bairro do Eldorado.

O que se constatou é que $63 \%$ dos docentes locados na unidade José de Filippi e 38\% dos locados nas unidades do centro não notaram mudanças no entorno. O dado que mais cha- 
mou a atenção é que o fechamento de comércio foi citado por $38 \%$ dos docentes da unidade José de Filippi e por apenas 9\% daqueles lotados nas unidades do centro, conforme figura 61.

Figura 61 - Percepção de docentes quanto a alterações no entorno e fechamento de comércios por unidades agrupadas.
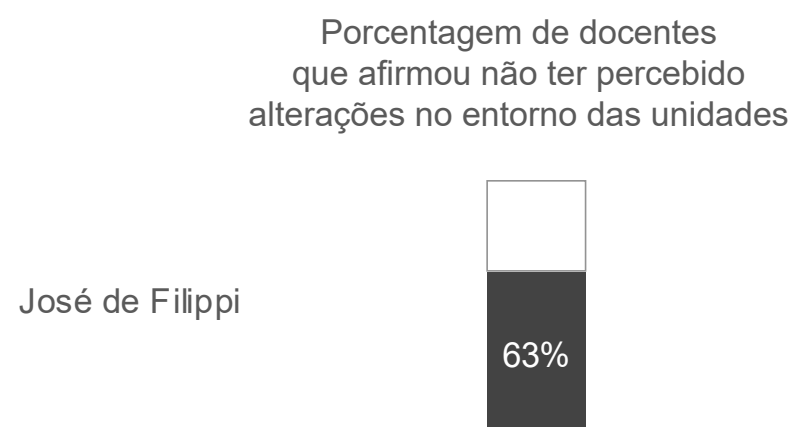

$3 \%$

Unidades do Centro

(José Alencar, Antônio Doll

Manoel da Nóbrega e

Florestan Fernandes)

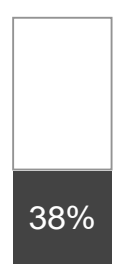

$38 \%$

\section{Porcentagem de docentes que mencionou fechamento de comércios}

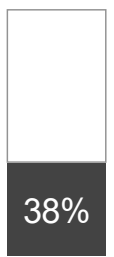

$38 \%$

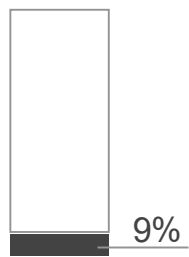

Fonte: Elaboração própria a partir de dados da enquete.

Entretanto, há que se considerar que a unidade José de Filippi, tem acesso pela estrada Pedreira-Alvarenga, que margeia a represa Billings. A grande parte dos vizinhos da unidade são residências e há pouco comércio, de fato. A grande e variada oferta de comércio e serviços do bairro é na avenida Nossa Senhora dos Navegantes a 500m da entrada da unidade José de Flippi (ver figura X, página Y). Por lá é possível encontrar supermercado, açougue, cabelereiros, e toda uma outra gama de comércio que atende à população residente. Apesar disso, há pouca oferta de restaurantes.

Assim, mudanças significativas, sobretudo a abertura de comércios, seriam mais perceptíveis junto a esta avenida do que próximo ao campus, o que fez supor que a comunidade acadêmica não a acesse com muita frequência, até porque, a oferta de restaurantes é pequena. De fato, $47 \%$ dos docentes daquela unidade disse que há poucos restaurantes no entorno. As poucas opções de alimentação são reclamações recorrentes no campus, e sobretudo na unidade José de Filippi.

Faz-se a ressalva de que há, padarias e restaurantes no entorno de todas as unidades, nem sempre próximas, mas há o fator de padrão de consumo: não basta existir opções, é preciso que a oferta atenda a algumas exigências de qualidade. 
Em conversas informais se apontou, também, a falta de outros estabelecimentos, como papelarias, cafés e bares, que complementam o espaço da universidade, que permeiam o espaço urbano. Isso foi confirmado pela observação do entorno das unidades do campus. Logo, entende-se que o campus produziu pouco ou nenhum impacto sobre o entorno imediato. Além dos motivos já mencionados, pode-se acrescentar a fragmentação do campus, porque apesar de ser uma comunidade acadêmica composta por 2000 estudantes, 250 docentes e 110 técnicos (2360 pessoas, no total, portanto), espalhados nas 6 unidades do campus.

Essa fragmentação é um impacto direto do contexto urbano sobre o campus e têm origem na forma de expansão do campus assim como na própria formação do espaço urbano em Diadema. Como o padrão varia entre pequenos edifícios em lotes pequenos, autoconstrução e indústrias, não houve a possibilidade de concentrar o campus em um ou dois edifícios já construídos.

A saída encontrada pelo campus foi a execução de um projeto próprio, à beira da represa que, inclusive tinha como propósito induzir transformações no seu entorno, mas que foi barrado pelos órgãos ambientais, como comentado no início deste capítulo. A impossibilidade de ter um edifício próprio único, construído ou adquirido, forçou o campus à fragmentação.

A fragmentação tem outra importância: a repetição de serviços básicos em cada uma das unidades, como segurança e limpeza, a necessidade de deslocamento de técnicos para fiscalização dos serviços e das condições das unidades, o que lhes toma tempo, e a necessidade de um sistema próprio de transporte, que conta tanto com ônibus circulares, como com uma frota de carros e motoristas para permitir o deslocamento de técnicos e docentes entre as unidades.

Uma outra possibilidade que se considera na bibliografia é sobre o consumo do campus. A demanda por materiais de escritório (papel, canetas, etc), até insumos específicos para aulas e pesquisas (como produtos químicos, vidrarias, entre outros) além de serviços terceirizados, poderia dinamizar o comércio e serviços locais.

Todavia, diferentemente de uma empresa privada, as aquisições e contratos do campus são realizados via licitações, regulamentadas pela lei no 8.666, de 21 de junho de 1993 (BRASIL, 1993). A legislação prevê livre participação de empresas de todo o país para fornecimento de materiais e, para o caso de serviços, as empresas podem até ser de outras regiões e Estados, mas devem ter uma unidade próxima ao órgão. 
É possível mapear a origem das empresas prestadoras de serviços ou fornecedoras de produtos e insumos através do site "Portal de Compras" 35 do governo federal. A tabela 8 , a seguir, indica alguns dos principais serviços e materiais que o campus licitou entre 2015 e $2018^{36}$.

Tabela 8 - Serviços e produtos consumidos pelo campus e origem das empresas fornecedoras.

\begin{tabular}{|l|l|l|}
\hline Serviço ou produtos & Pregão & Sede \\
\hline Manutenção predial & $400 / 2016$ & Salvador-BA \\
\hline Manutenção de elevadores & $19 / 2018$ & São Paulo-SP \\
\hline Manutenção de ar condicionado & $353 / 2015$ & São Bernardo do Campo - SP \\
\hline Manutenção de áreas verdes & $48 / 2017$ & Campinas \\
\hline Limpeza de reservatórios de água & $391 / 2018$ & Santo André-SP \\
\hline Seguro de Imóveis & $14 / 2015$ & São Paulo - SP \\
\hline Seguro de Veículos & & \\
\hline Serviço de motoristas & $14 / 2015$ & São José do Rio Preto - SP \\
\hline Controle de pragas urbanas & $70 / 2018$ & São Paulo-SP \\
\hline & $39 / 2018$ & Santo André-SP \\
\hline Insumos para laboratórios didáticos & & \\
& & São Paulo-SP \\
& \multirow{2}{*}{$06 / 2015$} & Vila Santo Estefano \\
\cline { 3 - 3 } & & Sumaré - SP \\
\cline { 3 - 3 } & & Jandira - SP \\
\hline Fornecimento de nitrogênio líquido & $34 / 2015$ & Jundiaí \\
\hline Fornecimento de Galões de 20L de água & $99 / 2017$ & Praia Grande-SP \\
\hline Vidrarias para laboratórios & $276 / 2017$ & São Paulo-SP \\
\hline Aquisição de livros & & Florianópolis-SC \\
\cline { 3 - 3 } & \multirow{2}{*}{$71 / 2018$} & São Paulo-SP \\
\cline { 3 - 3 } & São Paulo-SP \\
\cline { 3 - 3 } & & \\
& &
\end{tabular}

Fonte: Portal de Compras - Elaboração própria.

Desta forma, pode-se confirmar pela tabela que os fornecedores de produtos e serviços do campus Diadema tem sede em outros municípios que não Diadema. Em geral eles estão divididos entre o interior do Estado e a própria capital, e em alguns casos até em outros Estados ${ }^{37}$. A hipótese de que o consumo do campus pudesse trazer algum dinamismo para a região do $\mathrm{ABC}$, mas especialmente para Diadema, não se confirma.

Portanto, não há impactos diretos sobre o espaço urbano que sejam motivados pela instalação do campus. Entretanto, como se pôde verificar em outras seções deste capítulo, a influência do campus sobre o espaço e o desenvolvimento urbano, pode se dar de forma indireta e a longo prazo.

35 Disponível em http://comprasnet.gov.br. Acesso em 19/12/2018.

$36 \mathrm{O}$ ano de 2015 foi considerado inicial para busca porque os contratos realizados anteriormente já não podem mais ser renovados a partir de 2019.

37 Para o caso de serviços continuados é necessário que a empresa tenha ao menos uma filial próxima ao campus. Nessa categoria encontram-se, por exemplo, os serviços de manutenção. 
Outras duas questões relativas à relação do campus com o espaço urbano dizem respeito à construção de novos edifícios e à Revisão do Plano Diretor de Diadema. A expansão do campus acontecerá dentro da unidade José de Alencar, cujo uso de solo anterior era industrial, com destaque para as indústrias metalúrgica, química, de plástico e de tintas.

Essa atividade encontra-se em retração e tem deixado edificações e lotes vazios ou subutilizados, que são apropriadas para outros usos, a exemplo da Mooca, onde os terrenos de antigas indústrias cedem espaço para residências. Isso não significa apenas que o campus se insere dentro de um processo de transformação urbana, mas que a ele restam os ônus dessas mudanças.

Segundo o informativo "Investigações e Ações Ambientais da Unifesp na Unidade José Alencar -Prédio Didático"38, elaborado pela divisão de Gestão Ambiental do campus em parceria com as empresas contratadas para avaliação ambiental, há contaminantes no solo e na água subterrânea mas "não há exposição aos poluentes acima do aceitável” pela CETESB - Companhia Ambiental do Estado de São Paulo. Ainda assim, o passivo ambiental, legado do uso industrial anterior, representa um volume elevado de trabalho e de uso de recursos financeiros da universidade.

De acordo com a apresentação "Plano de Investigações e Ações Ambientais na Unidade José Alencar - Complexo Didático do Campus Diadema"39, até agosto de 2018 haviam sido gastos um total de R\$856.243,12 com as avaliações ambientais. Segundo a mesma apresentação, ainda há necessidade de seguir os estudos, mas sem estimativa de valores.

Já a revisão do Plano Diretor foi organizada pela prefeitura em discussões divididas em seis eixos temáticos: Política Habitacional; Meio Ambiente; Comércio; Indústria; Serviços e Tecnologia; e Infraestrutura Urbana. O campus diadema participou mais ativamente das discussões dos eixos "Indústria" e "Serviços e Tecnologia". Em ambos a questão de inovação teve destaque. Segundo notícia veiculada no site da prefeitura, "para promover o crescimento econômico da cidade, que é um dos objetivos do Plano Diretor, o município quer fomentar a inovação tecnológica na cidade." ${ }^{40}$.

38 Disponível em: <http://www.unifesp.br/campus/dia/component/phocadownload/category/4-institucional?download=990:folheto-informativo $>$. Acesso em 14/09/2018.

39 Disponível em: <http://www.unifesp.br/campus/dia/component/phocadownload/category/10-administrativo?download=986:informedepassivoambiental-rev>. Acesso em 14/09/2018.

40 Disponível em < http://www.diadema.sp.gov.br/noticias/23168-plano-diretor-de-diadema-encerra-segunda-rodada-de-discussoes-tematicas?highlight=WyJwbGFubyIsImRpcmV0b3IiLCJwbGFubyBkaXJldG9yIl0=> .

Acesso em 14/09/2018 
Segundo João Alexandrino, é através desses eixos que diversos agentes passaram a se reunir sob a condução da Secretaria de Desenvolvimento Econômico e Trabalho. Foi desta reunião que surgiu a ideia do plano “Diadema, Cidade Inteligente”. Este plano, assim como o Polo e o Parque Tecnológicos ${ }^{41}$, são os espaços que a prefeitura tem criado para permitir a interação de diversos agentes do desenvolvimento urbano e regional e contam com a colaboração do campus Diadema. 


\section{CONSIDERAÇÕES FINAIS}

A proposta desta pesquisa nasceu da observação do contraste entre o espaço urbano e as demandas do campus Diadema da Unifesp. Por um lado, a condição urbana parecia um fator limitante às potencialidades do campus; por outro, era evidente a importância de um campus de uma universidade federal fora da área central da metrópole, ainda mais considerada junto aos demais campi da Unifesp, conformando o anel universitário.

A questão colocada era saber de que formas o campus poderia ser parte do desenvolvimento urbano e regional, sabendo que são processos correlatos e fruto de trabalho social, resultado da atuação de diversos agentes. Portanto, interessa compreender a atuação do campus enquanto um dos agentes e como ele pode provocar transformações. A bibliografia consultada apontou referenciais teóricos sobre a relação entre universidades e desenvolvimento urbano e regional e, a partir deles, procurou-se levantar e interpretar ações do campus Diadema.

As principais formas de atuação das universidades em prol do desenvolvimento urbano e regional encontrados dizem respeito a impactos urbanos gerados pela instalação do campus, pela formação de capitais intangíveis, pelas transformações de ordem socioeconômica e pelo "efeito conhecimento" sobre a produção industrial.

De partida, já se imaginava que os impactos urbanos seriam de menor importância, se não desprezíveis. Isso porque se trata de um contexto de urbanização consolidada dentro de uma metrópole (a de São Paulo, mais especificamente), diferentemente de toda a bibliografia consultada, que focou em cidades de pequeno e médio porte. Tal hipótese se confirmou a partir da análise das respostas de técnicos e docentes do campus sobre sua relação com o espaço urbano em Diadema. Os dois grupos frequentam Diadema sobretudo por motivos ligados a trabalho, enquanto a residência e outras atividades concentram-se nos municípios vizinhos, sobretudo São Paulo, São Bernardo e Santo André, que têm localizações com maior valor de uso.

Verificou-se, também, que ainda não foram causadas transformações no espaço urbano, tanto no que diz respeito à disponibilidade e qualidade de infraestrutura quanto a mudanças na oferta de comércio e serviços nos arredores das unidades. Entre os motivos elencados estão a urbanização consolidada, a infraestrutura completa (ainda que insuficiente) e a fragmentação do campus em cinco unidades. Isso contradiz a expectativa de que a instalação de um campus 
universitário possa induzir transformações, conforme a bibliografia e à expectativa da prefeitura de Diadema à época da criação do campus.

Apesar disso, a condição urbana de Diadema impõe-se. Ela foi determinante para a fragmentação do campus, ao mesmo tempo que a disponibilidade de grandes lotes industriais significou uma oportunidade. Ainda assim, é da própria formação do espaço urbano que advém um grande desafio para o campus: a industrialização deixou o legado de grandes terrenos, porém contaminados.

É também a partir do entendimento da formação do espaço urbano que foram interpretadas as ações do campus. A baixa escolaridade advinda do processo de industrialização foi superada, mas ainda persiste a baixa qualidade do ensino público, o que mantém a restrição ao acesso do jovem diademense à universidade pública. Em oposição a esse fato, há os trabalhos de extensão (cursinho popular e formação de professores) e a graduação em licenciatura, que têm intenção de melhorar o ensino público em Diadema, assim como a ampliar o acesso à universidade pública.

Apesar da importância dessas iniciativas, há entraves para o seu pleno desempenho. Parte delas tem origem na própria condição urbana, que leva diretores das escolas a recomendarem que docentes e estudantes do campus não realizem trabalhos nas escolas mais afastadas do centro de Diadema. Outra parte é relativa às dificuldades impostas pelos sistemas de ensino e falta de articulações entre as políticas federal, estadual e municipal, que inibem o trabalho do campus junto às instituições de ensino básico.

Mesmo assim, as ações do campus para qualificar o ensino, seja por meio da formação primária e continuada de professores para a rede pública, seja por iniciativas diretas em escolas ou por meio do cursinho popular, podem representar uma ruptura com um processo histórico que não garantiu acesso ao ensino fundamental e médio de qualidade a $90 \%$ dos jovens de Diadema.

A longo prazo, tais atividades podem ser parte de uma transformação social; a democratização do ensino de qualidade é também um fator importante para a formação de capital humano, não tendo somente função utilitarista, de capacitação de mão-de-obra para as atividades econômicas, mas também orientada à educação de cidadãos críticos, conscientes de sua condição, deveres e direitos. 
Sobre o tema do capital humano, destaca-se, também, que é importante um estudo dedicado à real capacidade e interesse das empresas e indústrias empregarem os estudantes egressos do campus. Indícios levantados por este trabalho apontam que há pouco interesse das indústrias da região em empregar mão-de-obra qualificada pela Unifesp.

Esses mesmos indicadores são causas para o afastamento entre campus e indústrias. $\mathrm{O}$ que se evidenciou é que, apesar de parte dos cursos terem sido determinados de acordo com as principais indústrias de Diadema e região, há poucas parcerias estabelecidas entre este e aquelas. Entre os principais motivos estaria a diferença de tempo entre os trabalhos da universidade e das necessidades do setor industrial e sua relação com a variável tecnológica.

A aplicação do "efeito conhecimento" tem, portanto, uma importância menor do que sua potencialidade para transformar a realidade da região a partir do incremento da pesquisa e inovação nas atividades produtivas, o que vai de encontro a parte importante das considerações da bibliografia.

Já com relação a outros capitais intangíveis (institucional, social e sinérgico), o que se pôde observar é que faltam as devidas articulações para que eles se efetivem. O campus tem se inserido como um agente importante em meio a indústrias e demais instituições, como Ciesp, Sesi, Senai, a prefeitura de Diadema e outras universidades. Contudo, as articulações com esses grupos têm sido criadas recentemente, após um período em que o campus voltou-se para si e superou dificuldades nas relações com a prefeitura.

Essas articulações podem ser resultado da aplicação de políticas públicas, sobretudo de desenvolvimento urbano e regional e suas correlatas políticas setoriais. Entretanto, apesar de ter sido elaborada, a PNDR não chegou a sair do papel e, mesmo assim, não continha as articulações com as políticas públicas setoriais que pudessem dirigir as ações das universidades para o desenvolvimento das diversas regiões do país ${ }^{42}$.

Desse modo, apesar das políticas de expansão das universidades federais previrem a instalação de universidades e campi como motivadores do desenvolvimento regional, faltaram definições sobre como isso aconteceria e que direção deveria ter. Diante dessa ausência de guias, grande parte das parcerias levantadas por este trabalho são pesquisas específicas, individuais ou de grupos, que encontraram empresas ou órgãos públicos interessados, não necessariamente 
pertencentes à região do $\mathrm{ABC}$, mas ligadas a outras regiões, até estrangeiras. Da mesma forma, os projetos de extensão são todos frutos de iniciativas de docentes e não estão sob a orientação e organização de uma política pública.

Nesse sentido, a retomada e o aprofundamento das relações entre campus e prefeitura nos anos de 2017 e 2018 tem sido permeada pela iniciativa da municipalidade de criar políticas públicas setoriais que passam a demandar mais as ações do campus de forma coordenada. Dentre essas iniciativas está a revisão do plano diretor do município[2] e o plano "Diadema: cidade inteligente". Este último tem participação efetiva do campus por meio da elaboração do Atlas Ambiental.

Além dessas, e com foco nas indústrias, campus e prefeitura têm se debruçado na formulação de um polo e um parque tecnológicos. Essas iniciativas são importantes para a formação dos capitais institucional, social e sinérgico, sobretudo a partir das articulações de que dependem, por meio da reunião dos diversos agentes que atuam para o desenvolvimento urbano e regional.

Por outro lado, uma parte dos trabalhos de pesquisa tem parcerias regionais com órgãos públicos, como a Cetesb e o MPF, sobretudo em questões ambientais. Esses trabalhos permitirão uma melhor fiscalização e maior rigidez na aplicação de sanções, além de garantir um sentido público para o uso do conhecimento e da pesquisa do campus.

Algumas dessas parcerias são resultado da busca da universidade por novas fontes de recursos, diante a redução drástica de orçamento para as instituições federais de ensino superior nos últimos anos. Em partes, o próprio campus mudou sua postura com relação à comunidade externa devido à necessidade de se buscar saídas para a crise econômica, social e política que o país enfrenta. Apesar de todos os malefícios da falta de estabilidade econômica, diversos agentes têm buscado por novas parcerias como forma de contornar as restrições impostas, o que representa uma oportunidade de se realizarem as articulações necessárias para o desenvolvimento urbano e regional.

Por fim, considera-se que o campus tem um grande potencial para ser parte da indução do desenvolvimento urbano e regional, sobretudo pela sua especificidade programática. Todavia, há entraves na própria construção do campus, na condição urbana em que se insere e, sobretudo, na estrutura político-econômica do país e na falta de articulações da política de desenvolvimento regional com as políticas de educação superior e de pesquisa, tecnologia e inovação. 


\section{REFERÊNCIAS}

ABRAMO, Pedro. A cidade COM-FUSA: a mão inoxidável do mercado e a produção da estrutura urbana nas grandes metrópoles latino-americanas. Revista Brasileira de Estudos Urbanos e Regionais. v. 9, n. 2, p. 25-54. nov 2007

ARAÚJO, Tânia Bacelar de. Desenvolvimento regional brasileiro e políticas públicas federais no governo Lula. In: SADER, Emir. 10 anos de governos pós-neoliberais no Brasil: Lula e Dilma. São Paulo: Boitempo, 2013. p 157-172.

ARBIX, Glauco. Estratégias de inovação para o desenvolvimento. Tempo Social, revista de sociologia da USP, v. 22, n. 2, p. 167-185. nov 2010.

AUREA, Adriana Pacheco. GALVÃO, Antonio Carlos F. Importação de tecnologia, acesso às inovações e desenvolvimento Regional: O Quadro Recente no Brasil. Brasília, dezembro de 1998

BARBOSA, Marcelo Ponte; PETTERINI, Francis Carlo; FERREIRA, Roberto Tatiwa. Avaliação do impacto da política de expansão das universidades federais sobre as economias municipais. In: Anais do $43^{\circ}$ Encontro Nacional de Economia. 2015. Disponível em https:// www.anpec.org.br/encontro/2015/submissao/files_I/i12-6599011d2e3082ef34b038002f88e4 1c.pdf. Acesso em 03 de janeiro de 2018.

BARROS, Aparecida da Silva Xavier. Expansão da educação superior no Brasil: Limites e Possibilidades. Revista Educação e Sociedade, Campinas, v.36, ed.131, p. 361-390, abr-jun de 2015.

BAUMGARTNER, Wendel Henrique. Cidades universitárias, cidades médias, cidades pequenas: Análises sobre o processo de instalação de novos campi universitários. Revista Espaço Aberto, Rio de Janeiro, ed. 01, p. 73-93, 2015.

BONDUKI, Nabil Georges. Habitação popular: contribuição para o estudo da evolução urbana de São Paulo. In: VALLARES, Licia do Prado. Repensando a habitação no Brasil. Rio de Janeiro. Zahar, 1983. p. 135-168.

BRITO, Leonardo Chagas de. A importância dos estudos sobre interiorização da universidade e reestruturação territorial. Revista Espaço e Economia. Ano 2, n. 4, 2014.

ROLNIK, Raquel. A periferia da Grande São Paulo. Reprodução do espaço como expediente de reprodução da força de trabalho. In: MARICATO, Ermínia. (org). A produção capitalista da casa (e da cidade) no Brasil Industrial. São Paulo: Editora AlfaÔmega, 1979

BOWLES, Samuel. GINTIS, Hebert. El problema de la teoria del capital humano: una critica Marxista. Revista de Economía Crítica, nº18, p. 2014. 
BRASIL. Ministério da Educação. Plano Nacional de Educação. Brasília: Inep, 2001.

. Ministério da Educação. Secretaria da Educação Superior. Plano de Desenvolvimento da Educação. Brasília: Inep, 2007.

BRASIL. Política Nacional de Desenvolvimento Urbano. Brasília, DF. 2004

. Ministério da Educação. O Plano de Desenvolvimento da Educação: Razões, princípios e programas. Disponível em: $<$ http://portal.mec.gov.br/arquivos/livro/livro.pdf $>$. Acesso em 19 fev 2018.

.Avaliação da política nacional de desenvolvimento regional. Brasília. 2011. Disponível em $<$ http://www.integracao.gov.br/documents/4085233/0/PNDR_2012+\%281\%29.pdf/1e31fb5df09c-4a8e-8a71-5784c210633e>. Acesso em 16/01/2019

. Ministério da Educação. Análise sobre a expansão das Universidades Federais: 2003 a 2012. Brasília. 2012. Disponível em: < http://portal.mec.gov.br/index.php?option=com docman\&view=download\&alias=12386-analise-expansao-universidade-federais-2003-2012pdf\&Itemid=30192>. Acesso em 19 fev 2018.

BRÜNE, Sabrina.. Instituições de ensino superior e desenvolvimento: o caso do programa Reuni. 2015a. Dissertação (Mestrado) - Universidade Estadual do Oeste do Paraná, Toledo.

Instituições de ensino superior e desenvolvimento: impactos econômicos de curto prazo de universidades federais do oeste paranaense. Revista Brasileira de Pós-Graduação, Brasília, v. 12, ed. 28, p.537-560, 2015 b.

CARINHATO, Pedro Henrique. Neoliberalismo, reforma do estado e políticas sociais nas últimas décadas do século XX no Brasil. Revista Aurora. vol. 2. n 3, p. 37-43. Dez 2008.

CARLEIAL, Liana; CRUZ, Bruno. Estratégia de desenvolvimento regional política pública negociada e novas institucionalidades. Boletim Regional, Urbano e Ambiental, Brasília, n. 03, p. 15-22, dez 2009.

DELGADO, Guilherme Costa; THEODORO, Mário. Desenvolvimento e política social. In: JACCOUD, Luciana. Questão social e políticas sociais no Brasil contemporâneo. Brasília: IPEA, cap. 9, p. 409-435. 2005.

CALDEIRA, Teresa Pires do Rio. Cidade de Muros: crime, segregação e cidadania em São Paulo. São Paulo: Ed. 34 / Edusp. 2000

FURTADO, Celso. Pequena introdução ao desenvolvimento. São Paulo: Ed. Nacional. 1980.

GENTILI, Pablo; OLIVEIRA, Dalila Aandrade. A procura da igualdade: dez anos de política educacional no Brasil. In: SADER, Emir. 10 anos de governos pós-neoliberais no Brasil: Lula e Dilma. São Paulo: Boitempo. 2013. p. 253-264.

GIARDINI, Douglas de Almeida. SANCHES, Ronaldo. Ocupação dos egressos do curso de 
Engenharia Química da Universidade Federal de São Paulo. Dissertação (Trabalho de Conclusão de Curso). Universidade Federal de São Paulo. 2016

HADDAD, Paulo Roberto. Capitais intangíveis e desenvolvimento regional. Revista de Economia, Curitiba, v. 35, ed.3, p. 119-146, set-dez de 2009.

HADDAD, Fernando. Vivi na pele o que aprendi nos livros. Revista Piauí, Jun 2017. Disponível em <https://piaui.folha.uol.com.br/materia/vivi-na-pele-o-que-aprendi-nos-livros/>. Acesso em: 18 dezembro 2018

JESUS, Jorge Alberto Santana de. A política de expansão e interiorização do ensino superior através da Universidade Aberta do Brasil: a experiência da UNIVASF no Vale do submédio São Francisco. 2016. Dissertação (Mestrado) - Universidade Federal do Recôncavo da Bahia, Cruz das Almas.

JOSÉ, André Borsa. O processo de desindustrialiazação no Ipiranga e suas consequências socio-espaciais. 2010. Dissertação (Mestrado) Universidade de São Paulo, São Paulo.

JUNIOR, Licio Gonzaga Lobo. Dinâmicas territoriais, conflitos e forma urbana em Diadema/ sp. In: Anais do I circuito de debates acadêmicos. 2011. Disponível em < http://www.ipea.gov. br/code2011/chamada2011/pdf/area7/area7-artigo20.pdf>. Acesso em 09/01/2019.

LANGENBUCH, Juergen Richard. A estruturação da grande São Paulo - estudo de geografia urbana. Rio de Janeiro: Instituto Brasileiro de Geografia, Departamento de Documentação e Divulgação Geográfica e Cartográfica. 1971.

LAURENTINO, Fernando de Pádua. Várzeas do Tamanduateí: industrialização e desindustrialização. 2002. Universidade de São Paulo, São Paulo.

LIMA, Antônio Ernani Martins. A Teoria do Desenvolvimento Regional e o papel do Estado. Revista Análise Econômica, Porto Alegre, ano 24, n. 45, p. 65-90, mar 2006.

MADUREIRA, Eduardo Miguel Prata. Desenvolvimento regional: Principais teorias. Revista Thêma et Scientia, Cascavel, v. 5, ed. 02, p. 8-23, jul/dez 2015.

MANCEBO, Deise; VALE, Andréa Arajudo do; MARTINS, Tânia Barbosa. Políticas de expansão da educação superior no Brasil: 1995-2010. Revista Brasileira de Educação, Rio de Janeiro, v. 20 ed. 60, p. 31-50. jan-mar de 2015.

MARICATO, Ermínia. Metrópole na periferia do capitalismo: ilegalidade, desigualdade e violência. São Paulo: Hucitec, 1996

O impasse da política urbana no Brasil. Petrópolis: Vozes, 2014.

NASCIMENTO, Francivaldo Santos; HELAL, Diego Henrique. Expansão e Interiorização das universidades federais: uma análise do processo de implementação do campus do litoral norte da Universidade Federal da Paraíba. Revista GUAL, Florianópolis, v. 8, ed.1, p.45-67. jan de 2015 . 
NIGRIELLO, Andreína. OLIVEIRA, Rafael Henrique. Região Metropolitana de São Paulo: Delimitação e Caracterização de Unidades Territoriais Metropolitanas in: Cadernos de PósGraduação em Arquitetura e Urbanismo: Programa de Pós-Graduação em Arquitetura e Urbanismo FAU Mackenzie. v. 13, n. 1, 2013. Pp 102 - 147.

OLIVEIRA, Gilson Batista de. Uma discussão sobre o conceito de desenvolvimento. Revista da FAE, Curitiba, v. 5, n. 2, p. 37-48, maio/ago 2002.

PADIM, Dayto Fernando. A expansão e interiorização da Universidade Federal de Uberlândia: um processo de democratização?. 2014. Dissertação (Mestrado) - Universidade Federal de São Carlos. São Carlos.

PAIVA, Vanilda. Sobre o conceito de capital humano. Cadernos de Pesquisa. N. 113, p. 185191. jun 2001.

PINHEIRO, Sheila da Silva. Metrópole e políticas públicas: a centralidade difusa do município de Diadema. Mestrado. Universidade Presbiteriana Mackenzie. 2007

POLI DE FIGUEIREDO. Gabriel Mazzola. O discurso e a prática da Smart City: perspectivas críticas e aproximações. Dissertação (Mestrado). Universidade de São Paulo. 2018

REZENDE, Sérgio Machado. Uma década de avanço em ciência, tecnologia e inovação no Brasil. In SADER, Emir. 10 anos de governos pós-neoliberais no Brasil: Lula e Dilma. São Paulo: Boitempo. 2013. p. 265-284.

ROLNIK, Raquel. A cidade e a lei: legislação, política urbana e territórios na cidade de São Paulo. São Paulo: Estúdio Nobel/Fapesp. 1997

SANTANA, Elisandro Trindade; MARENGO, Shanti Nitya. A Universidade Federal do Recôncavo como política de desenvolvimento regional no espaço intraurbano de Santo Antônio de Jesus. Revista GeoTextos, Salvador, v. 8 ed. 2, p; 35-57, dez. 2012.

SANTOS, Mauricleia Soares dos. A Política habitacional no município de Diadema e a intervenção do assistente social (1994 - 2004). Mestrado. PUC-SP. 2006.

SILVA, José Alves da. Rangel, Flamínio de Oliveira. COLAGRANDE, Elaine Angelina. FERREIRA, Anna Vivian Tabosa S. CARDOSO, Cesar Rogério. OLIVEIRA. Eloisa Neri de. PEREIRA, Cirilo Rodrigo de Aniz. SILVEIRA, Thiago Graça da. Evasão e Vulnerabilidade acadêmica em curso de formação de professores de ciências. In: Atas do IX Encontro Nacional de Pesquisa em Educação em Ciências. Águas de Lindóia. 2013. Disponível em http://www. nutes.ufrj.br/abrapec/ixenpec/atas/resumos/R0284-1.pdf. Acesso em 07/01/2019

SILVA, Franklin Leopoldo e. Universidade, cidade e cidadania. In: JOSÉ, Valter (Org.). Universidade, cidade e cidadania. São Paulo: Hedra, 2014. p. 117-129

SINGER, Paul. A recente ressurreição da economia solidária no Brasil. In SANTOS, Boaventura de Souza. Produzir para viver: os caminhos da produção não capitalista. Rio de Janeiro: 
Civilização Brasileira. 2005

UNIVERSIDADE FEDERAL DE SÃO PAULO. Plano Diretor de Infraestrutura do campus Diadema. Disponível em <https:/www.unifesp.br/reitoria/proplan/pdinfra/pdinfra-titulo/ campus-diadema/plano-diretor-documentacao-completa $>$. Acesso em 18/12/2018

VAINER, C. Cidade de Exceção: reflexões a partir do Rio de Janeiro. In: Anais do XIV Encontro Nacional da Associação Nacional de Planejamento Urbano (ANPUR). V. 142011. Disponivel em: $<$ https://br.boell.org/sites/default/files/downloads/carlos_vainer_ippur_cidade_ de_excecao_reflexoes_a_partir_do_rio_de_janeiro.pdf $>$. Acesso em 15/02/2018

VIEIRA, Danilo Jorge. Evolução do ensino superior no brasileiro em período recente: novas perspectivas para o desenvolvimento regional? In: NETO, Aristides Monteiro; CASTRO, César Nunes de; BRANDÃO, Carlos Antônio. Desenvolvimento regional no Brasil: políticas, estratégias e perspectivas. Rio de Janeiro: IPEA, Cap. 9, 2017

VILLAÇA, Flávio José Magalhães. Espaço intra-urbano no Brasil. São Paulo: Studio Nobel, 1998

. O território e a dominação social. In: Revista Margem Esquerda, n. 24, p. 31-36, 2015.

\section{LEGISLAÇÃO:}

SÃO PAULO (Estado). Constituição do Estado de São Paulo. São Paulo, 1989

BRASIL. Lei $\mathrm{n}^{\circ}$ 8.666, de 21 de junho de 1993. Regulamenta o art. 37, inciso XXI, da Constituição Federal, institui normas para licitações e contratos da Administração Pública e dá outras providências. Brasília, DF, jun 1993.

Lei 10.172. Aprova o Plano Nacional de Educação e dá outras providências. Diário Oficial da União, Poder Executivo, Brasília, DF, 9 jan 2001.

- Decreto $\mathrm{n}^{\mathrm{o}} 6.047$ de 22 de fevereiro de 2007. Institui a Política Nacional de Desenvolvimento Regional - PNDR - e dá outras providências. Brasília, DF, fev 2007.

Decreto ${ }^{0}$ 6.094. Estabelece e implementa o Plano de Metas Compromisso Todos Pela Educação. Diário Oficial da União, Brasília, DF, 25 abril 2007.

Decreto n ${ }^{0}$ 6.096. Institui o Programa de Apoio a Planos de Reestruturação e Expansão das Universidades Federais - REUNI. Diário Oficial da União, Brasília, DF, 25 abr 2007.

. Decreto $n^{0}$ 6.755, de 29 de janeiro de 2009. Institui a Política Nacional de Formação de Profissionais do Magistério da Educação Básica, disciplina a atuação da Coordenação de Aperfeiçoamento de Pessoal de Nível Superior -CAPES no fomento a programas de formação inicial e continuada, e dá outras providências. Brasília, DF, jan 2009 
DIADEMA. Lei municipal $\mathrm{n}^{\circ} 2.082$, de 07 de dezembro de 2001. Autoriza o poder executivo a celebrar convênio com a Universidade Federal de São Paulo - Unifesp - e a sociedade paulista para o desenvolvimento da medicina - SPDM - PSF, para prestação de serviços relativos à implantação, coordenação e execução dos programas e ações de saúde no município de diadema, na forma que especifica. Diadema, SP, dez 2001.

. Lei municipal $\mathrm{n}^{\mathrm{o}} 2.191$, de 05 de dezembro de 2002. Autoriza o poder executivo a celebrar convênio com a Universidade Federal de São Paulo - Unifesp e a sociedade paulista para o desenvolvimento da medicina -SPDM - PSF, para prestação de serviços relativos à implantação, coordenação e execução dos programas e ações de saúde no município de diadema, na forma que especifica. Diadema, SP, dez 2002.

. Lei municipal $n^{\circ} 2.463$, de 20 de dezembro de 2005. Autoriza o poder executivo a celebrar convênio de cooperação técnica com a universidade federal de são paulo - UNIFESP, visando o desenvolvimento de ações conjuntas destinadas à promoção de cursos de graduação, pós-graduação e técnicos (seqüenciais) no município, e dá providências correlatas. Diadema, SP, dez 2005.

. Lei municipal $\mathrm{N}^{\mathrm{o}} 2.940$, de 21 de dezembro de 2009. Autoriza o poder executivo a celebrar convênio com a união, representada pelo ministério da educação, por intermédio da coordenação de aperfeiçoamento de pessoal de nível superior (capes) e a Universidade Federal De São Paulo - UNIFESP. Diadema, SP, dez 2009.

Lei municipal $n^{\circ} 2.973$, de 30 de abril de 2010. AUTORIZA o Poder Executivo a celebrar convênio com a Universidade Federal de São Paulo - UNIFESP e dá outras providências. Diadema, SP, abr 2010

. Lei municipal $\mathrm{n}^{\circ} 3.166$, DE 17 de novembro de 2011. ALTERA dispositivo da Lei Municipal $n^{\circ} 2.973$, de 30 de abril de 2010, que autoriza o Poder Executivo a celebrar convênio com a Universidade Federal de São Paulo - UNIFESP e autoriza a celebração de termo de reratificação, na forma que especifica. Diadema, SP, nov 2011.

\section{ATAS}

UNIVERSIDADE FEDERAL DE SÃO PAULO. Ata Conselho Universitário realizado no dia 10 nov 2004. Disponível em $<$ http://www.unifesp.br/images/docs/atas/10-11-04.pdf $>$. Acesso em: 18 dez 2018.

UNIVERSIDADE FEDERAL DE SÃO PAULO. Ata Conselho Universitário realizado no dia 09 mar 2005. Disponível em <http://www.unifesp.br/images/docs/atas/09-03-05.pdf $>$. Acesso em: 18 dez 2018.

UNIVERSIDADE FEDERAL DE SÃO PAULO. Ata Conselho Universitário realizado no dia 12 set 2007. Disponível em <http://www.unifesp.br/images/docs/atas/12-09-07.pdf>. Acesso em: 18 dez 2018. 
UNIVERSIDADE FEDERAL DE SÃO PAULO. Ata Conselho Universitário realizado no dia $12 \mathrm{dez}$ 2005. Disponível em <http://www.unifesp.br/images/docs/atas/14-12-05.pdf>. Acesso em: 18 dez 2018.

UNIVERSIDADE FEDERAL DE SÃO PAULO. Ata Conselho Universitário realizado no dia 12 abr 2006. Disponível em <http://www.unifesp.br/images/docs/atas/12-04-06.pdf > . Acesso em: 18 dez 2018.

UNIVERSIDADE FEDERAL DE SÃO PAULO. Ata Conselho Universitário realizado no dia 10 mar 2010. Disponível em <http://www.unifesp.br/images/docs/atas/10-03-10.pdf $>$. Acesso em: 18 dez 2018.

UNIVERSIDADE FEDERAL DE SÃO PAULO. Ata Congregação do campus Diadema realizada no dia 10 out 2014. Disponível em <https://www.unifesp.br/campus/dia/atasregistradas>. Acesso em: $18 \mathrm{dez} 2018$.

UNIVERSIDADE FEDERAL DE SÃO PAULO. Ata da Congregação do Campus Diadema realizada no dia $18 \mathrm{dez}$ 2014. Disponível em <https://www.unifesp.br/campus/dia/atasregistradas>. Acesso em: $18 \mathrm{dez} 2018$.

UNIVERSIDADE FEDERAL DE SÃO PAULO. Ata da Congregação do Campus Diadema realizada no dia $07 \mathrm{fev}$ 2014. Disponível em <https://www.unifesp.br/campus/dia/atasregistradas>. Acesso em: $18 \mathrm{dez} 2018$.

UNIVERSIDADE FEDERAL DE SÃO PAULO. Ata da Congregação do Campus Diadema realizada no dia 01 set 2016. Disponível em <https://www.unifesp.br/campus/dia/atasregistradas>. Acesso em: $18 \mathrm{dez} 2018$.

\section{OUTROS}

Boletim do Observatório Econômico e do Trabalho de Diadema, 2017. Disponível em $<$ http:// www.diadema.sp.gov.br/dmp/comunicacao/Comunicacao/Site2/BoletimObservatorioAnoIVn7-Maio17.pdf>. Acesso em 03.01.2019.

"O desafio de posicionar o Brasil na rota do desenvolvimento". Disponível em $<$ http://hotsite. fiesp.com.br/downloads/decomtec/20180928/PROJETO-AGENDA-WEB.pdf $>$. Acesso em 03.01 .2019

Research In Brazil. Disponível em: < https://www.capes.gov.br/images/stories/download/ diversos/17012018-CAPES-InCitesReport-Final.pdf>. Acesso em: 03.01.2019 


\section{APÊNDICES}




\section{APÊNDICE A - Enquetes aplicadas com docentes e técnicos-administrativos}

1. Município de residência atual:

2. Bairro de residência atual:

3. Há quanto tempo trabalha no campus Diadema?
a. 1 ano
b. 2 anos
c. 3 anos
d. 4 anos
e. 5 anos
f. 6 anos
g. 7 anos
h. 8 anos
i. 9 anos
j. 10 anos ou mais

4. Em qual unidade do campus passa a maior parte do tempo?
a. Ed. de Vidro
b. Complexo Didático
c. Antônio Doll
d. Florestan Fernandes
e. Oficina Mecânica (Manoel da Nóbrega)
f. José de Filippi

5. Mudou o local de residência para trabalhar no campus Diadema?
a. $\operatorname{sim}$
b. não

6. Caso afirmativo na resposta anterior, indique o bairro e o município anterior de residência (ex. Jabaquara/São Paulo):

7. Se você optou por NÃO se mudar para Diadema, por favor cite alguns dos principais motivos:

8. Se você optou POR SE MUDAR para Diadema, por favor cite alguns dos principais motivos:

9. Qual ou quais os principais meios de locomoção que você utiliza para ir até o campus?
a. metrô
b. ônibus municipal 
c. ônibus intermunicipal (inclusive troileibus)

d. a pé

e. bicicleta

f. carro

g. moto

10. Qual o tempo médio de deslocamento entre a residência e o local de trabalho?

11. Desde que começou a trabalhar no campus Diadema, notou mudanças no entorno de sua unidade? Quais?

12. Há boas opções de restaurantes próximas à sua unidade?

13. Como você avalia a disponibilidade e qualidade dos restaurantes próximos à sua unidade?

13. Há fácil acesso a comércio e serviços variados no entorno de sua unidade?

14. Você avalia que desde que iniciou seus trabalhos no campus houve mudanças significativas na oferta de comércio e serviços?

15. Há boas opções de lazer e cultura em Diadema? Você as aproveita?

16. Você faz parte de algum grupo político, conselho ou similar situado em Diadema?

17. Em caso afirmativo na última resposta, descreva brevemente sobre o que se trata. Sua atuação representa o campus Diadema? 


\section{APRÊNDICE B - E-mail padrão enviado aos docentes para entrevistas não presenciais.}

\section{Bom dia, Professora/Professor}

Estou cursando mestrado pela Faculdade de Arquitetura e Urbanismo da Universidade de São Paulo e realizo uma pesquisa sobre o campus Diadema da Unifesp, procurando saber de que formas o campus tem participado e colaborado para o processo de desenvolvimento urbano e regional.

Gostaria de convidá-la a participar da pesquisa através de uma entrevista. As perguntas que nortearão a entrevista são as que seguem e você pode optar por respondê-las por e-mail ou, se preferir, presencialmente com entrevista gravada.

O termo de consentimento está em anexo e eu me comprometo a ir coletar sua assinatura no campus em breve. No termo há uma opção para escolher sua preferência por possibilitar que eu a identifique na redação da pesquisa ou não.

Seguem as questões:

1. Qual o foco da sua pesquisa na universidade?

2. Há empresas ou indústrias que já manifestaram interesse nas pesquisas do seu laboratório? Alguma parceria chegou a ser firmada?

3. Caso haja ou tenha havido parceria com empresas ou indústrias, você pode detalhar quais os objetivos da parceria? Qual a responsabilidade da empresa? E da universidade?

4. Houve interesse ou envolvimento com algum órgão ou repartição pública? Em que sentido?

Por enquanto são essas as dúvidas.

Agradeço desde já,

Alex Sartori 